\title{
Educação inclusiva, deficiência e contexto social:
}

questões contemporâneas

Félix Díaz

Miguel Bordas

Nelma Galvão

Theresinha Miranda

Orgs.

DÍAZ, F., et al., orgs. Educação inclusiva, deficiência e contexto social: questões contemporâneas [online]. Salvador: EDUFBA, 2009. 354 p. ISBN: 978-85-232-0651-2. Available from SciELO Books $<\underline{\text { http://books.scielo.org }>\text {. }}$

\section{cc) $\$(0)$ \\ BY NC SA}

All the contents of this work, except where otherwise noted, is licensed under a Creative Commons Attribution-Non Commercial-ShareAlike 3.0 Unported.

Todo o conteúdo deste trabalho, exceto quando houver ressalva, é publicado sob a licença Creative Commons Atribuição Uso Não Comercial - Partilha nos Mesmos Termos 3.0 Não adaptada.

Todo el contenido de esta obra, excepto donde se indique lo contrario, está bajo licencia de la licencia Creative Commons Reconocimento-NoComercial-CompartirIgual 3.0 Unported. 


\section{EDUCAÇÃO INCLUSIVA, DEFICIÊNCIA E CONTEXTO SOCIAL: questões contemporâneas}




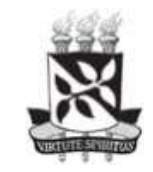

UNIVERSIDADE FEDERAL DA BAHIA

Reitor

Naomar Monteiro de Almeida Filho

Vice-Reitor

Francisco José Gomes Mesquita

\section{EDITORA DA UNIVERSIDADE FEDERAL DA BAHIA}

\section{Diretora}

Flávia Goullart Mota Garcia Rosa

\section{Conselho Editorial}

Titulares

Ângelo Szaniecki Perret Serpa

Caiuby Alves da Costa

Charbel Ninõ El-Hani

Dante Eustachio Lucchesi Ramacciotti

José Teixeira Cavalcante Filho

Alberto Brum Novaes

\section{Suplentes}

Antônio Fernando Guerreiro de Freitas

Evelina de Carvalho Sá Hoisel

Cleise Furtado Mendes

Maria Vidal de Negreiros Camargo 
FÉLIX DÍAZ

MIGUEL BORDAS

NELMA GALVÃO

THERESINHA MIRANDA

(Organizadores)

\section{EDUCAÇÃO INCLUSIVA, DEFICIÊNCIA E CONTEXTO SOCIAL: questões contemporâneas}


(C)2009 by Organizadores

Direitos de edição cedidos à

Editora da Universidade Federal da Bahia - EDUFBA

Feito o depósito legal

Revisão de linguagem

Susane Barros

Editoração eletrônica e capa

Rodrigo Oyarzábal Schlabitz

Assessoria técnica da Edufba - UFBA

Educação inclusiva, deficiência e contexto social: questões contemporâneas/ Féliz Díaz,

Miguel Bordas, Nelma Galvão, Theresinha Miranda, organizadores; autores, Elias Souza dos Santos... [et al.]. - Salvador: EDUFBA, 2009.

$354 \mathrm{p}$.

ISBN: 978-85-232-0651-2

1. Educação inclusiva - aspectos sociais. 2. Inclusão social. 3. Igualdade social. 4. Crianças deficientes - Educação - aspectos sociais. 5. Crianças com distúrbios de aprendizagem - Educação - aspectos sociais. I. Diaz, Feliz. II. Bordas, Miguel. III. Galvão, Nelma. IV. Miranda, Theresinha. V. Santos, Elias Souza dos.

\section{eref} de América Latina y el Caribe

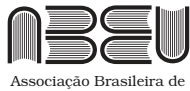

Associação Brasileira de
Editoras Universitárias
$\mathrm{CBaL}$

EDUFBA

Rua Barão de Jeremoabo, s/n - Campus de Ondina,

40170-115 Salvador-BA

Tel/fax: (71) 3283-6164

www.edufba.ufba.br

edufba@ufba.br 


\section{SUMÁRIO}

\section{9 / PREFÁCIO}

\section{CULTURA ESCOLAR E INCLUSÃO}

15 / COMUNIDADE SURDA: a questão de suas identidades

Elias Souza dos Santos

27 / A INCLUSÃO DE ALUNOS COM DEFICIÊNCIA NO ENSINO SUPERIOR: uma análise de seu acesso e permanência

Telma Brito Rocha

Theresinha Guimarães Miranda

39 / REFLEXÕES SOBRE A INCLUSÃO LINGUÍSTICA NO CONTEXTO ESCOLAR

Iara Rosa Farias

Antonio Fernando Santos

Érica Bastos da Silva

49 / A PERCEPÇÃO DA TRIBO INDÍGENA PANKARARÉ SOBRE O ÍNDIO COM DEFICIÊNCIA VISUAL

Patrícia Carla da Hora Correia

Daniela Fernanda da Hora Correia

61 / COMPREENDENDO O TERRITÓRIO-LUGAR COMO PONTO DE PARTIDA PARA A INCLUSÃO SOCIAL

Cleverson Suzart

Fernanda Ma Gonçalves Almeida

Mary Arapiraca

Miguel Angel Garcia Bordas

71 / CONVIVENDO COM DIVERSIDADE: a inclusão escolar da criança com deficiência intelectual

Cristiane Teixeira Sampaio

Sônia Maria Rocha Sampaio

79 / REFLEXÕES SOBRE A PRODUÇÃO SOCIAL DO CONHECIMENTO E AS CULTURAS INCLUSIVAS: o papel da avaliação

Miguel Angel Garcia Bordas

Fabio Zoboli 


\section{PRÁTICAS PEDAGÓGICAS INCLUSIVAS}

91 / INCLUSÃO ESCOLAR EM FEIRA DE SANTANA: caracterização da prática pedagógica

Gilianderson Freitas Ribeiro

Tânia de Souza Lima

Marilda Carneiro Santos

99 / MATERIAIS DIDÁTICOS ALTERNATIVOS PARA O ENSINO DE CIÊNCIAS A ALUNOS COM DEFICIÊNCIA VISUAL

Renata Barbosa Gonçalves

Carlos Alberto Fonseca Jardim Vianna

Sirley Brandão dos Santos

107 / EXCLUSÃO DAS CRIANÇAS CEGAS DA PRÁTICA DE ENSINO DA ALFABETIZAÇÃO ESPACIAL EM UM CONTEXTO DE ESCOLA INCLUSIVA Marcelo Torreão Sá

117 / CONSCIÊNCIA FONOLÓGICA E SISTEMA BRAILE: reflexões sobre o tratamento da ortografia

Iara Rosa Farias

Amanda Ribeiro Botelho

127 / A INSTITUCIONALIZAÇÃO DO SOROBAN NA ESCOLA E A GÊNESE INSTRUMENTAL POR APRENDIZES CEGOS

Aida Carvalbo Vita

Afonso Henriques

Irene Maurício Cazorla

137 / REPRESENTAÇÕES CONCEITUAIS NA PRÁTICA EDUCATIVA ESPECIAL E INCLUSIVA DO PROFESSOR DE EDUCAÇÃO FÍSICA

Chrystiane Vasconcelos Andrade Toscano

Rita de Cácia Santos Souza

\section{ABORDAGEM MULTIDIMENSIONAL}

149 / FAMÍLIA E ESCOLA: como essa parceria pode favorecer crianças com necessidades educativas especiais

Cláudia Paranhos de Jesus Portela

Célia Verônica Paranhos de Jesus Portela

161 / ESTRATÉGIA DE SAÚDE DA FAMÍLIA NO PROCESSO DE INCLUSÃO REINSERÇÃO DO ESCOLAR PÓS-HOSPITALIZADO

Jamine Barros Oliveira

Maria Celeste Ramos da Silva

Nayara Alves de Sousa 
171 / AS CONTRIBUIÇÕES DA PSICOLOGIA NA EDUCAÇÃO DE SURDOS: o caso do Centro de Educação Especial do Estado da Bahia

Silvana Correia Silva

Antonieta Araújo

Marilda Castelar

Nicoleta Mendes

191 / ACESSIBILIDADE TECNOLÓGICA

Teófilo Alves Galvão Filho

203 / SEXUALIDADE DE ADOLESCENTES PORTADORES DE DIFERENTES DEFICIÊNCIAS

Fernanda Nunes Macedo

Elaine Pereira Terrassi

211 / CORPO E ALTERIDADE NOS COMPLEXOS DE (IN)EXCLUSÃO

Fabio Zoboli

Renato Izidoro da Silva

Miguel Angel Garcia Bordas

\section{ATENDIMENTO EDUCACIONAL ESPECÍFICO}

225 / AUTISMO: uma abordagem tamanho família

Mariene Martins Maciel

Argemiro de Paula Garcia Filho

237 / DEFICIÊNCIA MENTAL, APRENDIZAGEM E DESENVOLVIMENTO

Evanir Abenhaim

245 / O FAZER PEDAGÓGICO DIANTE DO TRANSTORNO DE DÉFICIT DE ATENÇÃO E HIPERATIVIDADE NO CONTEXTO ESCOLAR

Diana Maria Pereira Cardoso

255 / DEFICIÊNCIA VISUAL E SURDOCEGUEIRA

Miralva Jesus dos Santos

Nelma de Cássia Silva Sandes Galvão

Sheila Correia de Araújo

265 / ALGUMAS CONSIDERAÇÕES SOBRE OS CHAMADOS TRANSTORNOS COMPORTAMENTAIS

Felix Dias Rodríguez

279 / PANORAMA DA CLASSE HOSPITALAR NO MUNDO

Alessandra Barros

289 / A EDUCAÇÃO PROFISSIONAL: interfaces com a educação especial Eliane Sousa Nascimento 
303 / SÍNDROME DE DOWN: desafios e perspectivas na inclusão escolar Antonilma Santos Almeida Castro

Susana Couto Pimentel

\section{GESTÃO ESCOLAR}

315 / COORDENAÇÃO PEDAGÓGICA E MEDIAÇÃO TECNOLÓGICA INTERFACE NA PERSPECTIVA DE UMA EDUCAÇÃO INCLUSIVA

Andréa Direne da Matta Castro

Leliana de Sousa Gauthier

323 / "OLHAR" DE GESTORES SOBRE A INCLUSÃO DE PESSOAS COM DEFICIÊNCIA EM ESCOLAS REGULARES NO VALE DO JIQUIRIÇÁ

Susana Couto Pimentel

Livia Menezes da Paz

333 / ORIENTAÇÕES PARA O PLANEJAMENTO DE ENSINO-APRENDIZADO DA NATAÇÃO PARA CRIANÇAS NA PERSPECTIVA DA INCLUSÃO

Suzana Alves Nogueira

Gilmar Mercês de Jesus

João Danilo Batista de Oliveira

Admilson Santos

Sandra Regina Rosa Farias

347 / A FORMAÇÃO CONTINUADA DO PROFESSOR DE ARTE NA PERSPECTIVA DE UMA EDUCAÇÃO INCLUSIVA

Roberto Sanches Rabêllo

357 / SOBRE OS AUTORES 


\section{PREFÁCIO}

Este livro contém os trabalhos apresentados e discutidos durante a realização do I Congresso Baiano de Educação Inclusiva: a deficiência como produção social, que teve como objetivo discutir as relações sociais e suas implicações no processo de desenvolvimento da pessoa com deficiência. Esse enfoque decorre da relevância de que o contexto sociocultural em que a pessoa está inserida serve de parâmetro para classificá-la como normal e anormal e enfatiza o ensino e a escola, bem como as formas e condições de aprendizagem. Essa perspectiva, em vez de procurar, no aluno, a origem de um problema, define o tipo de resposta educativa e de recursos e apoios que a escola deve proporcionar a esse aluno, para que obtenha sucesso escolar. Por fim, em vez de pressupor que o aluno deve ajustar-se a padrões de "normalidade" para aprender, aponta para a escola o desafio de ajustar-se para atender à diversidade de seus alunos.

Em síntese, o desenvolvimento da pessoa não pode ser considerado como um dado biológico isolado, mas sim culturalmente delineado. Nesse particular, o modelo social, ao contrário do modelo clínico, ${ }^{1}$ tradicional e classificatório, enfatiza o papel do contexto social para o desenvolvimento e a aprendizagem do aluno, e, consequentemente, requer a melhoria da instituição escolar, para que identifique as potencialidades e necessidades educacionais dos alunos e ofereça respostas educativas adequadas a essas necessidades.

\footnotetext{
${ }^{1}$ Abordagem médica e psicológica, que se detinha no que pretensamente "faltava" aos educandos. Implicava um diagnóstico clínico, para avaliar as características e dificuldades manifestadas pelos alunos, objetivando constatar se deviam, ou não, ser encaminhados às classes especiais ou escolas especiais ou ainda às classes comuns do ensino regular.
} 
Ao considerar esse modelo, o foco deve ser a eliminação das barreiras didáticas, arquitetônicas e sociais que não estão, necessariamente, relacionadas à deficiência, mas às condições do ambiente, aos preconceitos, estereótipos e discriminações. Nesse enfoque, surge a educação inclusiva que tem provocado um complexo e paradoxal movimento de ideias e debates acerca dos discursos, das práticas e processos sobre a educação das pessoas com necessidades especiais, que tem tomado significativas dimensões em espaços institucionais, sociais e midiáticos.

Os textos reunidos neste livro tratam de vários aspectos do contexto escolar e social no qual se desenvolvem práticas e valores em que a diferença é encarada como uma condição humana. Para isso, é necessário a desconstrução de velhos valores tipológicos e uma abertura à mudança. Os autores apresentam estudos e experiências que contribuem para a problematização e o delineamento de perspectivas aos desafios colocados para a educação pública, democrática e de qualidade para todos e exploram de diferentes ângulos as implicações de pesquisas e de práticas direcionadas às pessoas com deficiência e interpretadas a partir do cenário político-econômico atual.

A discussão sobre educação inclusiva envolve a relação exclusão e inclusão que ganha tonalidades diferentes e altera as políticas sociais, impondo uma nova ética e uma moral que justificam o controle das tecnologias, o monopólio das riquezas, o domínio das informações, a circulação de conhecimento, a seleção dos benefícios, a delimitação dos territórios e as possibilidades de melhorias de vida.

Debater e refletir sobre diferentes formas de organização escolar e social para acolher a diversidade humana não é tarefa simples, não significa, apenas, arrolar um conjunto de situações em que os segmentos excluídos da sociedade, por exemplo, têm seus direitos usurpados. As injustiças sociais demonstram que mais do que ser diferente, o que coloca este ser humano em uma condição de desvalorização é ser um diferente que possui "menos valia" no mundo capitalista, onde a valorização de uns em detrimento de outros, expressa valores que impõem uma nova ordem de relações sociais produtivas, que alteram a forma de ser do outro, colocando-o na condição de não-humano, ou melhor, de um cidadão ou cidadã de segunda categoria.

Nessa linha de pensamento, os artigos deste livro expressam, não somente, o quadro atual no qual as pessoas com deficiência se encontram, mas também trazem à tona elementos importantes sobre a educação dessas pessoas. A obra organiza-se em torno de cinco eixos: cultura escolar; práticas pedagógicas; abordagem multidimensional, atendimento educacional específico e processos de gestão escolar. 
O tema cultura escolar apresenta múltiplos olhares sobre as práticas com distintos grupos e com relações evidentes às diferentes experiências, o que leva a refletir sobre as ambiguidades dessas práticas e discute a perspectiva do desenvolvimento pessoal que a educação implica.

O segundo eixo trata das práticas pedagógicas apresentando textos com um forte componente empírico, refletindo sobre alguns dilemas da educação, como: a implementação das políticas de inclusão, o funcionamento e a organização de escolas e propostas metodológicas de atuação docente.

$\mathrm{Na}$ mesma linha e com textos muito ricos pelas formulações que apresentam e pelas questões que levantam, os artigos que compõem o subtema abordagem multidimensional discutem o contexto familiar e a relação com a escola, o papel da área da saúde nesse processo, e das áreas da Psicologia, da Tecnologia, da Educação Física e da Sexualidade. Essa discussão abrange algumas das dimensões que interferem no processo educacional e que podem favorecer o sucesso da inclusão escolar.

O quarto eixo trata dos educandos que apresentam necessidades especiais e requerem atenção educacional específica durante o processo educacional e demonstram dificuldades acentuadas de aprendizagem ou limitação no processo de desenvolvimento que dificultam o acompanhamento das atividades curriculares. Nessa perspectiva, os artigos apresentam estudos e experiências que relatam propostas educativas para atender a diferentes necessidades especiais.

E, por último, encontram-se estudos que discutem os processos de organização e gestão escolar, que têm um grande impacto na planificação e implementação das políticas públicas de inclusão, nas atividades acadêmicas e na qualidade e diferenciação dos processos inclusivos dos alunos.

Como conclusão, ressalta-se que está em questão a necessidade dos sistemas de ensino instituírem um ordenamento político-jurídico que configure o projeto político educacional numa perspectiva inclusiva. Isso porque aos sistemas de ensino compete formular políticas claras e decisivas em relação à inclusão, buscando aperfeiçoar os recursos da Educação Especial e da Educação em geral para dotar as escolas de infraestrutura, equipamentos e recursos materiais e didático-pedagógicos, necessários ao bom desenvolvimento das atividades escolares.

Este livro pretende oferecer uma contribuição para o debate das questões que permeiam a educação inclusiva e para que os leitores possam apro- 
veitar os textos como uma peça na construção de práticas e valores de uma escola que respeite as diferenças e colabore na melhoria da qualidade da educação brasileira.

Os organizadores 


\section{CULTURA ESCOLAR E INCLUSÃO}





\section{COMUNIDADE SURDA:}

\section{a questão das suas identidades}

Elias Souza dos Santos

\section{INTRODUÇÃO}

Este estudo constitui-se numa das primeiras investigações, enquanto pedagogo e pai de uma adolescente surda. O propósito do trabalho é buscar entender as identidades surdas e lançar olhares que venham contribuir para a formação de novas posturas no campo educacional, social e cultural. O buscar, o compreender e o elucidar são passos relevantes para entendermos as identidades surdas e seu universo. Acreditamos que as discussões atuais sobre os sujeitos surdos estão avançando e possibilitando uma reconstrução do campo educacional dos não ouvintes.

Nesse sentido, convém comentar sobre o conceito da palavra surdez. Lima e Vieira (2006, p. 52-53), no excerto abaixo, conceituam a surdez como sendo:

[...] a perda total ou parcial, congênita ou adquirida, da capacidade de compreender a fala por intermédio do ouvido. [...] Simplificando bastante, podemos dizer que recebemos as informações, difundidas pelo canal auditivo, por meio das palavras, e assim aprendemos a falar. A pessoa surda não recebe essas e outras informações auditivas da mesma forma que a maioria.

As argumentações das autoras citadas contribuem para que tenhamos uma melhor compreensão do universo das pessoas surdas. Elas prosseguem afirmando que: 
[...] a criança surda congênita, quando bebê, emite os mesmos sons que as crianças ouvintes. Porém, como não escuta os próprios gorjeios, eles se extinguem. Isso significa que a criança surda não é necessariamente muda, pois seus órgãos fonadores permanecem intactos. Ela não aprende a falar porque não ouve. Ainda hoje ouvimos a expressão "surdo-mudo", como referência à pessoa surda, o que é um equívoco, pois ela pode não ser muda e adquirir a linguagem. (LIMA; VEIRA, 2006, p. 55).

O presente trabalho caracteriza-se, metodologicamente como sendo uma pesquisa bibliográfica. A pesquisa bibliográfica, de acordo com Prestes (2003), é aquela que serve tanto ao acadêmico, na sua graduação, quanto aos pesquisadores, na elucidação dos trabalhos inéditos que pretendem rever, re-analisar, interpretar e criticar considerações teóricas ou paradigmas, ou ainda criar novos teoremas, com o objetivo de tentar compreender os fenômenos das mais diversas áreas do conhecimento.

Para a explanação desse tema, buscamos apoio nos estudos produzidos por Lima e Vieira (2006), Perlin (1998), Pinto (2007), Quadros (1997), Sá (2002), Skiliar (1998) e Soares e Lacerda (2004).

As discussões aqui apresentadas estão norteadas pelas seguintes concepções teórico-metodológicas: os Estudos Culturais e os Estudos Surdos. Os Estudos Culturais são parte de "um campo de estudos em que diversas disciplinas se interseccionam no estudo de aspectos culturais da sociedade contemporânea, constituindo um trabalho historicamente determinado” (ESCOSTEGUY, [2001?]).

Sá (2002) se apropria dos autores dos Estudos Culturais para nos esclarecer sobre as identidades surdas. Para a autora,

[...] os Estudos Culturais, então, inscrevem-se na luta para que todas as culturas venham a ser consideradas na rede social. Para que isto seja possível, uma das áreas de maior conflito/interesse é a área da educação, por seu poder constituidor de subjetividades. Assim, os Estudos Culturais envolvem uma educação multicultural. [...] Os Estudos Surdos se incluem entre os temas multiculturalistas. (SÁ, 2002, p. 74).

Os Estudos Culturais nos levam a ver o surdo com um olhar humanístico, ou seja, o olhar do sociólogo. O Multiculturalismo é um movimento que combate as manifestações que defendem uma sociedade homogênea. Tem como meta o respeito às diferentes classes sociais existentes em uma sociedade. 
As abordagens defendidas pelos autores citados nos ajudarão a compreender melhor o mundo do outro surdo, o não ouvinte, aquele que ouve com os olhos e fala através das mãos.

\section{AS IDENTIDADES DOS SUJEITOS SURDOS}

O conceito de identidade é muito amplo e assume conotações e interpretações diferenciadas e bastante complexas, pois tem sido alvo de discussão das várias áreas do conhecimento. No dicionário Universal da Língua Portuguesa, descobrimos que a palavra identidade vem do latim identitade e significa "a qualidade do que é idêntico; paridade absoluta; analogia; conjunto de elementos que permitem saber quem uma pessoa é." (DICIONÀRIO..., 2007).

Considerando que o tema em evidência é relevante para entender o sujeito surdo (a sua educação e a sua cultura), é praticamente impossível falarmos de surdos sem abordarmos a questão das identidades deles. Falar destas identidades é estar diante de um mundo extremamente complexo. Nesse sentido, optamos por expor as definições dos autores que escreveram sobre as identidades dos sujeitos surdos.

De acordo com Hall (apud PERLIN, 1998) existem três conceitos diferenciados sobre o termo identidade: o iluminista, o sociológico e o da modernidade tardia. O iluminista é voltado exclusivamente para o homem perfeito, já o sociológico percebe que as identidades se modelam, conforme as representações sociais e o da modernidade tardia, afirma que as identidades são fragmentadas. Neste caso, no que se refere ao sujeito surdo, percebemos que este último conceito de identidades, o da modernidade tardia, é o mais interessante para situá-lo.

De acordo com Perlin (1998), dentro de uma comunidade social não existe apenas uma única identidade. Como somos plurais, esse processo constitui-se como sendo dinâmico, pois à medida que o sujeito vai se estruturando dentro do seu grupo, também vai assumindo ou rejeitando algumas características impostas pelo sistema a que pertence. Mas, o interessante disso tudo é que a identidade está sempre em processo de formação ou transformação.

Quanto à identidade surda, conforme ressalta Perlin (1998, p. 53),

dentro da cultura ouvinte é um caso onde a identidade é reprimida, se rebela e se afirma em questão da original. A identidade original estabelece uma identidade de subordinação em vista da alteridade cultural, a mesma que se dá entre outros grupos étnicos. 
Por ser uma autora surda não nativa, percebemos que seu posicionamento a respeito do ouvintismo ${ }^{1}$ é extremamente crítico. Esta ideologia tem trabalhado para o extermínio do surdismo.

Para a autora comentada, os sujeitos surdos vivem em uma situação de marginalização. Criaram-se estereótipos que reforçam as visões negativas dos ouvintes. "O surdo foi acumulando estereótipos que têm reforçado cada vez mais a hegemonia discriminatória de sua produção cultural. O discurso do poder ouvinte mantém-se firme e controla estes estereótipos.” (PERLIN, 1998, p. 55).

Um exemplo dessa visão simbólica estereotipada está presente no mercado de trabalho. Normalmente os sujeitos surdos ocupam função profissional de subordinação. Em Aracaju/SE, percebe-se que a maioria dos surdos trabalha de empacotador nos supermercados, embalador de presentes, serviços gerais, padeiro, carpinteiro, lavador de carro, estofador, dentre outras. São raros os casos em que as pessoas surdas assumem uma função de liderança. Desta forma, os ouvintes criam visões estereotipadas que discriminam e subestimam a capacidade dos sujeitos surdos.

Fazendo uma leitura dos textos que versam sobre as identidades das pessoas surdas, percebemos que Perlin (1998, p. 62-63) as classificam com mais propriedade. Para a autora, as identidades surdas,

[...] estão presentes no grupo onde entram os surdos que fazem uso com experiência visual propriamente dita. Noto nesses surdos formas muito diversificadas de usar a comunicação visual. No entanto, o uso da comunicação visual caracteriza o grupo levando para o centro do específico surdo. [...] Este tipo de identidade surda recria a cultura visual, reclamando à história a alteridade surda.

Então, Perlin classifica as identidades surdas da seguinte forma: identidades surdas híbridas, identidade surda de transição, identidade surda incompleta e identidade surda flutuante. As identidades surdas híbridas referem-se aos ouvintes que por algum motivo (enfermidade, acidentes, entre outros) perderam a audição e se apropriam da Língua de Sinais para se comunicar. "Eles captam do

\footnotetext{
${ }^{1}$ Ouvintismo é "um conjunto de representações dos ouvintes, a partir do qual o surdo está obrigado a olhar-se e a narrar-se como se fosse ouvinte. Além disso, é nesse olhar-se, e nesse narrar-se que acontecem as percepções do ser 'deficiente', do não ser ouvinte; percepções que legitimam as práticas terapêuticas habituais.” (SKILIAR, 1998, p. 15).
} 
exterior a comunicação de forma visual, passam-na para a língua que adquiriram por primeiro e depois para os sinais." (PERLIN, 1998, p. 63). Na verdade o ex-ouvinte assume duas línguas, porém ele se identificará mais precisamente com a comunidade dos sujeitos surdos.

As identidades surdas de transição estão presentes na maioria dos casos de surdos filhos de ouvintes. Eles cresceram com a ideia da oralização ou do ouvintismo, justamente por causa dos familiares ouvintes, depois tiveram a experiência da Língua de Sinais. O momento de transição acontece aí, eles aos poucos vão se identificando com a comunidade surda, mas "embora passando por essa des-ouvintização, os surdos ficam com seqüelas da representação que são evidenciadas em sua identidade em reconstrução nas diferentes etapas da vida." (PERLIN, 1998, p. 64). Esse tipo de identidade pode ser confirmado a partir de experiências pessoais enquanto pai de uma adolescente surda, de forma que toda essa problemática que envolve a educação deles é vivenciada: a cultura, a educação e as identidades surdas. Por um longo período, acreditamos que a nossa filha poderia ser uma ouvinte e oralizada. Com o tempo, a gente percebe que essa concepção acaba prejudicando o desenvolvimento dos sujeitos surdos, pois eles são impedidos dentro da sua própria família de aprenderem na sua língua materna, a Língua Brasileira de Sinais (Libras).

Os surdos que vivem sob o comando de uma ideologia ouvintista latente, normalmente possuem uma identidade surda incompleta. Unem-se aos ouvintes para socializar os demais surdos, de modo que sejam iguais à cultura hegemônica. Vale citar um trecho de uma pesquisa de Perlin. Trata-se de um depoimento de uma estudante surda de 25 anos de idade, com o curso médio completo.

Tenho uma amiga que não procuro muito. Tem alguns restos auditivos. Usa aparelho de audição. Ela não se aceita surda. Ela não quer estar no mundo dos surdos e tudo faz para ser oralizada. Tem poucos amigos. Quando ela foi para o II Grau não gostava de minha LIBRAS, me pedia para falar, o que jamais consenti. Notei que já nos primeiros dias fez amizade com uma colega. Elas ficavam juntas e conversavam, mas isso não durou muito, pois a colega ouvinte deixou-a por outra. Dessa vez sentiu-se desanimada com a experiência. A colega não entendia bem a fala e ela não conseguia compreender bem a colega. Na verdade minha amiga não tem boa voz, é uma voz muito mal articulada porque a colega ouve mal. Ela também não conhece sinais. A 
sua vida parece oscilar como um pêndulo entre surdos e ouvintes, não consegue ter amigos. (PERLIN, 1998, p.75).

O problema é muito mais grave do que nós imaginamos. A questão da identidade no sujeito, seja ele qual for, repercute diretamente no seu comportamento social. No caso da identidade surda de transição, de acordo com o depoimento, observou-se que a surda incompleta ficou praticamente sem ter onde se amparar. Na qualidade de pai, esse depoimento contribui para que assuma uma postura pela qual venha trabalhar e lutar, com o objetivo de oferecer aos sujeitos surdos todas as possibilidades de se encontrarem e identificarem no grupo que pertence. Perlin (1998, p. 75$)$ prossegue afirmando que

há casos de surdos cujas identidades foram escondidas, nunca puderam encontrar-se com outros surdos, conseguiram adentrarse no saber junto aos ouvintes e há casos de surdos mantidos em cativeiros pela família onde se tornam incapacitados de chegar ao saber ou de se decidirem por si mesmos.

Identidades surdas flutuantes têm a ver com os surdos que apresentam um posicionamento consciente de ser ou não ser surdo.

São muitos os casos e muitas as histórias de surdos profissionalizados que vivem as identidades flutuantes, pois não conseguiram estar a serviço da comunidade ouvinte por falta de comunicação e nem a serviço da comunidade surda por falta da língua de sinais. É o sujeito surdo construindo sua identidade com fragmentos das múltiplas identidades de nosso tempo, não centradas, fragmentadas. (PERLIN, 1998, p. 66).

Por conta das relações de poder, a comunidade surda, por um longo período, ficou silenciada, sua identidade foi massacrada. Mas, devido ao fracasso das tendências teórico-metodológicas que tentaram e tentam privilegiar o oralismo, os próprios surdos se viram obrigados a irem à luta. Alguns estudos, a respeito da educação dos surdos, partiram justamente de pais e filhos de surdos, ou dos próprios surdos. Temos o exemplo da própria Gládis Perlin (surda não nativa), de Patrícia Pinto (surda não nativa), de Ronice Quadros (filha de pais surdos) e de Nídia de Sá (mãe de uma jovem surda). Esta última afirma que "os surdos e a comunidade surda são plurais, como o é todo o agrupamento humano. Toda a identidade é dinâmica e é transformada continuamente". (SÁ, 2002, p.101) 
A partir dessa iniciativa, outros olhares começaram a ser lançados sobre a comunidade surda. Esses estudos

estão situando-se atualmente na direção de outras linhas de estudo como: os estudos negros, os estudos de gênero, os estudos de classes populares, etc. Isto inclui a educação de surdos num contexto discursivo mais apropriado à situação lingüística, social, comunitária, cultural e identitária das pessoas surdas. (SÁ, 2002, p. 71).

Para Skiliar (1998), as crianças surdas têm uma facilidade natural de desenvolver-se na língua de sinais. Comunicar-se e construir conhecimento em Libras, para a criança surda, é igual a se comunicar e construir conhecimentos em português, para as crianças ouvintes. Assim, convém entender que as pessoas surdas:

[...] têm o direito de se desenvolverem numa comunidade de pares, e de construírem estratégias de identificação no marco de um processo sócio-histórico não fragmentado, nem cercado. Mas, não estou simplesmente mencionando o processo individual ou a individualização de identificações, como se elas fossem homogêneas, estáveis, fixas, como se a identificação entre os surdos ocorresse de forma inevitável, uma vez que a 'surdez os identifica'. Refiro-me, sim, a uma política de identidades surdas, onde questão ligadas à raça, à etnia, ao gênero, etc., sejam também entendidas como "identidades surdas"; identidades que são, necessariamente, híbridas e estão em constante processo de transição. (SKILIAR, 1998, p. 27).

Soares e Lacerda (2004), numa pesquisa sobre a inclusão de criança surda na escola regular, afirmam que "o modo como a escola está organizada pedagogicamente não leva em conta a surdez e sua complexidade, não atendendo, assim, às necessidades dos surdos." (SOARES; LACERDA, 2004, p.129). As autoras comentam sobre a importância de se considerar a língua materna do sujeito surdo, a Libras. Elas apontam falhas na escola que pretende incluir o surdo no meio dos ouvintes e chegaram à seguinte conclusão:

A inclusão almejada acaba ficando somente nos desejos da escola/ professora, porque há uma organização que implícita ou explicitamente valoriza o ouvir, o ser ouvinte, e isso acaba aparecendo e 
marcando as relações, revelando uma práxis pouco ou nada inclusiva. Nesse constante jogo, constrói identidades que se sucedem e se antagonizam, indicando os efeitos desse ambiente em sua constituição. Mas quais identidades poderão ser construídas neste contexto? (SOARES; LACERDA, 2004, p. 141).

É muito complicada essa questão da inclusão dos sujeitos surdos. O maior impasse é que nesse contexto, os alunos surdos não poderão construir sua identidade porque eles estão no meio de colegas ouvintes, diretores ouvintes, coordenadores ouvintes e professores ouvintes. Como fica a construção da identidade surda no espaço da escola? "A constituição dos sujeitos surdos poderá fluir a partir das relações surdo-surdo, surdo-ouvinte, quando possibilidades que incluam a condição cultural de pessoa surda”. (SOARES; LACERDA, 2004, p. 145).

Para Perlin (1998), a educação precisa desconstruir os vários preconceitos instituídos pelo império do oralismo. Não é justo querer que o surdo seja um ouvinte, o surdo é um sujeito surdo e a escola precisa entender essa questão que envolve a cultura e identidade surda. Uma alternativa apontada pela autora é a inclusão de professores surdos na escola.

Falando como pai de uma adolescente surda, acreditamos que nesse processo de reconhecimento das identidades surdas e reconstrução da educação dos sujeitos surdos, o ideal seria uma escola específica para os surdos. Lutamos durante 11 anos tentando incluir nossa filha na escola pública. Não entendíamos esse processo de reconhecimento do mundo surdo, achávamos que ela tinha possibilidade de aprender junto aos ouvintes. Mas, conforme os anos passavam, fomos nos convencendo de que o lugar dela era junto aos seus semelhantes, aqueles que falavam a mesma língua. Portanto, vale ressaltar a argumentação de Sá (2002, p. 103), quando diz que:

[...] os processos identificatórios da criança surda, então, começam na interação com outros surdos: neste relacionamento, a criança surda pode não apenas adquirir de modo natural a língua de sinais, mas também pode assumir padrões de conduta e valores da cultura e da comunidade surda. Tendo essa possibilidade a criança surda pode absorver não o modelo que a sociedade ouvinte tem para os surdos, mas o que os surdos têm a respeito de si mesmos (este é o principal benefício da experiência comunitária da surdez através da vida escolar precoce: a possibilidade de construção de sua identidade). 
Em Aracaju/SE, vários pais de surdos se uniram para criar a escola que atendesse as necessidades dos seus filhos. $\mathrm{O}$ não atendimento da escola dita regular aos sujeitos surdos fez com que uma escola para surdos surgisse. $\mathrm{O}$ Instituto Pedagógico de Apoio à Educação dos Surdos de Sergipe (Ipaese) é a única escola no Estado que procura desenvolver uma metodologia de ensino específica para os surdos. Em um ano de aula nessa instituição, nossa filha alcançou um desenvolvimento no ensino-aprendizagem de $80 \%$. Na verdade, nesse ambiente educacional, ela se encontrou, pois seus pares falam a Libras.

Sá (2002, p. 75) reconhece que

é perfeitamente viável e desejável optar-se pela criação de escolas específicas para as minorias, na medida em que isto a elas interessem, para atender ao preceito institucional segundo o qual participar de um processo educacional é um direito ao qual devem ter acesso todas às pessoas.

\section{CONSIDERAÇÕES FINAIS}

A sociedade, no decorrer desses séculos, criou estereótipo e estigmatizou os sujeitos surdos. Isso levou a classe hegemônica, os ouvintes, a pensar e decidir por eles. Tudo começou na Itália, no Congresso de Milão, no ano de 1880. Nesse evento os ouvintes, aliados à visão terapêutica da medicina, decidiram proibir os surdos a sinalizarem. Conforme a decisão da maioria ouvinte, os surdos deveriam aprender o oralismo. Partindo dessa ideia, várias medidas foram tomadas: os professores surdos foram retirados das escolas, os surdos foram proibidos de se comunicarem na sua língua materna (língua de sinais) e iniciou-se um trabalho pela oralização das pessoas surdas. Nesse contexto, a medicina contribuiu de forma significativa para que essas decisões fossem tomadas.

Em vez de procurar mecanismos que possibilitassem uma educação plena para os surdos, a escola fez ao contrário. Ao adotar o oralismo, ela deu início a uma educação que se mostrou repleta de falhas, conflitos, choros, dores e que deixou muitas sequelas. O mais agravante disso tudo, é que ainda hoje encontramos escolas que adotam essa tendência pedagógica. Dessa forma, “o oralismo sempre foi e continua sendo uma experiência que apresenta resultados nada atraentes para o desenvolvimento da linguagem e da comunidade dos surdos." (QUADROS, 1997, p. 22). 
A proposta bilíngue-bicultural surgiu como uma resposta a todos esses males causados pelo oralismo. Aliada a Antropologia e a Linguística, o bilinguismo iniciou a trajetória da reconstrução educacional dos sujeitos surdos. Nessa perspectiva, a língua materna das pessoas surdas passa a ser considerada como a primeira língua e o português (Brasil), como a segunda.

Quanto às identidades dos sujeitos surdos, tema central desse estudo, observou-se que se faz necessário lançar olhares que compreendam todo esse complexo processo, ou seja, se apropriar desses conhecimentos (identidades surdas híbridas, identidade surda de transição, identidade surda incompleta e identidade surda flutuante), objetivando-se uma maior apreensão dos estudos surdos. Somente assim, poderemos travar lutas e retirar da situação de massacre, tal educação.

Criar condições dignas para a educação dos surdos exige, acima de tudo, que eles tenham conhecimento da sua história, da sua trajetória e dessa relação de poder, na qual estão envolvidos. A comunidade surda precisa se organizar, para que seus direitos sejam garantidos.

Ao tomarem conhecimento de sua história, os sujeitos surdos criam suas identidades e, consequentemente, assumem uma postura de defesa, de luta e de busca. Dessa forma, devemos adotar uma postura de luta, para que eles venham ocupar funções e cargos, em todas as áreas do conhecimento: na política, na educação (escolas e universidades), na economia, na justiça, nas manifestações culturais, ou seja, precisamos do surdo sinalizando, decidindo e buscando melhores condições de vida para sua comunidade.

Assim, acreditamos que esses são os anseios daqueles (sujeitos surdos, pais, pesquisadores, parentes e amigos dos surdos) que estão engajados nesse processo de reconstrução da educação dos sujeitos surdos. Portanto, tanto a família quanto a escola, devem conscientizá-los politicamente, para que continuem lutando contra o poder que os subestimam.

\section{REFERÊNCIAS}

DICIONÁRIO universal da língua portuguesa. [2007]. Disponível em: $<$ http:// www.priberam.pt/dlpo/definir_resultados.aspx >. Acesso em 24. out. 2007.

ESCOSTEGUY, Ana Carolina. Os estudos culturais. [2001?]. Disponível em: < http:// www.pucrs.br/famecos/pos/cartografias/estudos_culturais_08_06.php $>$. Acesso em: 04 out. 2007. 
LIMA, Priscila Augusta; VIEIRA, Therezinha. Surdos: a(s) linguagem(ns) como sistemas de representação e organização mental. São Paulo: Avercamp, 2006.

MACEDO, Neusa Dias de. Iniciação à pesquisa bibliográfica. São Paulo: Loyola, 1994.

PERLIN, Gládis Teresinha Tachetto. Identidades surdas. In: (Org.) SKILIAR, Carlos. A surdez: um olhar sobre as diferenças. Porto Alegre: Mediação, 1998.

PINTO, Patrícia Luiza Ferreira. Identidade cultural surda na diversidade brasileira. [2007]. Disponível em: < http://ines.org.br/paginas/revista/debate3.htm > . Acesso em 04.out. 2007.

PRESTES, Maria Luci de Mesquita. A pesquisa e a construção do conhecimento: do planejamento aos textos, da escola à academia. 2. ed. São Paulo: Rêspel, 2003.

QUADROS, Ronice Muller de. Educação de surdos: a aquisição da linguagem. Porto Alegre: Artes Médicas, 1997.

SÁ. Nídia Regina Lima de. Cultura, poder e educação de surdos. Manaus: Editora da Universidade Federal do Amazonas, 2002.

SKILIAR, Carlos. Os estudos em Educação: problematizando a normalidade. In: (Org.) A surdez: um olhar sobre as diferenças. Porto Alegre: Mediação, 1998.

SOARES, Fabiana M. R; LACERDA, Cristina B. F. de. O aluno surdo em escola regular: um estudo de caso sobre a construção da identidade. In: GÓES, Maria Cecília Rafael de; LAPLANE, Adriana Lia Friszman de. (Org.). Políticas e práticas de educação inclusiva. Campinas: Autores Associados, 2004. 



\section{A INCLUSÃO DE ALUNOS COM DEFICIÊNCIA NO ENSINO SUPERIOR: uma análise de seu acesso e permanência}

Telma Brito Rocha

Theresinha Guimarães Miranda

\section{INTRODUÇÃO}

A inclusão social como fator fundamental para equidade e desenvolvimento da sociedade brasileira, hoje, requer que os educadores estejam, permanentemente, informados sobre os processos educacionais e necessidades especiais das pessoas com deficiência e das possibilidades das Tecnologias de informação e Comunicação (TIC). Nessa perspectiva, a criação e aperfeiçoamento de tecnologias assistivas proporcionam à pessoa com deficiência maior independência, qualidade de vida e inclusão social, pois proporcionam a ampliação de sua comunicação, mobilidade, controle de seu ambiente, facilitando o desenvolvimento de habilidades e de condições para seu aprendizado, trabalho e integração com a família, amigos e sociedade.

As TIC têm provocado profundas mudanças na sociedade. Essas mudanças já podem ser visíveis nos diferentes setores produtivos. É fato que o ambiente computacional tende, cada vez mais, a tornar-se uma fonte de informação preponderante e um fator determinante da educação na sociedade atual. No entanto, o setor educacional por sua vez ainda caminha a passos lentos. Enquanto estamos vendo, as linguagens digitais se tornando importantes instrumentos de nossa cultura e, oportunizando inclusão e interação no mundo, a escola e todo sistema de educação, de modo geral, carecem de investimento e 
desenvolvimento de novas práticas a partir das tecnologias, para que se possa experimentar práticas pedagógicas mais democráticas e plurais.

A sociedade, no seu dia-a-dia, precisa se adaptar às necessidades das pessoas com deficiência, dividindo espaços com igualdade e, principalmente, com respeito e aceitação às diferenças. As formas limitadas como as escolas e instituições ainda atuam, têm levado parcela considerável dos alunos à exclusão, principalmente das minorias - sejam elas sociais, sexuais, de grupos étnicos ou de pessoas com deficiência. A base da inclusão consiste no conceito de que toda pessoa tem o direito à educação e que esta deve levar em conta seus interesses, habilidades e necessidades de aprendizagem.

De acordo com estudos de Fortes (2005) é através de instituições de ensino regular que as atitudes discriminatórias se devem combater, propiciando condições para o desenvolvimento de comunidades integradas, que é a base da construção da sociedade inclusiva e consequentemente obtenção de uma real educação para todos.

Embora, a implementação dessa sociedade inclusiva esteja apenas começando, a consecução do processo de inclusão de todos os alunos na escola básica ou na universidade não se efetua apenas por decretos ou mesmo leis, pois requer uma mudança profunda na forma de encarar a questão e de propor intervenções e medidas práticas com a finalidade de transpor as barreiras que impedem ou restringem o acesso e permanência de pessoas com deficiência.

O presente trabalho apresenta o diagnóstico das condições de acesso e permanência do total de 15 alunos que possuem deficiência numa universidade federal e discute ainda as tecnologias computacionais para apoio às pessoas com deficiência, afim de que elas possam desenvolver suas atividades didático-pedagógicas na instituição, proporcionando à pessoa com deficiência maior autonomia, qualidade de vida e inclusão social.

A proposta metodológica para desenvolvimento desta pesquisa foi realizada através da abordagem qualitativa, através do estudo de caso. Segundo Ludke e André (1995, p. 44) "essa abordagem de pesquisa tem preocupação maior com o processo do que com o produto [....."

Inicialmente foi realizada pesquisa bibliográfica, e documental, a respeito da legislação sobre inclusão e necessidades educativas especiais. Logo após foi realizada a identificação dos alunos com deficiência, através de cadastro da universidade, em seguida foram entrevistados 15 alunos com deficiência matricu- 
lados, e 15 coordenadores de cursos, com os quais foram aplicados questionários semiestruturados.

As categorias de análise foram: caracterização da pessoa com deficiência, caracterização da escolaridade anterior do estudante, condições de ensino e aprendizagem na educação superior e de acesso às TIC, em especial às Tecnologias Assistivas.

A Tecnologia Assistiva (TA) é um termo ainda novo, é utilizado para identificar todo o arsenal de recursos e serviços que contribuem para proporcionar ou ampliar habilidades funcionais de pessoas com deficiência e consequentemente promover vida independente e inclusão. Ela vem dar suporte para efetivar o novo paradigma da inclusão na escola e na sociedade para todos, que tem abalado os preconceitos que as práticas e os discursos anteriores forjaram sobre e pelos deficientes.

\section{A LEGISLAÇÃO SOBRE O TEMA}

As últimas décadas foram marcadas por movimentos sociais importantes, organizados por pessoas com deficiência e por militantes dos direitos humanos, que conquistaram o reconhecimento do direito das pessoas com deficiência à plena participação social. Essa conquista tomou forma nos instrumentos internacionais que passaram a orientar a reformulação dos marcos legais de todos os países, inclusive do Brasil. Ao concordar com a Declaração Mundial de Educação para Todos, firmada em Jomtien, na Tailândia, em 1990, e ao mostrar consonância com os postulados produzidos em Salamanca, na Espanha, em 1994 na Conferência Mundial sobre Necessidades Educacionais Especiais: acesso e qualidade, o Brasil fez opção pela construção de um sistema educacional inclusivo. Esses documentos ressaltam que os sistemas educativos devem ser projetados e os programas aplicados de modo que tenham em vista toda gama das diferentes características e necessidades dos alunos.

Dentre os principais instrumentos nacionais que orientam a educação para uma aproximação sucessiva dos pressupostos e da prática pedagógica da educação inclusiva, destacam-se:

- Constituição federal, Título VIII, artigos 208 e 227;

- Lei n. 7.853/89 - Dispõe sobre o apoio às pessoas com deficiência, sua integração social, assegurando o pleno exercício de seus direitos individuais e sociais; 
- Lei n. 10.098/00 - Estabelece normas gerais e critérios básicos para promoção da acessibilidade das pessoas portadoras de deficiência ou com mobilidade reduzida e dá outras providências;

- Lei n. 10.172/01 - Aprova o Plano Nacional de Educação e estabelece objetivos e metas para a educação de pessoas com necessidades educacionais especiais;

- Decreto n. 5.296/04 - Regulamenta as Leis n. 10.048/00, que dá prioridade de atendimento às pessoas com deficiência, e 10.098/00, que estabelece normas gerais e critérios básicos para a promoção da acessibilidade das pessoas portadoras de deficiência ou com mobilidade reduzida, e dá outras providências.

- Lei n. 9.394/96 - Estabelece as Diretrizes e Bases da Educação Nacional;

- Decreto n. 3.289/99 - Regulamenta a Lei n. 7.853/89, que dispõe sobre a Política Nacional para a Integração da Pessoa Portadora de Deficiência, consolida as normas de proteção e dá outras providências;

- Portaria MEC n. 1.679/99 - Dispõe sobre os requisitos de acessibilidade a pessoas portadoras de deficiência para instruir processos de autorização e de reconhecimento de cursos e de credenciamento de instituições.

Apesar de existirem dispositivos legais desde a constituição de 1988, onde se estabelece normatização, de modo que se assegure a equidade de oportunidades e a valorização da diversidade ético-político de todos, nas diferentes esferas de poder, é somente, a partir de 1996, com a lei n. 9394/96, que as instituições de educação superior mais especificamente começam a discutir a questão, já que a legislação ora citada, estabelece responsabilidades bem definidas para a operacionalização de ações dirigidas a inclusão do aluno com deficiência em instituições de ensino.

No entanto, vai ser a Portaria n. 3.284/03 MEC/GM que revogou a Portaria MEC n. 1.679/99, que irá dispor sobre os requisitos de acessibilidade a pessoas com deficiências para instruir processos de autorização e de reconhecimento de cursos e de credenciamento de instituições de ensino superior no País. Por meio desta, o cumprimento destas normas, se encontra atrelada à condição de avaliação da instituição.

A partir desta determinação legal, diretamente relacionada à sua autorização de funcionamento, é que muitas universidades começaram a criar ações que garantam acessibilidade em sua estrutura arquitetônica, embora, segundo dados da presente pesquisa, em uma instituição federal de ensino, revelem que 
o atendimento apenas à infraestrutura espacial, não conseguem minimizar a exclusão destes alunos no ensino superior. Aspectos como as condições didáticopedagógica de trabalho de professores, comprometido pela falta de tecnologias de ajuda para operacionalização de um processo de aprendizagem e inclusão deste aluno de modo pleno, encontram-se entre os principais obstáculos verificados no referido estudo.

\section{A UNIVERSIDADE E A INCLUSÃO DE ALUNOS COM DEFICIÊNCIA NO BRASIL}

$\mathrm{O}$ ingresso do aluno com necessidades educacionais especiais na universidade tem aumentado nos últimos anos, como apontam os dados estatísticos divulgados pelo Instituto Nacional de Estudos e Pesquisas Educacionais Anísio Teixeira (INEP, 2005). Segundo seu último censo, realizado em 2005, as matrículas de alunos com deficiência passaram de 2.155 para 6.022 em cinco anos. Se considerados os alunos superdotados, os matriculados subiram de 2.173 para 6.328 e o aumento percentual foi de $191 \%$.

Isto certamente representa um avanço, mas ainda há muito trabalho a ser feito para que se concretize a inclusão da pessoa com deficiência, considerando que existe um contraste muito grande entre as diversas regiões do País. De acordo com o Inep (2007), 49\% das 6.328 matrículas de alunos com necessidades especiais foram realizadas em Instituições de Ensino Superior (IES) localizadas na Região Sudeste. A seguir vêm o Sul, com $24 \%$ desse total, e o CentroOeste, com 14\%. O Nordeste e o Norte possuem os menores índices de matriculados, concentrando, respectivamente, $9 \%$ e $4 \%$ desse universo de estudantes.

Apesar desses dados mostrarem um salto no número de matrículas, o desafio de uma educação inclusiva no ensino superior precisa ainda alcançar dados qualitativos. Segundo Miranda (2006, p. 7) "o Brasil está em um momento, no qual a democratização do acesso e permanência na universidade de grupos socialmente desfavorecidos está obtendo maior espaço." No entanto, é preciso que a legislação sobre acessibilidade da pessoa com deficiência no ambiente universitário seja mais respeitada, e o atendimento das especificidades de cada tipo de deficiência sejam implementadas tanto por instituições públicas como por instituições privadas, aqui o MEC deve estar acompanhando não apenas a autorização, mas o funcionamento das instituições. Pois, 
[...] enquanto os alunos com deficiência física têm como critério para sua acessibilidade a existência de espaços físicos adaptados (rampas, corrimões, trincos de porta, banheiros, bebedouros, telefones públicos, etc.), em relação à deficiência visual, a acessibilidade depende de materiais como computadores com softwares adequados, impressoras Braille, etc. No concernente a surdez, o aluno deve ter direito a um intérprete em Língua Brasileira de sinais - LIBRAS - por exemplo. (MIRANDA, 2006, p. 6).

Neste sentido o papel social da universidade é fundamental, ela não poderá ser indiferente à diferença, é necessário que se busque um processo educacional mais justo e democrático. É preciso que o estado assuma uma dívida histórica com a educação da pessoa com deficiência. Contudo, aspectos legislativos, como as normas apenas, não vão dar conta da demanda para o setor, é preciso políticas públicas dirigidas com investimentos na qualificação de professores, e recursos tecnológicos, além da assistência estudantil nas universidades públicas em especial, para que se possa garantir a permanência desses estudantes.

Para Marilena Chauí (2003, p. 6),

[...] se quisermos tomar a universidade pública por uma nova perspectiva, precisamos começar exigindo, antes de tudo, que o Estado não tome a educação pelo prisma do gasto público e sim como investimento social e político, o que só é possível se a educação for considerada um direito e não um privilégio, nem um serviço.

No entanto, vemos ainda no espaço da universidade pública e em toda sociedade brasileira, práticas segregadoras, onde se exige um padrão de "normalidade", em nome de uma igualdade, que põem no mesmo nível valores intelectuais e físicos. Logo, as pessoas com características diferentes são discriminadas e estigmatizadas. Ao se definir na nossa sociedade normas e padrões para todos os homens, a exemplo, as formas de acesso à instituição de nível superior, o exame de vestibular, percebe-se nitidamente a padronização do desempenho de candidatos que possuem habilidades e competências diferenciadas. Nesse sentido, é preciso que a universidade trabalhe com igualdade de oportunidades reformulando toda sua forma de ingresso. Só assim ela estaria contribuindo com a superação do discurso sobre a desvantagem e descrédito à pessoa com deficiência. 
Santos (2001) acentua, ainda, a necessidade de se impedir que o foco nas diferenças contribua para isolar grupos, para criar guetos e, consequentemente, para aumentar, na sociedade, a fragmentação que se quer eliminar. É preciso nos prevenir, sustenta, contra um novo apartheid cultural que, visando a criar igualdade, reafirme a separação. A história mostra-nos que igual desenvolvimento e separação jamais conseguiram coexistir. Com separação não há igualdades, há apartheids. "A igualdade só existe quando há possibilidade de se compararem às coisas." (SANTOS, 2001, p. 22).

\section{O CASO DA UNIVERSIDADE FEDERAL DA BAHIA}

O objetivo central deste trabalho de pesquisa realizado entre agosto de 2006 a julho de 2007, foi elaborar um diagnóstico sobre a realidade institucional da Universidade Federal da Bahia (UFBA) em relação às condições de acesso e permanência das pessoas com deficiência no ambiente universitário, visando identificar as necessidades relacionadas à infra-estrutura física e informacional, esta última, relacionada à acessibilidade à tecnologias assistivas.

Observou-se que, a permanência do aluno com deficiência na instituição tem sido exclusivamente promovida através da sensibilização de professores, coordenadores de curso e da família. Isto, segundo eles, é por conta da carência das condições materiais e, principalmente do despreparo dos professores para a interação com as suas necessidades específicas. Alguns deles contaram com o apoio dos coordenadores de colegiado e chefes de departamento que vêm oportunizando as condições necessárias para o desempenho das atividades, a exemplo, de mudança de sala de aula para locais onde o acesso não seja por meio de escadas para os alunos com deficiência física. Para isto, às vezes se faz necessária à negociação entre professores do departamento para que cedam espaços já ocupados por outros professores, ou disponibilidade de apontamento de aulas de professores para o aluno fotocopiar, ou copiar arquivo digitalizado, bem como disponibilidade de computadores de projetos de pesquisas para que o aluno tenha acesso à internet ou edite seus textos.

Resultados da pesquisa ainda indicaram a minimização de barreiras arquitetônicas, em alguns prédios da IES em estudo, como a construção de algumas rampas de acesso, elevadores, e banheiros adaptados. No entanto, isto apenas não consegue promover a acessibilidade física plena. Faltam pistas táteis, corrimão em corredores e salas de aulas, e sinalização visível das vagas para os deficientes nos estacionamentos das unidades. Além de serviço de 
transporte, para aqueles que não possuem carro próprio, dentro do campus, possibilitando ao deficiente físico/cadeirante, dirigir-se com maior facilidade entre as diferentes unidades onde eles possuem aulas. Para o aluno que não possui carro da família a locomoção aos diferentes espaços onde possuem aulas é ainda muito mais difícil. Como afirma o depoimento de um aluno cadeirante abaixo:

Para eu chegar na universidade saio de casa até três horas antes para poder esperar o ônibus que possui acessibilidade, meu pai é que me leva até a faculdade, tenho que pegar dois ônibus até lá, desço num terminal e pego um ônibus para chegar no centro da cidade, lá meu pai fica aguardando entre uma aula e outra para me levar até o outro campus onde tenho outras matérias é muito difícil, quando chego no campus, ainda tenho que andar até a unidade pelas vias que não são muito bem sinalizadas, nem planas, quando chove então, é mais difícil ainda, porque acumula muita água e lama entre ruas e passeios. (Aluno de ciências contábeis com deficiência física).

Depoimento da aluna deficiente auditiva, que cursa administração de empresas, mostra a falta de preparação de professores para atender suas necessidades, pois são pouco utilizados, pelos docentes, recursos tecnológicos como projeção de multimídia. Isso dificulta o acompanhamento das aulas, pois a prática unívoca de transmissão oral de aula pelo professor, sem a consulta de textos ou livros ou outras fontes de pesquisa em rede internet, é um fator que limita, a seu ver, o acompanhamento da aula pelo aluno surdo. A aluna ainda reivindica material de apoio pedagógico, e sensibilização de alguns professores para que suas falas sejam mais dirigidas a ela, para assim poder realizar melhor a leitura labial.

Durante as aulas, eu faço leitura labial, mas nem sempre é possível fazer essa leitura, devido à movimentação do professor, que não se mantém de frente para mim, eu peço para os professores, mas eles esquecem, aí fica difícil acompanhar tudo que o professor fala. Além disso, tem a falta de material onde posso consultar o assunto da aula, alguns professores disponibilizam suas transparências, apontamentos, outros não por que não usam estes recursos. (Aluna de administração deficiente auditiva). 
Como podemos verificar, além de demandas materiais, outras questões ligadas às práticas pedagógicas dos professores se fazem necessárias. A formação de professores no magistério superior para áreas que não são pedagógicas, geralmente, não conta com disciplinas que preparem para o ensino em seus currículos. Por isso, os professores desconhecem as questões relacionadas às necessidades educativas especiais.

Quanto ao acesso às TIC, dos 15 alunos, 14 possuem computadores em suas residências com acesso à internet banda larga, realizam a edição de todos os seus trabalhos acadêmicos em casa, e acessam e-mail diariamente. Por outro lado, uma das alunas relatou que, por conta da falta de acessibilidade do laboratório de sua unidade de ensino, ela tem que acessar a internet em lan house do bairro onde mora, ou se deslocar até o setor Braile da Biblioteca Central do Estado da Bahia para edição dos seus trabalhos acadêmicos.

Entrevistas com o total de 15 coordenadores de cursos onde existem estudantes com deficiência, revelaram o desconhecimento, no tocante às questões conceituais sobre Educação Especial. Os mesmos apontaram a importância de estar discutindo legislação, diagnóstico e aprendizagem sobre a pessoa com deficiência entre docentes e funcionários técnico-administrativo. Assim, poderiam melhor incluir os deficientes na rotina acadêmica. Sugestões de uma entrevistada apontam alguns caminhos:

Intercâmbio com instituições preparadas para treinamento dos professores a fim de lidar com os deficientes para inserí-los na rotina acadêmica. Quando da inserção dos alunos na Universidade crie-se um meio de identificação do tipo de deficiência que o ingresso possui, podendo contar com a colaboração do Serviço Médico Universitário Rubens Brasil (SMURB) da própria instituição, assim como, atendimento pedagógico especializado ao longo do curso deste ingresso. (Coordenadora do curso de enfermagem).

Sobre adaptações curriculares para atender ao aluno deficiente, dos 15 coordenadores de cursos entrevistados, apenas cinco declararam que existe ampliação do tempo para a realização das provas, monitoria para colaborar com aprendizagem desses alunos, assim como ampliação do tempo de curso para aqueles que necessitarem.

Para González (2002) qualquer aluno sendo formado para ser professor deveria receber uma adequada preparação básica, que lhe proporcionasse algu- 
mas estratégias para desenvolver seu trabalho com alunos que apresentam necessidades específicas, de modo a poder oferecer-lhes respostas adequadas em habilidades e atitudes relacionadas às situações cotidianas. $\mathrm{O}$ autor entende que "[...] os objetivos da formação inicial deveria incluir dimensões relativas aos conhecimentos, destrezas, processo de atenção à diversidade dos alunos." (GONZÁLEZ, 2002, p. 245).

Se esses alunos tivessem acesso aos recursos tecnológicos que estão disponíveis na sociedade teriam, com certeza, uma melhor qualidade de seu processo de aprendizagem e consequente inclusão no meio acadêmico em que circulam. Nessa perspectiva, algumas tecnologias assistivas favorecem o atendimento educacional dos acadêmicos com deficiência na Universidade.

\section{CONCLUSÃO}

Resultados desta pesquisa apresentam indicadores de necessidades para efetivar o atendimento educativo adequado para a permanência dos estudantes com deficiência na UFBA. É preciso que a instituição promova políticas mais diretivas para a inclusão da pessoa com deficiência no ambiente acadêmico.

O pouco número de estudantes que têm acesso a IES em estudo, ainda é insignificante em face ao número de estudantes que tem a instituição, aproximadamente 20.000 alunos, de acordo com informação da Pró-Reitoria de Planejamento e Administração (UNIVERSIDADE FEDERAL DA BAHIA, 2008). Verifica-se, assim, que além de uma política de permanência, a universidade deve promover uma discussão na sociedade sobre a política de acesso ao ensino superior, oportunizando alternativas, tais como curso de pré-vestibular, entre outras ações, que minimizem a falta de oportunidade desses estudantes excluídos de contextos educativos regulares.

Neste sentido, constatamos que a instituição deve promover ainda a sensibilização de equipes diretivas das unidades acadêmicas, dos professores e dos funcionários técnico-administrativos, para que possa haver maior interação entre o aluno deficiente e a comunidade acadêmica. Além disso, a criação de um laboratório de apoio pedagógico, onde o aluno contasse com a ajuda de tecnologias e profissionais, tais como: pedagogo, psicólogos, psicopedagogos, fonoaudiólogos, profissionais da computação entre outros, disponíveis para criar soluções tecnológicas e pedagógicas para o atendimento aos estudantes. 


\section{REFERÊNCIAS}

BRASIL. Ministério da Educação. Portaria n. 3.284, de 7 de novembro de 2003. Dispõe sobre requisitos de acessibilidade de pessoas portadoras de deficiências, para instruir os processos de autorização e de reconhecimento de cursos, e de credenciamento de instituições. Diário Oficial da União. Poder Executivo. Brasília, DF, 03 dez. 1999.

. Diretrizes nacionais para a educação especial na educação básica. Brasília, 2001.

. Secretaria de Educação Especial. Direito à Educação: subsídios para a gestão dos sistemas educacionais: orientações gerais e marcos legais. Brasília, 2004.

. Coordenadoria Nacional para Integração da Pessoa Portadora de Deficiência.

Acessibilidade. Brasília: Secretaria Especial dos Direitos Humanos, 2005.

CHAUI, Marilena. A universidade pública sob nova perspectiva. Rev. Bras. Educ., Rio de Janeiro, n. 24, set./dez. 2003. Disponível em: < http://www.scielo.br/ scielo.php?script $=$ sci_arttext\&pid $=\mathrm{S} 1413-24782003000300002 \& \operatorname{lng}=\mathrm{en} \& \mathrm{nrm}=\mathrm{iso}>$. Acesso em: 06 maio 2007.

FORTES, Vanessa Gosson Gadelha de Freitas. A inclusão da pessoa com deficiência visual na UFRN: a percepção dos acadêmicos. Dissertação (Mestrado em Educação) - Universidade Federal do Rio Grande do Norte, 2005.

GONZÁLEZ, José Antônio Torres. Educação e diversidade: bases didáticas e organizativas. Porto Alegre: ARTMED Editora, 2002.

INEP. Censo da Educação Superior: sinopse estatística 2005. 2007. Disponível em: $<$ http://www.publicacoes.inep.gov.br/detalhes.asp?pub=4281\# > . Acesso em: 22 out. 2007.

LÜDKE, Menga; ANDRÉ, Marli E. D. A. Pesquisa em Educação: abordagens qualitativas. São Paulo: EPU, 1995.

MIRANDA. Theresinha Guimarães. A inclusão de pessoas com deficiência na universidade. SEMINÁRIO DE PESQUISA EM EDUCAÇÃO ESPECIAL, 2., 2006. Vitória, ES. Anais... Vitória, ES: UFES, 2006.

SANTOS, Boaventura de Sousa. Dilemas do nosso tempo: globalização, multiculturalismo e conhecimento. Educação \& Realidade, Porto Alegre, v. 26, n. 1, 2001.

UNIVERSIDADE FEDERAL DA BAHIA. Pró-Reitoria de Planejamento e Administração. UFBA em números 2008. 2008. Disponível em: < http://www.proplad.ufba.br/ numeros_ufba_2008-f.html>. Acesso em: 13 nov. 2009. 



\section{REFLEXÕES SOBRE A INCLUSÃO LINGUÍSTICA NO CONTEXTO ESCOLAR}

Iara Rosa Farias

Antônio Fernando Santos

Érica Bastos da Silva

\section{INTRODUÇÃO}

A palavra inclusão (1999) vem do latim, do verbo includere e significa "colocar algo ou alguém dentro de outro espaço", "entrar num lugar até então fechado". É a junção do prefixo in (dentro) com o verbo cludo (cludere), que significa "encerrar, fechar, clausurar". O termo, cada vez mais, é aplicado não apenas para questões das necessidades especiais, como também para construir discursos de acessibilidade a quaisquer indivíduos que estão excluídos de determinados espaços e situações, fala-se, por exemplo, em inclusão digital, econômica, entre outras. Assim, ao utilizarmos a palavra podemos nos referir tanto especificamente às pessoas com necessidades especiais quanto a atitudes de inclusão que se referem a outras situações observadas em nossa sociedade.

Para este I Congresso Baiano de Educação Inclusiva: a deficiência como produção social vamos abordar um tipo de inclusão que se faz urgente em nossa sociedade, pois atinge tanto pessoas com necessidades especiais quanto pessoas ditas normais. Vamos tratar da "inclusão linguística". Para isso faremos o seguinte percurso: iniciaremos com um panorama histórico, a título de horizonte discursivo, sobre a atitude inclusiva. Em seguida, trataremos da instituição que, nas últimas quatro décadas, por sua configuração como espaço sociat, tem bus- 
cado promover a inclusão: a escola. Por fim, abordaremos a questão da "exclusão/inclusão linguística" e faremos proposições.

\section{HORIZONTES $^{1}$}

O discurso sobre a inclusão de pessoas com necessidades especiais tem mudado no decorrer dos tempos em função de determinadas transformações sociais, culturais e econômicas.

Durante muitos anos, determinadas deficiências foram consideradas praticamente como sinônimo de castigo. No período da Inquisição e, posteriormente, na Reforma Protestante, as pessoas com necessidades especiais eram tratadas como uma personificação do mal. Com decorrer das décadas e com os avanços da Medicina, novos conceitos foram sendo construídos e reconstruídos em relação a tais pessoas.

Estudos e pesquisas, devido ao desenvolvimento científico, mostraram as razões e a origem das diversas deficiências humanas e que estas não estavam relacionadas e não eram o mal. Começaram, então, a surgir as primeiras práticas sociais voltadas para um maior cuidado com essas pessoas. Entretanto, o que acontecia tanto na Europa, quanto no Brasil, no período Imperial era apenas a institucionalização da deficiência, ou seja, as pessoas com necessidades especiais ficavam em suas residências enclausuradas e estavam, portanto, excluídas da participação social mais ampla.

Esse modelo de institucionalização permaneceu até meados da década de 50 do século XX. Nesse período houve algumas mudanças no que se refere aos movimentos sociais. Um dos principais acontecimentos, em 1948, a elaboração da Declaração Universal dos Direitos Humanos pela Assembléia Geral das Nações Unidas $^{2}$, na qual, em seu artigo $1^{\circ}$, se reconheceu que "todos os seres humanos nascem livres e iguais, em dignidade e direitos." De um modo geral, essa declaração assegurou às pessoas, pelo menos no papel, os direitos à liberdade, à educação e ao convívio social.

Foi a partir da década de 60, do século passado, que se iniciou uma intensa movimentação mundial em defesa dos direitos das minorias (ou de maiorias), pautada principalmente nos direitos humanos (ORGANIZAÇÃO DAS NA-

\footnotetext{
${ }^{1}$ Neste tópico tomaremos como fonte principal o documento do Ministério da Educação sobre educação inclusiva (BRASIL, 2004).

${ }^{2}$ A declaração foi aderida pelos países membros das Organizações das Nações Unidas (ONU).
} 
ÇÕES UNIDAS, 1948). Houve, por grande parte dos países, uma defesa da chamada desinstitucionalização, buscando-se assim a inclusão em sentido geral e mais amplo, principalmente no que diz respeito ao aspecto da participação/ produção social. Os avanços da psicologia da instrução permitiram uma visão de tais pessoas como seres humanos concretos, produtivos (física e intelectualmente), com processos especiais e que em razão disso não podiam simplesmente ser agrupados e excluídos do convívio social.

Na década de 80, do século passado, em diante, ocorrem transformações mais profundas nas sociedades, principalmente com a utilização das novas tecnologias. Estas possibilitam, por exemplo, a comunicação em tempo real com qualquer pessoa, em qualquer parte do mundo. Em razão disso, não é apenas a comunicação que é facilitada, mas o acesso à novas informações e a um maior conhecimento de mundo.

É nesse contexto que se evidencia ainda mais a discussão sobre a diversidade. Já na década de 90 do mesmo século, por exemplo, prolifera-se um discurso segundo o qual a diversidade enriquece e humaniza a sociedade. Começou-se a delinear a ideia de construção de espaços sociais que propiciassem o atendimento das necessidades de todos os cidadãos, construindo-se assim uma única educação, que fosse realmente inclusiva. Esta é definida por Mrech (2007) como "o processo de inclusão dos portadores de necessidades especiais ou de distúrbios de aprendizagem na rede comum de ensino."

Nesse período ocorrem alguns eventos mundiais. A Conferência Mundial de Educação para Todos acontece em 1990, em Jomtiem, na Tailândia, na qual o Brasil assumiu o compromisso de erradicar o analfabetismo e universalizar o ensino fundamental no país. Em 1994, se constitui, na Espanha, a Declaração de Salamanca que tem por objetivo discutir a questão das pessoas com necessidades especiais. Com o intuito de cumprir esses acordos, o Brasil tem criado instrumentos norteadores e documentos legais com o objetivo de possibilitar a criação de sistemas educacionais que sejam inclusivos.

A partir da Constituição Federal, promulgada em 1988, o governo brasileiro assumiu, formalmente, o compromisso do oferecimento da educação para todos (capítulo III, artigo 208). A promulgação de marcos legais específicos para a inclusão, como as Diretrizes Nacionais para a Educação Especial na Educação Básica e a criação de espaços adaptados estruturalmente para atender as demandas da inclusão, propiciam, assim, aos educandos com necessidades especiais, o direito de frequentar a escola, que é um dos principais espaços sociais. 
Nos dias atuais, a inclusão vem sendo amplamente discutida e ressignificada. Os meios de comunicação de massa têm trazido, através de novelas, de comercias, por exemplo, situações para promover a reflexão de como as pessoas com necessidades especiais podem exercer seus direitos de cidadãs. Tanto no contexto escolar, quanto fora dele, os discursos sobre a inclusão estão acontecendo cotidianamente, potencializando assim um repensar sobre a forma de tratar o tema da diversidade e das diferenças.

Mesmo neste contexto de discussão sobre a inclusão há, no entanto, questões que não estão resolvidas, embora exista um cenário de transformação. Acreditamos ser necessário, discutir, ainda, determinados temas, que precisam ser aprofundados, para haver uma transformação concreta, real, efetiva, pois há formas mais sutis de exclusão que coexistem com o discurso da inclusão. Podemos citar a exclusão étnica, econômica, política e muitas outras. Em razão dos limites de um artigo e dos objetos de pesquisa dos autores que escrevem este trabalho, trataremos da exclusão que se constitui pela e na linguagem e da relevância em se promover tal tipo de inclusão.

No próximo tópico trataremos de um espaço em que se promove a exclusão linguística: a escola; embora muito já se tenha feito para reverter este quadro. Começaremos por entender a dinâmica deste local.

\section{PARADOXO ESCOLAR: ESPAÇO DE INCLUSÃO/EXCLUSÃO}

A partir da década de 1960, um olhar radicalmente diferente vai ser lançado sobre a escola. Estudos produzidos por diversos países, principalmente EUA, França e Inglaterra, são divulgados com o intuito de entender o desempenho educacional nada satisfatório de determinados grupos sociais após o processo de massificação do ensino.

Nesse contexto, surgem reflexões e discussões sobre a massificação do ensino e o fracasso escolar. Temos, então, pensadores que se voltam para estes problemas especificamente e são conhecidos como os teóricos da reprodução, com destaque para o francês Pierre Bourdieu, graduado em Filosofia, porém filiado ao Centro Europeu de Sociologia. Ele analisa e explica a educação escolarizada, explicitando, claramente, a escola como lugar de manutenção e de legitimação de privilégios.

Para Bourdieu (1999), os estudantes não são seres ideais que competem na escola em situação de igualdade; são sujeitos socialmente constituídos com uma bagagem social e cultural que têm valor diferenciado, marcando significa- 
tivamente a sua trajetória na instituição escolar. A neutralidade da escola e do conhecimento escolar são fortemente questionados pelo sociólogo, mostrando como os gostos, as posturas, os valores da classe social economicamente favorecida são dissimuladamente apresentados como cultura universal.

A partir deste ponto de vista, o tratamento uniforme dado pela escola só vem reforçar as desigualdades e as injustiças sociais, uma vez que acaba favorecendo um tipo específico de indivíduo cuja cultura familiar já é próxima desse fazer educativo: "[...] todas as normas [...], tendem sempre a favorecer o sucesso (pelo menos no interior da instituição) de um tipo modal de homem [...]" (BOURDIEU, 1999, p. 267). Em termos mais simples, a escola por não considerar as diferenças, ao trabalhar com um modelo de educando, o tipo modal, agrava mais as desigualdades.

No caso específico da educação pública brasileira, a escola tem sido muito mais um espaço de exclusão social do que propriamente de abertura de oportunidades. Os altíssimos índices de evasão e de repetência, por exemplo, estão aí para comprovar; sem falar no contingente cada dia maior de analfabetos funcionais que são produzidos anualmente. Assim, ano após ano, a imprensa vem apontando e alardeando os resultados nada satisfatórios obtidos pelos alunos brasileiros, tanto em exames nacionais como o Exame Nacional do Ensino Médio (ENEM) e o Sistema de Avaliação da Educação Básica (SAEB), quanto em internacionais como o programa internacional de avaliação comparada desenvolvido e coordenado, em âmbito internacional, pela Organização pelo Cooperação e Desenvolvimento Econômico (OCDE), o Programme for International Student Assessment (PISA). Uma gama bastante diversa de fatores corrobora para esse estado calamitoso de nossa educação.

No Brasil, o perfil sociocultural dos indivíduos que chegam até a escola mudou consideravelmente a partir das décadas de 60 e 70 do século XX, com a chamada "democratização da escola pública". A partir de então, o alunado deixou de ser exclusivamente das classes médias urbanas (em função das quais sempre foram organizados os currículos e preparados os materiais didáticos) e passou a ser também de filhos de pais iletrados, principalmente advindos das cidades interioranas. Surgiu aí o fenômeno do fracasso escolar quando uma boa parte dos alunos passou a ser sistematicamente "expulsa" de nossas salas de aula.

A escola passa a exercer uma violência simbólica: impõe-se um tipo de saber como único; pior, ele é legitimado como saber único e irrefutável. Reforça-se a discriminação a determinados grupos sociais que pode, na sua for- 
ma mais radical, se configurar em termos de marginalização. Esse saber único é reforçado e cristalizado em algo comum ao indivíduo, mas que por ser tão natural, muitas vezes, não recebe a atenção devida. Estamos falando da linguagem.

No próximo tópico trataremos do que chamamos de exclusão linguística e o modo como ela se manifesta no espaço escolar.

\section{A DIVERSIDADE LINGUÍSTICA E SEU APAGAMENTO NA ESCOLA}

Antes de falar de forma mais detida sobre o assunto, vamos buscar esclarecer para o leitor o que se entende neste trabalho por linguística. Não estamos aqui abordando a disciplina que se ocupa dos fenômenos da linguagem ou nos termos do dicionário do Instituto Antônio Houaiss (2009):

ciência que tem por objeto: (1) a linguagem humana em seus aspectos fonético, morfológico, sintático, semântico, social e psicológico; (2) as línguas consideradas como estrutura; (3) origem, desenvolvimento e evolução das línguas; (4) as divisões das línguas em grupos, por tipo de estrutura ou em famílias, segundo critérios tipológicos ou genéticos.

Usamos a palavra linguística, neste artigo, como o uso que os falantes fazem de sua língua materna, ou seja, estamos abordando a linguagem oral e escrita dos indivíduos no seio de uma sociedade e de uma cultura. Enfim, entendemos o termo linguística/o como a capacidade dos indivíduos de se expressarem na sua língua, tanto na forma oral quanto na, escrita ou ainda pela Linguagem Brasileira de Sinais (Libras) ou Braille.

Todo indivíduo ao nascer dentro de uma sociedade utiliza-se da linguagem e, portanto, pode desenvolver sua capacidade linguística. As pessoas que se utilizam da Libras ou do sistema Braille exercitam sua capacidade linguística de outro modo menos generalizado. O exercício pode ser diferenciado, porém a função do sistema de que se utilizam é a mesma: comunicar ideias, expressar emoções, convencer o interlocutor, enfim, constituir um diálogo. Noutros termos, a linguagem tem um caráter fundamentalmente social: a comunicação.

Ao se trabalhar diretamente com a linguagem constata-se, de modo muito evidente, a existência de formas diversas no falar; são variações (variantes) que obedecem a diferentes fatores: regional, de gênero, situacional, sociocultural 
etc. No entanto, na escola é trabalhada apenas a variante considerada de prestígio, a chamada Norma Padrão (NP). As outras formas de realizações do falar não recebem atenção por serem entendidas como variantes não prestigiadas pela sociedade em geral.

Noutros termos, a escola, devido à necessidade de atender aos objetivos para os quais foi criada, tem se fixado na variante padrão ou NP, denominação da variante linguística mais socialmente valorizada. A NP é requerida em ocorrências de interação determinadas, em função da situação, do assunto tratado, da relação entre os interlocutores etc.

A exclusão acontece, no que diz respeito à linguagem oral e escrita, porque existe um parâmetro para nortear o exercício linguístico, mas que acaba por ser tomado como baliza de classificação de "certo" e de "errado". Esclarecendo, o que se chama de NP para o exercício da oralidade e da escrita, passou a ser entendido como a única e definitiva forma de um sujeito se expressar por meio da sua língua materna. Quem não fala e não escreve segundo a NP passa a ser discriminado socialmente, sofrendo sanções negativas. Conforme nos alerta $\operatorname{Abud}(1987$, p. 23):

Quando a escola ensina a norma lingüística [...] dos setores favorecidos da sociedade, como a língua correta ou de prestígio, toma a atitude de rejeitar e pretender substituir variedades lingüísticas usadas pelos alunos, pela única variedade que aceita.

Dessa forma, a escola legitima e impõe um modelo linguístico único em detrimento das demais formas de expressão dos seus educandos. Estabelece um modelo cultural exclusivo, sem considerar a diversidade cultural vivenciada, incorporada pelos seus alunos, principalmente daqueles que não dominam ainda a NP, e dessa forma constitui-se "[...] uma pedagogia de assimilação cultural, de adoção de novos padrões lingüísticos ditos cultos na excludência daqueles que marcam a identidade cultural do núcleo familiar" (MOTA, 2002, p. 7). Ou como diria Soares (1989), é dessa forma que na nossa escola, diferença vira sinônimo de deficiência.

Diante do exposto acima, o professor pergunta: o que fazer? Não ensinar a NP a seus alunos e, em razão disso, prejudicar suas aprovações no vestibular ou suas admissões em empregos, por exemplo? Acreditamos que podemos refletir sobre o problema e fazer algumas proposições para superá-lo. Trataremos disso no próximo tópico, onde faremos nossas considerações finais. 


\section{CONSIDERAÇÕES FINAIS OU A ESCOLA COMO ESPAÇO DO EXERCÍCIO DA DIFERENÇA}

Uma sociedade é formada por indivíduos, seres humanos concretos, com suas especificidades, suas diferenças, seus sonhos, suas necessidades materiais ou não, seus projetos de vida. E a escola deve, em certa medida, atender a essas demandas individuais, como deve também criar outras. Noutros termos, a escola deve ser o ponto de encontro, o ponto de equilíbrio, entre diversos projetos, tanto coletivos, quanto individuais. É um espaço de gestação de um novo mundo, como bem destaca Kuenzer [2006] em texto divulgado na Internet:

A escola é o lugar de aprender a interpretar o mundo para poder transformá-lo, a partir do domínio das categorias de método e de conteúdo que inspirem e que se transformem em práticas de emancipação humana em uma sociedade cada vez mais mediada pelo conhecimento.

Refletindo sobre as palavras acima, e buscando fazer delas uma realidade, o que cabe a nós educadores? Inicialmente, é preciso ter claro que as mudanças são realizadas de maneira paulatina, mesmo assim, faz-se absolutamente necessário empreendê-las. No que diz respeito ao trabalho com a linguagem dentro da escola, uma das maneiras mais eficiente de se transformar essa exclusão linguística é o investimento na melhor formação do professor. Não apenas do professor de Língua Portuguesa considerado, muitas vezes, como o único responsável pelo "ensino de português". É preciso investir na formação/educação linguística dos professores, e aqui estamos nos referindo ao estudo de algumas características e particularidades do sistema da língua materna. Um professor que não sabe ou não está atento para as particularidades do sistema do português (o som /S/ pode ser representado por várias letras S, SS, SC, X, Ç, SÇ, por exemplo) ou das suas características (o português possui uma unidade, mas não possui homogeneidade devido as suas variantes), não vai entender e tolerar o educando que não se expressa, ainda, por meio da NP.

A escola tem a função de ensinar seus educandos, por meio dos seus professores, a dominar a NP, porque ela é exigida pela sociedade. O que a escola e os professores não podem e não devem fazer é promover a discriminação de quem não exerce a NP, por não entender ainda que é por meio dela que se organiza determinadas relações sociais e que ela é utilizada como meio de acessibilidade à ampliação da capacidade de comunicação. 
Promover cursos de formação de professores (e não meros cursos de capacitação que muitas vezes não levam à reflexão necessária) na área de linguagem é um modo bem eficiente de se começar a tornar a escola um espaço mais inclusivo, porque ela (a linguagem) está em nós cotidianamente, organizando nossos pensamentos, sentimentos, emoções e opiniões. Noutros termos, a linguagem organiza nossa visão de mundo e nosso estar no mundo, quer sejamos portadores de necessidades especiais, quer sejamos portadores de outras necessidades, como seres humanos inconclusos que todos somos. É por meio dela que nos comunicamos, por isso é relevante estudá-la e compreender seu papel no cotidiano e nas interações sociais.

A linguagem é, sem sombras de dúvidas, a grande ponte que liga o "eu" ao "tu", o "eu" ao "diferente de mim" (ao outro). Um forte e poderoso instrumento para os que acreditam num mundo mais harmônico, melhor para todos, sem distinções. Porém, para que isso ocorra, reiteramos, é necessário entendêla, reconhecer o seu poder nas relações sociais e observá-la em toda sua plenitude. E que isso não fique restrito a alguns profissionais, mas seja parte da bagagem cultural de todos os que trabalham com educação, inclusive dos nossos educandos.

\section{REFERÊNCIAS}

ABUD, Maria José Milharezi. O ensino da leitura e da escrita na fase inicial de escolarização. São Paulo: EPU, 1987.

BOURDIEU, Pierre. A economia das trocas simbólicas. São Paulo: Perspectiva, 1999.

BRASIL. MINISTÉRIO DA EDUCAÇÃO. Secretaria de Educação Especial. Educação inclusiva: a fundamentação filosófica. Organizado por Maria Salete Fábio Aranha. Brasília, DF, 2004. v. 1 Disponível em: < http://portal.mec.gov.br/seesp/arquivos/pdf/ fundamentacaofilosofica.pdf>. Acesso em: 15 out. 2009.

BRASIL. Constituição (1988). Constituição da República Federativa do Brasil. São Paulo: Saraiva, 1988.

INCLUSÃO. In: FERREIRA, Aurélio Buarque de Holanda. Novo Aurélio século XXI: o dicionário da língua portuguesa. Rio de Janeiro: Nova Fronteira, 1999.

KUENZER, Acácia Zeneida. Conhecimento e competências no trabalho e na escola. [2006]. Disponível em: < http://www.senac.br/informativo/BTS/282/boltec282a.htm> Acesso em: 08 jan. 2006.

LINGUÍSTICA. In: INSTITUTO ANTÔNIO HOUAISS. Houaiss Eletrônico. Versão monousuário 3.0. Rio de Janeiro: Objetiva, 2009. 
MOTA, Kátia. A linguagem da vida, a linguagem da escola: inclusão ou exclusão? Uma breve reflexão lingüística para não lingüistas. Educação e Contemporaneidade, Salvador, v. 11, n. 17, p.13-26, jan./jun. 2002.

MRECH, Leny Magalhães. O que é educação inclusiva? [2007]. Disponível em: < http:// www.geocities.com/Athens/Styx/9231/educacaoinclusiva.html> Acesso em: 07 out. 2007.

ORGANIZAÇÃO DAS NAÇÕES UNIDAS. Declaração Universal dos Direitos Humanos. Disponível em: <http://www.dhnet.org.br/direitos/deconu/textos/integra.htm >. Acesso em: 17 out. 2009.

SOARES, Magda. Linguagem e escola: uma perspectiva social. São Paulo: Ática, 1989. 


\section{A PERCEPÇÃO DA TRIBO INDÍGENA PANKARARÉ SOBRE O ÍNDIO COM DEFICIÊNCIA VISUAL}

Patrícia Carla da Hora Correia Daniela Fernanda da Hora Correia

\section{INTRODUÇÃO}

O debate sobre a questão inicia-se colocando que inclusão e exclusão são lados da mesma moeda, pois discutir a viabilidade da inclusão da pessoa com deficiência visual na tribo é, ao mesmo tempo, levantar inquietações sobre a organização e a produção social dessa pessoa na tribo.

O resgate da identidade indígena encontra cada vez mais respaldo nas lutas e reivindicações sobre a posse da terra, desenvolvimento e preservação da cultura. As políticas públicas da inclusão perpassam necessariamente pela exclusão dos grupos desfavorecidos em nosso País. O leque da exclusão é tão grande quanto são os padrões de normalidade que se impõem aos grupos minoritários por sua condição de raça, cor, etnia, ou por suas diferenciações cognitivas e psicológicas ou mentais. Esses padrões muitas vezes impõem a desarticulação dessas minorias retirando os membros do palco das discussões. É assim que acontece com o índio, e é assim que acontece com a pessoa com deficiência visual dentro da Tribo Pankararé.

Nesse contexto, encontramos na tribo um discurso marcado pelo senso comum. Os próprios índios, no início da invasão, desprezavam a criança que nascia com deficiência à própria sorte, o que consequentemente, as levava à morte. Alguns pais eram responsáveis por matar seus filhos, mesmo antes das 
mães olharem para eles (FERNANDEZ, 1959). Nessa época, prevalecia a uniformização exterior das ações dos indivíduos, pois os índios não conseguiam viver com mudanças bruscas e a presença de um índio com deficiência, na tribo, desestabilizava a ordem social e, consequentemente, esse indivíduo não respondia aos seus deveres como cidadão.

O índio com deficiência na tribo é:

Aquele que depende de alguma pessoa para sobreviver. (Cacique)

Essas pessoas vivem com a família que ajuda a sobreviver, busca o alimento para ele sobreviver. (Cacique).

[...] o surdo não tem sobrevivência completa. Ele não pode estar no mato sozinho, pois se houver uma picada de cobra ou corte de machado ou cair no buraco que vai cavar, não tem como ele gritar para alguém ouvir. Então ele, para sobreviver, precisa de alguém junto. (Pajé).

São aquelas pessoas que não têm a responsabilidade de ser uma pessoa que não desenvolveu mais. (Esposa).

Ele, conforme o nascimento, nasceu naquela região, sabe andar na sua localidade. Eles sofrem porque depende de alguém para orientar. Cada dia que a gente tem, tem uma sobrevivência de vida. Aí as pessoas da família passa pra ele como é aquele dia-adia para sobreviver. (Cacique).

A acepção que o homem dá a realidade é medida pelo outro, que delimita, indica e atribui significados ao meio em que está inserido. Na tribo, os índios com deficiência assumem uma postura submissa, reservando ao outro o seu desenvolvimento. A ideia que os índios têm sobre os índios com deficiência é que determina a ação destes na comunidade (OMOTE, 1994).

Assim, diante das respostas acima, pode-se considerar que um ser humano estigmatizado vai desempenhar papéis referentes às suas características, não lhes sendo possível desenvolver outras habilidades. $\mathrm{O}$ sentido de anormalidade justifica, em certos momentos, a exclusão, a marginalização. A sociedade administra os desvios marginalizando os indivíduos cujas características físicas, raciais ou comportamentais não se encaixam no padrão de normalidade. Esses desvios fazem com que as pessoas sejam estigmatizadas e discriminadas, afastadas inconscientemente da vida em comum (OMOTE, 1994). 
O cego tem alguma arte [...] E o restante da situação de cego até pra ele fazer xixi ou cocô lá fora, uma pessoa sadia tem que pegar na vara pro mode ele seguir. (Cacique).

O cego na tribo [...] o cego é aleijado aqui é esperar caixão para se enterrar. Se é cadeira de roda, a FUNAI nunca deu pra ninguém. Não existe esse critério dentro das normas da FUNAI. Se tem funcionário pra pedir cadeira de roda pro índio, ele não se preocupa. Ele quer receber o dinheiro dele. $\mathrm{O}$ índio que se dane. [...] O surdo trabalha um pouco. (Pajé).

Os relatos acima parecem não romper com os limites da intuição. Não só não recorrem às formulações teóricas já sistematizadas, como dão a impressão de desconhecimento. Desconhecem a gênese de cada deficiência, as implicações primárias e secundárias, limitando, na maioria dos casos, o índio com deficiência à sua deficiência, não estimulando o desenvolvimento biopsicossocial dessas pessoas.

É claro que se deve considerar a situação econômica, social e cultural da tribo indígena. Por conta da própria história das pessoas com deficiência no Brasil, desde o início da invasão, pode-se até arriscar a dizer que esse pensamento e essa atitude contra o índio com deficiência são oriundos da morte, da separação desses indivíduos da vida social, hoje amenizando-se, provavelmente, por uma influência não indígena de aceitação, marcada por exclusão, isolamento e limitação do índio com deficiência.

Aí que é pior ainda. Invés de ser cego um, fica dois, três tomando conta desse cego. Preocupa mais. Invés da pessoa trabalhar para criar um filho, vai é cuidar desse cego. É difícil. É aquilo que eu digo: - Deveria ter uma separação esse tipo de gente, né? (Pajé).

Diante do relato acima, é marcante a questão do desconhecimento na tribo. Esse desconhecimento gera um preconceito que constrói e determina o olhar, ouvir e sentir das pessoas na tribo Pankararé. Analisando sob essa óptica, o desenvolvimento das capacidades desses índios com deficiência fica restrito à sua deficiência. Mas uma vez, enfatiza-se apenas a deficiência descritiva que se instala e estabelece nas relações entre os seres humanos. Dentro da sociedade, pela própria relação de poder que existe, fica difícil estudar a deficiência sem a vinculação com a incapacidade. Essa mantém a estrutura do desvio e justifica a própria exclusão. 
Neste sentido cabe o estudo sobre a teoria do defeito enfatizado por Vigotski, pois o autor destaca que o desconhecimento da estrutura da defeito pode conduzir à separação ou segregação dos índios com deficiência visual do seio da sociedade, que ignora suas reais possibilidades. O estudo da estrutura do defeito possibilita um diagnóstico mais preciso da deficiência, conduzindo a processos coerentes e compensatórios, confirmando o postulado central da Defectologia ${ }^{1}$ contemporânea:

Cualquier defecto origina estímulos para la formación de la compensación. Por eso el estudio dinámico del niño que presenta deficiencias no puede limitarse a la determinación del grado y de la gravedad de la insuficiencia, pero incluye indispensablemente el control de los procesos de compensación, de substitución, procesos edificadores e equilibradores en el desenvolvimiento de la conducta [...]. (VIGOTSKI, 1997, p. 5).

O desconhecimento da origem de cada estrutura limita o ser humano à sua deficiência e, consequentemente, impede o seu desenvolvimento biopsicossocial, podendo determinar a visão das pessoas, na Tribo Indígena Pankararé. Neste momento, surge o estigma, o diferente, justificando, em certos casos, a própria exclusão.

Diante de tais constatações, o conhecimento dessas estruturas pode contribuir para a participação do deficiente na sociedade. Pois esse conhecimento permite determinar ações que visem a desenvolver funções psicológicas importantes na vida do próprio deficiente: serviços, planejamento e organização de programas de intervenção e determinação dos seus efeitos. Sem contar que o conhecimento proporciona mudança de atitudes, favorecendo, assim, a construção de uma sociedade mais justa e contribuindo para o processo de humanização.

$\mathrm{Na}$ tribo indígena Pankararé esse conhecimento poderá proporcionar uma melhor inclusão do índio com deficiência visual na tribo, diminuindo o processo de discriminação, oferecendo um maior desenvolvimento de suas potencialidades e promovendo a formação do homem pleno.

Alguns familiares consideram que a deficiência compromete a capacidade para realizar atividades que, em seu meio, são consideradas normais para o

\footnotetext{
${ }^{1}$ Termo utilizado por Vigotsky (1997). Designa a pedagogia especial científica, com base marxistaleninista. Essa obra foi publicada por seus discípulos em 1983 (pos mortem), como parte integrante dos seis volumes de suas Obras Completas.
} 
sexo, a idade e o grupo social do indivíduo com deficiência. Era constante, no momento da seleção dos informantes, as agentes de saúde se referirem às famílias como: é a família do cego Jeremias ou é a família da mouca. O estigma recai sobre toda a família, constituindo um rótulo, uma marca, sendo fácil encontrála a partir da "deficiência" que ela possui. Essa "anormalidade", se assim se pode chamar, atinge o sujeito em sua totalidade, impedindo que ele cresça de forma natural e satisfatória, afetando, consequentemente, a sua família. Esse fato torna-se bastante evidente quando se analisa a vida do Sr. Jeremias, que, após ficar cego, nunca mais saiu de casa. $\mathrm{O}$ seu contato social, com raras exceções, se restringe a seus familiares; nunca dançou o toré, entretanto lembra-se de uma festa de casamento.

Já na festa de casamento no Bartão. Me botava no cantinho, um ficava ali sentado, quando vão embora me tirava.

Outro fato interessante é que Sr. Jeremias nunca constituiu família. Quando lhe foi perguntado se namorava, ele disse:

Namoro (sorrisos) [...] A sua própria irmã completou: namoro, se achar, ninguém vai querer ele assim.

Tenho vontade de casar. Ainda tava com coragem, mas elas são brava. Eu não vou andar agarrado nelas não. Eu!

Mas ele não quer porque elas não querem. As mulheres só querem safadeza, não querem cuidar, só eu mesmo que sou irmã dele. (Irmã).

A deficiência é considerada como doença: “[...] ninguém vai querer ele assim".

A partir do relato acima, o índio com deficiência, principalmente o cego, está confinado a seu espaço, o que lhe reduz as atividades e oportunidades. Como, então, poderia casar, se não entra em contato com outras pessoas? Os índios com deficiência não possuem incentivo algum para assumir outra postura que não a típica do papel de deficiente. Ao contrário, geralmente eles são programados para ter atitudes e comportamentos dependentes e infantilizados. Não conseguem desenvolver outras possibilidades, percebem-se e são percebidos apenas como deficientes, sendo considerados incapazes, limitados, tendo seus defeitos enfatizados, tornando-se segregados e estigmatizados, não demons- 
trando nenhum interesse ou habilidade para interagir com a sociedade mais ampla.

Diante dessa postura, considera-se incoerente o fato de o Sr. Jeremias ser o mantenedor da casa, fazendo o "alhó" (bolsa). Os familiares pegam o croatá (planta da região) no mato. Ele tira o espinho e faz bolsas, mochilas, etc. E a família vai até a feira vender. A ele é negado o direito de ir vender, pois alegam ser difícil o seu transporte. Segundo González (1995, p. 7), a família e o próprio índio com deficiência caracteriza " $[$... ] a vida como uma perda dolorosa, constituindo-se uma grande lesão ao conceito de si mesmo”. O índio com deficiência encara-se como não sendo capaz de desenvolver nenhuma habilidade sem ser a que já desenvolve, contanto que esteja sentado no canto, não sendo permitido, claro que não explicitamente, sair da situação de "portador" de deficiência, para a construção de uma nova relação com a vida.

Alguns estão satisfeitos com a sua condição de vida, afirmando que é o destino, a natureza, é a vida...

Em alguns casos, a família pode estar atuando como condição agravante da sintomatologia da deficiência, como já dissera González (1995, p. 7): “[...] o que decide a característica da personalidade não é o defeito em si mesmo, senão suas conseqüências sociais.” E essas consequências sociais estão implicadas com uma forte condição de incapacidade.

Alguns índios com deficiência quando estão diante de situações sociais mais amplas, acabam agindo de maneira estereotipada. O processo de comunicação pode ser interrompido, pois desconhecem muitas vezes as estruturas que organizam o processo de comunicação das pessoas com deficiência. Esse seu comportamento reforça mais ainda as representações preconceituosas sobre a deficiência das pessoas com quem eles entram em contato, podendo justificar a segregação.

O desconhecimento da estrutura do defeito mobiliza ações desconfortáveis para o índio com deficiência, familiares e amigos, podendo gerar uma deficiência que não existe, como no caso da tribo. Não se pode ignorar que a situação econômica desse povo é muito precária, o que prejudica ainda mais a participação do índio com deficiência nas atividades da tribo. Quando se pergunta à família do índio com deficiência visual se ele vai para festa, encontra-se como resposta:

Eu nunca levei ele, porque dá muito trabalho. Quando nós vamos com ele pra fazer serviço, a caminhonete tem que trazer nós 
aqui. Às vezes, o toré acontece a noite dia de Sábado. E eu não quero levar ele, porque eu tenho medo de bêbedo no caminho. Sem ele a gente corre. (Irmã de Jeremias).

É evidente que variados problemas políticos, econômicos e sociais recaem sobre os índios hoje. Daí ser possível imaginar o grau de discriminação que sofre o índio com deficiência. Muitas vezes, para a própria família, é difícil entender que o cego é só cego, o surdo é só surdo, e que, independentemente da deficiência, ele é uma pessoa com limitações, mas com imensas possibilidades. Uma deficiência constitui uma incapacidade física somente quando é vista como uma barreira significativa à execução de determinados objetivos, e quase sempre, na tribo, os índios com deficiência são considerados como incapazes. Parece quase simplista explorar os pontos apresentados até aqui. Basta afirmar que a pessoa com deficiência não é incapaz, apenas deficiente.

Entretanto, é difícil afirmar isso sem o conhecimento da estrutura do defeito e, acima de tudo, sem mudança de concepção, o que, no caso das famílias da tribo Pankararé, é difícil, pois são variados os imperativos econômicos, sociais, políticos, etc. É muito difícil aceitar ou julgar tal situação, pois o medo, ignorância, apreensão e preconceito surgirão sob as melhores formas, a maioria delas inconscientes. Aparecerão disfarçados, na proteção paterna, no excesso de preocupação da família, sempre vestidos com o manto do amor.

$\mathrm{Na}$ Tribo Pankararé os rituais acontecem periodicamente. Possuem uma vasta riqueza de conhecimentos relativos a seu ambiente e sua cultura inclui não somente informações sobre diferentes espécies de plantas e animais, seu comportamentos e sua utilidade, mas também informações sobre o modo como esses aspectos se relacionam. Esses conhecimentos dependem do contato com os espíritos, que desempenham um papel fundamental na garantia da reprodução da cultura, do ambiente, enfim, de toda a sociedade.

Portanto toda e qualquer atividade, na tribo, é realizada considerando os encantados. A caça e a plantação são ainda hoje utilizadas apenas para manutenção. Não têm o objetivo de estocar. Os índios plantam para comer amanhã. Por isso, na casa, todos devem ajudar, pois todos vão comer. Até o recém-nascido vai para roça, pois os índios ainda têm o mesmo lema dos seus antepassados: "Aprender, fazendo - aprender para a vida e por meio da vida!" Mas o que acontece quando se foge a essa regra? O que acontece com os índios com deficiência que não podem caçar ou plantar? Quando foi perguntado se os índios com deficiência plantavam ou caçavam, respondiam: 
O cego não trabalha em nada, fica só esperando pelos outros. Não tem nada pra fazer, né. Tem que ter os outros que leva pra algum lugar. (Professora).

O cego não tem condições de como ele rastejar a caça para ele encontrar. (Cacique)

O surdo caça peba. Agora o cego já não faz nada. (Pajé).

Eles [deficientes] trabalham, pois quando nós começamos a nossa comunidade, tinha pessoas que pedia pra ir num animal, só pra participar do trabalho da comunidade. Aí pedia a um companheiro e ia participar. Ele está presente, pois a gente trabalha em comunidade. E aí a gente faz o trabalho dele. (Cacique).

Apesar do reconhecimento de certa participação do índio com deficiência em algumas tarefas, os relatos revelam o desconhecimento da estrutura do defeito, reiterando, para este, o estigma de incapaz. A força desse processo é tão grande e marcante, que, em conversas com os índios com deficiência na tribo, eles próprios demonstram essa concepção internalizada quanto a não poder participar das diversas atividades na tribo. São socializados de maneira estereotipada, de acordo com o rótulo que lhes é outorgado, demonstrando que a sua identidade foi incorporada ao papel de deficiente.

Quem mais nos falou sobre as "intimidades" da tribo foi o Pajé. As outras pessoas entrevistadas sempre mostravam temor, medo. Assim, foi o pajé quem mais relatou a atuação do índio com deficiência na Festa do Amaro, festa da tradição dos índios Pankararés. Quando foi perguntado se o índio com deficiência participava da festa, ele respondeu:

Se as mães fizerem promessa, pode.

Entrevistadora: Ele participa do íntimo da ciência?

Pajé: Não. Só entra mesmo pra pagar a sua promessa.

Entrevistadora: E quem participa do íntimo da ciência?

Pajé: Os homem que é completamente preparado.

Entrevistadora: E quem é completamente preparado? 
Pajé: Todos, se for de maior.

Entrevistadora: Aí o surdo de maior entra?

Pajé: Não. Só se for promessa. Não tem necessidade de entrar. Ele não entende nada. Se entrar, entra só por entrar. Exemplo: Se a mãe ou o pai faz promessa pra ele dizendo que tem que ir até lá participar da ciência, tem que ir. Não tem validade nenhuma pra ele, pois ele não entende.

A partir da análise apresentada, foi necessário também observar se a presença ou não desses índios com deficiência nos rituais faz parte da cultura da tribo. Para isso, foi necessário analisar se os próprios encantados proibiam a sua entrada, como faziam com as mulheres e os índios menores. Assim, perguntouse a alguns entrevistados se os encantados permitiam a presença dos índios com deficiência, sendo obtidas as seguintes respostas:

Isso aí eu não sei não. Porque assim. Eu nunca falei nessa intimidades deles. Tem deles que não gosta muito que pergunte. (Professora).

Não pode confiar em todo mundo (confirmação de todos). (Neta)

Eu não vou responder uma coisa que eu não tenho certeza. (Professora).

Como não foi obtida resposta satisfatória, perguntou-se diretamente ao Pajé:

Eu acho difícil por ele ter vontade de tudo. Eles são iguais a gente. São seres humanos. Pode sentir no coração, mas não pode fazer nada, não pode. Não pode festejar nada. Às vezes, até alimentação pra colocar na colher pra colocar na boca não existe.

No Ponto da ciência, eu acho o seguinte. As mães deveriam se prevenir bastante, isso vem pelas mães. Tem deficiente, o mudo, que é família, tem que ter transpassado, avô, bisavô. As vez muitas vezes, a criança nasce com problema por causa de algum medicamento.

A ciência não impede a participação dos índios com deficiência; entretanto, a própria concepção de incapacidade é que determina a segregação. 
É triste. É triste mesmo. Eu acho que o tanto de gente que o governo tem espalhado nesse mundo poderia ter o lugar certo desse povo. (Pajé).

Em algumas atividades mais gerais da tribo, como o toré, os índios com deficiência participam, embora ficando, em alguns casos, evidente uma situação de pena. Em outros, consideram a participação como natural:

Ele não participa, só quando a gente leva. Quando a gente tem um encontro, a gente leva na cadeira de roda. (Cacique).

Ás vezes tem o prazer de tá ali sentado. O cego escuta os toantes. O surdo e mudo vê o outro pular e dança igual. (Pajé).

Dançam, só assim eles não dançam diretamente! (Professora).

O cego dança não. O cego não faz nada. O cego já tá dançando. O cego só faz comer e ficar parado. (M. J.).

Diante do relatado, em muitos casos, a situação de pena está retratada nas palavras dos entrevistados. É importante afirmar que, a partir do discurso de alguns informantes, fica evidente um empenho pela socialização, embora sob a égide da compaixão. Esse fato confirma que se desconhecem as potencialidades dos índios com deficiência e o quanto eles poderiam desenvolver se fossem dadas oportunidades adequadas no âmbito pedagógico, social, cultural, político e econômico.

Em síntese, a concepção que tem servido de sustentação para a análise da investigação reconhece que o caráter valorativo da deficiência, muitas vezes, determina a postura do índio com deficiência frente à comunidade indígena, ficando difícil não vincular o aspecto descritivo da deficiência à incapacidade. $\mathrm{Na}$ maioria dos casos, o índio com deficiência assume características infantilizadas e dependentes, em função dos discursos marcados por mitos e preconceitos.

Desconhece-se a gênese das deficiências, o que incentiva o estigma de incapaz, determinando e limitando a ação do índio com deficiência nos rituais, na caça, na plantação, o que revela uma postura de submissão frente às contingências sociais. O estigma embutido nestes índios determina papéis referentes às suas habilidades, limitando o seu desenvolvimento biopsicossocial.

De um jeito ou de outro, o que define a relação com o índio com deficiência não é o defeito em si, mas a "incapacidade" que lhe é atribuída, determinan- 
do a sua forma de ser, pensar e agir. Isso graças ao desconhecimento das teorias que podem contribuir com um maior "ajustamento" dos deficientes no seu meio social.

Diante do relato acima considera-se longo o percurso para a inclusão, pois como enfatiza Pessotti (1984) temos que trilhar o caminho da superstição à ciência, sem invadir a cultura do índio fazendo-o ressignificar conceitos, pois muitas vezes, o processo de discriminação acontece em função do desconhecimento da estrutura do defeito, sendo necessário buscar o conhecimento científico para articulá-lo com o conhecimento comum. Daí deixamos a seguinte questão:

A organização de um programa de formação para os da Tribo Pankararé sobre pressupostos epistemológicos da deficiência poderá contribuir para desmistificação do estigma de incapaz que é legado a pessoa com deficiência ou estará invadindo a cultura de um povo tão singular?

\section{REFERÊNCIAS}

AMARAL, L. Pensar a diferença/deficiência. Brasília: CORDE, 1994.

ASSOCIAÇÃO NACIONAL DE APOIO AO ÍNDIO DA BAHIA. Coordenadoria Ecumênica de Serviços. Cartilha. 2. ed. Salvador: [s.n.], 1992.

BANDEIRA, F. P. S. de F. Etnobiologia Pankararé. 1993. Monografia (Bacharelado em Biologia) - Instituto de Biologia, Universidade Federal da Bahia, Salvador, 1993.

DUARTE, N. Educação escolar, teoria do cotidiano e a Escola de Vygotsky. Campinas: Autores Associados, 1996.

FERNANDEZ, F. A organização social dos Tupinambás. São Paulo: Instituto Progresso Editorial, 1959.

GLAT, R. A integração dos portadores de deficiência: uma questão psicossocial. In: REUNIÃO ANUAL DA SOCIEDADE DE PSICOLOGIA DE RIBEIRÃO PRETO, 24., 1994, Ribeirão Preto. Anais... Ribeirão Preto: SBP, 1994. Mesa redonda.

. Somos iguais a você: depoimentos de mulheres com deficiência mental. Rio de Janeiro: Agir, 1989.

GOFFMAN, E. Estigma: notas sobre a manipulação da identidade deteriorada. 3. ed. São Paulo: Zahar, 1982.

GONZÁLEZ, M. T. Família y discapacidad: análisis psicosocial. La Habana, 1995. Mimeografado.

MAIA, S. M. Os Pankararé do Brejo do Burgo: campesionato e etnicidade. 1992.

Monografia (Bacharelado em Antropologia) - Faculdade de Filosofia e Ciências Humanas, Universidade Federal da Bahia, Salvador, 1992. 
OMOTE, S. A integração do deficiente: um pseudo problema. In: REUNIÃO ANUAL DA SOCIEDADE DE PSICOLOGIA DE RIBEIRÃO PRETO, 24., 1994. Anais... Ribeirão Preto: SBP, 1994.

PESSOTTI, I. Deficiência mental: da superstição à ciência. São Paulo: T. A. Queiroz, 1984.

VIGOTSKI, L. S. A formação social da mente. São Paulo: Martins Fontes, 1984. Pensamento e linguagem. São Paulo: Martins, 1993. . Fundamentos da Defectologia. In: Obras Completas. 2. ed. La

Habana: Pueblo Y Educación, 1997. 


\section{COMPREENDENDO O TERRITÓRIO-LUGAR COMO PONTO DE PARTIDA PARA A INCLUSÃO SOCIAL}

Cleverson Suzart

Fernanda Ma Gonçalves Almeida

Mary Arapiraca

Miguel Bordas

\section{DEFININDO TERRITÓRIO-LUGAR}

Com o intuito de refletir a respeito do processo de inclusão social e, consequentemente, educacional faz-se necessário levantar alguns questionamentos que perpassam o mundo contemporâneo, ou melhor, o mundo dito globalizado. É possível refletir sobre o processo de inclusão social sem uma leitura crítica do processo de globalização e sua inserção nos territórios-lugares? Como compreender os territórios-lugares a partir de uma perspectiva inclusiva? E o que é o lugar? A compreensão de que no lugar-território nascem múltiplos saberes e conhecimentos orgânicos seria um caminho para o processo de inclusão social?

Uma primeira reflexão a ser desenvolvida, para o esboço das respostas levantadas, tem como objetivo principal discutir a definição de lugar. É importante compreender que a lógica da transnacionalização neoliberal da nova ordem capitalista trabalha com o intuito de destruir o lugar, que passa a assumir a configuração do olhar aligeirado do estrangeiro. Daí a urgência de seguir adiante na tentativa de compreender o que de fato venha a ser o lugar.

A conceituação do lugar passa, em primeira instância, pela reflexão do território e sua configuração nos dias atuais. Em diálogo com Santos (2005), o 
que se escuta do autor é que hoje se vive com uma noção de território herdada da Modernidade incompleta, bem como de seu legado repleto de conceitos puros, que foi atravessando os séculos praticamente sem modificações. Santos (2005) evidencia que, o que faz do território o objeto da análise social é o seu uso, e não o território em si. Desta forma, a nosso ver, não é a demarcação das fronteiras territoriais concretas e imaginárias que implica em análises dos seus acontecimentos, mas sim, toda trama de existência que dentro de suas linhas vão cotidianamente sendo tecidas.

Continuando sua reflexão a respeito do território, Santos (2005) evidencia que se tem caminhado ao longo dos séculos, da antiga comunhão individual dos lugares com o Universo à comunhão hoje global. Esse movimento vai efetivar-se com a interdependência universal dos lugares, traduzindo na nova realidade do território. Na constituição dos territórios, o Estado-Nação traduz-se em um marco que introduz a noção jurídico-política do território, que vai derivar do conhecimento e da conquista do mundo, desde o Estado Moderno e o Século das Luzes à era da valorização dos recursos naturais. Assim, para Santos (2005), nesse processo, o Estado é o definidor dos lugares, sendo o território a sua base, melhor, seu fundamento. É evidente que o território que, como visto era o fundamento do Estado, também por ele era moldado, ou seja, o território representava as conquistas e derrotas do Estado em constituição e modificação. No entanto, nos tempos atuais, Santos (2005) indica que se vive uma dialética do mundo concreto, onde se evoluiu da noção, tornada antiga, de Estado Territorial para uma noção pós-moderna de transnacionalização do território.

O que se assiste nesse fim e início de milênios com esse movimento de transnacionalização do território é a constituição de territórios com a mesma face bizarra do sorridente e famigerado capitalismo, que na versão transnacional imprime seu sorriso uniformizador, obrigando a todos em todos os lugares a copiar sua expressão facial de felicidade, como se de fato essa alçasse a todos em todos os lugares por onde passa. Na verdade, o que acontece é que os povos dos diversos territórios que têm tal ilusão assustam-se ao quando se deparam com a imagem refletida em seus espelhos históricos, que mostram que a verdadeira imagem construída com a transnacionalização é a face da miséria e da dor e da inevitável exclusão social.

É evidente que esse processo não está definido para todo sempre, pois ele pode vir a se modificar a qualquer momento, basta a clareza de que de repente, como diria Gilberto Gil, as águas ficam turvas, portanto, tudo está por um fio em devir nesse tempo-instante histórico. Tal compreensão evidencia também 
que nada é totalmente hegemônico. Como bem aponta Santos (2005), assim como antes nem tudo era território estatizado, nos dias atuais nem tudo está transnacionalizado. O que se escuta com clareza na fala do autor, é a possibilidade concreta da re-existência resistente dos tempos-espaços territoriais ao projeto mundializador da perversa globalização.

Feita essa reflexão, pulsa o questionamento: como se forma o território nos dias atuais imersos em um perverso processo de globalização hierarquizante? Santos (2005) argumenta que podem ser formados tanto por lugares contíguos quanto por lugares em rede. No entanto, conforme o autor, ambos os lugares contínguos e os lugares em rede são os mesmos lugares, os mesmos pontos, que contêm simultaneamente funcionalizações diferentes. Tais funcionalizações podem mesmo ser divergentes ou opostas. A noção do acontecer simultâneo desses diversos lugares, a nosso ver, demarca a complexidade de análise do território e, portanto, do lugar. Mas, ao mesmo tempo, implica em uma leitura mais apurada do território e do lugar no sentido de esclarecer o que pode e precisa ser potencializado em cada tempo-espaço-lugar.

Nessa perspectiva analítica, Santos (2005) evidencia que há um conflito que vem se agravando entre o que denomina de espaço local, que se traduz em um espaço vivido por todos os vizinhos, e um espaço global, que é habitado por um processo que se desenvolve pautado na racionalização e em um conteúdo ideológico de origem distante que chegam a cada lugar com o estabelecimento de normas e objetos para servi-los. Diante desse conflito, o autor esclarece ser de fundamental importância o retorno à noção de espaço banal, ou seja, espaço de todos. A retomada de tal noção, a nosso ver, é de extrema importância, pois, o olhar para o território, o lugar, deve ter como prevalência o olhar para os acontecimentos que pertencem a todos, pois aí se encontra a potência do lugar. A afirmação da noção de espaço banal, espaço de todos precisa, portanto, contrapor a noção de redes, ou seja, o território daquelas formas e normas a serviço de alguns.

O que se escuta na voz acima é que mais do que nunca é imprescindível mergulhar no território, ou melhor, no território demarcado pelo acontecimento da vida cotidiana, onde todos podem e são autores-atores de suas vidas. Esse efetivo mergulho pode possibilitar a potencialização da re-existência do lugar ao processo mundializador das redes mundiais, que se ramificam para controlar e desterritorializar os territórios re-existentes. É evidente que se o controle de tais redes está em mãos do capital internacional, que trabalha com a lógica da transnacionalização de todos os territórios, o que se vai assistir é uma centraliza- 
ção do comando mundial sobre tais redes. É aí que a lógica do conhecimento dito universal passa a ser uniformizador, ou melhor, vai territorialmente se instaurando como única possibilidade. Assim, a aranha-mundi que tece as teias, melhor redes, é uma espécie de viúva negra, que ao tocar os territórios-lugares os desfazem, desmontando a teia e trama de relações solidárias, que são cotidianamente tecidas por todos. É a concretização da inclusão na exclusão social desumana e voraz que tem como premissa básica a dominação.

Seguindo a configuração acima, o território assume uma característica bastante peculiar na chamada democracia de mercado. Ocorre que, como aponta a mesma fonte, o território passa a ser o suporte de redes, que tem o papel de transportar regras e normas utilitárias. Essas são parciais, parcializadas, e consolidam as verticalidades, reforçando o poder hegemônico e a lógica da desagregação. É óbvio que com esse movimento, as horizontalidades passam a ser enfraquecidas, ou seja, perdem força e potência para resistência a esse desumano processo. Assim, é o território o tempo-espaço ou o espaço-tempo, onde efetivamente se dá a luta das diversas forças ideológicas que trabalham tanto para a construção de uma vivência múltipla, plural, diversa e em prol da humanidade, quanto para a consolidação de uma única forma de estar no mundo. Essa última forma de ocupação do território tem como parâmetro a escala do lucro-máquina: automóvel, avião, computador e não do ser humano e suas potencialidades ontológicas. É aí na escala da máquina que se vê a constituição do tempo extra-território, atropelando o tempo real das diversas temporalidades espaciais próprias.

Mas, como evidencia Santos (2005), o lugar independente do seu tamanho, dimensão representa a possibilidade da resistência da sociedade civil. No entanto, aponta o autor, que nada impede e, como se percebe, é fundamental, que se aprenda formas de se estender essa resistência às escalas mais altas. A resistência a esse processo necessita de ação cotidiana e articulada, para que possa ser extensiva a outras esferas do processo social. E isso somente é possível, esclarece Santos (2005), na insistência indispensável de conhecimento sistemático da realidade, que deve ter como base o tratamento analítico e fundamental do território. O mergulho na realidade demanda vivência do lugar, com-vivência com o lugar, leitura interna a partir das ferramentas de análises cotidianas que são chaves para o seu entendimento e afirmação. É com essa ação que está a potência trans-formadora do lugar, é nesse e desse movimento em carrossel labiríntico e em caleidoscópio que se vê a constituição da carne e da epiderme do território-lugar. É aí que está toda a força promotora da inclusão social. 
Como foi visto na fala de Santos (2005), o que está em jogo é a valorização do território a partir de sua dinâmica própria. E a valorização dessa dinâmica própria passa pelo efetivo conhecimento do que venha a ser território-lugar, ou seja, quais as suas potencialidades e possibilidades de enfrentamento ao processo de mundialização em curso. Portanto, é imprescindível um retorno ao lugar, às lógicas e aos imaginários que se constroem nas teias das realidades vividas por todos.

\section{O LUGAR E A MATERIALIZAÇÃO DA INCLUSÃO}

Diante da tensão em relação ao território-lugar criado a partir do perverso processo de globalização, faz-se necessária uma reflexão mais ostensiva a respeito do papel do lugar no processo de inclusão. Daí tentar-se-á, a partir de agora, compreender melhor a definição desse espaço tão fundamental nos dias atuais.

A reflexão até aqui desenvolvida aponta para uma leitura mais concreta e contundente do que venha a ser o lugar em toda a sua complexidade. Um aspecto pode e deve trazer benefícios para tal compreensão. Tal aspecto diz respeito à dimensão da história, que analisado por Carlos (1996), é vista como algo que entra e vai se realizar cotidianamente, vindo a estabelecer um vínculo entre o movimento de dentro e o de fora. Essa dimensão, segundo a autora, instala-se no plano do vivido, produzindo o conhecimento-reconhecido, ou seja, é ali, no lugar, onde a vida se desenvolve em todas as suas dimensões e, possibilidades em potência. Segundo a autora, atentar para a dimensão da história significa também pensar a história particular de cada lugar se desenvolvendo, melhor, se realizando a partir de uma cultura/tradição/língua/hábitos que nascem e são próprios, que vão sendo confeccionados ao longo da história daquele tempoespaço-lugar e o que vem de fora. Assim, nessa perspectiva, é pensar a dinâmica da história do lugar com o que está em curso no processo de mundialização.

Nessa perspectiva, é importante o que de fato seja o lugar, ou melhor, como ele se configura e se materializa. Segundo Carlos (1996), o lugar pode ser traduzido como a base de produção da vida, podendo vir a ser analisado pela tríade habitante-identidade-lugar. A cidade é um claro exemplo do que venha a ser um lugar, pois vai se produzir e revelar no plano de vida do sujeito, do indivíduo a ele pertencente. É a confluência dos acontecimentos do lugar no indivíduo e do indivíduo no lugar. Essas relações que são cotidianas apresentam-se através das relações que os indivíduos mantêm com os espaços habita- 
dos, ou seja, como o indivíduo usa esses espaços, ou melhor, como ele os compreende, sejam nas mais diversas formas, nas condições banais, no secundário, no acidental.

Acontece que é o espaço possível de ser sentido pelo sujeito, por ele pensado, apropriado e vivido através do corpo. É aí, no corpo, na forma de falar, de andar de expressar-se para o mundo, que o lugar se materializa, ou seja, é no sentido que o homem constrói e se apropria do mundo que está situado o lugar, melhor, é onde se encarna o lugar e toda a sua dinâmica cultural e material. O corpo que se expressa através do olhar, da voz, dos gestos, do jeito de gesticular expressa a intersubjetividade cultural materializada coletivamente nos atores do lugar. É nesse aspecto do lugar que se encontra a constituição da carne do lugar de onde nasce toda a potência solidária e todos os conhecimentos e saberes orgânicos produzidos na com-vivência inclusiva.

\footnotetext{
Motorista de ônibus, bilheteiros são conhecidos-reconhecidos como parte da comunidade, cumprimentados como tal, não simples prestadores de serviço. As casas comerciais são mais do que pontos de troca de mercadorias, são também pontos de encontro. (CARLOS, 1996, p. 20).
}

A fala da autora aponta que o que caracteriza o lugar são as suas relações cotidianas regidas sob a ótica da com-vivência de grupos humanos agregados a partir do sentimento de pertencimento de todos os sujeitos envolvidos na trama daquele tempo-espaço em devir. Dessa forma, a autora pontua que o lugar jamais poderia vir a ser a metrópole, ou mesmo a cidade lato sensu, ao menos que venha a ser a pequena vila ou cidade, que é vivida, conhecida, reconhecida em todos os cantos. O lugar é, sob esse olhar, o tempo-espaço onde estão demarcados os passos das pessoas que o habitam, ou seja, é o bairro, é a praça, é a rua, enfim, é o território da vivência, onde há conhecimento e reconhecimento de todos por todos que ali habitam aquele ambiente.

\section{A DIFERENÇA COMO FUNDANTE PARA CONFIGURAÇÃO DO LUGAR EFETIVAMENTE INCLUSIVO: algumas considerações (in)conclusivas}

Sem dúvida, o território-lugar é o ponto de partida para uma inclusão efetivamente solidária. É nele que nascem todas as potências de valorização da vida e, portanto, todos os saberes-conhecimentos necessários à sua manuten- 
ção. Daí a importância vital do conhecimento da tecnociência, construído sob a égide da epistemotecnolucrologia, não ser visto como única possibilidade de explicação e aplicação na vida cotidiana. É aí, a partir do lugar, que se pode pensar em outras matemáticas, outras físicas, outras linguagens, outras químicas, enfim, em outros saberes que tenham a vida como fundante, em outros saberes que não se construam de forma compartimentalizada, que brotem da vida na sua real complexidade, ou seja, na complexidade de cada tempo-espaço. É na diferença como fundante que se pode ter a compreensão do que possa ser pensado como lugar e o que, de fato, provém do mesmo como conhecimento-saber múltiplo, plural e diverso.

É no lugar e a partir dele que se vê brotar as diferenças que singularizam os grupos humanos e suas formas de estar no mundo. A diferença aqui é vista como ontológica diferindo, portanto, do discurso da igualdade, que tem como essência a igualdade na igualdade. Tal discurso, que tem como fundamento básico que todos são iguais, acaba por legitimar a atitude-discurso de um padrão de sociedade, um padrão de comportamento, uma única forma de estar no mundo, enfim, uma única forma de progresso, de desenvolvimento que desencadeia o perverso processo de exclusão social.

O discurso da igualdade na igualdade não comporta a diferença, o plural, o alternativo, porque não tem como fundamento os diversos acontecimentos promovidos pelos atos humanos que têm à frente o abismo da incerteza do acontecer cotidiano da existência. É no discurso da igualdade na igualdade que se vê montada a estratégia da construção de um único acontecer no mundo, ou seja, da conversão perversa do planeta em um único lugar. Assim, as diferenças ontológicas são vistas como um castigo divino, o paraíso somente será atingido quando se efetivar a igualdade na igualdade. Para que isso possa vir a acontecer, a igualdade deve ser programada, prevista, matematicamente construída a partir de uma engrenagem astutamente montada na lógica da paralisação de acontecimentos que possam vir a colocar em xeque tal concepção.

Contrariamente a paralisante concepção que vê a igualdade na igualdade, a concepção da igualdade na diferença tem como fundante a própria diferença e não a igualdade. Como apontam Serpa e Santos (2000), os seres humanos são iguais porque são diferentes, ou seja, o que constitui a igualdade do ser humano é a sua diferença, é aí que está a potência do acontecer e viver dos seres humanos. É essa potência dos seres humanos, ou melhor, é a igualdade na diferença que proporciona a riqueza da vida, que gera outras formas de existir e estar no mundo. É na multiplicidade dos acontecimentos cotidia- 
namente incertos que está a possibilidade de outras lógicas de mundo, de outras formas de cultuar a plenitude da vida. É aí que o lugar-mundo se configura como lugares-mundos, que ainda resistem e re-existem ao projeto de mundialização em curso.

A diferença é um vetor atômico-quântico por ter todas as possibilidades em potência. Possibilidades essas, que estão no tempo relacional, no tempo que brota de cada lugar-espaço, que não é único como quer a mundialização. As diferenças produzem assim tempos múltiplos, que têm como essência a incerteza dos acontecimentos, a instabilidade do hic et nunc, ou seja, do aqui e agora. Assim, não há, nem pode haver um padrão de existência e é essa não possibilidade da existência de um padrão mundial que se instaura a força das diferenças e a necessidade da afirmação das mesmas. É a partir da igualdade na diferença que está a potência do lugar, melhor, a potência de todos os lugares, de todas as cores, de todas as tribos, pois os rumos aí estão abertos, indefinidos, não-programados e não-programáveis, pois encontram-se na eterna tensão entre o lugar-instituído e o instituinte-lugar, ou melhor, no que já está consolidado e agrega as pessoas em prol de um sentimento de pertença e inclusão solidária, e no que está em movimento, através do vetor transformador da vida cotidiana, que está inevitavelmente em mudança.

É nessa configuração dada pelo movimento da vida que circulam em carrossel atômico todos os saberes-conhecimentos que podem vir a promover a construção da solidariedade inclusiva do lugar que se encontra nas relações horizontais que o compõem. Relações horizontais essas, que constroem e reforçam a com-vivência de todos com todos, do sujeito-sujeito, do Eu-com-ooutro, enfim, do mundo do indivíduo e sua subjetividade com o mundo de todos e o encontro de todas as subjetividades desembocando nas intersubjetividades culturais dos lugares. É nesse sentido que se vê com clareza a necessidade de uma outra postura para o fazer ciência e para o fazer pedagógico, uma postura que possa estar atenta a toda potência do lugar, dos atos de solidariedades do mesmo e, consequentemente, de todos os saberesconhecimentos provenientes da potência das diferenças ontológicas, que são a verdade e a materialização da carne do lugar que tem como tecido a efetiva e solidária inclusão social.

É óbvio que a reflexão aqui desenvolvida precisa ser vista como uma nascente em nascimento. Ela é, na verdade, uma breve tentativa de indicar possibilidades, por isso deve ser pensada como potência em ato, como o nascer do sol 
do verão da velha São Salvador e do inesperado talvez que está sempre por acontecer.

\section{REFERÊNCIAS}

AUGÉ, Marc. Não-lugares: introdução a uma antropologia da supermodernidade. Campinas: Papirus, 1994.

CARLOS, Ana Fani Alessandri. O lugar no/do mundo. São Paulo: Hucitec, 1996.

DELEUZE, Gilles. Diferença e repetição. Rio de Janeiro: Graal, 2006.

SANTOS, Milton. Da totalidade ao lugar. São Paulo: Edusp, 2005.

SERPA, Felippe Perret; SANTOS, Nalva. A diferença como fundante: convivência universidade-comunidade. 2000. Disponível em: <http://www.faced.ufba.br/ rascunho_digital>. Acesso em: 16 out. 2009. 



\section{CONVIVENDO COM A DIVERSIDADE:}

a inclusão escolar da criança com deficiência intelectual

Cristiane Teixeira Sampaio

Sônia Maria Rocha Sampaio

\section{INTRODUÇÃO}

A opção pela escola inclusiva foi oficialmente assumida por diversos países, através da Declaração de Salamanca (1994). O reflexo deste movimento pela inclusão está visivelmente expresso na legislação brasileira, que se posiciona pelo atendimento aos alunos com necessidades educacionais especiais preferencialmente em classes comuns da escola, em todos os níveis, etapas e modalidades de educação e ensino (BRASIL, 1999).

Entretanto, apesar da justiça da proposta de não se excluir uma criança do acesso à educação por sua singular condição física ou mental, o que percebemos é um total despreparo da sociedade em geral e das escolas em particular para empreender a tarefa de transformação que a inclusão exige.

Diante das constantes referências às dificuldades de implantação de um projeto inclusivo, é importante considerar não só os entraves político-pedagógicos, mas também as vivências estimulantes e frustrantes surgidas no cotidiano das relações estabelecidas entre os participantes da comunidade escolar.

Assim, visando abordar o tema da inclusão dando vez e voz aos atores sociais a quem foi atribuído colocarem-na em prática, realizamos um estudo que buscou descrever e analisar as experiências de professoras acerca da inclusão 
de crianças com deficiência intelectual em classes regulares de uma escola pública do ensino fundamental. Procuramos assinalar os possíveis aspectos subjetivos envolvidos na prática docente com o aluno com deficiência e suas consequências para a implantação da proposta inclusiva. Além disso, propomos identificar o que elas consideravam como fatores situacionais facilitadores (ou dificultadores) para a viabilização desta proposta pedagógica no contexto da educação pública.

\section{INCLUSÃO X INTEGRAÇÃO}

Por volta de 1960, a institucionalização das pessoas com deficiência começou a ser criticamente examinada, baseando-se em dados que revelavam sua ineficiência para favorecer a preparação ou a recuperação delas para a vida em sociedade. Assim, a contemporaneidade produziu o confronto entre dois eixos conceituais em relação à educação da criança com deficiência: a integração e a inclusão.

Tanto a integração como a inclusão propõem a inserção educacional da criança com deficiência, só que a inclusão o faz de forma mais radical, completa e sistemática. Trata-se de uma concepção político-pedagógica que desloca a centralidade do processo para a escolarização de todos os alunos nos mesmos espaços educativos.

Para uma efetiva implementação do modelo inclusivo na educação, faz-se necessária uma profunda reorganização escolar, que requer, entre outras medidas, a redução do número de alunos por turma, nova infraestrutura e a construção de novas dinâmicas educativas. A complexidade envolvida neste processo reforça a importância da formação dos professores, que se torna um fator-chave para propiciar as mudanças exigidas pela educação inclusiva (ARANHA, 2000, 2001; GLAT; MAGALHÃES; CARNEIRO, 1998; MANTOAN, 1997, 2000; MARCHESI; ECHEITA; MARTIN, 1995; MARTINS, 2002; TESSARO, 2005, entre outros).

\section{REFERENCIAIS TEÓRICOS}

A complexidade das questões educativas, em geral, e da educação inclusiva, em particular, justifica a adoção de uma abordagem de inspiração multirreferencial, que propõe a leitura plural da realidade fazendo uso da concorrência de referências distintas que devem guardar suas respectivas indepen- 
dências enquanto contribuições à compreensão polissêmica do objeto seja ele prático ou teórico (SAMPAIO, 2002).

Para subsidiar nossas reflexões, reportamos-nos às contribuições da teoria histórico-cultural de Vygotsky e da psicanálise, buscando sua articulação com a questão da educação inclusiva. Em relação à psicologia histórico-cultural, destacamos três aspectos: a importância da heterogeneidade na sala de aula, o papel mediador do professor e a abordagem de Vygotsky (1997) sobre a questão da deficiência através da defectologia.

Quanto à psicanálise, apresentamos possíveis interlocuções com o campo da educação, através dos conceitos de narcisismo e transferência (FREUD, 1914, 1933/1990; KUPFER, 1997, 2001, entre outros). Focalizamos nossa atenção sobre os efeitos psíquicos que a deficiência pode causar tanto na pessoa que a possui, como naqueles com quem ela se relaciona. As evidências da falha no outro abalam psiquicamente os seres humanos, pois a pessoa com deficiência converte-se na prova incontestável da fragilidade do ser humano (AMIRALIAN, 1997; CARPIGIANI, 1999; MOLINA, 2001).

\section{CAMINHOS METODOLÓGICOS}

A estratégia de pesquisa escolhida foi o estudo de caso de cunho etnográfico. As participantes foram oito professoras de uma escola pública regular da rede municipal.

Após um período de observação, etapa importante para traçar linhas de ação e reduzir a distância entre a pesquisadora e os participantes, iniciou-se as entrevistas semi-estruturadas. Para a análise dos dados foi utilizada a técnica de análise de conteúdo temática. As categorias foram sendo construídas em um processo de retorno constante aos dados, até chegarmos a uma proposta final. Trechos e expressões retiradas literalmente das entrevistas estão destacados com aspas.

\section{RESULTADOS E DISCUSSÃO}

O trabalho da análise dos dados nos levou a estabelecer cinco categorias: como as professoras qualificam e problematizam a inclusão no cotidiano da escola; sendo um professor inclusivo; paradoxos da inclusão; sentimentos despertados pela convivência com a deficiência e formação para a educação inclusiva. 
A inclusão da criança com deficiência intelectual na escola regular é considerada, pelas professoras, como uma proposta justa, uma "evolução da sociedade", como disse uma delas e, igualmente como oportunidade de desenvolvimento.

Há um reconhecimento de que a educação inclusiva está pautada em princípios educativos. No entanto, apesar de conhecerem as justificativas pedagógicas para a implementação da educação inclusiva, algumas professoras deixaram claro o caráter obrigatório, legal, para aceitarem os alunos com deficiência.

De forma unânime, as professoras afirmaram que se sentem despreparadas para trabalhar com essas crianças. Além disso, o grande número de alunos na sala também foi mencionado como um óbvio fator dificultador da inclusão.

O reconhecimento dos benefícios da escola inclusiva para a criança com deficiência em termos de socialização e autonomia é quase uma unanimidade nos relatos. Outra consequência positiva da inclusão ressaltada por elas é a oportunidade criada pela interação entre a criança com e sem deficiência, para que sejam trabalhados não só questões relativas a diferenças, direitos e deveres, mas também o incentivo ao trabalho em grupo.

As participantes indicaram quatro eixos que caracterizam a postura de um professor inclusivo: valorização da singularidade do aluno e respeito a seu ritmo, ressaltando suas possibilidades, e não apenas sua deficiência; atenção ao vínculo professor-aluno, uso adequado e não estigmatizante do diagnóstico e a presença de um desejo de aprender vibrante no professor, a fim de que esteja aberto para buscar alternativas de intervenção diante da inegável dificuldade em aprender dos alunos com deficiência.

Entretanto, ao lado do discurso sobre as possibilidades de uma prática pedagógica inclusiva, também encontramos exemplos de estratégias inadequadas e dúvidas sobre como lidar com essas crianças que também apontam para concepções equivocadas sobre o que sejam estratégias de cunho inclusivo.

A preocupação de algumas entrevistadas com a "professora do ano seguinte", aquela que daria continuidade ao trabalho iniciado por elas, demonstra a importância da postura pessoal do professor ante a inclusão, uma vez que a escola parece ter uma proposta inclusiva, ainda que muitos não a adotem.

Não foi incomum identificarmos uma ambivalência no discurso das professoras sobre o tema: afirmam aceitar a inclusão, mas fazem a ressalva "a depender do caso." O comprometimento intelectual severo e o comportamento 
agressivo são considerados ou, ao menos sinalizados, como podendo ser motivo para negar o acesso da criança com deficiência à escola.

Constatamos então que, apesar de admitirem os benefícios da inclusão, as professoras são enfáticas ao apontarem as dificuldades para receber os alunos com deficiência intelectual. Para elas, o grande entrave é se há ou não o "avanço cognitivo".

De acordo com o foco de nosso estudo, incentivamos as professoras a falarem dos sentimentos vivenciados na convivência com a criança com deficiência e as reflexões pessoais que esta experiência lhes suscitou.

Um dos sentimentos mencionados pelas professoras foi o medo, relacionado a uma reação "natural" diante de situações novas; a deficiência é percebida como algo desconhecido, que pode deixar o professor "assustado" e despertar a tão conhecida resistência às mudanças. Outra referência ao medo surgiu diante do receio de uma possível reação agressiva de uma aluna, na qual a entrevistada associa deficiência mental e agressividade, como se uma justificasse a outra.

Quanto a essas possíveis reações de angústia diante da deficiência, o professor é afetado como qualquer outra pessoa inscrita em uma sociedade que cultua a beleza física e o ideal de completude. Porém, ao professor, é atribuída a tarefa de ensinar a essas crianças, baseado numa visão de educação que valoriza muito a aprendizagem acadêmica e o avanço cognitivo.

As professoras parecem defrontar-se com um sentimento de fracasso ao constatar que o conhecimento que possuem não se aplica a estes alunos que encarnam a radicalidade da diversidade. Elas falam desse incômodo de diferentes formas: "frustração" por não constatarem avanço cognitivo; necessidade de que "percam" a fantasia de que as crianças com deficiência aprendam do mesmo jeito; "professor é ansioso, quer resultado."

Entretanto, é interessante ressaltar que também colhemos depoimentos falando que o trabalho junto a essas crianças também pode ser uma boa oportunidade de obter gratificação com a profissão. As professoras constatam a importância de sua mediação para o desenvolvimento da criança em termos de comportamentos adequados à convivência social e, a depender do caso, também progressos, ainda que mais lentos, rumo à alfabetização.

Quanto à questão da formação dos professores para educação inclusiva, dois grandes temas caracterizam a opinião das participantes sobre o assunto: tanto elas demandam uma formação específica, isto é, informações gerais sobre as deficiências, quanto salientam a importância de uma formação que desenvol- 
va uma "visão da inclusão", ou seja, a aceitação das diferenças, o respeito à singularidade.

Este conhecimento sobre as características das deficiências pode provocar uma visão generalista que desconheça as singularidades de cada caso. Por outro lado, como o desconhecimento alimenta o preconceito, parece-nos indicado constar informações sobre as deficiências num programa de formação, visando questionar ideias preconcebidas e tão comuns em relação a esta população.

Porém, além destas discussões sobre conhecimento técnico e concepções pedagógicas, acreditamos que toda a mobilização afetiva provocada pela inclusão da criança com deficiência nas escolas exige que uma outra perspectiva deva ser considerada na formação para a educação inclusiva.

Constatamos o quanto pode ser desorganizador para a escola a chegada dessas crianças "diferentes" e que é notório o sentimento de desamparo na fala das professoras entrevistadas, daí a importância de implantar propostas de formação que também se preocupem com um acolhimento das dificuldades encontradas pelos professores (BASTOS, 2005; VOLTOLINI, 2005).

\section{CONSIDERAÇÕES FINAIS}

Evidentemente que a proposta de inclusão envolve a sociedade como um todo e precisa de condições objetivas para que seja colocada em prática, entre elas, a valorização da educação e, consequentemente, o reconhecimento da importância do trabalho do professor, mediante formação adequada, reestruturação da carreira docente e melhores salários. Entretanto, consoante com os objetivos deste estudo, buscamos ressaltar os componentes subjetivos da prática docente, o que não significa dissociá-los das condições sócio-históricas que a envolvem.

Observamos que não se trata apenas de os professores conhecerem mais sobre deficiências ou como ensinar a esses alunos, mas de criar espaços para que reflitam como são afetados por esta convivência. Assim, enquanto as professoras falam de um despreparo de ordem pedagógica, salientamos que também está em jogo um despreparo psíquico para lidar com a realidade, às vezes tão difícil de aceitar, que a deficiência traz, justamente, por denunciar os limites do corpo a que todos nós estamos sujeitos, como também, no caso da prática docente, apontar os limites de uma prática pedagógica que privilegia as aquisições cognitivas. 
Trabalhar com crianças diferentes da norma exige do professor novos posicionamentos, não só no plano pedagógico, mas, igualmente, no plano ético. Portanto, acreditamos que o acolhimento e a escuta da angústia dos professores que convivem com a diversidade, em suas mais variadas acepções, deve ser um aspecto fundamental de uma formação para a educação inclusiva.

\section{REFERÊNCIAS}

AMIRALIAN, M. L. T. M. O psicólogo e a pessoa com deficiência. In: BECKER, E. et al. Deficiência: alternativas de intervenção. São Paulo: Casa do Psicólogo, 1997.

ARANHA, M. S. F. Inclusão social e municipalização. In: MANZINI, E. J. (Org.). Educação especial: temas atuais. Marília: Unesp - Marília Publicações, 2000, p.1-10.

- Paradigmas da relação da sociedade com as pessoas com deficiências. Revista do Ministério do Trabalho, v. 11, n. 21, p.160-173, mar. 2001.

BASTOS, M. B. Inclusão escolar: inclusão de professores? In: COLLI, F. A. G. (Org.). Travessias inclusão escolar: a experiência do grupo ponte pré-escola terapêutica lugar de vida. São Paulo: Casa do Psicólogo, 2005. p. 133-147.

BRASIL. Ministério da Educação. Parâmetros curriculares nacionais. Adaptações curriculares. Estratégias para educação de alunos como necessidades educacionais especiais. Brasília, 1999.

CARPIGIANI, B. A leitura da deficiência sob a lente da resistência. Psicologia: teoria e prática, São Paulo, v. 1, n. 2, p. 20-26, 1999.

DECLARAÇÃO de Salamanca. Sobre princípios, políticas e práticas na área das necessidades educativas especiais. 1994. Disponível em: < http://portal.mec.gov.br/seesp/arquivos/pdf/ salamanca.pdf $>$. Acesso em: 21 out. 2009.

FREUD, S. Algumas reflexões sobre a psicologia do escolar. In: . Obras Psicológicas Completas. Tradução de J. Salomão. Rio de Janeiro: Imago, 1990. Edição standard brasileira. v. 13 .

. Sobre o narcisismo: uma introdução. In: In: . Obras Psicológicas Completas. Tradução de J. Salomão. Rio de Janeiro: Imago, 1990. Edição standard brasileira. v. 14.

. Novas conferências introdutórias sobre a psicanálise: explicações, aplicações, orientações. In: In: Obras Psicológicas Completas. Tradução de J. Salomão. Rio de Janeiro: Imago, 1990. Edição standard brasileira. v. 22.

GLAT, R.; MAGALHÃES, E.; CARNEIRO, R. Capacitação de professores: primeiro passo para uma educação inclusiva. In: MARQUEZINE, M. C. et al. (Org.). Perspectivas multidisciplinares em educação especial. Londrina: Editora UEL, 1998, p. 373-377. KUPFER, M. C. Freud e a educação: o mestre impossível. São Paulo: Scipione, 1997. 
71-82, 2001.

Duas notas sobre a inclusão escolar. Escritos da criança, Porto Alegre, n. 6, p.

MANTOAN, M. T. E. Ser ou estar, eis a questão: explicando o déficit intelectual. Rio de Janeiro: WVA, 1997.

Educação de qualidade para todos: formando professores para inclusão escolar.

Temas sobre desenvolvimento, v. 7, n. 40, p. 44-48, 2000.

MARCHESI, A.; ECHEITA, G.; MARTÍN, E. A avaliação da integração. In: PALACIOS, J.; COLL. C. ; MARCHESI, A. (Org.). Desenvolvimento psicológico e educação: necessidades educativas especiais e aprendizagem escolar. Porto Alegre: Artes Médicas, 1995 .

MARTINS, L. A. R. A inclusão escolar do portador da Síndrome de Down: o que pensam os educadores? Natal: EDUFRN, 2002.

MOLINA, S. E. A estruturação cognitiva na deficiência mental e, particularmente, na criança com Síndrome de Down: um enfoque a partir da interdisciplina e da transdisciplina. Escritos da criança, Porto Alegre, n. 6, p. 153-161, 2001.

SAMPAIO, S. Um ensaio sobre formação. Relatório final de estágio de pós-doutorado na Universidade de Paris 8. UFBA/CNPq. Salvador. 2002. Não publicado.

SAMPAIO, S. Um ensaio sobre formação. Salvador, 2002. Relatório final de estágio de pós-doutorado na Universidade de Paris 8. Não publicado.

TESSARO, N. S. Inclusão escolar: concepções de professores e alunos da educação regular e especial. São Paulo: Casa do Psicólogo, 2005.

VOLTOLINI, R. A inclusão é não toda. In: COLLI, F. A. G. (Org.). Travessias inclusão escolar: a experiência do grupo ponte Pré-escola Terapêutica Lugar de Vida. São Paulo: Casa do Psicólogo, 2005. p. 149-155.

VYGOTSKY, L. S. Fundamentos de defectologia. In: . Obras escogidas. Madrid: Visor, 1997. v. 5. 


\section{REFLEXÕES SOBRE A PRODUÇÃO SOCIAL DO CONHECIMENTO E AS CULTURAS INCLUSIVAS: o papel da avaliação}

Miguel Angel Garcia Bordas Fabio Zoboli

\section{INTRODUÇÃO}

O foco que nos orienta nesta comunicação é o tema da avaliação inclusiva. Como se constrói uma avaliação num contexto não classificatório? Como podemos entender a relação entre deficiência e as formas inclusivas do educar?

Achamos importante comentar e discutir esta dimensão a partir de um singelo documento que está aparecendo como Projeto Escola Viva - Garantindo o acesso e permanência de todos os alunos na escola: alunos com necessidades educacionais especiais. (BRASIL, 2000). É um documento de base que reúne estrategicamente tópicos que culminou com a realização de oficinas de debates entre profissionais da área jurídica, pedagógica e ligados a ONGs, dentre eles e que redigiram este oportuno manual.

O objetivo deste manual é divulgar os conceitos mais atuais com as diretrizes mundiais de inclusão de alunos com necessidades educacionais especiais.

Destacamos algumas pessoas que participaram na sua elaboração como: Antônio Sestaro; Advogado da Federação das Associações de Síndrome de Down; Elaine C. M. F. Perez, Pedagoga da Secretaria de Educação de Sorocaba; Elaine 
Cristina de Sá Proença, Procuradora da República; Eugênia Augusta Gonzaga Fávero, Procuradora da República; Lucinha Cortez, Assistente Social da Carpediem; Luisa de Marillac P. Pantoja, Promotora de Justiça do Distrito Federal; Maria Teresa Egler Mantoan, Professora da Faculdade de Educação da Unicamp.

O que nos interessa aqui, neste momento é apresentar alguns dos importantes aspectos das orientações pedagógicas que sinalizam "o direito a ser iguais quando a diferença nos inferioriza o direito a sermos diferentes, quando a igualdade nos descaracteriza" de acordo com o dizer de Santos (2002).

Para que as pessoas com deficiências possam exercer o direito à educação em sua plenitude, é indispensável que a escola de ensino regular se adapte às mais diversas situações e conforme as necessidades dos alunos inseridos em suas salas de aula.

$\mathrm{Na}$ perspectiva de uma educação inclusiva, não se espera mais que a pessoa com deficiência se integre por si mesma, mas que os ambientes, inclusive o educacional, se transformem para possibilitar essa inserção, ou seja, estejam devidamente preparados para receber a todas as pessoas, indistintamente.

Em se tratando de escola pública, o próprio Ministério da Educação tem um programa que possibilita o fornecimento de livros didáticos em Braille. Além disso, em todos os Estados estão sendo instalados centros de apoio educacional especializados e que devem atender às solicitações das escolas públicas. No caso de escolas particulares, da mesma forma, deve-se providenciar o material às suas expensas ou através de convênios com entidades assistenciais.

\section{A QUESTÃO DA AVALIAÇÃO DA APRENDIZAGEM COM ALUNOS DE EDUCAÇÃO ESPECIAL}

Assim, para que as escolas possam acolher a diversidade do alunado, reconhecendo e valorizando as diferentes capacidades, competências, habilidades que existem em uma sala de aula, elas precisam ser revistas inteiramente e mudar suas práticas usuais, marcadas pelo conservadorismo, excludentes e inadequadas para o alunado que já temos hoje nas escolas, em todos os seus níveis.

Este documento do Ministério da Educação intitulado Projeto Escola Viva reflete e promove atividades concretas permitindo tomar atitudes e ações afirmativas diante das dimensões complexas dos alunos com necessidades educacionais especiais (BRASIL, 2000). 
Pensamos que é importante repensar as práticas de avaliação de aprendizagem. Não podemos continuar pensando em instrumentos previamente e arbitrariamente estabelecidos pela escola. $\mathrm{O}$ aluno com necessidades educacionais especiais precisa ser acolhido com parâmetros flexíveis que lhe permitam atingir resultados de forma singular e particular. Assim deve ter oportunidade de atingir objetivos e poder mostrar desenvolvimento e mostrar que está apto ou não apto. Pensamos que as deficiências não podem ser medidas e definidas por si mesmas e mediante sistemas previamente padronizados por especialistas. Há que se levar em conta cada situação e estágio que resulta das formas de interação entre as características do aluno e dos ambientes em que está eventualmente inserido. É preciso ter acuidade e prestar atenção para que se possam estabelecer espaços de desenvolvimento adequados a atender as peculiaridades permanentes ou circunstanciais de cada aluno.

Chama a atenção muitas vezes o ambiente meramente classificatório das avaliações escolares que, de forma urgente, ficam auferindo com notas e provas, com uma pretensão apenas diagnóstica de algo que deve tentar ser um processo contínuo e qualitativo, visando depurar o ensino e torná-lo cada vez mais adequado e eficiente à aprendizagem de todos os alunos.

Essa medida já diminuiria substancialmente o número de alunos que são indevidamente avaliados e categorizados como deficientes, nas escolas regulares. A aprendizagem como o centro das atividades escolares e o sucesso dos alunos como a meta da escola, independentemente do nível de desempenho a que cada um seja capaz de chegar, são condições de base para que se caminhe na direção de escolas acolhedoras. O sentido desse acolhimento não é o da aceitação passiva das possibilidades de cada um, mas o de serem receptivas a todas as crianças, pois as escolas existem para formar as novas gerações, e não apenas alguns de seus futuros membros, os mais privilegiados.

Entendemos que os processos de aprendizagem e de inclusão de alunos com necessidades especiais não podem prever mecanicamente a utilização de métodos e técnicas de ensino específicas para esta ou aquela deficiência, por tabela Os alunos, cada aluno, aprendem até o limite em que conseguem chegar, se o ensino for de qualidade, isto é, se o professor considera o nível de possibilidades de desenvolvimento de cada um e tenta explorar essas possibilidades, por meio de atividades abertas, nas quais cada aluno pode engajar-se por si mesmo, na medida de seus interesses e necessidades, seja para construir uma ideia, ou resolver um problema, ou realizar uma tarefa. Eis aí um grande desafio a ser 
enfrentado pelas escolas regulares tradicionais, cujo paradigma é condutista, e baseado na transmissão dos conhecimentos.

A avaliação do desenvolvimento dos alunos também muda, para ser coerente com as outras inovações propostas. O processo ideal é aquele em que se acompanha o percurso de cada estudante, do ponto de vista da evolução de suas competências, para resolver problemas de toda ordem, mobilizando e aplicando conteúdos acadêmicos e outros meios que possam ser úteis para se chegar a soluções pretendidas; apreciam-se os seus progressos na organização dos estudos, no tratamento das informações e na participação na vida social da escola.

Não se pode imaginar uma educação para todos quando caímos na tentação de constituir grupos de alunos por séries, por níveis de desempenho escolar e determinamos para cada nível, objetivos e tarefas adaptados além de uma terminalidade específica. E, mais ainda, quando encaminhamos os que não cabem em nenhuma dessas determinações para classes e escolas especiais, argumentando que o ensino para todos não sofreria distorções de sentido em casos como esses!

Mesmo que o aluno não chegue a aprender exatamente tudo o que comumente os demais alunos aprendem, o que é provável - pois do contrário não haveria déficit intelectual algum - ainda assim tem o direito de ser avaliado por aquilo que conseguiu desenvolver e de chegar ao término do ensino fundamental, que é básico e obrigatório. No ensino médio, ele poderá além dos cursos tradicionais, optar por cursos profissionalizantes, cursos para jovens e adultos, que ainda retomem conteúdos de alfabetização, se necessário.

Poderíamos também refletir aqui sobre a questão e o sentido da seriação e dos ciclos educacionais a propósito da avaliação dos alunos portadores de necessidades especiais, vez que esta questão parece-nos da maior relevância. Neste ponto é preciso discutir também o pressuposto de que a estruturação de turmas escolares por séries podem ser homogeneizadas. Entendemos que organizações escolares por ciclos podem melhor favorecer e entender o funcionamento e acompanhar os processos de desenvolvimento e progresso dos alunos frente às dificuldades e situações-problema típicos dos processos de aprendizagem.

O texto desta cartilha, embora breve, introduz e apresenta dicas importantes para se ensinar a turma toda. Para ensinar a turma toda, parte-se da certeza de que as crianças sempre sabem alguma coisa, de que todo educando pode aprender, mas no tempo e do jeito que lhe são próprios. É fundamental que o professor nutra uma elevada expectativa pelo aluno. O sucesso da apren- 
dizagem está em explorar talentos, atualizar possibilidades, desenvolver predisposições naturais de cada aluno. As dificuldades, deficiências e limitações são reconhecidas, mas não devem conduzir/restringir o processo de ensino, como comumente acontece.

Para ensinar a turma toda, independentemente das diferenças de cada um dos alunos, temos de passar de um ensino transmissivo para uma pedagogia ativa, dialógica, interativa, que se contrapõe a toda e qualquer visão unidirecional, de transferência unitária, individualizada e hierárquica do saber.

Um dos pontos cruciais do ensinar a turma toda são a consideração da identidade sociocultural dos alunos e a valorização da capacidade de entendimento que cada um deles tem do mundo e de si mesmos. Nesse sentido, ensinar a turma toda reafirma a necessidade de se promover situações de aprendizagem que formem um "tecido colorido" de conhecimento, cujos fios expressam diferentes possibilidades de interpretação e de entendimento de um grupo de pessoas que atua cooperativamente. Sem estabelecer uma referência, sem buscar o consenso, mas investindo nas diferenças e na riqueza de um ambiente que confronta significados, desejos, experiências, o professor deve garantir a liberdade e a diversidade das opiniões dos alunos. Nesse sentido, ele deverá propiciar oportunidades para o aluno aprender a partir do que sabe e chegar até onde é capaz de progredir. Afinal, aprendemos quando resolvemos nossas dúvidas, superamos nossas incertezas e satisfazemos nossa curiosidade.

As diferenças entre grupos, étnicos, religiosos, de gênero etc. não devem se fundir em uma única identidade, mas ensejar um modo de interação entre eles, que destaque as peculiaridades de cada um. O professor, da mesma forma, não procurará eliminar as diferenças em favor de uma suposta igualdade do alunado, Antes, estará atento à singularidade das vozes que compõem a turma, promovendo o diálogo entre elas, contrapondo-as, complementando-as.

A perspectiva que se apresenta está alinhada aos conceitos do construtivismo na perspectiva vigotskiana de dimensões de co-construção conjunta de conhecimentos, ou seja, ensino expositivo x coautoria de conhecimentos.

O professor palestrante, tradicionalmente identificado com a lógica de distribuição do ensino, supõe que os alunos ouçam diariamente um discurso, nem sempre dos mais atraentes, em um palco distante, que separa o orador do público. 
O professor que ensina a turma toda não tem o falar, o copiar e o ditar como recursos didático-pedagógicos básicos. Ele partilha com seus alunos a construção/autoria dos conhecimentos produzidos em uma aula; trata-se de um profissional que reúne humildade com empenho e competência para ensinar.

O ensino expositivo foi banido da sua sala de aula, na qual todos interagem e constroem ativamente conceitos, valores, atitudes. Esse professor arranja e explora os espaços educacionais com seus alunos, buscando perceber o que cada um deles consegue apreender do que está sendo estudado e como procedem ao avançar nessa exploração.

Certamente um professor que engendra e participa da caminhada do saber com seus alunos e mediatizado pelo mundo, como nos ensinou Freire (1978), consegue entender melhor as dificuldades e as possibilidades de cada um e provocar a construção do conhecimento com maior adequação.

Os diferentes sentidos que os alunos atribuem a um dado objeto de estudo e as suas representações vão se expandindo, se relacionando e revelando, pouco a pouco, uma construção original de idéias que integra as contribuições de cada um, sempre bem-vindas, válidas e relevantes.

Escolas abertas às diferenças e capazes de ensinar a turma toda demandam, portanto, uma resignificação e uma reorganização completa dos processos de ensino e de aprendizagem. Não se pode encaixar um projeto novo em uma velha matriz de concepção do ensino escolar.

Nesse sentido, essas escolas contestam e não adotam o que é tradicionalmente utilizado para dar conta das diferenças nas escolas: as adaptações de currículos, a facilitação das atividades, além dos programas para reforçar as aprendizagens, ou mesmo para acelerá-las, em casos de defasagem idade/séries escolares.

Para melhorar a qualidade do ensino e para se conseguir trabalhar com as diferenças nas salas de aula é preciso que enfrentemos os desafios da inclusão escolar, sem fugir das causas do fracasso e da exclusão desconsiderando as soluções paliativas, sugeridas para esse fim. As medidas comumente indicadas para combater a exclusão não promovem mudanças e visam mais neutralizar os desequilíbrios criados pela heterogeneidade das turmas do que potencializá-los, até que se tornem insustentáveis, obrigando as escolas a buscar novos caminhos educacionais, que, de fato, atendam à pluralidade do coletivo escolar.

Resumindo podemos dizer que uma escola que reconhece e valoriza as diferenças presentes em suas salas de aula, tem que se preocupar em trabalhar 
com os conteúdos, de modo que possam ser aprendidos de acordo com a capacidade e ritmo de cada um.

Mas enquanto os professores do ensino escolar, especialmente os do nível fundamental, persistirem em práticas que não reconhecem e valorizam as diferenças na escola, não teremos condições de ensinar a turma toda.

Essas práticas poderiam sintetizar como hábitos docentes amplamente instalados, com os preconceitos construídos por valores emergentes de culturas avaliativas existentes, que caracterizando o ensino seriado, consistem em: propor trabalhos coletivos; ensinar com ênfase nos conteúdos programáticos, de forma escatologicamente ideal da série; adotar o livro didático, ou programas instrucionais, como ferramenta exclusiva de orientação dos programas de ensino seriado; servir-se da folha mimeografada ou xerocada para que todos os alunos as preencham ao mesmo tempo, respondendo às mesmas perguntas, com as mesmas respostas; propor projetos de trabalho totalmente ou parcialmente desvinculados das experiências e do interesse dos alunos, que só servem para demonstrar a pseudoadesão do professor às inovações; organizar de modo fragmentado o emprego do tempo do dia letivo para apresentar o conteúdo estanque desta ou daquela disciplina e outros expedientes de rotina das salas de aula; considerar a prova final, em cada momento de cada série, como decisiva na avaliação do rendimento escolar do aluno.

Essas práticas configuram o velho e conhecido ensino para alguns alunos, em alguns momentos, algumas disciplinas, atividades e situações de sala de aula e representam sérios obstáculos para uma mudança da cultura escolar que almejamos e estamos propondo em novo horizonte de promoção de espaços de desenvolvimento e novas vias reais de inclusão de pessoas com necessidades especiais.

A proposta educacional presente sugere uma aprendizagem, dentro de teorias que respeitem as mínimas condições de inclusividade e relevância com que os conteúdos possam ser trabalhados de forma significativa e motivadora (AUSUBEL, 1968; ROGERS, 1988).

É assim que a exclusão se alastra e se perpetua, atingindo a todos os alunos, não apenas os que apresentam uma dificuldade maior de aprender ou uma deficiência específica. Porque em cada sala de aula, sempre existem alunos que rejeitam propostas de trabalho escolar descontextualizadas, sem sentido e atrativos intelectuais, sempre existem os que protestam a seu modo, contra um ensino que não os desafia e não atende às suas motivações e interesses pessoais. 
O ensino para alguns é ideal para gerar indisciplina, competição, discriminação, preconceitos e para categorizar os bons e os maus alunos, por critérios que são, no geral, infundados.

O ensino para todos desafia o sistema educacional, a comunidade escolar e toda uma rede de pessoas, que se incluem, num movimento vivo e dinâmico de fazer uma Educação que assume o presente, como tempo que concretiza a mudança do alguns em todos, da discriminação e preconceito em reconhecimento e respeito às diferenças. É um ensino que coloca o aluno como foco de toda a ação educativa e possibilita a todos os envolvidos a descoberta continua de si e do outro, enchendo de significado o saber educar.

Outra questão muito importante, para finalizar esta preliminar reflexão são os recados que o manual passa para os pais de crianças com deficiência ou seus responsáveis, para os pais de crianças sem qualquer deficiência e para os professores.

O manual solicita dos primeiros coragem e prontidão para garantir-lhes e proporcionar-lhes o acesso à escola, ciente de suas responsabilidades nesse papel. Ele destaca ainda que deixar de mandar uma criança à escola pode significar sorrisos imediatos, mas, a longo prazo, as conseqüências podem ser danosas, além de orientar para que esses pais façam sua parte, de forma que esse processo de transição seja o menos longo possível. Pede aos segundos consciência da diversidade, a fim de possibilitar um preparo para a cidadania e um desenvolvimento humano muito maior para todos. E, finalmente, alertando aos professores sobre a necessidade de adotar incondicionalmente o lema da não exclusão, pois incluir, em primeiro lugar, é radicalmente deixar de excluir. Depois, o caminho é através da busca de informações e do exercício da cidadania através da cobrança dos instrumentos necessários que devem ser fornecidos pelos dirigentes e responsáveis pelas redes públicas e privada de ensino.

Destacamos, aqui, pois, neste breve artigo, esta atitude moral de responsabilidade que parte de uma aceitação de princípios éticos que devem ser universais pela sua dimensão humana e os valores sociais que representam dentro de uma coletividade que respeita a diversidade e as diferenças.

\section{REFERÊNCIAS}

ALVES, Rubem. A escola com que sempre sonhei sem pensar que pudesse existir. 3.ed. Campinas: Papirus, 2001.

AUSUBEL, David Paul. Educational psychology: a cognitive View. New York: Holt, Rinehart and Winston, 1968. 
BRASIL. Ministério da Educação. Secretaria de Educação Especial. Projeto Escola Viva Garantindo o acesso e permanência de todos os alunos na escola: alunos com necessidades educacionais especiais.Brasilia, 2000.

CARVALHO, Rosita Edler. A nova LDB e a educação especial. 2. ed. Rio de Janeiro: WVA, 1998.

FERRAZ JÚNIOR, Tércio Sampaio. Introdução ao estudo de direito: técnica, decisão dominação. 2. ed. São Paulo: Atlas, 1994.

FREIRE, Paulo. Cartas à Guiné-Bissau. Rio de Janeiro: Paz e Terra,1978.

MANTOAN, Maria Teresa Eglér. Todas as crianças são bem-vindas à escola! Campinas: Faculdade de Educação da Unicamp, 1997.

. Ensinando a turma toda: as diferenças na escola. Pátio: revista pedagógica, Porto Alegre, v. 5, n. 20, p.18-28, fev./abr. 2002.

OLIVEIRA, José Raimundo de; MANTOAN, Maria Teresa Egler (Org.). Mobilidade, comunicação e educação: desafios à acessibilidade. Rio de Janeiro: WVA, 1999.

ROGERS, Carl. Tornar-se pessoa. São Paulo: Martins Fontes, 1988.

SANTOS, Boaventura de Souza. Produzir para viver: os caminhos da produção não capitalista. Rio de Janeiro: Civilização Brasileira, 2002.

WERNECK, Cláudia. Sociedade inclusiva: quem cabe no seu todos? Rio de Janeiro: WVA, 1999. 1998.

. Ninguém mais vai ser bonzinho da sociedade inclusiva. Rio de Janeiro: WVA, 

PRÁTICAS PEDAGÓGICAS INCLUSIVAS 



\section{INCLUSÃO ESCOLAR EM FEIRA DE SANTANA: caracterização da prática pedagógica}

Gillianderson Freitas Ribeiro

Tânia de Souza Lima

Marilda Carneiro Santos

\section{INTRODUÇÃO}

O presente estudo decorre da pesquisa intitulada Educação Especial nas Escolas da Rede Municipal de Feira de Santana: identificação e caracterização do atendimento, desenvolvida pelo Grupo de Estudos e Pesquisas em Educação Especial (GEPEE), do qual fazemos parte na condição de bolsistas de Iniciação Científica pela Fundação de amparo à pesquisa do estado da Bahia (Fapesb) e graduandos da Universidade Estadual de Feira de Santana (UEFS).

Tal experiência tem nos permitido visualizar o atendimento dispensado aos estudantes com Necessidades Educativas Especiais (NEE) nas escolas da Rede Municipal situadas na zona urbana de Feira de Santana, especificamente, nas quatro primeiras séries do ensino fundamental, tornando possível uma maior aproximação com a realidade da educação inclusiva no nosso município.

A inclusão de alunos com NEE tem-se constituído numa aspiração compartilhada universalmente, embora a sociedade ainda se encontre em um processo de conscientização sobre os valores éticos e morais das relações humanas, no sentido de converter-se em uma organização social, efetivamente, inclusiva. Tal situação é preocupante, principalmente, no caso dos alunos com NEE, conforme pode ser evidenciado observando os dados publicados em 2000 pelo Mi- 
nistério da Educação e Cultura (MEC) os quais revelam que cerca de 6 milhões de pessoas em idade escolar tem alguma necessidade educativa especial e, dentre estas, apenas $5 \%$ recebem algum tipo de atenção educativa e/ou terapêutica. Trazendo a problemática para a realidade de Feira de Santana, pode-se perceber, em consulta ao Relatório do Centro de Apoio Pedagógico de Feira de Santana, da Diretoria Regional de Educação (DIREC/02), e consulta à Secretaria Municipal de Educação (Seduc) e ao Centro de Apoio Pedagógico (CAP), que 43 escolas estaduais e 30 escolas municipais têm acesso aos serviços de apoio pedagógico. Nesse contexto, o CAP atende a 191 alunos com NEE e, além disso, a Seduc informa que presta atendimento pedagógico e psicopedagógico a um contingente que se aproxima de 220 alunos, sendo estes, oriundos de 56 escolas do município.

Entretanto, é importante ressaltar que os funcionários das referidas instituições esclarecem que os dados, acima mencionados, são coletados mediante formulários encaminhados às escolas, porém, quando devolvidos, os mesmos voltam com informações equivocadas em virtude da confusão terminológica sobre o conceito de NEE. De modo que, tal expressão "remete ao docente a busca da resposta educativa que alguns educandos precisam em determinados momentos ou situações, não incluem só a alunos com déficit, motor ou intelectual." (LÓPEZ MACHIN, 2000, p. 24). Portanto, estas constatações reforçaram a relevância deste estudo, no sentido de conhecer a população com NEE e os serviços que a elas são oferecidos em Feira de Santana, com o objetivo final de contribuir para o aprimoramento dos serviços educativos já existentes dispensados aos referidos alunos.

\section{RECORRENDO À LITERATURA}

O tema educação inclusiva tem ocupado considerável espaço nos debates político-educacionais no Brasil e, neles, estão presentes as demandas educativas dos alunos, resultantes de características físicas, étnicas, culturais, socioeconômicas, etc. Tem-se constatado também a implementação de diversas políticas públicas no sentido de promover transformações no âmbito educacional e provocar mudanças no funcionamento dos sistemas de ensino e na qualidade do atendimento à diversidade presente no ambiente escolar.

Apesar da análise de vários estudiosos da temática contemplada nesta investigação, o aporte teórico, em sua essência, está baseado nos postulados da Escola Sócio-Histórico-Cultural representada por Vygotsky. De modo que, este, 
defende a ideia de que a educação deve ser centrada no potencial do aluno, onde o desenvolvimento psicológico seja olhado de maneira prospectiva, ou seja, para além do momento atual. O mesmo autor afirma, ainda, que não deve haver diferenças entre crianças, mesmo que a distinção entre elas vá se construir no modo como se desenvolve na interação com o seu entorno (VYGOTSKY, 1989).

Nos dias atuais, a sociedade brasileira, seguindo a tendência mundial, exige cada vez mais dos poderes públicos uma resposta afirmativa no tocante à educação das pessoas com necessidades educativas especiais, as quais requerem respeito, para conviver, produzir e atuar nesta sociedade, gozando dos mesmos direitos e deveres, independentemente das suas diferenças. Essa tendência encontra-se respaldada por documentos oficiais de âmbito nacional e internacional, fundamentando-se na Declaração Universal dos Direitos do Homem (ONU, 1948), na Declaração de Salamanca (1994), e no contexto brasileiro, na Constituição de 1988, especialmente, em seu artigo n. 208, e na Lei de Diretrizes e Bases da Educação Nacional (LDBEN), n. 9.394/96. As transformações empreendidas nestes documentos têm como justificativa a necessidade de alcançar a equidade, traduzida pela universalização do acesso de todos, à escola e a qualidade do Ensino.

Estes documentos merecem destaque, de forma específica, por versar sobre as recomendações relativas à busca por uma efetiva inclusão das pessoas com deficiência em todos os segmentos da sociedade. Desse modo, é importante que os profissionais que prestam apoio pedagógico a estas pessoas, conheçam tais documentos, pois o educador também desempenha um papel político fundamental para o desenvolvimento da cidadania. Ademais, estas leis são verdadeiros marcos históricos, cuja discussão no âmbito nacional e internacional tem sido bastante ampla e produtiva.

Nesse sentido, procura-se criar condições dentro da escola para que todos os alunos, com suas diferenças, possam se desenvolver e usufruir, com autonomia, do máximo de oportunidades de aprendizagem. Logo, as mudanças propostas para a escola, são as bases fundamentais do processo de inclusão educativa, constituindo-se, assim, como um imperativo moral, principalmente, numa sociedade tão excludente quanto à brasileira.

Com relação às diferenças, é válido considerar o que diz Mader (1997, p. 47) ao ressaltar que "um novo paradigma está nascendo, um paradigma que considera a diferença como algo inerente na relação entre os seres humanos." Assim, o estar junto no cotidiano vai promover a todos os sujeitos ativos no processo educativo a aprendizagem de valores e atitudes positivas que visam a 
aceitação, ao respeito e a valorização das diferenças e potencialidades de cada educando, tanto no âmbito escolar, quanto no familiar e social.

A partir disso, verifica-se que a formação docente e a prática educativa dos profissionais que atuam com alunos que apresentam algum tipo de deficiência (sensorial, motora, mental ou a associação de duas ou mais destas modalidades) são, sem dúvida, bases essenciais que sustentam a inclusão escolar. No entanto, essa formação só contribui de forma significativa quando associada às adaptações físicas, curriculares e atitudinais por parte das instituições de ensino, ou seja, promover não apenas uma integração física dos alunos com NEE no ambiente escolar, mas garantir a participação dos mesmos em atividades essenciais ao currículo do ensino regular. Esta ideia fundamenta-se na concepção de projeto político-pedagógico proposto pelo MEC

O projeto político-pedagógico é um instrumento técnico e político que orienta as atividades da escola, delineando a proposta educacional e a especificação da organização e os recursos a serem disponibilizados para sua implementação. Os princípios e objetivos de ordem filosófica, política e técnica permitem programar a ação educacional, imprimindo-lhe caráter, direção, sentido e integração, articulando-se com as seguintes dimensões da administração escolar: pedagógico-curricular, administrativa financeira, organizacional-operacional, comunitária, sistêmica e de convivência são os fundamentos que orientam a proposta educacional. (BRASIL, 2005, p.114).

Assim sendo, é imprescindível que as instituições de ensino que atuam com alunos com NEE adaptem-se fisicamente para a inserção dos mesmos e tenham seu quadro docente formado por profissionais aptos a trabalhar com os respectivos alunos, de modo que possam atender as diferenças individuais e o desenvolvimento de suas potencialidades, criando condições concretas de aprendizagem e capacitando-as para sua inserção ao mercado de trabalho.

Com base nessas discussões, conclui-se que a escola inclusiva precisa possuir um bom projeto pedagógico, diante do qual, toda a equipe escolar irá discutir tentar entender, promover transformações em sua organização e funcionamento, visando atender aos diversos tipos de necessidades. É fundamental também, que os professores desenvolvam o domínio teórico-prático sobre as concepções de ensino e aprendizagem, buscando sempre o aperfeiçoamento de sua prática, mediante observação sistemática dos avanços e necessidades/dificulda- 
des dos alunos. Então, faz-se mister que o professor seja um estudioso e um investigador dos resultados de sua atuação, a fim de aperfeiçoar sua prática. Sobre tal questão, Perrenoud (2000, p. 155) afirma que a competência mais importante dos docentes seja a de "[...] administrar a sua própria formação contínua, porque ela condiciona o desenvolvimento de todas as outras [...]." Neste sentido, a atitude e o estilo de ensino do docente representam fatores primordiais para assegurar o êxito de todos. Logo, uma nova abordagem educacional pressupõe pensar o ensino a partir de uma atitude aberta, flexível e, sobretudo, reflexiva em relação à própria prática educacional.

\section{A METODOLOGIA}

A pesquisa proposta é caracterizada como descritiva e fundamenta-se na abordagem qualitativa com aspectos quantitativos para melhor compreensão e visualização do objeto estudado. Para viabilização deste estudo e a obtenção dos dados foram realizadas observações in locus, entrevistas semiestruturadas, questionários, análise de documentos apresentados pela família à escola (relatórios mádicos) seccionada em três eixos temáticos. O primeiro eixo contempla questões relacionadas à caracterização do atendimento aos alunos com NEE, o segundo relacionado ao ambiente físico e aos recursos necessários a um atendimento que contemple a autonomia dos educandos e o terceiro eixo está relacionado às questões didático-pedagógicas. Busca-se mediante estes instrumentos captar informações que possibilitem a apreensão do fenômeno a ser estudado.

Também serão analisadas as mudanças implementadas nas práticas das escolas (gestão) e de sala de aula (metodologia de ensino) no que diz respeito à garantia de uma aprendizagem bem sucedida a todos os estudantes. Busca-se mediante estes instrumentos captar informações que possibilitem a apreensão do fenômeno a ser estudado, isto é, a inclusão escolar. Com relação ao atendimento pedagógico dispensado aos alunos com NEE na rede municipal de ensino de Feira de Santana, verifica-se que trata-se de um objeto ainda não explorado. Nesse sentido, o problema foco de nosso estudo é a necessidade urgente de conhecer a realidade da população dos alunos com NEE inseridos nas escolas municipais de Feira de Santana, a maneira como estão sendo incluídos e os recursos ou adaptações utilizadas no processo.

Os resultados serão apresentados através de relatório, sendo ilustrado com tabelas, gráficos, resumos, artigos e outras formas possíveis de divulgação científica. Pretende-se que a pesquisa possa servir como fonte de consulta e indica- 
dores sociais para possíveis implantações de políticas públicas municipais voltadas para a educação de alunos com NEE na cidade de Feira de Santana.

Os sujeitos selecionados para o estudo são os professores das 56 escolas do ensino fundamental ( $1^{\mathrm{a}}$ a $4^{\mathrm{a}}$ série) da rede pública municipal, da zona urbana do município de Feira de Santana, que tenham em sua sala de aula alunos com NEE. A população corresponde à totalidade de professores que correspondam a esta exigência.

\section{DADOS PARCIAIS DA PESQUISA}

Apesar de a pesquisa ainda estar em andamento, já é possível fazer algumas considerações sobre as revelações obtidas até o momento. Dessa forma, a observação e a coleta de dados demonstram que existe um alto percentual de professores (90\%) atuando com alunos com NEE sem uma preparação específica, tanto no que diz respeito à formação inicial, quanto à formação continuada para o atendimento a esse alunado. Verifica-se, ainda, que a precariedade no processo de formação repercute, de forma negativa, na construção da autonomia do educando, uma vez que o professor tende a primar pela homogeneidade, objetivando um aluno "ideal", e, nesta direção, prioriza as deficiências em detrimento das potencialidades, indo de encontro aos princípios inclusivistas.

Ainda neste âmbito, observou-se que as atividades desenvolvidas pelos professores, geralmente, não propiciam o desenvolvimento da autonomia, já que são atividades mecânicas e repetitivas, as quais não contribuem para o desenvolvimento de habilidades cognitivas e da emancipação do sujeito. Tal postura reflete a concepção reducionista com relação ao aluno com deficiência, sendo a mesma, influenciada pelo seu processo de formação, o qual, geralmente, não contempla a temática da educação inclusiva de forma satisfatória.

Observou-se também a inexistência de adaptação curricular, tanto no que se refere às adaptações significativas quanto às não-significativas. Neste contexto, as especificidades dos alunos não são levadas em consideração, aspecto que influencia diretamente no processo de ensino-aprendizagem, implicando dificuldades para os alunos e intensificando a exclusão dos mesmos no espaço escolar.

Além disso, pode-se perceber uma grande dificuldade relativa à comunicação e à acessibilidade dos alunos com NEE no ambiente escolar. No que se refere à comunicação, a dificuldade é mais visível na relação entre professor e aluno com deficiência auditiva ou visual. Fato que se deve à falta de intérpretes 
da Língua Brasileira de Sinais (Libras) de pessoas com domínio no sistema Braille para facilitar, assim, tal mediação. Esta condição provoca certo distanciamento entre os sujeitos envolvidos no processo de ensino-aprendizagem, visto que a linguagem é um fator essencial para o desenvolvimento do ser humano.

Com relação às barreiras arquitetônicas observou-se que as escolas visitadas não apresentam adaptações em sua estrutura física como rampas, alargamento de portas, banheiros adaptados etc., elementos que garantem a acessibilidade dos alunos que utilizam cadeiras de roda. Portanto, pertinente relembrar que a construção de uma escola inclusiva com vistas à formação da autonomia do educando exige a superação de barreiras arquitetônicas, psicossociais e pedagógicas.

\section{CONSIDERAÇÕES FINAIS}

A partir desses pressupostos, constatou-se que, na maioria das escolas da rede municipal de Feira de Santana, os docentes integram, mas não incluem os alunos com NEE em sua proposta pedagógica. Isto decorre da falta de um planejamento mais específico para orientar os processos de ensino-aprendizagem que tem lugar na sala de aula, de maneira que o professor consiga dar uma resposta à turma como um todo, além de atender às particularidades de cada aluno. Por esta razão, é fundamental reforçar que o planejamento seja construído de maneira flexível, a fim de atingir o máximo de interação e participação de todos nas atividades propostas.

Através desta pesquisa, pode-se constatar, ainda, que muitas das dificuldades vividas pelos alunos no processo de aprendizagem, derivam da maneira como o professor organiza suas atividades, da ausência de metodologias diferenciadas e de recursos didáticos específicos, além dos critérios e procedimentos de avaliação, os quais não respondem de modo satisfatório aos alunos com necessidades especiais. A esse respeito, vale ressaltar que, em 2004, a Unesco publicou o material voltado para a formação de professores denominado $M u$ dando as práticas de ensino: usando diferenciação curricular para responder a diversidade na sala de aula, cujo conteúdo, pode ser válido para contribuir com a prática docente já que o mesmo explicita como o professor pode diferenciar a apresentação, a maneira de promover as atividades e a avaliação do conteúdo curricular no sentido de ajudar todos os alunos a aprenderem e participarem mais ativamente em sala de aula. 
Em resposta a essas constatações, a presente pesquisa visa contribuir para o processo de melhoria da qualidade do ensino e da equidade da educação no município de Feira de Santana, através de dados relevantes com vistas à formação de um centro de documentação na área de educação especial. Tais dados podem constituir em fonte de consulta e indicadores sociais para a elaboração de políticas públicas e possíveis projetos de intervenção direcionados ao atendimento de alunos com NEE da rede pública de ensino.

\section{REFERÊNCIAS}

BRASIL. Lei n. 9.394, de 20 de dezembro de 1996. Estabelece as diretrizes e bases da educação nacional. Brasília, 1996. Disponível em: < http://www.planalto.gov.br/ ccivil_03/ Leis/ L9394.htm\#art92>. Acesso em: 15 set. 2007.

BRASIL, Ministério da Educação. Secretaria de Educação Especial. A educação especial e a educação superior. Brasília, DF, 2000.

BRASIL. Ministério da Educação. Secretaria de Educação Especial. Educar na diversidade: material de formação docente. Organização de Cynthia Duk. Brasília, 2005.

CARVALHO, R. E. Educação inclusiva: com os pingos nos “is”. Porto Alegre: Mediação, 2004.

DECLARAÇÃO de Salamanca. Sobre princípios, políticas e práticas na área das necessidades educativas especiais. 1994. Disponível em: < http://portal.mec.gov.br/ seesp/arquivos/pdf/salamanca.pdf>. Acesso em: 21 out. 2009.

LÓPEZ MACHÍN, R. Que es integracion escolar? In: CONGRESSO DE EDUCAÇÃO ESPECIAL. 1998, Habana. Anales... Habana, 1998.

MADER, G. Integração da pessoa portadora de deficiência: a vivência de um novo paradigma. In: MANTOAN, M. T. E. (Org.). A integração de pessoas com deficiência: contribuições para uma reflexão sobre o tema. São Paulo: Memnon, 1997.

PERRENOUD, P. 10 novas competências para ensinar. Porto Alegre: Artes Médicas, 2000 .

ONU. Declaração universal dos direitos humanos. Proclamada pela Assembléia Geral em 10 de dezembro de 1948. Disponível em: < http://www.camara.gov.br/cdh/

Tratados_e_Convencoes/declaracao_universal_dos_direitos_humanos.htm >. Acesso em: 10 set. 2007.

UNESCO. Mudando as práticas de ensino: usando diferenciação curricular para responder a diversidade na sala de aula. Paris, 2004.

VYGOTSKY, L. S. A. Fundamentos de defectología. In: Cinco. Ciudad de La Havana: Editorial Pueblo y Educación, 1989. . Obras Completas. Tomo 


\title{
MATERIAIS DIDÁTICOS ALTERNATIVOS PARA O ENSINO DE CIÊNCIAS A ALUNOS COM DEFICIÊNCIA VISUAL
}

\author{
Renata Barbosa Gonçalves \\ Carlos Alberto Fonseca Jardim Vianna \\ Sirley Brandão dos Santos
}

\section{INTRODUÇÃO}

A escola produz efeitos fundamentais no desenvolvimento cognitivo dos alunos, e ainda que ela assuma funções que antes eram de responsabilidade apenas da família e das comunidades locais e religiosas, a grande expectativa social, principalmente dos pais dos alunos, sobre essa instituição está relacionada à aprendizagem (SOARES, 2004). Neste contexto, um grande desafio surge para os profissionais da educação, que devem lutar para que todos os alunos tenham igual oportunidade de aprendizagem e de acessibilidade aos conhecimentos historicamente produzidos. Onde cada indivíduo necessita de suporte que o ajude a suprir suas deficiências e assim construir sua identidade para que possam exercer sua cidadania.

A sociedade vem ao longo de sua história passando por muitas mudanças de paradigmas em relação à educação. Os paradigmas na visão de Kuhn (2005), que foi o criador do conceito, são realizações científicas universalmente conhecidas que durante algum tempo fornecem problemas e soluções modelares para uma comunidade praticante de uma ciência. Quanto à educação inclusiva, ou seja, um processo que inclui pessoas portadoras de necessidades especiais ou de distúrbios de aprendizagem na rede comum de ensino em todos os seus graus 
(MRECH, 1998), o movimento começou a crescer a partir de 1990, em Jomtien, Tailândia, quando se realizou a Conferência Mundial sobre Educação para Todos. Ficou estabelecida pelas Nações Unidas que seria garantida a democratização da educação, que esta, independeria das diferenças particulares dos alunos.

No ano de 1994 no mês de junho, em Salamanca na Espanha, aconteceu a Conferência Mundial sobre Necessidades Educativas Especiais: acesso e qualidade, onde se reuniram representantes de diversos países e várias organizações internacionais com o objetivo de promover a educação para todos, analisando as mudanças fundamentais de políticas necessárias para favorecer o enfoque da educação integradora, capacitando realmente as escolas para atender todas as crianças, sobretudo as que têm necessidades especiais (DECLARAÇÃO ..., 1994).

A lei n. 9.394, de Diretrizes e Bases da Educação, promulgada no ano de 1996, no capítulo V que versa sobre a educação especial diz que entende-se por educação especial, para os efeitos desta lei, a modalidade de educação escolar, oferecida preferencialmente na rede regular de ensino para educandos portadores de necessidades especiais. A LDB prevê ainda, que quando necessário deve ser oferecido serviços de apoio específico na escola regular. Com este propósito foi criado em 1999 o Programa de Apoio a Pessoas com Necessidades Educativas Especiais (PAPNEE) no Centro Federal de Educação Tecnológica (Cefet), em Campos, visando oferecer suporte ao processo de ensino-aprendizagem de pessoas que buscam a educação profissional em seus diferentes níveis de ensino (básico, médio/técnico e tecnológico).

Neste artigo daremos ênfase: à importância do professor e da comunidade escolar na inclusão do aluno Portador de Necessidades Especiais (PNE); aos recursos didáticos necessários para facilitar o processo de ensino-aprendizagem de alunos com deficiência visual e a importância das aulas de reforço escolar para esses alunos matriculados no ensino médio regular do Cefet Campos, na área de Ciências (biologia, física, matemática e química).

\section{A CONTRIBUIÇÃO DA COMUNIDADE ESCOLAR PARA A INCLUSÃO}

O PAPNEE vem desenvolvendo no Cefet Campos, atividades de sensibilização e orientação dos professores que recebem alunos com necessidades especiais; de acompanhamento de alunos e abertura de espaço para questionamentos e sugestões na instituição; e de apoio ao aluno com deficiência 
visual através do Projeto de Apoio ao Aluno Portador de Deficiência Visual e do Projeto Inclusão Digital de Alunos com Deficiência Visual.

Atualmente a equipe do PAPNEE está formada por uma psicóloga, uma assistente social, uma professora de matemática, uma professora de física, um aluno e uma aluna bolsista de nível médio e três alunas bolsistas de nível superior desta instituição.

O aluno, quando chega à escola, não encontra só a sala de aula como espaço de aprendizagem, ele desenvolve a aprendizagem em todos os momentos nos quais encontra-se no espaço escolar. Quando a escola deixa clara sua proposta inclusiva, ela mobiliza a todos para que a inclusão aconteça com sucesso. Segundo Tiballi (2003) os princípios considerados orientadores para a escola inclusiva são: respeito às diferenças e igualdade de direitos; cooperação, tolerância e solidariedade; participação social e integração afetiva de todos, especialmente dos portadores de necessidades especiais; inclusão em oposição à exclusão no contexto escolar; em síntese, promoção da inclusão pela via da escola.

Espera-se que alunos e funcionários entendam de forma clara os objetivos da inclusão, pois participam como protagonistas do processo. O Cefet Campos através do PAPNEE reconhece que é um direito de cidadão garantir a oportunidade de aprendizagem a todos, com qualidade, sentindo-se com a responsabilidade de zelar pelo cumprimento dessas oportunidades, enquanto espaço público.

Os alunos com deficiência visual que ingressam no ensino médio do Cefet Campos passam pelo processo seletivo, momento em que são oferecidos recursos especiais para a realização das provas de acordo com as necessidades de cada um. Para que o candidato PNE seja aprovado precisa acertar no mínimo 30\% da prova, tendo dessa forma sua vaga garantida, independente de sua classificação.

Quando se fala no aluno com deficiência visual na sala de aula regular, surgem algumas questões como: o professor não se sente capacitado para orientar esse aluno; a presença desse aluno na sala durante as atividades pode atrapalhar o desenvolvimento dos conteúdos, para o aluno seria melhor estar numa classe especial onde receberia atendimento adequado. Essa idéia indica que a formação docente deveria discutir em seus currículos algumas estratégias que contemplassem a reflexão sobre os processos de inclusão que deveriam desde já, fazer parte da rotina da sociedade e principalmente do espaço escolar. 
Os professores devem cumprir o papel que funciona como agente organizador do currículo para o aluno, sempre atentos aos instrumentos educativos: textos, filmes e softwares, que podem ajudar a transmitir os conteúdos de maneira mais clara e efetiva para os alunos que apresentam um modo característico de aprendizagem Gardner (1995). Caso o professor se encontre em alguma situação na qual não saiba como agir, deve contar com o apoio da equipe especializada que deve ter em sua escola, prevista na LDB.

\section{OS RECURSOS DIDÁTICOS E OS MÉTODOS UTILIZADOS PELO PAPNEE NAS AULAS DE REFORÇO}

O PAPNEE dispõe no Cefet Campos, dos seguintes recursos: sala equipada com 4 microcomputadores, Programas DOSVOX, JAWS, Braille Fácil, impressora Braille Basic, Scanner, material didático em alto relevo, confeccionado com: película de PVC (cloreto de polivinila), massa de modelar, cola quente, lixa, isopor, tinta relevo, para dar suporte ao ensino das disciplinas: matemática, física, química, biologia, geografia e informática.

Dentre esses recursos didáticos utilizados no processo de ensino/aprendizagem desses alunos, os textos em Braille são uma alternativa no desenvolvimento de sua estrutura cognitiva. O sistema Braille de escrita consiste num código que utiliza combinações de pontos para representar as letras do alfabeto, os números, os símbolos matemáticos, físicos, químicos e os sinais de pontuação. Os pontos se imprimem no papel manualmente com um punção e reglete ${ }^{1}$ ou são datilografados numa máquina Perkins Braille ou ainda impressos por meio da impressora Braille. Os pontos em relevo são lidos pelos alunos com deficiência visual através do tato.

O PAPNEE disponibiliza para os alunos matriculados no Cefet Campos textos impressos em Braille. Os textos propostos pelos professores são digitados de forma específica pela equipe de bolsistas, quando são feitas as adaptações necessárias para facilitar a compreensão do aluno deficiente visual. As provas e avaliações realizadas pelos alunos com deficiência visual são as mesmas que as aplicadas a turma, e são impressas em Braille quando solicitadas pelos professores, que também podem optar por aplicá-las oralmente ou utilizando o programa DOSVOX.

\footnotetext{
${ }^{1}$ Instrumento usado para permitir que o indivíduo cego escreva.
} 
No caso específico de disciplinas que utilizam textos com muitas páginas utiliza-se um gravador para que o conteúdo seja disponibilizado aos alunos em fitas gravadas, pois uma folha impressa em tinta corresponde a aproximadamente três folhas em Braille.

O uso do computador através de programas como o DOSVOX e o JAWS permite aos alunos com deficiência visual o acesso a internet, digitação de textos que poderão ser impressos em tinta, consulta de textos, realização de provas. Este recurso possibilita ao professor a leitura dos textos produzidos por esses alunos, e ainda condições para que o aluno desenvolva atividades ligadas à pesquisa com autonomia.

O programa DOSVOX é um sistema que a auxilia o deficiente visual a fazer uso de microcomputadores da linha PC, através do uso de sintetizador de voz. O sistema realiza a comunicação oralmente com o deficiente visual em Português, sendo dispensável a utilização do mouse. O JAWS funciona oferecendo uma voz sintetizada em ambiente Windows, para acessar os softwares, aplicativos e recursos na internet, sendo dispensável o uso do mouse em ambos os programas.

O scanner instalado nos computadores do PAPNEE tem como objetivo acelerar a conversão de textos em tinta, para torná-los acessíveis aos alunos. Esse trabalho não consiste apenas em escanear os textos em tinta, pois a linguagem dos livros didáticos faz uso de recursos visuais, os textos escaneados passam por uma revisão, que tornam acessíveis aos alunos com deficiência visual.

A presença de figuras, tabelas e gráficos em textos escolares e não escolares é comum, pois estas representam uma forma de expressão de conhecimento científico e não científico. Essa linguagem visual, porém, acaba tornando-se inacessível a alunos com deficiência visual. Para minimizar essa falta de acessibilidade aos textos escolares o Projeto de Apoio ao Aluno com Deficiência Visual vem desenvolvendo materiais em alto relevo.

Para a construção desse material são utilizadas folhas de película de PVC, base de borracha, carretilha e punção. O punção ou a carretilha é que será responsável por "desenhar" na película de PVC. Por estar em cima de uma base de borracha, o punção ou a carretilha produzem o desenho em alto relevo. Para construir relevos são utilizados também: tinta relevo, massa plástica. Esse tipo de material também é utilizado para a construção de gráficos. $\mathrm{O}$ material em alto relevo vem com indicação de como a folha deve ser posicionada, para que o aluno tenha autonomia ao consultar o material. 
Os alunos com deficiência visual participam do processo de construção desse material, pois eles orientam quanto ao tamanho, forma e se o objetivo do desenho está sendo alcançado. Todo material em alto relevo constitui um recurso que o Projeto de Apoio ao Aluno Portador de Deficiência Visual disponibiliza para o desenvolvimento de um aprendizado efetivo, portanto esse recurso só cumpre o seu papel quando manipulado de forma que o profissional oriente os alunos com deficiência visual quanto ao que se espera que eles aprendam. Os recursos são disponibilizados para os alunos, não apenas nas aulas de reforço, mas também nas aulas regulares.

Outra experiência do Projeto de Apoio ao Aluno Portador de Deficiência Visual é a utilização de quadros imantados para as aulas de reforço da Química. Consiste na utilização de quadros metálicos e ímãs para que os alunos representem desenhos ligados aos conteúdos da disciplina. Com diferentes tamanhos de ímãs, o aluno representa ligações entre átomos. Essas representações são utilizadas para a Química Orgânica e Inorgânica. São fixados nos ímãs, identificação em Braille para representar os símbolos dos elementos químicos.

As cadeias carbônicas têm suas estruturas feitas em alto relevo na película de PVC, onde são colados os símbolos dos elementos químicos impressos em Braille. Para representação de geometria molecular foram construídos alguns modelos com isopor visando à percepção da variação nos ângulos de ligação entre os átomos, comprimento de ligação etc. Esses modelos com isopor também foram construídos para o aprendizado em História da Química, no que se refere à evolução dos modelos atômicos.

O PAPNEE oferece ainda aulas de reforço escolar na área de Biologia, com o desenvolvimento de material em alto relevo e tridimensional, construídos com isopor, gel, com tamanhos variados para representar as células. Em outros casos, também são confeccionados recursos em alto relevo na película de PVC. No estudo da Genética, por exemplo, são utilizados ímãs e a placa de metal, além dos textos em Braille.

\section{CONCLUSÃO}

Após a criação do PAPNEE, com o objetivo de construir estratégias para proporcionar aos alunos com necessidades educativas especiais, um ambiente escolar propício para aprendizagem, a cada início de ano letivo, orienta-se os professores que recebem esses alunos, quanto aos recursos disponibilizados pelo 
PAPNEE e ao modo de agir para minimizar as dificuldades que encontram em sala de aula.

Percebe-se no cotidiano escolar do Cefet Campos, um comprometimento dos professores e da comunidade escolar, no sentido de promover a inclusão desses alunos em diversos seguimentos da escola, tais como: espaço físico, equipamentos, aparelhos, utensílios e mobiliário. Tal sensibilização é bastante notável e as ações desenvolvidas pelo PAPNEE contribuem de forma efetiva na instituição, para que os alunos tenham iguais oportunidades de aprendizagem.

As aulas de reforço escolar e os recursos didáticos desenvolvidos pelo Projeto de Apoio ao Aluno Portador de Deficiência Visual desempenham importante papel na vida acadêmica desses alunos. Esse fato pode ser evidenciado no desempenho desses alunos, ao longo de suas avaliações, tendo rendimento em sua maioria, acima da média da escola que é a nota seis.

Portanto, o fato desses alunos precisarem realmente de classes especiais, pode ser palco de muitas discussões, considerando que quando lhe são oferecidas as mesmas condições para o aprendizado, demonstram muita capacidade para aquisição de novos conhecimentos e integração na sociedade onde estão inseridos.

\section{REFERÊNCIAS}

BORGES, J. A.; JENSEN, L. R. Cegos, computador, desenho. Revista Benjamin Constant, Rio de Janeiro, n. 22, p. 7-12, ago. 2002.

BRASIL. Lei n. 9.394, de 20 de dezembro de 1996. Estabelece as diretrizes e bases da educação nacional. Brasília, 1996. Disponível em: < http://www.planalto.gov.br/ ccivil_03/ Leis/ L9394.htm\#art92>. Acesso em: 15 set. 2007.

DECLARAÇÃO de Salamanca. Sobre princípios, políticas e práticas na área das necessidades educativas especiais. 1994. Disponível em: < http://portal.mec.gov.br/ seesp/arquivos/pdf/ salamanca.pdf $>$. Acesso em: 10 jul. 2006.

FREIRE, P. Pedagogia da indignação: cartas pedagógicas e outros escritos. São Paulo: UNESP. 2000.

GARDNER, H. Inteligências múltiplas: a teoria na prática. Tradução Maria Adriana Veríssimo Veronese. Porto Alegre: Artimed (reimpressão em 2000).

KUHN, T.S. A estrutura das revoluções científicas. Tradução Beatriz Vianna Boeira e Nelson Boeira. 9. ed. São Paulo: Editora Perspectiva, 260 p., 2005.

MRECH, L. M. (1998). O que é educação inclusiva? Integração, 10(20), 37-40. 
PROJETO DOSVOX. Versão 3.2. [2000?]. Disponível em: <http://intervox.nce.ufrj.br/ dosvox/ > . Acesso em: 10 jul. 2006.

SOARES, J. F. O efeito da escola no desempenho cognitivo de seus alunos. REICE, Revista Eletrônica Iberoamericana sobre Calidad, Eficácia y Cambio em Educación, v. 2, n. 2, 2004. Disponível em: < http://redalyc.uaemex >. Acesso em: 5 set. 2007.

TIBALLI, E. F. A. Estratégias de inclusão frente à diversidade social e cultural na escola. In: LISITA, V. M. S. de S.; SOUZA, L. F. E. C. P. (Org.). Políticas educacionais, práticas escolares e alternativas de inclusão escolar. Rio de janeiro: DP \& A, 2003. 


\section{EXCLUSÃO DAS CRIANÇAS CEGAS DA PRÁTICA DE ENSINO DA ALFABETIZAÇÃO ESPACIAL EM UM CONTEXTO DE ESCOLA INCLUSIVA}

Marcelo Torreão Sá

\section{INTRODUÇÃO}

A prática da alfabetização espacial tem sido a grande inovação do estudo da Geografia no que concerne ao processo do ensino dessa ciência para as séries iniciais. No entanto, falta uma maior abordagem dos teóricos a respeito desta prática e da relação deste com o debate atual da escola inclusiva. Com o paradigma da inclusão escolar, as discussões sobre as práticas de ensino ainda são muito pouco explorados, daí o ineditismo deste trabalho. O objetivo geral deste trabalho foi analisar criticamente as práticas da alfabetização espacial, proposta por teóricos da Geografia e áreas correlatas, e correlacionar com a questão da inclusão dos educandos com deficiência visual, na perspectiva do ensino-aprendizagem na diversidade.

O problema se centrou na seguinte questão: as práticas de ensino da alfabetização espaciais estão em consonância com os objetivos da inclusão escolar? E, ainda, como hipótese, tivemos a seguinte assertiva: a educação inclusiva traz em seu arcabouço uma modificação estrutural na prática docente, mas essa quebra de paradigma ainda não alcançou os teóricos que pensam e formulam as práticas de ensino.

A relevância social deste trabalho baseia-se no enfoque de uma melhor compreensão da inserção de pessoas com necessidades educativas especiais em 
uma sala regular, além dos transtornos destas pessoas no processo de aprendizagem, tendo em vista as práticas pouco específicos às suas necessidades. Portanto, esse trabalho aponta para a necessidade de reformulações teóricas nas práticas de ensino. Tem como prerrogativa uma nova perspectiva do ensino para todos. Por isso, este trabalho se justificou como de suma importância no processo de inclusão. Traz à tona novos pontos que poderão ser passíveis de estudo no trabalho dos profissionais empenhados no projeto de inclusão escolar.

As características delineadoras deste trabalho foram, conforme nos subsidia Lakatos e Marconi (1993), centradas nos direcionamentos a seguir.

A pesquisa seguiu alguns passos metodológicos. Partimos do trabalho monográfico Alfabetização espacial: por uma nova prática pedagógica para as séries iniciais do ensino fundamental (TORREÃO SÁ, 2004), que é utilizado aqui como dado secundário e serviu como revelação da prática de ensino dos docentes em relação à prática de ensino da alfabetização espacial.

No segundo momento, foram verificadas as propostas metodológicas sobre alfabetização espacial dos teóricos da área específica. Na etapa conclusiva, foram discutidas dialeticamente, através de análises, as condições gerais que alicerçam a alfabetização espacial e o projeto de inclusão escolar.

As fontes consultadas foram, basicamente, a monografia Alfabetização espacial: por uma nova prática pedagógica para as séries iniciais do ensino fundamental (TORREÃO SÁ, 2004) e livros de teóricos que discutem a alfabetização espacial.

\section{A PRÁTICA DE ENSINO DA ALFABETIZAÇÃO ESPACIAL}

A ciência Geografia trabalha com imagens e recorre a diferentes linguagens na busca de sustentação. Nesse sentido, ela utiliza uma linguagem peculiar (categorias e conceitos) e instrumentos específicos (mapas, cartas e plantas) que devem estar apoiados numa visão multidisciplinar de teorias e práticas que aparecem em movimento.

A observação, a descrição e a experimentação devem, portanto, ser ensinadas para que as crianças possam apreender a explicar, compreender e até mesmo representar os processos de reprodução do espaço geográfico. Isso não significa que estes procedimentos tenham um fim em si mesmos. Eles servem para construir noções, espacializar os fenômenos, levantar problemas e compreender propostas para conhecer e operar com os métodos e as explicações que a ciência geográfica produz. 
Nesta perspectiva, a ciência Geografia trabalha com a criança conforme vai se processando a sua percepção do mundo e evoluindo a socialização. No caso de crianças a serem alfabetizadas na ciência Geografia as questões como o reconhecimento de si mesmo(a) como sujeito no/do mundo são questões que a alfabetização espacial torna possível através de seus conceitos e práticas de ensino.

Mas afinal de contas o que significa alfabetização espacial? Segundo Catrogiovanni (2002, p.10) o termo designa "[...] a construção de noções básicas de localização, organização, representação e compreensão da estrutura do espaço $[\ldots .$.$] ", que se constitui em um processo fundamental para a descentração$ do aluno, na medida em que, facilita a sua leitura para além do mundo egocêntrico e, aperfeiçoa sua inteligência.

Tentando problematizar sobre o tema da alfabetização cartográfica ou espacial, Simielli (2005, p. 97) pontua que:

Em primeiro lugar, é preciso aproveitar-se do interesse natural da criança pelas imagens desde as séries iniciais [...]. Para atingir esse objetivo, devemos oferecer inúmeros recursos visuais, desenhos, fotos, maquetes, plantas, mapas, imagens de satélites, figuras, tabelas, jogos e representações feitas por crianças, acostumando o aluno à linguagem visual.

A proposta de Simielli (2005) é basicamente apresentar capacidades e habilidades que levem o aluno a compreender a linguagem cartográfica para que, a partir da $5^{\mathrm{a}}$ série ou $3^{\circ}$ ciclo, ele esteja apto para a compreensão dos fundamentos básicos da cartografia, podendo assim localizar e analisar, correlacionar e sintetizar, fenômenos descritos em cartas, mapas e planisfério.

Já Almeida e Passini (1989) abordam a questão da alfabetização espacial, apesar de não discutirem uma proposta específica para a introdução de uma prática de ensino da alfabetização espacial nas séries iniciais. As autoras se concentraram nos fundamentos de Piaget e Inhelder (1968) sobre a apreensão das noções espaciais, principalmente no capítulo quatro, onde abordam o comportamento das crianças no que diz respeito às várias etapas da alfabetização.

Esse livro foi de grande importância para esta pesquisa porque sugere a realização de atividades didáticas a serem executadas pelas crianças. As autoras, de forma elucidativa, descrevem passo a passo os procedimentos, materiais e interações interdisciplinares. Conforme as autoras, o objetivo principal da alfabetização espacial é o de possibilitar que o aluno se transforme de um simples 
leitor de mapas em um mapeador. "Em suma, através desta ação de mapear, e não através de cópias ou pinturas de mapas, dá-se um verdadeiro passo metodológico para o aprendizado de mapas." Ou seja, "[...], para que o aluno consiga dar significado aos significantes deve viver o papel de codificador, antes de ser decodificador" (ALMEIDA; PASSINI, 1989, p. 22).

Para Castrogiovanni (2002), o processo da alfabetização espacial está correlacionado com a apreensão do espaço pela criança e compreende três etapas nesta construção: o espaço vivido, o espaço percebido e o espaço concebido.

Inicialmente, a criança vive o espaço. A criança começa a primeira etapa da alfabetização espacial com o espaço vivido "é o espaço do "aqui", o espaço físico. A criança vivencia esse espaço a partir do movimento, da locomoção. Através do movimento, a criança começa a segunda etapa da alfabetização espacial. É a etapa de apreensão do espaço, ou seja, ele passa a ser percebido. A criança percebe o espaço sem ter que experimentá-lo biologicamente como espaço vivido. Começa a surgir o distanciamento da criança em relação ao espaço vivido. Para a Geografia, esse é um momento importante porque introduz a criança no mundo da leitura das paisagens. A partir do espaço percebido, a criança adentra na última etapa do processo de alfabetização espacial e está cada vez mais preparada para lidar com o espaço concebido. O espaço concebido é também o espaço abstrato. A criança passa do conhecimento espacial corporal para o formado pelos sentidos e, então, para um conhecimento espacial construído pela reflexão. Com a finalização do processo de alfabetização espacial, para Castrogiovanni (2002), a criança está apta a entender e compreender as abstrações cartográficas no terceiro ciclo do ensino fundamental.

\section{E O QUE É DEFICIÊNCIA VISUAL?}

A pergunta é facilmente respondida pelo senso comum como aquela pessoa que não enxerga; o indivíduo com uma visão sensitiva. Os médicos sempre tentaram responder pela ciência, analisar e levantar dados a respeito do que causava a deficiência, como as pessoas cegas utilizavam os outros sentidos, se a deficiência tinha cura e como poderiam ser aplainadas as dificuldades vividas pelos cegos. Os educadores, por seu lado, buscavam alternativas para executar a educação dos cegos. E, para isso, estudavam as limitações de inteligência e educabilidade. O fato é que a educação formal sempre utilizou práticas de ensino restritivas para a pessoa deficiente visual "quadro negro, atividades que requerem mobilidade, o processo de leitura e escrita. Os educadores, então, no 
processo histórico, desenvolveram outras formas de alcançar a independência global do indivíduo cego.

As restrições principais do deficiente visual são: a mobilidade, as atividades da vida diária, a educação visual, a compreensão da totalidade espacial e a simbologia social. Esses impedimentos requereram atitudes educativas específicas e, para tanto, foram criados métodos e técnicas específicas, que proporcionam possibilidades de superação dos obstáculos impostos pela deficiência visual. Foram então criados métodos e técnicas importantes para essas superações. A Atividade da Vida Diária (AVD), a Orientação e Mobilidade (OM) e o Sistema Braile de alfabetização de leitura e escrita são os principais auxiliares pedagógicos na educação dos deficientes visuais.

Para efeito de classificação, duas categorias principais de deficiência visual são estabelecidas: baixa visão e cegueira. A baixa visão é classificada quando o indivíduo tem a capacidade prejudicada por fatores que limitam a visão em alguns aspectos ou em vários. A criança parcialmente cega se educa através da visão. A cegueira se classifica como a perda total da capacidade de ver. A criança cega se educa através de práticas dos outros sentidos (tato, audição, paladar, sinestesia).

A prática é a culminância da teoria. É quando aplicamos os dados teóricos na tentativa de obtermos respostas dos educandos. Quando a prática não é bem elaborada, estruturada, ocorre a incongruência epistemológica, que cria lacunas na formação dos alunos com deficiência visual, chegando até a impossibilitá-los de progredir e entender novos assuntos que dependem de apreensão das estruturas pretéritas.

O processo de inclusão escolar do deficiente visual no ensino regular, nesta perspectiva, esbarra em algumas especificidades inerentes ao educando cego.

A alfabetização espacial requer da criança cega e do professor uma maior atenção e motivação para a aprendizagem formal das noções espaciais. O desenvolvimento da criança cega sofre interferência da perda visual, acarretando dificuldades para a compreensão e organização do meio. Observa-se a necessidade de estimulação permanente, dentro das possibilidades da faixa etária, a fim de que alcance progresso em todas suas potencialidades.

Nesse sentido emerge a questão: que prática de ensino deve-se utilizar para incluir um aluno deficiente visual numa classe normal? Que materiais utilizar, qual a frequência desta utilização e quais são as reações dos alunos frente à 
utilização desses materiais? São perguntas que os teóricos devem formular para adequar as atividades propostas para a alfabetização espacial com, crianças de cinco a 11 anos, deficientes visuais.

Exemplificaremos algumas atividades formuladas pelos teóricos Almeida e Passini (1989) e Castrogiovanni (2002) para efeito de entendimento da exclusão da prática de ensino da alfabetização espacial dos alunos com deficiência visual.

1. Cada bicho em sua casa: pedir para os alunos citarem os animais que eles conhecem. Depois dividir a turma em animais e casas. Uma casa para cada tipo de animal diferente. A casa será formada por dois alunos. Os animais são colocados fora da sala e as casas se misturam na sala, cada uma procura seu canto. A intenção é que cada animal que está fora entre na casa. Com isso, o professor poderá trabalhar com várias noções espaciais: vizinhança, ordem, fechamento, continuidade, direita, esquerda, de um lado, do outro, na frente, atrás etc.

2. Caça ao tesouro do pirata: o objetivo é (através de pistas) que os alunos descubram o tesouro enterrado pelo pirata. Dependendo da dificuldade das pistas, pode-se trabalhar várias noções espaciais. Por exemplo: saindo da sala, vá até o pátio e encontre o informante. Com a informação, ande até a cantina e peça um copo d'água. Observe e ache a lata azul localizada na cantina. Retire o envelope e leia a informação. E assim por diante, dificultando ou facilitando as pistas.

3. Mapeando o trajeto: percorra com as crianças algum trajeto na escola. Depois, ao voltar para a sala de aula, peça às crianças que descrevam alguns dos objetos referenciais por onde passaram. Desenhe em pequenos pedaços de papel várias vezes os objetos (a quantidade de dois desenhos iguais para cada aluno), depois peça que os alunos desenhem o trajeto colando os papéis desenhados na ordem de ida e depois de volta. Essa tarefa trabalha com noções topológicas e projetivas, assim como com questões de reversibilidade que são importantes para o entendimento do espaço concebido.

4. Lateralidade: em uma folha de oficio, no centro, localize a criança. Peça que a criança descreva, desenhando, quem está na frente dele, atrás, de um lado, do outro. O fundamental neste exercício é a questão da lateralidade e as relações projetivas.

Entende-se que neste trabalho, não caberia uma pormenorização e um alargamento explicativo destes exercícios. Achamos necessário apenas exemplificar as atividades, com o intuito de demonstração procedimental da alfabetização espacial, como um prática pedagógica em geográfica para as séries 
iniciais do ensino fundamental, e que em sua proposta não leva em conta a diversidade social, principalmente, a inclusão do deficiente visual.

\section{CONSIDERAÇÕES FINAIS}

Que importância tem conhecer e dominar as várias etapas da construção do espaço geográfico? Hoje em dia, encontramos adultos, professores, cidadãos comuns, analfabetos funcionais em termos espaciais. A característica desse analfabetismo é o desconhecimento com respeito às noções mais elementares de localização, organização e orientação no espaço geográfico.

Na própria formação dentro dos muros da academia, o docente é privado de reconhecer a alfabetização como um processo amplo, que envolve não somente o domínio dos códigos de leitura e escrita formais e numéricos, mas uma amplitude maior que englobe uma formação do educando globalmente, e não especificamente.

Gostando ou não, vivemos em um mundo que valoriza a funcionalidade e a eficiência, não importando os caminhos que adotamos para alcançá-las. A valorização das disciplinas como português e matemática reflete justamente isso. Não importa se você compreende o sentido das coisas, o que vale é executar tarefas. Se não compreendemos, por que adultos e crianças não têm noção de direita ou esquerda, profundidade, superfície, lateralidade? Se não compreendemos, por que a escola reforça os processos de alienação social? Não importa. Infelizmente, o que valida o conhecimento dos homens é o fato de eles saberem ler e escrever, mesmo que as qualidades da leitura e da escrita estejam essencialmente reduzidas a decodificar as letras do alfabeto e a fazer contas. Ler o mundo, se tornou uma tarefa acessória.

Neste trabalho, por outro lado, foi constatado o pouco interesse dos intelectuais em produzir material para subsidiar o ensino de geografia nas séries iniciais que leve em conta a inclusão escolar, principalmente na questão do deficiente visual, isso porque, historicamente a geografia escolar e os outros conhecimentos acadêmicos não estão dando importância à diversidade social. A inclusão e a educação especial tem sido vista como uma matéria de segunda categoria, quando são contempladas, mesmo nos cursos de licenciatura, ficam relegadas com uma carga horária pequena. Historicamente, também, as universidades contribuem para esse descrédito com relação à educação especial e a inclusão dos deficientes no sistema regular de ensino ao patrocinarem a forma- 
ção de professores como se estivessem formando técnicos, sem humanizá-los nem dar-lhes noção de ética, estética e cidadania participativa.

Felizmente, a partir do final da década de 1990, uma intensa mobilização dos educadores suscitou encontros específicos sobre a questão da inclusão escolar no ensino regular. A educação inclusiva instituída pela LDB n. 9.394/96 (BRASIL, 1996) criou um vazio funcional onde a mudança foi estabelecida, de cima para baixo, sem levar em conta as mudanças necessárias para a concretização do fato. Mittler (2003, p. 25) pontua: “[...] a inclusão envolve um processo de reforma e de reestruturação das escolas como um todo [...]. Isto inclui o currículo corrente, a avaliação, [...], a pedagogia e as praticas de sala de aula, [...].”

A grande questão levantada neste trabalho, que corrobora com a propositura citada acima, se baseou na produção intelectual sobre alfabetização espacial, teoria metodológica inovadora da ciência geográfica destinada ao ensino em educação infantil e das primeiras séries do ensino fundamental. Percebeu-se que os métodos de teóricos como Almeida e Passini (1989), Simielli (2005) e Castrogiovanni (2002), trabalham em uma perspectiva não inclusiva, pois em nenhum momento de seus trabalhos fazem menção teórica a técnicas e práticas de ensino destinadas a crianças deficientes.

O que desejamos é que, tomando como princípio à discussão sobre alfabetização espacial, o ensino inclusivo possa ser subsidiado por pensadores que levem em conta a compreensão de uma sociedade diversificada, em multidimensões e multicultural. E, que isso, reflita no processo de ensino-aprendizagem do educando, subsidiando a compreensão que o espaço é para ser compartilhado por indivíduos diferentes, pois só na diferença é que se constrói a igualdade.

Para esse fim temos que pensar em uma educação global inclusiva não só na estrutura ou no conhecimento, ou na própria escola, mas que tragam os intelectuais, que pensam e produzem conhecimento para a escola, a trabalhar pelo processo de inclusão escolar. Para que esses teóricos produzam métodos, técnicas e práticas que levem em conta a diversidade de indivíduos com suas limitações e potencialidades e não acabem jogando esses educandos para a margem do conhecimento, simplesmente por não poderem participar ou interagir com as atividades propostas.

Infelizmente, por culpa de um processo excludente e discriminatório, os signos trabalhados pelos professores tendem a parecer mortos para os alunos deficientes, porque são acadêmicos demais ou porque muitas vezes é incompreendido pelo próprio aluno. Por não fazerem parte do cotidiano deles, 
ou pelas limitações impostas pela deficiência, os alunos cegos, em sua maioria, ficam fora do conhecimento produzido/reproduzido em sala de aula.

Existe ainda pouca aproximação da escola com a vida. A escola não se manifesta atraente frente ao mundo contemporâneo, pois não dá conta de explicar e contextualizar as novas leituras da vida. A vida fora da escola é cheia de mistérios, emoções, desejos e fantasias, mas dentro dos muros escolares tudo soa desinteressante, o que torna urgente a teorização da vida. A vida precisa ser teorizada pelo professor para que os alunos possam compreendê-la e representála melhor.

Torna-se de fundamental importância nesse sentido, abrirmo-nos para aceitar a diversidade. Os valores dos educadores e intelectuais que pensam e formulam as práticas de ensino a serem aplicados em sala de aula, nem sempre são os mesmos dos alunos, por isso mesmo, aos educadores e intelectuais cabe perseguir as constantes e instigadoras (re)leituras e (re)interpretações dos nossos códigos morais, culturais e sociais, sem desprezar aqueles que foram adotados pela sociedade. "É necessário repensar o significado da prática pedagógica, a fim de tentar evitar os erros do passado quando os alunos deficientes eram deixados a margem." (FERREIRA; GUIMARÃES 2003, p. 44). Os autores pontuam ainda que:

A história das tentativas de mudanças pedagógicas tem centrado a inovação educacional na reforma de métodos, técnicas e programas deixando intocadas as práticas, a estrutura de instituições, as relações escolares, as posturas profissionais, os tempos e espaços onde se processa a educação do aluno e, ainda, os rituais que dão concretude aos conteúdos intelectuais e formativos (FERREIRA; GUIMARÂES, 2003, p. 16).

Em síntese, nos primeiros anos da escolarização, devemos trabalhar com a idéia de inclusão, compreendendo aí a valorização da diferença. Não se deve, portanto, limitar o ensino à análise do que está próximo de nós, mas sempre que possível é imprescindível lidar com a diversidade social e com os movimentos amplos e inovadores.

E para tal feito a universidade, como centro de pesquisa, ensino e extensão, deve valorizar o novo e incentivar pesquisas que tenha o intuito de contribuir para a construção de um ensino de qualidade e inclusivo para todas as nossas crianças. 
Não trata-se aqui, portanto, de forjar uma afinidade com a prática de ensino da alfabetização espacial, pura e simplesmente, e criticar seus criadores e inovadores, mas sim, trata-se de enxergar uma mudança de mentalidade que busque a diversidade e a inclusão escolar, em sua inteireza e em todos os níveis de produção da educação nacional. Tendo como perspectiva que a alfabetização espacial pode se transformar em uma prática de ensino fundamental para a trilha que a criança deficiente visual vai fazer na escola.

\section{REFERÊNCIAS}

ALMEIDA, R. D. de; PASSINI, E. Y. O espaço geográfico: ensino e representação. São Paulo: Contexto, 1989.

BRASIL. Lei n. 9.394, de 20 de dezembro de 1996. Estabelece as diretrizes e bases da educação nacional. Brasília, 1996. Disponível em: < http://www.planalto.gov.br/ ccivil_03/ Leis/ L9394.htm\#art92>. Acesso em: 15 set. 2007.

CASTROGIOVANI, A. C. Ensino de Geografia: práticas e textualizações no cotidiano. Porto Alegre: Mediação, 2002.

FERREIRA, M. E. C.; GUIMARÃES, M. Educação inclusiva. Rio de Janeiro: DP\&A, 2003.

FREIRE, P. A importância do ato de ler: em três artigos que se completam. São Paulo: Cortez, 1995.

LAKATOS, E. M.; MARCONI, M. de A. Fundamentos de metodologia cientifica. São Paulo: Atlas, 1993.

MITTLER, P. J. Educação inclusiva: contextos sociais. Porto Alegre: Artmed, 2003.

PIAGET, J.; INHELDER, B. A psicologia da criança. Tradução de Octavio M. Cajado. São Paulo: Difel, 1968.

SANTOS, Milton. Por uma outra globalização: do pensamento único à consciência universal. Rio de Janeiro: Record, 2005.

SIMIELLI, M. E. R. Cartografia no ensino fundamental e médio. In: CARLOS, A. F. A. (Org.). A geografia na sala de aula. 2. ed. São Paulo: Contexto, 2005, p. 92-108.

TORREÃO SÁ, M. Alfabetização espacial: por uma nova prática pedagógica para as séries iniciais do ensino fundamental. 2004. 65f. Monografia (Graduação em Pedagogia) Universidade Estadual do Sudoeste da Bahia, Jequié, 2004. 


\section{CONSCIÊNCIA FONOLÓGICA E SISTEMA BRAILLE: \\ reflexões sobre o tratamento da ortografia}

Iara Rosa Farias

Amanda Ribeiro Botelho

\section{INTRODUÇÃO}

Após algum tempo de trabalho com uma criança cega, já alfabetizada e com nove anos de idade, percebemos suas dificuldades com a escrita, pois suas atividades apresentavam frequentes "erros" ortográficos - jogol (jogou), conseguio (conseguiu), dici (disse), procurarão (quando na verdade queria dizer procuraram - verbo no passado). Embora esses "erros" ortográficos sejam comuns nessa fase, precisam ser corrigidos, pois a escrita é uma convenção que permite a comunicação entre as pessoas e tem grande peso social.

Com o objetivo de auxiliar a criança em questão na aquisição da ortografia oficial, buscamos referências de como tratar os "erros" ortográficos presentes na escrita das crianças cegas, porém, não encontramos materiais que abordassem esse assunto. Dessa forma, iniciamos um estudo exploratório sobre o trabalho de consciência fonológica voltado para essas crianças. Esse trabalho tratará apenas de pessoas com deficiência visual que apresentam cegueira e utilizem o sistema Braille. A baixa visão não será abordada nesse artigo.

Antes de adentrar no assunto propriamente dito, se faz necessário apresentar uma definição que pode ser tomada como pedra fundamental do nosso trabalho: o que se entende por deficiência visual. Vejamos. 
A deficiência visual, segundo Caiado,

[...] é uma categoria que inclui pessoas cegas e pessoas com visão reduzida. Na definição pedagógica, a pessoa é cega, mesmo possuindo visão subnormal, quando necessita de instrução em braile; a pessoa com visão subnormal pode ler tipos impressos ampliados ou com auxílio de potentes recursos ópticos. (INSTITUTO BENJAMIN CONSTANT, 2002).

Continuando...

A definição clínica afirma como cego o indivíduo que apresenta acuidade visual menor que 0,1 com a melhor correção ou campo visual abaixo de 20 graus; como visão reduzida quem possui acuidade visual de 6/60 e 18/60 (escala métrica) e/ ou um campo visual entre 20 e 50 graus, e sua visão não pode ser corrigida por tratamento clínico ou cirúrgico nem com óculos convencionais. (CARVALHO, 1994 apud CAIADO, 2003, p. 33).

É importante compreender minimamente o que se entende por deficiência visual, pois, em nossa sociedade, na aquisição da escrita, o principal órgão utilizado é a visão e podemos perceber isso através da história da escrita.

Desde a Pré-História, o homem se comunicava através de desenhos feitos nas paredes das cavernas. Na antiga Mesopotâmia, os sumérios desenvolveram a escrita cuneiforme, cunhada em placas de barro. Os egípcios desenvolveram a escrita hieroglífica, formada por desenhos e símbolos. Para esses sistemas de escrita a visão era um importante instrumento utilizado para sua aquisição e podemos dizer que nos tempos atuais continua sendo relevante ou que é o principal órgão utilizado. Nossa escrita, seja em que suporte for - cartazes, folhas de livros, monitores de computador etc. - necessita do órgão da visão para ser apreendida e, pois, compreendida e interpretada.

As pessoas cegas não podem ser alfabetizadas utilizando-se da visão. Para que a alfabetização ocorra satisfatoriamente é preciso recorrer a outro suporte de escrita com regras próprias. Enfim, foi a partir disso que chegou-se a criação de um sistema pelo qual pessoas cegas pudessem ler e escrever. Diante deste contexto se constituiu o sistema Braille. ${ }^{1}$ Ele permite aos cegos se alfabetizarem

\footnotetext{
${ }^{1}$ O Sistema Braille é um método universal de leitura e escrita para cegos e foi criado em 1824, por Louis Braille, que ficou cego aos 5 anos de idade. A cela Braille básica é composta por duas colunas verticais,
} 
e consequentemente a estabelecerem a comunicação pela "escrita" e, dessa maneira, ter também acesso aos conhecimentos e bens culturais já transcritos para o sistema.

Diz-se sistema porque o braille possui regras próprias de escrita. Da mesma forma que a escrita à tinta possui suas regras e convenções, o Braille também as possui, embora haja muitas correlações entre os dois sistemas de escrita (à tinta e o Braille). Por isso, é fácil inferir que da mesma forma que ocorrem "erros" na ortografia e usos da escrita à tinta, isso pode ocorrer também na escrita Braille.

Muitos professores, para "trabalhar" a ortografia com as crianças que têm a visão dita normal utilizam, principalmente, instrumentos que têm por suporte a visão, como gravuras, jogos de memória, cartazes, panfletos, rótulos entre outros, e buscam adaptar essas atividades para crianças cegas. No entanto, nem sempre tais adaptações proporcionam uma aprendizagem satisfatória. É preciso entender que o professor de uma criança, e até mesmo adulto, não-vidente está diante de uma situação especial.

Então, como tratar os "erros" ortográficos presentes nas escritas dos nãovidentes que utilizam o sistema Braille? Antes de responder a questão vamos falar um pouco sobre a ortografia e qual a sua função.

\section{A IMPORTÂNCIA DA ORTOGRAFIA}

Mas por que, diante de tantas demandas sociais, políticas e humanitárias de uma pessoa com necessidade educacional especial, tratar de questão que parece, à primeira vista, tão secundária, para não dizer supérflua?

Para respondermos tal questão traremos para arena da nossa argumentação as palavras de Cagliari (1997, p. 28):

O objetivo mais geral do ensino de português para todas as séries da escola é mostrar como funciona a linguagem humana e, de modo particular, o português; quais os usos que tem, e como os alunos devem fazer para estenderem ao máximo, ou abrangendo metas específicas, esses usos nas suas modalidades escrita e oral, em diferentes situações de vida.

com três pontos cada uma, totalizando 6 pontos. Na primeira coluna encontramos os pontos 1,2 e 3 e na segunda coluna encontramos 4,5 e 6 . Com esta cela é possível formar 64 combinações que representam letras, pontuação, números, sinais matemáticos etc. (ALEGRE, 2006). 
Além disso, outra razão igualmente relevante é que boa parte dos bens culturais da humanidade se encontra guardado pela escrita. Tendo isso claro, podemos dizer que a escrita tanto é um meio de armazenamento de conhecimentos produzidos pelas sociedades e diferentes culturas, como também pode ser um meio de ocultação desses mesmos conhecimentos. Dessa forma, se ater às questões imanentes da escrita, suas regras e convenções, por exemplo, é uma forma de oferecer ao aluno mais uma forma de se expressar e de ser entendido e, como já dito, ter acesso aos bens culturais armazenados que se utilizaram da escrita. Além disso, a escrita tem grande peso na nossa sociedade e assim se faz necessário escrever segundo a convenção ortográfica oficial.

O professor que trabalha especificamente com a língua portuguesa (educação infantil e ensino fundamental) precisa deixar claro para seus alunos e, inclusive deve ter claro para si, o objetivo mais geral do ensino das regras gramaticais e ortográficas da linguagem escrita. Ao se ater a tais questões se faz necessário observar que as pessoas já falam português, desde muito cedo, e que as crianças analisam a fala, com muita competência e as suas escritas refletem a percepção que têm da fala. Além disso, é preciso considerar as variedades linguísticas na modalidade oral. Enfim, antes de se ater às regras ortográficas, é necessário refletir sobre as características e particularidades da língua portuguesa e respeitar o saber constituído dos alunos.

Ao ver, por exemplo, uma criança escrever "disi" (disse) o professor não deve considerar um erro absurdo. Pelo contrário, a criança mostra que analisou a fala antes de escrever, ou seja,

está transpondo para o domínio da escrita algo que reflete sua percepção da fala. Isto é, a criança escreveu a palavra não segundo sua forma ortográfica, mas segundo o modo como ela pronuncia. Em outras palavras, fez uma transcrição fonética. (CAGLIARI, 1997, p. 30).

A escola e os professores precisam ter cuidado para que seus alunos não percam essa capacidade, ao tomar como base para tudo, a escrita ortográfica. (CAGLIARI, 1997)

O que fazer então? Os professores devem mostrar aos alunos a função da ortografia, e não simplesmente considerar erradas as escritas fora desse padrão. É preciso explicar o grau de importância da ortografia na sociedade. Interessante observar que somente as preocupações com normas não bastam para uma 
comunicação efetiva, pois muitos alunos escrevem textos ortográfica e gramaticalmente corretos, porém suas ideias não se apresentam de maneira clara.

Para explicar o papel da ortografia, o professor precisa demonstrar às crianças que cada uma delas fala de uma maneira diferente e, se cada uma fosse escrever como costuma falar, haveria muitas possibilidades de escrita, ocasionando uma grande confusão quanto à forma de grafar, dificultando, consequentemente, a leitura. É por essa razão que existe a ortografia que corresponde à Norma Padrão, assim

[...] para facilitar a leitura, a sociedade achou por bem decidir em favor de um modo ortográfico de escrever as palavras, independente dos modos de falar dos dialetos, mas que pudesse ser lido por todos os falantes, cada qual ao modo de seu dialeto. (CAGLIARI, 1997, p 32).

Os "erros" ortográficos presentes na escrita das crianças com visão normal também são encontrados na escrita da criança cega. Porém, esses erros podem ser ainda mais presentes na escrita Braille, pois não é um sistema amplamente compartilhado, como a escrita à tinta, fazendo com que o cego só tenha contato com a escrita no período de escolarização. Como afirma Almeida (2005), professora do Instituto Benjamin Constant,

de maneira inversa a da criança vidente que incorpora, assistematicamente, hábitos de escrita e de leitura desde muito cedo, a da criança cega demora muito tempo a entrar no universo do 'ler e escrever'. O sistema braille não faz parte do dia-adia, como um objeto socialmente estabelecido. Somente os cegos se utilizam dele. As descobertas das propriedades e funções da escrita tornam-se impraticáveis para ela. As crianças cegas só tomam contato com a escrita e com a leitura no período escolar. Esse impedimento, sabe-se, pode trazer prejuízos e atrasos no processo de alfabetização.

As crianças videntes começam a tomar consciência da língua escrita muito cedo, antes mesmo de iniciar o processo de alfabetização. Elas podem ver os pais lendo jornal, podem ver os símbolos escritos, enquanto passeiam, quando brincam, quando assistem televisão e descobrem desde cedo que as letras existem. As crianças cegas não têm essa possibilidade de contato com a escrita e para que tomem consciência de sua existência dependem de alguém para colar 
etiquetas em Braille nos objetos em sua casa, com seus respectivos nomes. É através disso que a criança perceberá que o Braille existe e pode ser usado para escrever o nome dos objetos (HORTON, 2006).

Como já dissemos há pouco, a escrita à tinta é um sistema com suporte visual e, portanto, o principal instrumento utilizado por ela é a visão. Embora o sistema Braille seja constituído de modo que os cegos tenham a possibilidade de escrever, de ler e de se comunicar, tais pessoas ainda não têm as mesmas oportunidades de tomada de consciência da existência de uma língua escrita desde cedo. Essa desvantagem pode ser um dos fatores que ocasionam maior incidência de "erros" ortográficos. Além disso, a pouca intimidade, isto é, o pouco contato com a leitura pode ser uma das causas das escritas das crianças (cegas ou com visão normal) não apresentarem a ortografia segundo as regras da Norma Padrão.

Devido à falta de recursos da maioria das escolas, as bibliotecas não possuem em seus acervos livros em Braille, já que estes têm um elevado custo de produção. Nesse sentido, a gravação de livros, a leitura dos livros por um adulto e os sintetizadores de voz ampliam as oportunidades de realização da leitura dos materiais impressos que não foram transcritos para Braille. Contudo, essas soluções de acesso ao conhecimento apresentam uma grande desvantagem: não permitem que a criança faça a leitura sozinha, não oferecendo o acesso à língua escrita da mesma maneira que o Braille oferece. Esse é um quesito fundamental para a diminuição de "erros" ortográficos na produção escrita. Enfim, o livro em Braille é o melhor meio de apresentar as regras ortográficas para a pessoa cega, por estar em um formato que permite o contato direto com a ortografia das palavras.

No entanto, um texto em Braille ocupa muito espaço. Livros com mais de cem páginas podem chegar a quinhentas páginas quando transcritos para esse sistema. Isso dificulta o transporte dos livros por serem mais pesados. Além disso, é preciso pessoas capacitadas para realizar a transcrição dos materiais para o Braille. A impressora ainda é muito cara e pouquíssimas instituições têm esse equipamento, não sendo possível atender à toda população de deficientes visuais. Quando o material é transcrito manualmente leva-se mais tempo para que a adaptação do material seja concluída e, muitas vezes, os transcritores não recebem com antecedência o material que precisa ser adaptado. Dessa forma, as crianças cegas têm dificuldades para ter acesso aos livros em Braille no decorrer da educação básica, do ensino superior, em cursos de línguas, em aulas de música etc. No entanto, mesmo diante deste quadro é relevante que os não-viden- 
tes dominem a ortografia oficial. Para que isso seja possível apresentaremos a proposição do trabalho de consciência fonológica voltado para crianças cegas.

\section{CONSCIÊNCIA FONOLÓGICA COMO FORMA DE AUXILIAR AQUISIÇÃO DAS REGRAS ORTOGRÁFICAS}

Já que as regras ortográficas são necessárias para que haja comunicação, é preciso solucionar os "erros" de ortografia presentes na escrita do deficiente visual. Referências ainda não foram encontradas sobre como tratar os "erros" de ortografia das crianças cegas. No entanto, as pesquisas de Capovilla e Capovilla (2000), Cárnio e Santos (2005), Barrera e Maluf (2003), Cardoso-Martins (1999) constataram a importância da consciência fonológica para a aquisição das regras ortográficas, em crianças videntes, inclusive com Síndrome de Down. A partir disso, levantamos a seguinte hipótese: atividades que contribuam para o desenvolvimento da consciência fonológica podem favorecer também a diminuição dos erros ortográficos nas produções escritas das crianças cegas.

Entende-se por Consciência Fonológica (CF) a habilidade metalinguística de tomada de consciência das características formais da linguagem. Noutros termos, consciência fonológica é entender que a linguagem oral está organizada e segmentada: em frases, palavras, sílabas e fonemas e que estes fragmentos se repetem e formam palavras e frases. Esta mesma organização está presente na linguagem escrita com mais um fator agregado: a relação entre som e letra. A CF pode, por esta razão, ser divididas em sub-habilidades de acordo com a capacidade para perceber características e particularidades da linguagem como: a) rimas e aliterações; b) frases (organização e segmentação); c) palavras; d) sílabas e; e) fonemas (NASCIMENTO, 2004).

Os resultados da pesquisa de Barrera e Maluf (2003) mostraram uma correlação positiva, bastante significativa, entre os níveis de CF e de aquisição da linguagem escrita, sobretudo no que se refere às crianças de cinco e seis anos. A pesquisa de Capovilla e Capovilla (2000) verificou os efeitos do trabalho com exercícios de $\mathrm{CF}$ em crianças com baixo nível socioeconômico e constatou que elas apresentaram melhor desempenho na escrita. Na pesquisa de Cárnio e Santos (2005) foi constatado que através de um programa de estimulação fonoaudiológica, crianças do ensino público fundamental apresentaram evolução de CF. O estudo realizado por Cardoso-Martins (1999) investigou a relação entre a CF e a habilidade de leitura na Síndrome de Down e observou influências positivas do desenvolvimento dessa consciência para a aquisição da escrita. 
Podemos dizer, então, que o trabalho envolvendo exercícios para o desenvolvimento de consciência fonológica tem resultados satisfatórios. Dessa forma, buscamos desenvolver uma investigação de como exercícios de CF podem ser dirigidos às crianças, primeiramente, cegas para posteriormente estender o trabalho para adolescentes e adultos. Nossa hipótese, como já apontado no começo deste trabalho, é que se a criança fizer exercícios de CF, na escrita Braille, vai apreender muitas regras de ortografia da língua portuguesa. É claro que os exercícios sozinhos não resolvem os problemas de ortografia. É preciso que a criança leia livros e outros materiais em Braille, sempre que possível. Porém, exercícios com rimas e aliterações podem auxiliar a criança não-vidente a reconhecer, na escrita, as partes das palavras que repetem a mesma forma ortográfica (O rato disse para o gato: - Posso fazer seu retrato?) e até mesmo observar que sons iguais se escrevem de formas diferentes (MEL e CÉU, por exemplo).

Outra questão que pode ser resolvida com o trabalho de CF, utilizando o sistema Braille, é evitar a aglutinação de palavras. Isto é, ao se trabalhar com a "leitura" de frases de forma sistematizada e pausada, a criança cega vai observar que as palavras da frase são separadas. Para isso seria proposto formar frases a partir de fichas em Braille de modo que a criança manipule as palavras escritas de forma convencional. Aqui poderia entrar como coadjuvante as manchetes de jornais e revistas, adequadas à idade da criança tanto no sentido do conteúdo (semantismo) quanto no sentido sintático (tamanho).

Enfim, a proposta é constituir exercícios que promovam a CF para as crianças cegas, buscando auxiliá-las na aquisição da ortografia oficial da Norma Padrão. Dessa maneira, acreditamos que estas crianças podem até escolher outros suportes de comunicação, a gravação, por exemplo, mas estará apta também a se utilizar do sistema de escrita voltado especificamente para ela.

\section{CONSIDERAÇÕES FINAIS}

Neste artigo, iniciamos com a definição do que se entende por deficiência visual como ponto inicial da nossa discussão. A seguir tratamos do sistema de escrita voltado para pessoas cegas, ressaltando algumas das suas características principais. Depois abordamos a questão da ortografia e da sua importância na comunicação escrita tanto para videntes quanto para cegos. Por fim, apontamos os resultados de trabalhos de consciência fonológica em crianças videntes e buscamos fazer uma reflexão acerca de um trabalho com crianças cegas. 
Acreditamos que com o percurso realizado trazemos à discussão a questão do trabalho com a ortografia oficial para crianças que utilizem o sistema Braille. Acreditamos que saber escrever dentro das regras exigidas para a escrita é importante tanto para o percurso escolar quanto para a inserção no mercado de trabalho. No entanto, não é dizendo que elas erram que teremos uma escrita satisfatória. É preciso criar meios para que adquiram a ortografia da Norma Padrão. Acreditamos que além de leitura de livros em Braille, trabalhar com exercícios de consciência fonológica poderá facilitar bastante o processo de apreensão das regras de ortografia.

\section{REFERÊNCIAS}

ALEGRE, M. J. A deficiência visual. 2006. Disponível em: < http://www.drec.min-edu.pt/ nadv/txt-adeficienciavisual.htm>. Acesso em: 14 jun. 2006.

ALMEIDA, M. da G. S. Alfabetização: uma reflexão necessária. 2005. Disponível em: http:/ www.ibc.gov.br/?itemid=394\# more> Acesso em: 10 abr. 2006.

BAPTISTA, J. A. O sistema braille e a sua importância na vida dos cegos. 2000. Disponível em: < http://www.lerparaver.com/braille_invencao.html>. Acesso em: 26 jul. 2007.

BARRERA, S. D.; MALUF, M. R. Consciência metalingüística e alfabetização: um estudo com crianças da primeira série do ensino fundamental. Psicologia: Reflexão e Crítica, Porto Alegre, v. 16, n. 3, 2003. Disponível em: < http://www.scielo.br/ scielo.php? script $=$ sci_arttext\&pid $=$ S0102-79722003000300008\&lng $=$ pt\&nrm $=$ iso $>$. Acesso em: 27 maio 2006.

CAGLIARI, L. C. Alfabetização e Lingüística. São Paulo: Scipione, 1997.

CAIADO, K. R. M. Aluno deficiente visual na escola: lembranças e depoimentos. Campinas: Autores Associados; PUC, 2003. (Coleção Educação Contemporânea)

CAPOVILlA, A. G. S.; CAPOVILLA, F. C. Efeitos do treino de consciência fonológica em crianças com baixo nível sócio-econômico. Psicologia: Reflexão e Crítica, Porto Alegre, v. 13, n. 1, 2000. Disponível em: < http://www.scielo.br/scielo. php? script=sci_arttext\&pid $=\mathrm{S} 010279722000000100003 \& \operatorname{lng}=$ pt\&nrm $=$ iso $>$ Acesso em: 17 jun. 2006 .

CARDOSO-MARTINS, C. Consciência fonológica e habilidade de leitura na síndrome de down. Psicologia: Reflexão e Crítica, Porto Alegre, v. 12, n. 1, 1999. Disponível em: $<$ http://www.scielo.br/scielo.php?script=sci_arttext\&pid=S010279721999000100014 $\& \operatorname{lng}=$ pt\&nrm $=$ iso $>$. Acesso em: 01 maio 2007.

CARNIO, M. S.; SANTOS, D. dos. Evolução da consciência fonológica em alunos de ensino fundamental. Pró-Fono Revista de Atualização Científica, Barueri, v. 17, n. 2, p. 195200, maio-ago. 2005. Disponível em: <http://www.scielo.br/scielo. php?script =sci_ arttext\&pid $=$ S0104-56872005000200008\&lng $=$ pt\&nrm $=$ iso $>$. Acesso em: 17 jun. 2006. 
HORTON, J. K. Educação de alunos deficientes visuais em escolas regulares. 2006. Disponível em: < http://www.drec.min-edu.pt/nadv/txt-educacaoescolasregulares.htm > Acesso em 14 jun. 2006. 


\title{
A INSTITUCIONALIZAÇÃO DO SOROBAN NA ESCOLA E A GÊNESE INSTRUMENTAL POR APRENDIZES CEGOS
}

\author{
Aida Carvalho Vita \\ Afonso Henriques \\ Irene Maurício Cazorla
}

\section{INTRODUÇÃO}

Na Conferência Mundial sobre Educação para Todos, realizada na Tailândia, em 1990, com o propósito de repensar a situação mundial da Educação, foi firmado em documento o compromisso de garantir educação básica de qualidade para crianças, jovens e adultos, sem exceção. Este documento, em seu artigo $1^{\circ}$, segundo informa Ferronato (2002, p. 17) expõe:

Cada pessoa - criança, jovem ou adulto - deverá poder aproveitar as oportunidades educativas destinadas a satisfazer suas necessidades básicas de aprendizagem. Essas necessidades englobam tanto as ferramentas essenciais para aprendizagem (tais como alfabetização, expressão oral, cálculo e solução de problemas) como os conteúdos básicos da aprendizagem (conhecimentos, habilidades, valores e atitudes).

Somando-se a essas determinações, o artigo $3^{\circ}$ dessa declaração, sinaliza para as necessidades de aprendizagem dos deficientes, recomendando a adoção de medidas que garantam a igualdade de acesso à Educação aos portadores de todo, e, qualquer tipo de deficiência. Por deficiência entendemos uma restrição 
ou carência física, mental ou sensorial, de natureza permanente ou transitória, podendo ser causada ou agravada pelo ambiente econômico e/ou social.

No ano de 1994 aconteceu a Conferência Mundial sobre Necessidades Educativas Especiais, em Salamanca - Espanha, onde se reconheceu a escola regular como o meio mais capaz de combater atitudes discriminatórias e de construir uma sociedade inclusiva atingindo a Educação para Todos (FERRONATO, 2002).

No Brasil, especificamente os princípios norteadores da Declaração de Salamanca têm respaldo legal na Lei de Diretrizes e Bases da Educação Nacional, n. 9.394, de 20 de dezembro de 1996. Seu Capitulo V, Artigo 58, define a educação especial como a modalidade de educação escolar, oferecida preferencialmente na rede regular de ensino para educandos portadores de necessidades especiais (BRASIL, 1996).

A instituição dessas leis tem feito aumentar a procura dos deficientes visuais por vagas nas escolas da rede regular de ensino, a partir da década de 90 do século passado, como demonstram os dados publicados pelo Instituto Nacional de Estudos e Pesquisas Educacionais Anísio Teixeira (INEP).

No entanto, essa nova demanda tem exigido grandes desafios da escola, que nem sempre dispõe de uma estrutura apropriada para realizar um fazer pedagógico adequado, tal como apontado pelos Parâmetros Curriculares Nacionais (PCN) para a educação especial (BRASIL, 1998). Nesse sentido, salientam os PCN que tanto a escola, quanto o aluno devem se aprimorar para alcançar a eficiência da educação a partir de uma interatividade mútua.

Amparados por um conjunto de ações governamentais para promover a inclusão de todos, voltamos nosso interesse sobre a inclusão de alunos cegos em escolas regulares, buscando conhecer o processo de institucionalização ${ }^{1}$ escolar de suas ferramentas de aprendizagem em Matemática. As reflexões aqui apresentadas fazem parte de um projeto maior de educação inclusiva que visa à institucionalização das diversas ferramentas utilizadas para a aprendizagem da Matemática por alunos portadores de deficiências, dentre eles os alunos cegos, surdos e com Síndrome de Down. Trata-se do projeto TEIAS da Inclusão: Traçando a Educação Inclusiva e Acessível, desenvolvido pelo Grupo de Pesquisa em Educação Matemática, Estatística e em Ciências (GPEMEC), da Universidade Estadual de Santa Cruz (UESC), financiado pela Fundação de Apoio à Pesquisa do Estado da Bahia (Fapesb), do qual fazemos parte.

\footnotetext{
${ }^{1}$ Entendemos por institucionalização a utilização e aceitação de forma democrática das ferramentas de aprendizagem matemática de alunos com necessidades educacionais especiais.
} 
Observamos a escassez de pesquisas que investigam o Soroban como recurso educativo utilizado para ensinar matemática a alunos com deficiência visual. Nesse sentido, pontuamos algumas questões sobre sua institucionalização em escolas públicas regulares e inclusivas do sul da Bahia.

\section{O SOROBAN}

A Portaria n. 1.010, 11 de maio de 2006 do Ministério da Educação (MEC), baseado no parecer da Comissão Brasileira de Estudo e Pesquisa do Soroban ${ }^{2}$ o instituiu como um recurso educativo específico imprescindível para a execução de cálculos matemáticos por alunos com deficiência visual (BRASIL, 2006).

O Soroban é um ábaco japonês que significa "bandeja de cálculo", seu formato é retangular e composta por várias hastes verticais, onde estão presas cinco contas separadas por uma barra central, que o divide em dois retângulos, um inferior que contém quatro contas de valor um e, um superior, que contém uma conta de valor cinco correspondente em cada ordem (PEIXOTO; SANTANA; CAZORLA, 2006, p. 19).

Com essa ferramenta podemos realizar diversos tipos de operações, tais como: de soma e subtração, multiplicação e divisão, bem como técnicas de extração de raízes, juros, porcentagem, dentre outros. Emprega o Sistema de Numeração Decimal (SND) atribuindo a cada haste uma potência de dez $\left(\ldots, 10^{-3}, 10^{-2}, 10^{-1}, 10^{0}, 10^{1}, 10^{2}, 10^{3}\right.$, $\left.10^{4}, \ldots\right)$ da direita para a esquerda. Diz-se que está zerado ou "limpo" quando não há nenhuma representação numérica nele, ou seja, todas as contas estão afastadas da barra central. A cada três hastes da direita para a esquerda tem um ponto saliente, chamado ponto de referência que indica a ordem das unidades de cada classe (unidades simples, unidades de milhar, unidades de milhão...), conforme a Figura 1.

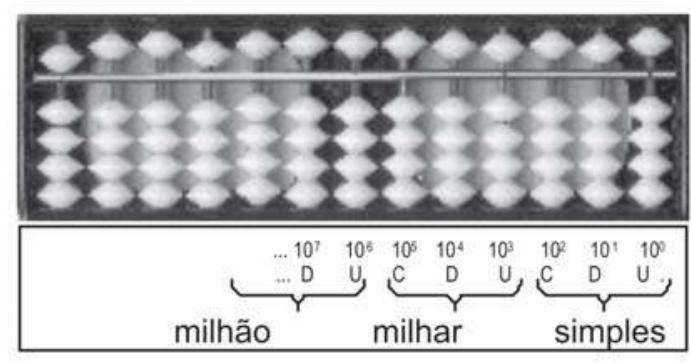

Figura 1 - Soroban moderno

Fonte: Peixoto et al., 2006, p. 15.

\footnotetext{
${ }^{2}$ Nomeada pela Portaria Ministerial no 657, de 07 de março de 2002.
} 
Essa ferramenta foi aprimorada para ser utilizada por deficientes visuais, sendo a principal diferença, um dispositivo para fixar as contas em determinada posição, pois a leitura dos valores é feita pelo tato e as contas não podem deslizar livremente como no Soroban convencional. Para facilitar a leitura, na barra central e na moldura existem pontos e traços em alto relevo para indicar respectivamente as ordens e a mudança de classe.

O Soroban brasileiro, adaptado e enviado pelo MEC para as escolas ( $\mathrm{Fi}$ gura 2) possui um tapete de borracha no fundo que fixa as contas quando são registrados os valores (PEIXOTO et al., 2006, p.22).

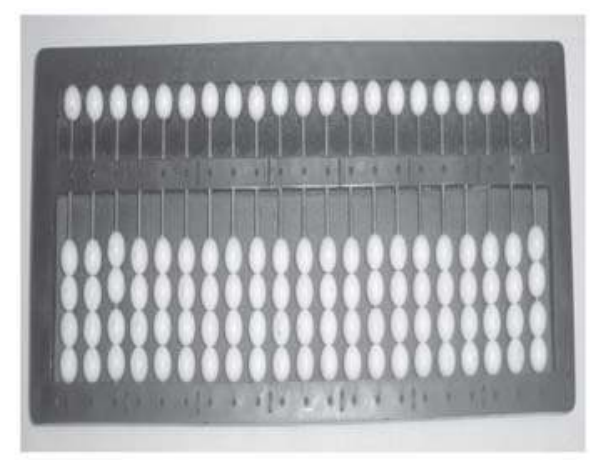

Figura 2 - Soroban brasileiro adaptado, produzido pela Bengala Branca.

Fonte: Peixoto; Santana; Cazorla, 2006.

\section{O SOROBAN, DE FERRAMENTA A INSTRUMENTO DE APRENDIZAGEM}

Para compreender como uma ferramenta pode se transformar em instrumento, capaz de potencializar a aprendizagem de conceitos matemáticos por aprendizes cegos, utilizamos a teoria de instrumentação de Rabardel (1995). Este teórico propôs uma abordagem de modelização didática em que distingue ferramenta (artefato) o que é fornecido ao sujeito e instrumento o que é construído pelo sujeito na relação com a ferramenta.

Para a análise de atividades com instrumentos, Rabardel (1995) propôs uma abordagem de modelização didática, proveniente de trabalhos em ergonomia. ${ }^{3}$ Nesta abordagem, o autor distingue essencialmente a ferramenta

\footnotetext{
${ }^{3}$ Estudo técnico da relação entre o homem e o equipamento de trabalho ou o meio em que ocorre esse trabalho.
} 
(artefato) como o que é fornecida ao sujeito, do instrumento que é construído pelo sujeito na relação com a ferramenta. A transformação de ferramentas em instrumentos articula o sujeito, com suas habilidades e competências cognitivas, com a ferramenta que tem suas características próprias e com o objeto para a qual a ação é dirigida.

Rabardel (1995) e Verillon (1996) propuseram o Modele dês situations d'activités avec instrumental (SAI), que nos permite delinear as relações entre o sujeito e o objeto sobre o qual ele age (Figura 3) evidenciando quatro interações que interferem nessas atividades, representadas através das flechas: sujeito-instrumento [S-i], sujeito-objeto [S-O], instrumento-objeto $[\mathrm{i}-\mathrm{O}]$ e a relação sujeito-objeto mediado pelo instrumento [S(i)-O].

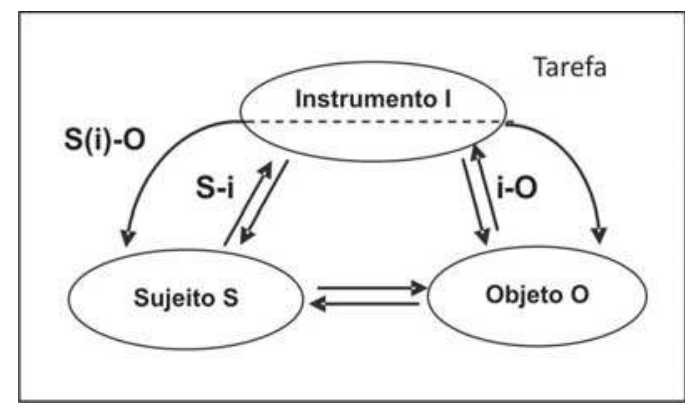

Figura 3 - Modelo de Situações de Atividades Instrumentais - SAI.

Fonte: Rabardel, 1995.

O Modelo SAI em nossas investigações foi estruturado conforme Figura 4. Assim, o sujeito é o deficiente visual, a ferramenta o Soroban e o objeto matemático as operações fundamentais. Na relação [S-O] buscamos conhecer os procedimentos utilizados pelo deficiente visual (S) nas quatro operações fundamentais $(\mathrm{O})$; na relação [S-i] queremos conhecer como o deficiente visual lida com o Soroban; na relação [I-O] investigamos o potencial do instrumento para a aprendizagem das operações fundamentais, e por fim, a relação [S(i)-O] investigamos o envolvimento do deficiente visual (S), as quatro operações fundamentais (O) utilizando para tanto, o Soroban (I). 


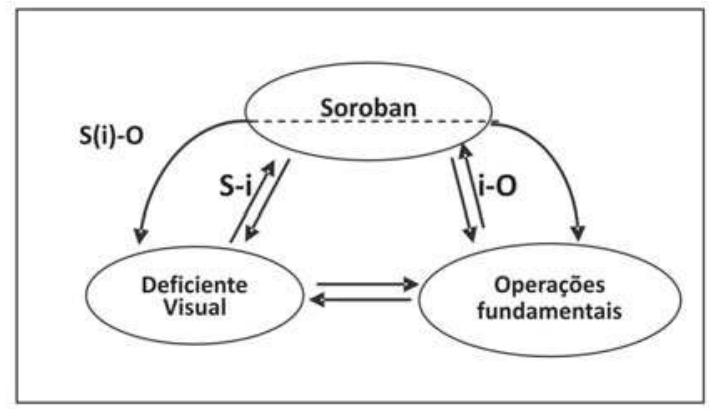

Figura 4 - Modelo de SAI na pesquisa.

Concordamos com Vygotsky (2000) que a relação do homem com o mundo é mediada pelos instrumentos e signos. No caso específico da deficiência visual, o conhecimento é mediado basicamente pelo sistema auditivo/fonador e pelo sistema háptico/tato ativo.

Neste contexto, o modelo SAI nos permite, por um lado, compreender o papel mediador do Soroban na aprendizagem das operações fundamentais por alunos cegos e, por outro, investigar o potencial desse recurso didático nas operações fundamentais e como o Soroban atua como um instrumento para fazer pensar, permitindo diferentes formas de registro numérico.

Esses conhecimentos nos possibilitam contribuir para institucionalização dessa ferramenta na escola regular, bem como, estimular os professores a fazerem uso deste instrumento em seu trabalho pedagógico, incluindo os alunos cegos e seus instrumentos. No entanto, esse trabalho demanda um processo de adaptação e conscientização de todos os envolvidos nessas escolas para as necessidades do aluno cego, minimizando os desafios em seu processo de aprendizagem da Matemática.

\section{CAMINHO PERCORRIDO}

Nesta sessão apresentamos o caminho que já percorremos em nossas investigações com o Soroban em escolas regulares, caracterizadas como inclusivas no Sul da Bahia. Inicialmente, investigamos sobre o uso do Soroban, no ano de 2007 em cursos de Formação Continuada para professores de 27 municípios do sul da Bahia. Foram localizados cerca de 500 professores que ensinam Matemática (Licenciados em Matemática e Pedagogos). 
Com relação aos alunos cegos observamos que nas operações com pequenas quantidades, eles utilizam diversas coleções de objetos, memorizam as tabuadas e operam através do cálculo mental. Quando os cálculos envolvem grandes quantidades, os alunos utilizam o Soroban; contudo, o utilizam apenas para registrar os resultados, em geral, por meio do algoritmo tradicional.

Com relação aos professores, a maioria deles sequer sabia o significado da palavra Soroban. Também ficou evidente nas falas dos professores o reconhecimento da importância do Soroban, a reglete e o punção, como ferramentas indispensáveis para o aprendiz cego, porém eles os desconheciam. Apontaram que durante sua formação inicial, eles não tiveram acesso a esses conhecimentos e, que ainda hoje, os cursos de Licenciatura em Matemática ou em Pedagogia, não incorporaram seu ensino nos seus currículos.

Outro fato que constatamos nas escolas regulares dos municípios do Sul da Bahia é que o ensino do Soroban para alunos cegos, de um modo geral, tem sido feito pelo professor pedagogo da sala de apoio e não pelo professor regente da disciplina de Matemática. Assim, de um lado, o professor de Matemática que detém o conhecimento matemático não sabe usar o Soroban; do outro, o responsável pela sala de apoio, que conhece o Soroban, não tem a formação matemática que lhe permita explorar essa ferramenta em sua plenitude. Os alunos cegos, os mais interessados pela aprendizagem do uso do Soroban ficam a mercê dessas realidades.

Além disso, observamos que quando o Soroban é ensinado, isso é feito reproduzindo os algoritmos tradicionalmente ensinados na escola, sem explorar suas potencialidades.

Neste contexto, os alunos cegos vão articulando maneiras de fazer os cálculos com o Soroban utilizando esses algoritmos. Ilustrando as nossas investigações quanto à relação [S-O ] e [S-(i)-O] apresentamos o caso da aluna Luzia, do $1^{\circ}$ ano do Ensino Médio de uma escola pública de Itabuna-BA, a qual para resolver uma operação de multiplicação realizou os seguintes procedimentos: registrou as parcelas em Braile e, na sequência, no Soroban, prosseguindo fez a multiplicação no Soroban utilizando o algoritmo tradicional da ordem menor para a maior. Simultaneamente ao uso do Soroban Luzia utilizou o cálculo mental e seus próprios dedos que serviram de instrumentos auxiliares da operação.

De acordo com o modelo SAI, na relação [I-O] uma exploração plena do uso do Soroban nas operações fundamentais implicaria em acolher o Soroban como um instrumento que permite uma flexibilidade nas formas de operar, 
facilitando os cálculos e permitindo que as operações sejam feitas de uma ordem menor para uma maior ou vice-versa.

\section{CONSIDERAÇÕES FINAIS}

Ao longo de nossas incursões na pesquisa sobre a institucionalização escolar do Soroban na região de influência da Universidade Estadual de Santa Cruz (UESC), observamos que essa ferramenta é ainda desconhecida de muitos professores que ensinam Matemática (Licenciados em Matemática e em Pedagogia).

A presença, cada vez maior, de alunos cegos, surdos, dentre outros com necessidades educacionais especiais nas escolas regulares já é uma realidade. Contudo, ainda não há garantias de que esses alunos estejam minimamente apreendendo os conhecimentos científicos aos quais tem direito.

Nesse sentido, todos os atores educacionais devem estar conscientes de que se queremos uma escola inclusiva, devemos trabalhar em todas as frentes. Desde a formação inicial dos professores, nos cursos de Licenciatura em Matemática e Pedagogia até os cursos de pós-graduação e extensão; formando parcerias de investigação entre a escola e a universidade, dado o tamanho do desafio da construção de uma escola para todos.

Assim, o Modelo SAI, apresenta-se como um possível caminho de pesquisa e ação didática para que a ferramenta Soroban se transforme em instrumento escolar de aprendizagem de conceitos matemáticos, na medida em que nos permite conhecer como o aprendiz cego lida com o objeto matemático mediado pelo instrumento.

Os cursos de Licenciatura em Matemática e Pedagogia, principais formadoras de professores que ensinam Matemática, precisam incorporar em seus currículos o uso de ferramentas que possam contribuir na apropriação do conhecimento matemático por aprendizes cegos. Entretanto, o uso do Soroban não pode, nem deve ser restrito para os alunos cegos, tendo em vista, que esta ferramenta traz no seu bojo formas alternativas de operar com os números.

Assim, podemos concluir que a existência de uma portaria do MEC que institui o Soroban como ferramenta de cálculo do cego e de outros documentos oficiais que defendem o direito à educação para todos, não é suficiente para que isso se torne uma realidade na escola. 
A institucionalização escolar de ferramentas que auxiliem a aprendizagem de alunos cegos é uma tarefa de todos os envolvidos no processo educativo, pesquisadores, professores, pais, alunos e comunidade.

Por fim, consideramos que o presente trabalho traz reflexões sobre a institucionalização do Soroban na escola básica, mas que podem ser inferidas para todo o processo da construção de uma escola realmente inclusiva.

\section{REFERÊNCIAS}

BRASIL. Lei n. 9.394, de 20 de dezembro de 1996. Estabelece as diretrizes e bases da educação nacional. Brasília, 1996. Disponível em: < http://portal.mec.gov.br/seesp/ index.php?option $=$ content\&task $=$ view\&id $=159 \&$ Itemid $=311>$. Acesso em: 15 jul. 2007.

BRASIL. Ministério da Educação. Secretaria de Educação Especial. Portaria n. 1.010, de 11 de maio de 2006. Disponível em: < http://www.universia.com.br/html/noticia/ noticia_dentrodocampus_cjfcg.html>. Acesso em: 05 de jul. 2007.

BRASIL. Ministério da Educação. Secretaria de Educação Fundamental. Parâmetros Curriculares Nacionais: adaptações curriculares. Brasília, 1998.

FERRONATO, R. A construção de instrumento de inclusão no ensino da Matemática. 2002. Dissertação (Mestrado em Engenharia de Produção). Universidade Federal de Santa Catarina, Florianópolis, 2002.

HENRIQUES A.; ATTIE J. P.; FARIAS L. M. S. Referências teóricas da didática francesa: análise didática visando o estudo de integrais múltiplas com auxílio do software Maple. Educação Matemática Pesquisa, v. 9, n.1, p.51-81, 2007.

PEIXOTO, J. L. B.; SANTANA, E. R. dos S.; CAZORLA, I. M. Soroban: uma ferramenta para a compreensão das quatro operações. Itabuna: Via Litterarum, 2006.

RABARDEL, P. Les hommes et les technologies: approche cognitive des instruments contemporains. Paris: Armand Colin, 1995.

RABARDEL, P. Qu'est-ce qu'un instrument? Appropriation, conceptualisation, mises en situation. In: Outils pour le calcul et le traçage de courbes CNDP-DIE - mar. 1995.

Disponível em: < http://www.cndp.fr/archivage/valid/13420-1126-1194.pdf.>. Acesso em: 10 de mar. 2008.

VERILLON, P. La problématique de l'enseignement: un cadre pour penser l'enseignement du graphisme, Revue GRAF \& TEC. v. 0, n. 0, 1996. 



\section{REPRESENTAÇÕES CONCEITUAIS NA PRÁTICA EDUCATIVA ESPECIAL E INCLUSIVA DO PROFESSOR DE EDUCAÇÃO FÍSICA}

Chrystiane Vasconcelos Andrade Toscano

Rita de Cácia Santos Souza

\section{INTRODUÇÃO}

Ao longo do tempo tornou-se quase comum associar a prática do profissional de Educação Física, que atuava com pessoas com algum tipo de necessidade educacional especial, a uma ação corretiva, higienista e reabilitadora. Talvez esse fato tenha sido produto dos programas desenvolvidos no Brasil, a partir da década de 1950, denominados Educação Física Preventiva, Ortopédica, Reabilitativa e Terapêutica. A partir da década de 1980, segundo Pedrinelli e Verenguer (2005), os programas assumiram identidade essencialmente pedagógica e passaram a constituir-se enquanto intervenção pedagógica individual ou coletiva responsável pelo desenvolvimento motor do alunado que apresentasse necessidade educacional especial nas escolas com turmas especiais e/ou inclusivas.

No município de Aracaju-SE, a disciplina curricular Educação Física, ofertada nas instituições de ensino especiais e inclusivas, apresentou-se como uma ação pedagógica histórica de inclusão-exclusão daqueles considerados legalmente como pessoas com necessidades educacionais especiais. Diante deste contexto nos questionamos: Como os professores de Educação Física têm percebido a inclusão de alunos com necessidades educacionais especiais, em sua prática pedagógica, a partir da dimensão conceitual de educação, educação especial 
e inclusiva? Tentando refletir sobre a questão, buscou-se neste estudo compreender e analisar esses conceitos a partir do olhar dos professores de Educação Física que vivenciam o processo de inclusão de alunos com necessidades educacionais especiais.

É preciso declarar que neste estudo considerou-se a escola como instituição social e cultural atenta à proposta de uma pedagogia inclusiva discutida e debatida desde a Declaração de Salamanca em 1996.

No Brasil, a proposta inclusiva é orientada a partir de dois importantes documentos. O primeiro, refere-se a Lei de Diretrizes e Bases da Educação Nacional n. 9.394, de 20 de dezembro de 1996, cujo texto recebe maior detalhamento nas Diretrizes Educacionais elaboradas pela Secretaria de Educação Especial do Ministério da Educação (SEESP/MEC) no ano de 1998. No entanto, deve-se considerar que a elaboração da referida legislação motivou novos olhares acerca das possibilidades e dificuldades arquitetônicas e sociais na atenção às necessidades educacionais especiais do alunado incluído na escola regular. E que o período em estudo está imerso na criação dessas leis e perspectivas de mudanças, o que faz com que as análises sejam percebidas como expressões de um processo em construção. Ou seja, é uma análise que não pretende apontar vilões e heróis, mas personagens e suas compreensões num determinado tempo e contexto histórico. Neste sentido, faz-se fundamental considerar que a inclusão dos alunos com necessidades educativas especiais clama a toda comunidade escolar o reconhecimento do direito à diferença e principalmente a necessidade de redefinição da função social da escola a partir da cultura escolar onde e quando se manifesta.

As atitudes, vistas como positivas e/ou negativas, dos educadores, frente a turmas inclusivas e especiais são frutos de suas representações sociais determinadas pelas percepções sociais que não são neutras. Segundo Chartier (1990) as representações sociais são exibições de uma presença, isto é, exposições públicas de alguém ou de algo. Desta forma, é possível perceber que a identificação do olhar dos professores de Educação Física acerca do processo de inclusão de escolares com necessidades educacionais especiais em sua prática pedagógica possibilitou um aprofundamento das representações que os grupos de professores visualizaram deles próprios e dos outros. Consideramos que somente poderão ser construídas atitudes positivas quando houver a formação adequada da comunidade escolar para compreender o sentido da escola como instituição social e cultural. Nesta direção Mosqueta (1993, p.25) nos alerta que "a instituição educacional necessita preparar sua comunidade escolar para escolher tarefas de 
aprendizagens adequadas, ajudar os alunos a estabelecer objetivos e ensinar os alunos a orientar-se para o domínio de tarefas."

De acordo com Ghiraldelli Júnior (1994) e Bracht (1987) a Educação Física passou a ser obrigatória nas escolas brasileiras em 1937. Sua função foi inicialmente preparar a juventude para o combate, a luta e a guerra. Os conteúdos priorizados nas aulas de Educação Física eram a ginástica, o desporto e os jogos recreativos, estes teriam a função exclusiva de preparar fisicamente o cidadão soldado. Neste cenário dois sujeitos merecem um destaque especial, são eles: o aluno e o professor de Educação Física. O primeiro deles era avaliado pelo corpo que possuía, este era socialmente aceito se demonstrasse capacidade produtiva ideologicamente determinada e o segundo deles era considerado o técnico, aquele capaz de desenvolver as habilidades físicas do educando. De acordo com os estudos de Cantarino Filho (1982) a concepção de uma Educação Física voltada à aptidão física foi um dos elementos que privou em 1938 a pessoa com algum tipo de necessidade educacional especial de ter acesso a escolarização.

Segundo o referido autor, a portaria n. 13, de 01 de fevereiro de 1938 do Ministério de Educação estabelece: "a proibição da matrícula em qualquer estabelecimento de ensino secundário de aluno cujo estado patológico o impedisse, permanentemente, das aulas de Educação Física" (CANTARINO FILHO, 1982, p. 32). Esta portaria, atrelada a uma concepção biológica e a uma metodologia rígida e autoritária da Educação Física, não favoreceu vivências inclusivas nas aulas de Educação Física durante as décadas de 1930 e 1940.

A citação da Educação Física no III Plano Setorial de Educação Física em 1980, documento expedido pelo Centro Nacional de Educação Especial e a Coordenadoria Nacional para Integração da Pessoa Portadora de Deficiência (CORDE), foi de suma importância para incorporação das aulas de Educação Física em escolas especiais e inclusivas dirigidas aos sujeitos com necessidades educacionais especiais. Este documento foi publicado pelo Ministério da Educação após uma capacitação dirigida exclusivamente a professores de Educação Física em 1980 nas regiões Sul, Sudeste e Nordeste do país. Esta medida foi fruto da expansão internacional do esporte adaptado neste período. Outro documento também importante foi um Manual de Destrezas em cada Modalidade Esportiva produzido e distribuído pela CORDE no mesmo período. Os referidos documentos demonstraram o 
quanto era importante para o país ter representantes nas Olimpíadas Especiais, daí a grande preocupação dos órgãos governamentais em elaborar subsídios para atenção dos sujeitos com necessidades educativas especiais nas aulas de Educação Física.

No Estado de Sergipe houve, a partir deste período, algumas iniciativas isoladas de profissionais da Educação Física que atuavam com práticas esportivas como a dança, o atletismo e a natação. A vontade de realizar uma intervenção pedagógica dirigida ao desenvolvimento de habilidades e competências das pessoas com necessidades educacionais especiais motivou os professores a organizarem turmas de crianças com deficiência mental, para vivenciar a dança, e com deficiência visual para a prática do atletismo e natação na década de 1990. A participação destes alunos em campeonatos esportivos escolares possibilitou a visualização de alternativas procedimentais na atenção às necessidades especiais.

\section{METODOLOGIA}

Para o desenvolvimento deste estudo optamos pela pesquisa do tipo descritiva uma vez que a mesma, segundo Triviños (1987), exige uma fundamentação teórica consistente sobre o que se deseja pesquisar e uma precisa delimitação dos sujeitos da pesquisa, de técnicas, métodos e teorias as quais orientaram a coleta e interpretação dos dados.

O grupo deste estudo foi constituído por 32 professores de educação física, dos quais 26 eram de escolas estaduais e municipais inclusivas e seis de escolas estaduais especiais.

O coletivo de professores selecionados apresentava, em suas turmas de Educação Física, sujeitos com necessidades educativas especiais durante o período de realização da pesquisa (2000-2002). De acordo com declarações emitidas pelos Departamentos de Educação, da rede de ensino estadual de Sergipe e municipal da cidade de Aracaju, as instituições públicas perfizeram um total de 12 instituições, sendo uma de educação especial e onze de educação inclusiva na capital do Estado. A coleta de dados para efeito metodológico foi realizada em três momentos. No primeiro momento foi realizada a análise de documentos em órgãos de planejamento e de organização da Educação Especial e Inclusiva da Rede de Ensino Municipal e Estadual. Os órgãos visitados foram: o Departamento de Educação de Aracaju (DEA), a Divisão de Educação Especial (DIEESP), 
o Departamento de Educação Física (DEF), o Centro de Apoio Pedagógico para o Atendimento à Pessoa com Deficiência Visual (CAP) e o Departamento de Educação Especial da Secretaria Municipal de Aracaju (DEESP-SEMED). Os documentos analisados foram: Censos escolares de 2000 a 2002, Controle da Educą̧ão Especial na Rede Estadual de Ensino, Relação dos Professores de Educação Física lotados em Escolas Especiais e Inclusivas e Catálogo das Escolas Municipais de Aracaju.

No segundo momento realizou-se entrevistas semiestruturadas e três observações sistematizadas com duração de 30 a 50 minutos em cada uma das turmas. No terceiro momento, foi realizada a análise e discussão dos resultados.

\section{RESULTADOS E DISCUSSÃO}

A inexistência de estudos que discutam a trajetória dos professores de educação física no processo de educação inclusiva permitiu a valorização do uso dos depoimentos dos sujeitos de estudo como elementos essenciais para construção de uma possível análise da temática. Le Goff (1994, p. 540) defende a ideia de que "a história faz-se com documentos escritos, sem dúvidas, quando estes existem. Mas pode fazer-se, deve fazer-se sem documentos escritos, quando não existem [....."

De acordo com os depoimentos dos sujeitos de estudo ao longo do tempo a prática pedagógica do profissional de Educação Física, de instituições especiais e inclusivas da cidade de Aracaju-SE, foi associada a uma ação psicomotora. Os cursos de pós-graduação e os de aperfeiçoamento, financiados na década de 1990 pela Secretaria da Educação do Estado de Sergipe, ofereceram subsídios teórico-metodológicos de Escolas psicomotoras francesa e russa a partir de um convênio internacional entre a Secretaria do Estado da Educação de Sergipe e o Ministério de Educação de Cuba.

Os relatos expressaram que as orientações metodológicas não atendiam, em todos os aspectos, a realidade do coletivo de alunos incluídos em turmas regulares. Este fato justifica-se pela valorização excessiva, durante o desenvolvimento dos cursos supra-mencionados, da fundamentação teórica. Segundo um dos depoentes "a fundamentação teórica é importante mas é preciso que ela parta dos contextos."

No que se refere à representação do conceito de educação, para os professores de educação física da unidade de ensino especial pode-se constatar que: 


\begin{tabular}{|c|c|}
\hline $\begin{array}{l}\text { Número de } \\
\text { Professores }\end{array}$ & Categoria de Resposta dosProfessores da Escola Especial \\
\hline 05 & Todo conhecimento apreendido por nós ao longo de nossa vida. \\
01 & Conjunto de conhecimentos que aprendemos em nossas relações sociais. \\
\hline
\end{tabular}

Quadro 1 - Concepção de Educação

A partir da análise dos conceitos apresentados realizaram-se observações para ampliar a interpretação das apropriações e representações do olhar dos professores de educação física na sua prática pedagógica. Pode-se constatar, a partir dos registros, que as atitudes dos professores permitiram identificar que os procedimentos metodológicos utilizados estavam adequados às necessidades educacionais especiais do alunado atendido na instituição especializada. A oferta de instrumentos adequados para experimentação de desafios motores, apresentados no desenvolvimento dos conteúdos de ensino da disciplina educação física, demonstrou ampliação do repertório de conhecimentos do aluno que poderão ser transferidos para o seu cotidiano. A valorização das produções coletivas e a diversificação dos ambientes sociais extraescolares dinamizaram o processo ensino-aprendizagem podendo assim, preparar a pessoa com necessidade educacional especial a desenvolver estratégias de sobrevivência diante de experiências de exclusão social.

Os resultados das entrevistas realizadas nas instituições públicas inclusivas demonstraram que:

\begin{tabular}{|c|r|}
\hline $\begin{array}{l}\text { Número de } \\
\text { Professores }\end{array}$ & Categoria de Resposta dosProfessores da Escola Inclusiva \\
\hline 18 & Todo conhecimento apreendido por nós dentro da escola... \\
08 & Todo conhecimento aprendido pelo aluno dentro e fora da escola. \\
\hline
\end{tabular}

Quadro 2 - Concepção de Educação

A partir dos depoimentos dos 18 professores das escolas inclusivas podese perceber que suas representações declaram uma concepção behaviorista de 
educação cujo objetivo educacional limita-se a transmissão de conhecimentos selecionados pela cultura dominante. As falas de oito entrevistados apontam para um conceito de educação mais ampliado ao afirmarem que educação é "tudo aquilo que aprendemos dentro e fora da escola." Nesta perspectiva emergem novos olhares em direção a uma cultura de educação em respeito à diversidade.

Os registros comprovam que é possível coabitar com diferentes concepções de educação no ambiente escolar muito embora saibamos que o desenvolvimento de uma proposta inclusiva exige sintonia de representações. Eles indicam ainda que a representação do conceito de educação ainda se limita ao reconhecimento da instituição escolar como aquela cuja responsabilidade é preparar o sujeito para a vida. Concepções que podem ter sido apropriadas na sua trajetória de educação formal e informal. No entanto, deve-se reconhecer que a adoção deste conceito pode limitar a ação do docente, pois ele a partir desse olhar poderá encontrar dificuldades de, solitariamente, vislumbrar metas que possam efetivar um projeto voltado para o que se propõe a educação inclusiva.

No que se refere ao conceito de educação especial os resultados das entrevistas demonstraram diferentes concepções. Segundo o coletivo de professores das escolas especiais:

\begin{tabular}{|c|r|}
\hline $\begin{array}{l}\text { Número de } \\
\text { Professores }\end{array}$ & Categoria de Resposta dosProfessores da Escola Especial \\
\hline 04 & Todo conhecimento apreendido por nós dentro da escola. \\
02 & Educação especializada que prepara o deficiente para ser incluído na \\
sociedade.
\end{tabular}

Quadro 3: Concepção de Educação Especial

É preciso reconhecer que este tema foi e ainda continua sendo um obstáculo à integ ração das pessoas com necessidades educacionais especiais. $\mathrm{O}$ direito à educação de qualidade, para aqueles que apresentam algum tipo de necessidades educacionais especiais, não é apenas encontrado em ambientes exclusivos, como são as instituições especiais, pois se assim fosse não teríamos problemas extra-muros escolares de adaptação quando o aluno finalizasse seu processo de atenção especializada. Não é possível a criação de dois mundos, um para aqueles que não são diagnosticados como sujeito com necessidades educacionais es- 
peciais e outro para aqueles que apresentam necessidades educacionais especiais.

Buscando ampliar os dados, perguntamos aos professores de Educação Física de instituições inclusivas acerca de suas concepções de educação especial. Segundo os depoentes:

\begin{tabular}{|c|r|}
\hline $\begin{array}{l}\text { Número de } \\
\text { Professores }\end{array}$ & Categoria de Resposta dosProfessores da Escola Inclusiva \\
\hline 16 & Educação dirigida a pessoas que não tem condições de frequentar \\
uma escola para normais \\
10
\end{tabular}

Quadro 4: Concepção de Educação Especial

Diante dos dados apresentados pode-se inferir que a ênfase do conceito relaciona-se exclusivamente a necessidade educacional especial. Não houve na fala dos entrevistados qualquer relação das potencialidades desta escola enquanto instituição socialmente capaz de integrar o aluno à sociedade. Os olhares parecem não demonstrar qualquer esperança quanto à eficiência da transformação que a pessoa poderá ter a partir de um processo de educação formal. Os estigmas dos sujeitos parecem desconhecer a função social da escola.

O terceiro conceito privilegiado foi o de educação inclusiva. Para os depoentes é preciso que a política educacional seja mais real e menos idealista. Em entrevistas pode-se constatar que:

\begin{tabular}{|c|r|}
\hline $\begin{array}{l}\text { Número de } \\
\text { Professores }\end{array}$ & Categoria de Resposta dosProfessores da Escola Especial \\
\hline 04 & $\begin{array}{r}\text { Educação que garante ao deficiente o direito a cidadania. } \\
02\end{array}$ \\
$\begin{array}{r}\text { Educação que possibilita ao deficiente participar, junto aos normais,da } \\
\text { vida em sociedade de forma mais ampliada. }\end{array}$ \\
\hline
\end{tabular}

Quadro 5 - Concepção de Educação Inclusiva

O conceito de educação inclusiva apresentado tanto pelos depoentes de escola especial como pelos da escola inclusiva pressupõe que a garantia do direi- 
to à educação da pessoa com necessidade educacional especial se dá em cumprimento a documentos oficiais como a Declaração de Salamanca, a atual Lei de Diretrizes e Bases da Educação Nacional e o Estatuto da Criança e Adolescente que asseguram educação para todos. Outro aspecto observado foi o uso da terminologia deficiente ainda agregado a concepção médica, principalmente no que se refere aos depoimentos onde a terminologia anormal e deficiente foi utilizada como sinônimo. O quadro abaixo permite visualizar a compatibilidade dos olhares dos professores entrevistados.

\begin{tabular}{|c|r|}
\hline $\begin{array}{l}\text { Número de } \\
\text { Professores }\end{array}$ & $\begin{array}{r}\text { Categoria de Resposta dosProfessores da Escola Inclusiva } \\
\hline 18\end{array}$ \\
02 & $\begin{array}{r}\text { Educação que inclui o deficiente dando a ele condições de } \\
\text { dignidadeno processo de aprendizagem. } \\
06\end{array}$ \\
Educação que favorece o gozo do direito de ser cidadão. \\
Educação que inclui o deficiente em escolas de normais.
\end{tabular}

Quadro 6 - Concepção de Educação Inclusiva

\section{CONSIDERAÇÕES FINAIS}

Esse estudo foi de extrema relevância tanto para nossa formação pessoal como profissional, pois contribuiu para alargar o nosso olhar sobre a forma como os conceitos de educação, educação especial e inclusiva podem ser apropriados e representados no cotidiano educacional e o quanto influenciam no saber-fazer do educador.

Entender que a construção de qualquer proposta de educação inclusiva parte da construção coletiva desses conceitos permitirá ao professor acreditar que os espaços inclusivos possibilitarão a superação de desafios enfrentados pela pessoa com necessidades especiais nos contextos de exclusão social.

Segundo as observações realizadas, nas instituições de ensino selecionadas neste estudo, pode-se constatar que a inclusão é uma preocupação de toda comunidade escolar. No entanto, o mesmo coletivo percebe-se limitado tendo em vista que a inclusão implica o cumprimento de direitos humanos e cívicos. 


\section{REFERÊNCIAS}

BRACHT, Valter. Educação física: a busca da autonomia pedagógica. Revista da Educação Física, Maringá, v.1, n. 0, p. 28-33, 1989.

BRASIL. Lei n. 9.394, de 20 de dezembro de 1996. Estabelece as diretrizes e bases da educação nacional. Brasília, 1996. Disponível em: < http://www.planalto.gov.br/ ccivil_03/ Leis/ L9394.htm\#art92>. Acesso em: 15 set. 2007.

BRASIL. Ministério da Educação e Cultura. Centro Nacional de Educação Especial. Diretrizes básicas para ação do Centro Nacional de Educação Especial. Brasília, 1974.

BRASIL. Ministério da Educação e do Desporto. Plano nacional de educação. Brasília, 1997.

CANTARINO FILHO, Mário. A educação física no Estado Novo: história e doutrina brasileira. 1982. 217 f. Dissertação (Mestrado em Educação) - Universidade de Brasília, Brasília, 1982.

CHARTIER, Roger. A história cultural. Lisboa: DIFEL; Rio de Janeiro: Bertrand, 1990.

GHIRALDELLI JÚNIOR, Paulo. Educação física progressista. São Paulo: Editora Loyola, 1992.

GORGATTI, Márcia Greguol; COSTA, Roberto Fernandes da. Atividade física adaptada. São Paulo: Manole, 2004.

LE GOFF, Jacques. História e memória. São Paulo: Editora da Unicamp, 1984.

TRIVIÑOS, Augusto Nibaldo Silva. Introdução à pesquisa em ciências sociais: a pesquisa qualitativa em educação. São Paulo: Atlas, 1987. 


\section{ABORDAGEM MULTIDIMENSIONAL}



FAMILIA E ESCOLA: como essa parceria pode favorecer crianças com necessidades educativas especiais

Cláudia Paranbos de Jesus Portela Célia Verônica Paranhos de Jesus Almeida

\section{INTRODUÇÃO}

Não se pode deixar de reconhecer que, entre os fatores que exercem influência educativa na formação da personalidade do indivíduo, a família e a escola ocupam um lugar imprescindível e indissociável. Apesar de possuírem características e possibilidades diferenciadas, com bastante frequência essas instituições se superpõem e se complementam, atingindo ambas a conduta do indivíduo de tal modo, que não se pode abordar o desenvolvimento do indivíduo e a sua educação sem tê-las em conta.

Com base nessas ideias e tendo como enfoques a educação das pessoas com necessidades educativas especiais e a discussão sobre o paradigma inclusivo, o presente artigo versa sobre como a parceria entre pais de crianças com necessidades educativas especiais e escola pode contribuir junto ao processo educativo das mesmas. Os referenciais teóricos básicos do estudo encontram-se nos postulados da teoria sócio-histórico-cultural.

\section{A RELAÇÃO FAMÍLIA-ESCOLA: OS APORTES DA TEORIA SÓCIO- HISTÓRICO-CULTURAL}

A família configura-se como uma instituição socializadora, como célula básica da sociedade, cuja importância é decisiva no desenvolvimento do indiví- 
duo. Proprietária de uma característica não comum às outras instituições, a família possibilita a realização de vínculos filiais expressos em relações afetivas e emocionais entre seus membros, difíceis de se encontrar em outros ambientes sociais, pois o ser humano, ao nascer, já se encontra integrado numa família específica, com características próprias, pertencente a uma determinada cultura e ocupando uma posição socioeconômica definida dentro de um certo grupo cultural. Ainda mais, ele já nasce com um lugar, de certa forma, predeterminado dentro do grupo familiar.

Ressalta-se que especialistas de diversas áreas - pedagogos, psicólogos, médicos, sociólogos, entre outros - comprovam como os comportamentos familiares constituem premissas básicas no desenvolvimento da personalidade do indivíduo, a começar pela aquisição de formas simples de comportamento, que passam a formas mais complexas, como as normas e os valores, até chegar à transmissão da herança cultural própria tanto da família como da sociedade. Com isso, pode-se considerar a família como uma instância mediadora entre o indivíduo e a sociedade na qual se encontra inserido.

Para uma melhor compreensão do papel da família no desenvolvimento psíquico da criança, são fundamentais as contribuições de Lev Semionovich Vygotsky. Segundo a teoria sóciohistóricocultural, formulada por esse autor, o indivíduo se constitui como ser devido aos processos de maturação orgânica e, principalmente, através de suas interações sociais, a partir das trocas que estabelece com seus semelhantes, as quais dão origem a suas formações psíquicas. Assim, para esse teórico, as funções psíquicas superiores do ser humano estão vinculadas ao aprendizado e à apropriação do legado cultural de seu grupo.

Segundo essa teoria, o referido patrimônio cultural, nas suas formas material e simbólica, consiste num conjunto de valores e conhecimentos que a humanidade construiu no decorrer de sua história. Entretanto, para que o indivíduo possa se apropriar desse conhecimento, necessária se faz a mediação com os outros, especialmente com aqueles mais experientes do seu grupo cultural. Nesse contexto, o conhecimento, antes de existir como próprio, existe como conhecimento compartilhado. A relação da criança com os objetos do conhecimento está mediatizada pelas relações que estabelece com os adultos ou com outras crianças; só em seguida é que essas relações estarão mediatizadas pelos conhecimentos próprios, ou seja, pelas representações mentais que se estruturam e reestruturam durante o processo de apropriação da cultura.

Assim, para que essa apropriação se efetive, é preciso que haja a internalização, o aprendizado, o qual implica a transformação dos processos 
externos ou interpsicológicos (consolidados nas atividades entre as pessoas) num processo intrapsicológico (a atividade é reconstruída interna e individualmente). Nesse sentido, o processo de desenvolvimento do indivíduo, originado por sua inclusão num grupo cultural específico, ocorre de "fora para dentro" como assinala Oliveira (1998). Ou seja, a princípio, o ser humano realiza ações de ordem externa, que serão analisadas pelas pessoas com quem convive, segundo os significados estabelecidos culturalmente. A partir dessa análise, será possibilitado ao sujeito conferir significados às suas ações e, paralelamente, desenvolver processos psicológicos internos, que podem ser interpretados por ele mesmo a partir dos instrumentos colocados pelo grupo social do qual participa e compreendidos através dos códigos partilhados pelos membros desse grupo. Dessa maneira, para Vygotsky, o desenvolvimento pleno do ser humano depende do aprendizado que realiza num certo grupo cultural, através da interação que estabelece com os outros indivíduos da sua espécie. Para esse autor, é o aprendizado que possibilita e movimenta o processo de desenvolvimento, isto é, o aprendizado é o aspecto necessário e universal, uma espécie de garantia do desenvolvimento das características psicológicas especificamente humanas e culturalmente organizadas.

Nessa perspectiva, Vygotsky faz referência a dois planos de desenvolvimento: o primeiro, que diz respeito às conquistas já adquiridas, ou seja, o nível de desenvolvimento real, e o segundo, que denomina nível de desenvolvimento potencial ou proximal, o qual se refere às capacidades a serem construídas. $\mathrm{O}$ nível de desenvolvimento real pode ser entendido como capacidade de realizar tarefas independentemente. Esse nível de desenvolvimento real caracteriza o desenvolvimento da criança de maneira retrospectiva, referindo-se a etapas já alcançadas por ela. " $[\ldots .$.$] As funções psicológicas que fazem parte do nível de$ desenvolvimento real da criança em determinado momento de sua vida são aquelas já bem estabelecidas naquele momento. São resultados de processos de desenvolvimento já completados, já consolidados." (OLIVEIRA, 1998, p. 59). O nível de desenvolvimento potencial também se refere ao que o indivíduo já é capaz de fazer mediante a ajuda de outras pessoas, que podem ser adultos ou companheiros mais capazes. Nesse aspecto, denomina-se Zona de Desenvolvimento Proximal (ZDP), "la distancia entre el nivel de desarrollo actual, según determinado por la solución independiente de problemas, y el nivel de desarrollo potencial, según determinado por medio de la solución de problemas bajo la orientación de un adulto o en colaboración con pares más." (VYGOTSKY, 1978 apud RODRIGUEZ, 1997, p. 56). 
O desenvolvimento da criança passa a ser visto de maneira prospectiva, visto que a zona de desenvolvimento potencial define as funções que estão em processo de maturação, presentes em estado embrionário.

Essa análise revela a importância básica da relação social no desenvolvimento psíquico, como a fonte de onde a criança recebe o material para a formação das qualidades psíquicas de sua personalidade. É nessa relação mediada pelo adulto que a criança se apropria do patrimônio cultural acumulado pela sua sociedade. Essa apropriação se realiza através da atividade da criança na relação com os objetos e fenômenos do mundo que a rodeia, nas relações práticas e verbais com as pessoas e nas atividades conjuntas que realiza com elas. Dessa forma, as qualidades psíquicas, nas quais se apoia a atividade da criança, não surgem, mas se formam durante o processo de socialização e educação.

É válido ressaltar que os postulados vygotskyanos oferecem aspectos imprescindíveis para o desenvolvimento de uma educação baseada nas possibilidades de aprendizagem e também no desenvolvimento das potencialidades das pessoas possuidoras de necessidades especiais.

Partindo da ideia de oposição à concepção biologizante do desenvolvimento, Vygotsky postulou uma orientação eminentemente otimista e positiva com relação à deficiência, afirmando que, tanto no processo de formação e desenvolvimento da personalidade das crianças "normais" como no de crianças com deficiência, atuam as mesmas leis gerais.

La peculiaridad positiva del niño con deficiencias también se origina, en primer lugar, no porque en él desaparece unas o otras funciones observadas en un niño normal, sino porque esta desaparición de las funciones hace que surjan nuevas formaciones que representan, en su unidad, una reacción de la personalidad ante la deficiencia, la compensación en el proceso de desarrollo. (VYGOTSKY, 1989, p. 7).

Nessa perspectiva, fica evidenciada a necessidade de uma pedagogia que possibilite o desenvolvimento das potencialidades das crianças, tornando-as capazes de assumirem plenamente seu papel ativo e transformador no grupo social do qual fazem parte. Vygotsky considera o defeito como uma limitação, cuja influência é dupla e contraditória. Primeiro, porque o defeito abate o organismo e prejudica sua atividade. Segundo, porque, além de dificultar e alterar a atividade do organismo, serve como estímulo para o desenvolvimento de outras funções e o provoca a realizar uma ação intensificada para poder compensar a 
deficiência e, assim, vencer as dificuldades. Tendo como base esse pressuposto é que a defectologia contemporânea estabelece como postulado central que qualquer defeito origina estímulos para a formação da compensação. Nesse sentido, Vygotsky (1987, p. 7) ressalta que:

[...] si un niño ciego o sordo alcanza en el desarrollo lo mismo que un niño normal, entonces los niños con deficiencia lo alcanzan de un modo diferente, por otra vía, con otros medios y para el pedagogo es muy importante conocer la peculiaridad de la vía por la cual él debe conducir al niño.

A compensação do defeito funciona como uma reação da personalidade diante da deficiência, que dá início a novos processos de desenvolvimento, substitui, superestrutura e equilibra as funções psíquicas.

Como afirma Vygotsky (1987), não se pode negar que a cegueira ou a surdez são deficiências de ordem biológica; entretanto o educador tem de enfrentar não somente esse aspecto, como também as suas consequências sociais. Assim, o conhecimento sobre a estrutura do defeito deve se constituir no aspecto norteador da prática pedagógica com os alunos com necessidades educativas especiais.

Compreende-se, portanto, que a família e a escola desempenham um papel muito importante para o desenvolvimento integral da criança, sendo que, nesse sistema de influências, sob o qual transcorre a formação da criança, a família ocupa, para Vygotsky, um lugar privilegiado, por transmitir ao indivíduo a herança cultural própria da família e da sociedade, bem como os elementos essenciais para a sua formação. Dessa forma, a família se constitui num grupo social primário, no qual se realiza a chamada socialização primária, que consiste na apreensão dos papéis sociais, na formação da identidade social e pessoal do indivíduo, como também na imagem que a pessoa tem de si mesma. Posteriormente, então, em contato com o grupo social mais amplo, através do processo de socialização secundária, é que a criança deverá fazer novos ajustes visando à sua adaptação. Nesse aspecto, o tipo de inserção social que a pessoa terá dependerá do que ocorreu durante seus anos formativos, no seu grupo social de origem.

Nesse aspecto, apesar de a família não ser o único espaço onde se pode tratar a questão da socialização, constitui-se, sem dúvida, num âmbito privilegiado, visto que ela tende a ser o primeiro grupo responsável pela tarefa socializadora. A família se institui, pois, como uma das mediações entre o ho- 
mem e a sociedade. Sob esse ângulo, ela não só interioriza aspectos ideológicos dominantes na sociedade, como projeta, ainda em outros grupos, os modelos de relação criados e recriados dentro do próprio grupo.

Diante de tais considerações, não se pode, pois, entender a criança com necessidades educativas especiais em sua integridade, sem se considerar o contexto familiar de que faz parte. Especialmente para os deficientes, cujos horizontes socioafetivos tendem a ser mais reservados, a família representa a primeira e mais importante instituição social, pois é com os membros de sua família que eles mantêm as relações pessoais mais próximas e importantes, em muitos casos as únicas.

\section{FAMÍLIA E ESCOLA: RAZÕES QUE JUSTIFICAM O ESTREITAMENTO DE LAÇOS}

A educação familiar dos filhos, sobretudo daqueles que apresentam necessidades educativas especiais, representa um requisito social decisivo para a sua formação escolar, e, ao longo de todo o período escolar, é uma condição essencial tanto para o desenvolvimento da personalidade como para a educação por parte da escola. Tem-se constatado que, quando os pais participam ativamente da educação dos filhos, esses tendem a render mais na escola, e seus progressos são maiores. Segundo mostram os dados do Sistema de Avaliação da Educação Básica (Saeb) de 1999, nas escolas que contam com a participação dos pais, por meio de trocas de informações com os professores e os diretores, os alunos tendem a aprender mais e melhor (Quadro 1).

\begin{tabular}{|c|c|c|}
\hline PORTUGUÊS & $\begin{array}{c}\text { Nota média / pais não } \\
\text { conhecem o professor }\end{array}$ & $\begin{array}{c}\text { Nota média/ pais } \\
\text { conhecem o professor }\end{array}$ \\
\hline $4^{\text {a }}$ série - ens. fund. & 165,24 & 174,14 \\
$8^{\mathrm{a}}$ série - ens. fund. & 230,01 & 241,91 \\
$3^{\mathrm{a}}$ série - ens. médio & 265,9 & 277,24 \\
\hline MATEMÁTICA & Nota média / pais não & Nota média/ pais \\
& conhecem o professor & conhecem o professor \\
\hline $4^{\mathrm{a}}$ série - ens. fund. & 178,11 & 184,80 \\
$8^{\mathrm{a}}$ série - ens. fund. & 243,38 & 257,06 \\
$3^{\mathrm{a}}$ série - ens. médio & 281,29 & 294,03 \\
\hline
\end{tabular}

Quadro 1 - Relação Pais - Escola X Desempenho Escolar dos Filhos Fonte: JORNAL..., 2001a. 
Os dados acima constatam que, na disciplina de português, na $4^{\mathrm{a}}$ série do ensino fundamental, o diferencial em termos de desempenho escolar dos alunos, cujos pais não conhecem o professor, para os pais que o conhecem é de 8,90 pontos, sendo esses dados elevados na 8 a série do ensino fundamental, em que a diferença fica em 11,9 pontos, e apresentando-se, na $3^{\text {a }}$ série do ensino médio, com o valor de 11,34 pontos. Com relação à disciplina matemática, percebe-se situação semelhante à da disciplina português quanto à diferença nas taxas de desempenho escolar dos alunos. $\mathrm{Na} 4$ a série do ensino fundamental, o diferencial dos pais que não conhecem o professor para os pais que o conhecem está em torno de 6,69 pontos; na $8^{\text {a }}$ série do ensino fundamental, esse valor atinge 13,68 pontos e, na $3^{\text {a }}$ série do ensino médio, fica com uma taxa representativa de 12,74 pontos. Infere-se, a partir dessas informações, a relevância que tem a família em termos qualitativos no desempenho escolar do aluno junto à escola, ao mesmo tempo em que se constata que a influência exercida pelos pais sobre o processo de escolarização dos filhos se atenua com o tempo.

Justificando a importância da relação família-escola, o professor Francisco Soares ${ }^{1}$, a partir de dados estatísticos sobre o desempenho na avaliação dos alunos, revela que o envolvimento dos pais com a escola dos filhos propicia um aumento de até 14 pontos na nota média do aluno nas provas do Sistema de Avaliação da Educação Básica (Saeb). Com isso, observou que há um diferencial de desempenho do estudante associado ao envolvimento dos pais com a escola. Assim, compreende-se que a escola:

[...] pela função que a sociedade lhe concede, pelos recursos que possui, pela preparação científica de seu pessoal, entre outros, está em condições de exercer uma influência muito poderosa, porém necessita de uma relação estreita com a família para que seja mais efetiva. (PEREA, 1997, p. 10).

A escola e a família, portanto, devem estreitar os laços, especialmente quando se trata de crianças com necessidades educativas especiais (NEE). Esse estreitamento está ligado ao fato de que a ação educativa sistematizada não deve se direcionar ao indivíduo à margem de suas necessidades sociais, econômicas e culturais, dos problemas concretos em que se encontra inserido, mas sim a um sujeito, constituído de realidade material e simbólica.

\footnotetext{
${ }^{1}$ Coordenador do Grupo de Avaliação e Medidas Educacionais da Universidade Federal de Minas Gerais (Game/UFMG).
} 
Frequentemente, essa relação tem sido caracterizada por laços de autoridade por parte da instituição escolar, assemelhando-se a laços de autoritarismo, devido ao lugar que a escola ocupa no imaginário da instituição familiar. Todavia, no tocante às pessoas com NEE, com a criação e oficialização da Declaração Mundial de Educação para Todos o quadro dessas relações tem sido modificado, ao menos no que diz respeito ao nível das recomendações. A razão está no fato de a proposta ter trazido consigo o paradigma da inclusão ${ }^{2}$ e, junto a esse, a importância de se analisarem os fatos educativos através de um ponto de vista múltiplo, que considere todas as dimensões implicadas nos referidos fenômenos. Dessa forma, a família conquista um outro papel nesses processos: não apenas como fonte de origem do alunado, mas também como a provedora das primeiras formas de relações educativas.

Numa análise mais detalhada sobre o papel da família, constata-se que ela se constitui no "primeiro berço educacional do ser humano" (SANTOS, 1999, p. 40), possuindo algumas obrigações convencionalmente estabelecidas nas sociedades a que pertencem. $\mathrm{Na}$ sociedade ocidental brasileira, alguns de seus papéis são expostos em documentos legais. A título de exemplo, tem-se o Estatuto da Criança e do Adolescente e a Constituição Federal. Em ambos documentos, verificam-se aspectos comuns quanto ao papel da família no desenvolvimento dos filhos:

- Garantir a escolarização;

- Garantir uma criação voltada para a cidadania e uma vida digna;

- Garantir proteção, carinho e afeto.

Trata-se, então, de buscar fazer com que a família se perceba como participante do processo educacional, uma vez que ela pode contribuir com aspectos fundamentais durante o tempo que a criança passa sob sua influência, sem, no entanto, ter a pretensão de substituir o lugar da escola. É preciso rever a concepção que coloca a escola em posição de cobrança, e a família em posição de culpada, ou cobrada. Assim, a família funciona como um elemento estratégico no processo de escolarização dos alunos que não apresentam um resultado espe-

\footnotetext{
2 "[...] processo pelo qual a sociedade se adapta para poder incluir, em seus sistemas sociais gerais, pessoas com necessidades especiais, simultaneamente, estas se preparam para assumir seus papéis na sociedade." (SASSAKI, 1997, p. 36).
} 
rado. Nas recomendações internacionais, essas necessidades ficam expressas de forma muito evidente, como no artigo 58 da Declaração de Salamanca (1994):

Os Ministérios da Educação e as escolas não devem ser os únicos a perseguir o objetivo de dispensar o ensino a crianças com necessidades educativas especiais. Isso exige também a cooperação das famílias e a mobilização da comunidade [...].

Isso ainda é ratificado no artigo 61, em que o mesmo documento estabelece que:

Deverão ser estreitadas as relações de cooperação e de apoio entre administradores das escolas, professores e pais, fazendo com que estes últimos participem na tomada de decisões em atividades educativas no lar e na escola $[\ldots .$.$] e na supervisão e no apoio$ da aprendizagem dos filhos.

A escola, entretanto, vê-se passando por uma transformação histórica com consequências diretas na revisão de seu papel. Diante do exposto, ficam claras a abrangência e a necessidade da definição do papel da escola e da família, bem como da necessidade de parceria entre elas. Ressalta-se, também, que, no âmbito das relações entre família e escola, torna-se fundamental assumir um compromisso de reciprocidade entre elas. De um lado, encontra-se a família, com sua vivência e sabedoria prática sobre seus filhos. Do outro, a instituição escolar, com sua vivência e sabedoria a respeito dos seus alunos. Todavia é preciso entender que esses mesmos alunos são também os filhos, e que os filhos são os alunos. Dito de outra maneira, deve-se às duas instituições básicas das sociedades o movimento de aproximação, num plano mais horizontal, de distribuição mais igualitária de responsabilidades. Esse mesmo pressuposto, está evidenciado no artigo 58 da Declaração de Salamanca (1994):

As autoridades responsáveis pela educação aos níveis nacional, estadual e municipal têm a obrigação prioritária de proporcionar educação básica para todos. Não se pode, todavia, esperar que elas supram a totalidade dos requisitos humanos, financeiros e organizacionais necessários a esta tarefa. Novas e crescentes articulações e alianças serão necessárias em todos os níveis [...]. É particularmente importante reconhecer o papel vital dos 
educadores e das famílias [...]. Quando nos referimos a um enfoque abrangente e a um compromisso renovado, incluímos as alianças como parte fundamental.

Assim, para Santos (1999, p. 43):

As famílias precisam se aproximar da escola não apenas comparecendo a reuniões de pais ou participando de Conselhos EscolaComunidade através de representantes, mas é preciso que ela se inteire mais diretamente no processo educacional acadêmico dos seus filhos, ajudando-os a aprender [...].

A escola, por sua vez, precisa abrir suas portas às famílias, de fato e de direito, não alimentando uma relação hierárquica e autoritária ou assumindo papel de juiz ou cobrador da família, mas, sobretudo, ampliando o espaço de participação, respeitando o desejo desta e auxiliando-a a se informar para crescer numa relação mais igualitária. Pois, só com o estabelecimento de uma relação nesse nível é que as propostas educacionais, especificamente aquelas voltadas para as pessoas com necessidades educativas especiais, relativas à formação de cidadãos, poderão se concretizar.

Nesse sentido, a partir do reconhecimento do poder público brasileiro sobre a importância da participação da família no desempenho escolar do filho, o Ministério da Educação e Cultura (MEC) lançou uma campanha de mobilização nacional, com o objetivo de sensibilizar e conscientizar a sociedade em geral para o valor da integração entre pais e escola. Intitulada como o Dia Nacional da Família na Escola, a campanha vale-se da experiência que comprova que o interesse dos pais pelo sucesso dos filhos é fator relevante para a melhoria do rendimento do aluno.

Também uma pesquisa do IBGE, realizada em dezembro/2000 com duas mil pessoas em todo o País, mostra que os pais são conscientes da necessidade de integração entre família e professores. Desse quantitativo, 97\% dos entrevistados (com filhos em escolas públicas) disseram ser a favor de visitas à escola com mais frequência. Outros $93 \%$ afirmaram que é importante acompanhar o desenvolvimento do filho na escola, e que os pais deveriam ter, pelo menos, oito reuniões anuais com os professores (JORNAL..., 2001b).

Dessa forma, constata-se que a parceria família-escola é necessária para o desenvolvimento integral dos educandos, especificamente para aqueles que apresentam NEE, muito embora seja necessário destacar que essa não se afirma 
espontaneamente com a presença da criança na escola, tampouco com as relações formais entre pais e professores. Ao contrário do que se pensa, essa relação perpassa um complicado e contraditório processo, cujo desenvolvimento depende, sobretudo, do empenho que realizem pais e professores.

\section{REFERÊNCIAS}

BRASIL. Constituição (1998). Constituição da República Federativa do Brasil. Brasília, DF: Senado, 1988.

BRASIL. Ministério da Ação Social. Coordenadoria Nacional Para Pessoa Portadora de Deficiência. Declaração de Salamanca e linha de ação sobre necessidades educativas especiais. Brasília, DF, 1994. 54 p.

. Centro Brasileiro para Infância e Adolescência. Estatuto da criança e do adolescente. Brasília, 1990.

DECLARAÇÃO mundial sobre educação para todos: satisfação das necessidades básicas de aprendizagem. Disponível em: < http://www.unesco.org.br/publicacoes/copy_of_pdf/ decjomtien $>$. Acesso em: 30 maio 2008.

JORNAL do MEC. Brasília, v. 9, n. 9, abr. 2001a.

JORNAL do MEC. Brasília, v. 9, n. 11, jun./jul. 2001b.

OLIVEIRA, M. K. Vygotsky: aprendizado e desenvolvimento: um processo sócio-histórico. São Paulo: Scipione, 1998.

PEREA, T. de J. B. Propuesta metodológica para lo trabajo de los educadores com la familia. 1997. 66 f. Tesis (Maestria en Educación) - Instituto Superior Pedagógico Enrique José Varona, Havana. 1997.

RODRIGUEZ, M. C. R. B. Educación especial: raziones, vision actual y desafios. La Habana: Editorial Pueblo y Educación, 1997.

SANTOS, M. P. A inclusão e as relações entre a família e a escola. Revista INES, p. 40-43, jun. 1999.

STAINBACK, S.; STAINBACK, W. Inclusão: um guia para educadores. Tradução de Magda França Lopes. Porto alegre: Artes Medicas Sul, 1999.

VIGOTSKI, L. S. Fundamentos de defectología. Tradución de Lic. Ma. Del Carmen P. Fernandez. Habana: Editorial Pueblo y Educación, 1989. t. 5.

História de las funciones psiquicas superiores. Havana: Científico-Técnica,

1987. 



\title{
ESTRATÉGIA DE SAÚDE DA FAMÍLIA NO PROCESSO DE INCLUSÃO: reinserção do escolar pós-hospitalizado
}

\author{
Jamine Barros Oliveira \\ Maria Celeste Ramos da Silva \\ Nayara Alves de Sousa
}

\section{INTRODUÇÃO}

A atenção à saúde como responsabilidade do Estado é expressa na Constituição de 1988, em seu capítulo VIII, da Ordem Social. Na seção II, referente à Saúde define no art. 196 que a "saúde é direito de todos e dever do Estado, garantindo mediante políticas sociais e econômicas que visem à redução do risco de doença e de outros agravos e ao acesso universal e igualitário às ações e serviços para sua promoção, proteção e recuperação." O art. 198 dispõe sobre a organização do SUS, referindo que as "ações e serviços públicos de saúde integram uma rede regionalizada e hierarquizada, e constituem um sistema único, organizado de acordo com as seguintes diretrizes": I. Descentralização, com direção única em cada esfera de governo; II. Atendimento integral, com prioridade para as atividades preventivas, sem prejuízo dos serviços assistenciais; e III. Participação da comunidade.

Conforme se observa no exposto na Constituição, nota-se claramente a concepção de que o Sistema Único de Saúde (SUS) surgia com uma missão: voltar-se contra o modelo médico-assistencialista, pautado num modelo voltado às necessidades da população, em vista ao resgate do compromisso do Estado no desenvolvimento do bem-estar social, especialmente da coletividade (BRASIL, 1988). 
Portanto, como pressupostos da lei nascem três princípios que se complementam em suas especificidades: universalidade, equidade e integralidade. Historicamente, quem tinha direito aos serviços de saúde eram os trabalhadores segurados pelo Instituto Nacional de Previdência Social (INPS) e depois Instituto Nacional Assistência Médica Nacional (INAMPS). Com a implantação do SUS este direito passou a ser direito de todos os cidadãos brasileiros, independente de sexo, raça, renda, ocupação ou outras características sociais ou pessoais, originando o princípio da universalidade. Com o objetivo de reduzir as desigualdades surge o princípio da equidade, não como sinônimo de igualdade, uma vez que considera as diferenças, e trata com desigualdade os desiguais, mas considerando as diferentes necessidades de cada pessoa, de modo a investir mais onde a carência é maior. Trata-se de um princípio de justiça social. E por fim, o princípio da integralidade que considera a pessoa como um todo, de forma a garantir acesso do usuário ao serviço de menor ao de maior complexidade. Para tanto, faz-se necessário a articulação da saúde com outras políticas públicas, como educação, transporte, por exemplo, a fim de garantir a intersetorialidade das ações na busca da resolutividade e melhoria da qualidade de vida dos indivíduos.

Este artigo propõe-se a discutir a estratégia de saúde da família como fator integralizador de ações inclusivas entre a escola regular/famílias na reinserção de crianças, adolescentes e jovens que passaram por algum atendimento médico-hospitalar (atendimento clínico, hospitalização, reabilitação, manutenção terapêutica, pós-operatório, entre outros).

\section{ESTRATÉGIA DE SAÚDE DA FAMÍLIA (ESF): NOVO MODELO DE REORIENTAÇÃO DE ATENÇÃO À SAÚDE}

Programa concebido pelo Ministério da Saúde (MS) em 1994, como instrumento de reorganização dos serviços de saúde, serve como eixo estruturante da atenção básica à saúde. Preconiza como equipe mínima para funcionamento 01 médico, 01 enfermeiro, 02 auxiliares de enfermagem e 06 agentes comunitários de saúde. Cada equipe de saúde da família é responsável por uma população de até 4.000 pessoas, distribuídas de acordo com o Plano de Territorialização Municipal, elaborado e definido por cada município, constituindo a área de cobertura a área adstrita à unidade. As particularidades da comunidade passam a ser de conhecimento da equipe e da gestão municipal, o que facilita o processo de planejamento das ações de saúde, tornando-os corresponsáveis pelo cuidado 
à saúde. Para tanto, o agente comunitário de saúde exerce papel preponderante no sentido de servir como elo entre a comunidade e a equipe de saúde, uma vez que em visitas periódicas cadastram as famílias, notificando em seu instrumento de coleta de informações a presença de diabéticos, hipertensos, deficientes físicos ou mentais, gestantes, dentre outras informações pertinentes relacionadas a cada família.

Uma vez definida a parcela da comunidade a ser atendida pela equipe da unidade esta se responsabilizará em garantir o acesso aos serviços de saúde, visando à consolidação dos princípios norteadores do SUS. É, portanto, a porta de entrada do sistema de saúde, tendo em vista a relação direta com a comunidade.

Para que a estratégia se consolide, é necessária a reorientação das práticas de saúde, bem como a renovação dos vínculos de compromisso e de corresponsabilidade entre os serviços e a população, além da participação de outros setores, a exemplo da educação, transporte e cultura.

Conforme as Diretrizes da Educação para Saúde descritas pelo Ministério da Saúde, na abordagem retratada por Gazzinelli e outros (2005, p. 201) a Educação em Saúde seria "uma atividade planejada que objetiva criar condições para produzir as mudanças de comportamento desejadas em relação à saúde”, nesse sentido, entende-se que, a partir desse prossuposto, a Educação em Saúde tem como intenção nítida reforçar padrões de saúde concebidos pelo governo para a população. Dessa forma, pensar na inclusão e/ou reinserção de crianças, adolescentes e jovens que apresentam comprometimentos em relação à sua escolarização por consequência de afastamento escolar por motivo de atenção a saúde como o de hospitalização, também faz parte dos objetivos da estratégia de saúde da família.

\section{INCLUSÃO: UM NOVO OLHAR ÀS DIFERENÇAS}

De maneira significativa o Brasil tem criado dispositivos legais (decretos e portarias) que garantem a inclusão escolar dos portadores de necessidades educativas especiais (os deficientes, por exemplo), em todos os níveis e modalidades de ensino, além de direcionar programas e políticas educacionais e de saúde como as de reabilitação, garantindo à efetivação destas políticas os recursos necessários.

Sassaki (2002) ao retratar o movimento da inclusão, diz que este começou de maneira incipiente na segunda metade dos anos 1980, tanto nos países desenvolvidos, quanto nos países em desenvolvimento. Toma grande impulso 
na década de 1990 e vai se desenvolver fortemente nos primeiros 10 anos do século XX envolvendo todos os países.

Considerando, portanto que, tanto os alunos que não apresentam visivelmente uma condição de deficiência, quanto outros, enquadrados na condição especial, como as crianças, adolescentes e jovens que necessitam de hospitalização ou são portadores de doenças crônicas, precisam de atenção e acolhimento ao serem (re)integrados na sociedade e na escola.

A educação é um direito de todos independente do quadro clínico, físico ou psicológico do paciente. Deve-se ter uma visão humanística de atenção, visando às necessidades integrais do educando, aqui retratadas como crianças, adolescentes e jovens, sejam elas físicas, psíquicas ou sociais. Como questão social, a prática pedagógica não deve estar restrita as escolas, mas a todas as práticas educativas de uma sociedade, assegurando a continuidade dos conteúdos escolares, ademais garantir a possibilidade de um retorno sem prejuízos a escola de origem após a alta hospitalar.

A orientação de práticas educativas, não está restrita ao espaço formal da escola, ela existe em toda parte, muito mais que na escola, pois faz parte da ação do homem. Nesse sentido, Brandão (1984, p. 47) sinaliza que a prática educativa ou educacional, "é o resultado da ação de todo o meio sociocultural sobre os seus participantes. É o exercício de viver e conviver o que educa."

Assim, as dificuldades e os impedimentos colocados pela sociedade, e muitas vezes pela escola, dificultam a ressocialização dessas crianças, adolescentes e jovens a atividades normais de maneira importante, quando são indicados para afastarem-se, por medo, discriminação, ou até mesmo desconhecimento de suas reais necessidades.

Um número crescente de alunos previamente excluídos está sendo integrado ou reintegrado ao ensino regular. Entretanto, esses alunos precisam mais do que ser colocados nas escolas com todos os direitos, sendo valorizados e respeitados como quaisquer outros mantidos regularmente em suas classes e séries correspondentes. O que já representa um salto positivo para se pensar que o processo inclusivo como uma necessidade para todos, não apenas para os póshospitalizados.

A escola deve apresentar qualidade de ensino para todos independente da situação ora apresentada, tendo organização de propostas pedagógicas eficazes e flexibilizadoras, relacionadas às necessidades de cada aluno, seja ele dito normal ou portador de necessidades educativas especiais. 
A escola inclusiva é o processo de adaptação da escola, dos profissionais, dos currículos, dos procedimentos, das metodologias, avaliações, interações espaço, tempo, critérios e programas para inclusão de todos em todos os seus graus. (ROSS, 2004, p. 31).

A educação inclusiva amplia a participação de todos os estudantes no ensino regular. Ela está atenta para a diversidade inerente à espécie humana, busca perceber e atender as necessidades educativas especiais de todos de forma a promover a aprendizagem e o desenvolvimento pessoal.

Após a alta hospitalar, crianças, adolescentes e jovens precisam retornar a sua escola de origem. A partir daí surge uma nova realidade, que propõe novos desafios aos educadores, possibilitando a construção de novos conhecimentos, tendo em vista a melhor recuperação e socialização da criança no espaço escolar, ao permitir a continuidade de suas aprendizagens evitando assim, o fracasso em sua vida acadêmica.

A orientação de estratégias didático-metodológicas que aperfeiçoem a adaptação escolar e/ou o processo de ensino-aprendizagem quando do retorno ou primeiro ingresso deste paciente à escola pode ser relativa tanto à implementação de recursos e medidas alternativas, quanto a condutas e posturas do professor daquela escola, mais adequadas em relação ao aluno, portador de deficiência, e demais alunos da turma. (BARROS, 1999, p. 90).

Destacamos, portanto que não apenas os alunos com deficiência devem relacionar-se diretamente com o saber, também aqueles que apresentam outras necessidades educativas especiais importantes como os pós-hospitalizados, os alunos que necessitam de atenção escolar domiciliar, os lesados medulares, os alunos com doenças crônicas e outros necessitam de atenção em suas aprendizagens. Assim, fica evidente que uma relação de igualdade com o professor, permitiria que este fosse capaz de adquirir uma consciência crítica de si, do outro e do mundo, estabelecendo equilíbrio na sua autoestima, e, portanto, buscando sempre novos objetivos e horizontes. Dessa forma, defendemos como indica Marques (1999, p. 47):

que construir conhecimentos em nossas salas de aula significa tecer relações entre os saberes provindos das mais diversas instâncias de nosso viver. Alunos e professores são portadores de saberes que se interagem, se completam. 
As dificuldades dessas crianças, desses adolescentes e jovens devem ser superadas, evitando-se discriminação, descomprometimento e irresponsabilidades por parte daqueles que compõem o quadro integrativo tanto da escola quanto da família. A sociedade de modo geral precisa rever suas práticas; precisa educar-se. Esses alunos devem e precisam ser re-inseridos, incluídos no meio educacional, frequentando classes e ambientes comuns obtendo apoios diversificados.

Ross (2004, p. 32), postula o processo de inclusão como aquele "pelo qual pessoas com ou sem deficiência, profissionais ou não e instituições buscam, em parceria, resolver problemas, tomar decisões e promover transformações nos serviços, nas leis e na realidade."

São muitos os benefícios das ações inclusivas para todos os envolvidos com a escola. A facilitação programática da inclusão na organização e nos processos escolares é um fator primordial e necessário para o sucesso na escolarização do alunado.

A educação inclusiva enfatiza uma nova realidade para a tradicional educação especial, onde estes alunos ganharão mais oportunidades marcadas pela oferta de ajuda, visando uma conquista da autonomia e da independência tendo uma melhor qualidade de vida educacional e social.

\section{SAÚDE-EDUCAÇÃO: UMA INTEGRAÇÃO NECESSÁRIA}

Ao entender a estratégia de saúde da família, pode-se detectar seu papel enquanto agente integralizador de ações que visem garantir ao indivíduo bemestar, qualidade de vida e resolutividade em questões que o tiram da sua "normalidade", ou seja, é responsável por integrar a criança, adolescente, jovem, adulto e idoso à sociedade, incluindo-os na escola, no lazer, na cultura, entre outros, uma vez que se entende a saúde não como mera ausência de doença.

Enquanto porta de entrada do sistema de saúde a atenção básica, por meio da estratégia de saúde da família, tem como assistir a família, uma vez determinada uma área de cobertura, detectando os mais vulneráveis e suscetíveis a doenças e acompanhando os que foram hospitalizados, por causas externas ou não.

É função da equipe detectar crianças e jovens que, por determinado motivo, necessitaram de hospitalização, ausentando-se do convívio familiar e social, principalmente da escola, local de aprender a interpretar o mundo para poder transformá-lo, a partir do convívio com o próximo e com o meio. 
A inclusão e reinserção de crianças, adolescentes e jovens após alta hospitalar deve ser também uma questão de preocupação norteadora das ações da unidade de saúde da família, ou seja, a equipe deve estar atenta e apta a detectar condições que desfavoreçam o desenvolvimento cognitivo destes a fim de que os mesmos possam se tornar agentes que contribuam de maneira eficaz no processo de retorno dessas crianças, jovens e adolescentes ao ambiente escolar. Para tanto, é imprescindível uma ação intersetorial entre família - equipe de estratégia - escola e secretarias de educação, a fim de promover articulações que culminem com a garantia do direito de "todos na escola".

Diante disto, é comum verificarmos que um número significativo desta população, aqui expressa pelos alunos pós-hospitalizados, permanece afastado interrompendo um ciclo de estudo por considerar incômoda sua volta à escola, por aconselhamento da escola ou da família que desconhecem o potencial de desenvolvimento cognitivo do educando. A ausência na atenção às potencialidades do educando que necessitou de uma hospitalização gera desconforto aos profissionais de educação, pois as informações sobre, como lidar com esta situação, são pouco discutidas, ou desconhecidas por este profissional, apesar de constar informações sobre saúde em documentos oficiais como nos Parâmetros Curriculares Nacionais, que tratam desta abordagem como tema transversal e da Educação Especial, através vários documentos disponibilizados pelo Ministério da Educação e da Cultura (MEC).

Para melhor compreensão poderíamos, em outras palavras, dizer que, após a alta-hospitalar, tanto o setor de saúde através do assistente social e o agente do ESF fariam parte de uma rede integrada de comunicação e atenção para dar encaminhamento e/ou matrícula deste aluno para a escola regular, tendo o professor da classe hospitalar, como catalisador e negociador desta ação coletiva. Sendo assim, quando a escola ou o professor da escola regular não sentirem-se preparados para atender a esse aluno conforme a seus direitos e necessidades, a equipe da unidade de saúde da família os acompanharia dando-lhes suporte.

O que se observa também é a maneira pela qual se concebe o conceito de saúde, este, portanto distanciado das questões de educação, lazer e bem-estar biopsicossocial do educando. O conceito de saúde está diretamente relacionado com a cultura da população. Segundo Chiattone (1986, p. 43), esta concepção é diversificada e varia de acordo com os diferentes grupos sociais e isso demonstra "que a saúde não só tem uma dimensão social, mas quando é vinculada à qualidade de vida da sociedade, assume uma dimensão política", assim, caracteriza-se por um conjunto de ações no âmbito individual e coletivo. 
Mas, o mais recorrente é que, de maneira geral, tanto os profissionais de educação quanto as famílias tendem a entender no conceito de saúde apenas o bem-estar físico da pessoa doente, esquecendo e/ou menosprezando os aspectos mentais. Nesse sentido, a presença dos agentes comunitários de saúde, pode contribuir, conscientizando e orientado escola/família quanto ao seu papel na vida deste escolar, como também reforçar o trabalho integrado entre os setores saúde-educação.

Nesse sentido, tomar como ação política, a atenção e os cuidados com a saúde de crianças, adolescentes e jovens que necessitaram de uma intervenção terapêutica ou de um tratamento médico mais demorado, é fazer constar de fato os pressupostos norteadores da estratégia de saúde da família, tomando como base os direitos de universalidade, equidade e integralidade expressos nos princípios do SUS.

\section{PARA NÃO FINALIZAR... BREVES CONSIDERAÇÕES}

A educação por si só não deve ser a responsável pelo processo de inclusão escolar de crianças, adolescentes e jovens, após a alta hospitalar, é necessário integração com outros setores; e no que diz respeito à saúde, a estratégia de saúde da família se torna agente aliado neste processo, uma vez que ter conhecimento e acesso às famílias adstritas à sua área de cobertura possibilita o contato família-escola.

O profissional da equipe de saúde da família deve, portanto, ter uma visão holística do processo de saúde-doença, a fim de contribuir para o pleno desenvolvimento biopsicossocial de crianças, jovens e adolescentes pós-hospitalizados, como também os profissionais da educação, a fim de que as iniciativas para o processo de inclusão se dêem de maneira conjunta, intersetorial.

Interrelacionar saúde e educação permitem, portanto, não apenas uma aproximação dos profissionais de saúde e educação, mas, contudo, uma contribuição dialógica para o aperfeiçoamento das políticas públicas que servem às populações menos assistidas, e mais, gradativamente, corroboraria para diminuir as distâncias entre sucesso e fracasso escolar, colocadas na vida dessas crianças devolvendo-lhes confiança e vontade para crescer. 


\section{REFERÊNCIAS}

BARROS, A. S. A prática pedagógica em uma enfermaria pediátrica: contribuições da classe hospitalar à inclusão desse alunado. Revista Brasileira de Educação, n. 12, p. 84-93, 1999.

BRANDÃO, C. R. O que é a educação? São Paulo: Brasiliense, 1984.

BRASIL. Constituição (1998). Constituição da República Federativa do Brasil. Brasília, DF: Senado, 1988.

. MINISTÉRIO DA SAÚDE. Secretaria de Atenção à Saúde. Política Nacional de Atenção Básica. 4. ed. Brasília, 2007.

CHIATTONE, H. B. de C. A criança e a hospitalização. In: ANGERAMI-CAMON, V. A. A Psicologia no hospital. São Paulo: Traço, 1986.

BERTOLLI FILHO, C. História da saúde pública no Brasil. São Paulo: Ática, 1996.

GAZINELLI, M. F. et al. Educação em Saúde: conhecimentos, representações sociais e experiências da doença. Cad. Saúde Pública, Rio de Janeiro, v. 21, n. 1, p. 200-206, jan./ fev. 2005.

MARQUES, M. Ó. da S. Saberes escolares: para além da escola. In: RAMAL, A. C. et al. Provocações da sala de aula. São Paulo: Loyola, 1999.

ROSS, P. Fundamentos legais e filosóficos da inclusão na educação especial. Curitiba: IBPEX, 2004.

SASSAKI, R. K. Inclusão: construindo uma sociedade para todos. 4. ed. Rio de Janeiro: WVA, 2002.

WIMMER, G. F.; FIGUEIREDO, G. de O. Ação coletiva para qualidade de vida: autonomia, transdiciplinaridade e intersetorialidade. Ciência \& Saúde Coletiva, v. 11, n. 1, p. 145-154, 2006. Disponível em: < http://www.scielo.br/pdf/csc/v11n1/29458.pdf>. Acesso em: 10 set. 2007. 



\section{AS CONTRIBUIÇÕES DA PSICOLOGIA NA EDUCAÇÃO DE SURDOS: o caso do Centro de Educação Especial do estado da Bahia}

Silvana Correia Silva Antonieta Araújo Marilda Castelar Nicoleta Mendes

\section{INTRODUÇÃO}

No passado, a surdez era confundida com a inferioridade de inteligência e os surdos eram vistos como não educáveis. Acreditava-se que eram incapazes de serem ensinados e por isso eles não frequentavam as escolas e eram privados de alfabetização e instrução. A falta da linguagem oral e a estigmatização em virtude de suas características cognitivas, repercutiam não só no campo educacional, mas em outros âmbitos que os privavam de seus direitos básicos, como a proibição da herança ou possessão de bens, o casamento e o convívio com outras pessoas, ou seja, os surdos eram excluídos da sociedade. E dessa forma, muda e dolorosa, iniciou-se a história educacional do surdo (TALASK, 2006).

A surdez é uma deficiência causada por diversos fatores, alguns provenientes das alterações genéticas e hereditárias, outros das doenças pré, peri e pósnatais, além de outros por uso abusivo de medicações, por acúmulo de cera no ouvido externo - ou ainda por exposição a sons impactantes, que são fatores passíveis de serem evitados. Porém, a perda total ou parcial da capacidade de compreender a fala pelo ouvido, não se constitui um fator de impedimento para 
a aquisição do conhecimento no ensino regular. É verdade, que a ausência da linguagem influi no desenvolvimento educacional dos surdos, quando o ensinoaprendizagem se faz pela técnica da oralização, no entanto o aprender pode ser feito com a utilização de diversas metodologias e recursos, através das aulas ministradas pelo uso da língua de sinais. ${ }^{1}$ (MONDELLI; BEVILACQUA, 2002).

A surdez não é, portanto, impedimento da aquisição de conhecimentos e educação, pois o surdo, mesmo não possuindo o nível de audição para receber os sons da fala, pode ser favorecido de aprendizagem, progresso e integração social.

A educação dos surdos surgiu timidamente em famílias nobres. Segundo Goés (1999) a preocupação com a educação destes se limitava porque eles pertenciam à nobreza, e tinham que manter a aparência e ordem social da época, bem como preservar seus direitos de herança. Aos demais, os desafortunados sobreviviam dependendo da caridade e beneficência da Igreja.

As primeiras instituições voltadas para a educação do surdo se consolidaram na Europa, inicialmente na França, em 1760 e a daí em diante foi disseminada para as demais partes do mundo. Com o advento das instituições especiais, que eram reguladas pela Igreja, estas foram as primeiras escolas produtoras do ensino-aprendizagem de surdos, até então símbolo de primitivismo e irracionalidade. Os primeiros educadores de surdos utilizavam-se de diferentes metodologias de ensino-aprendizagem. Estas consistiam da língua auditivooral nativa, língua de sinais e dactiologia, - representação manual do alfabeto e outros códigos visuais (SKLIAR, 1998).

Refletir sobre a relação Psicologia e Educação, implica pensar nos saberes e práticas educacionais que a Psicologia infere frente a essa questão. Esse projeto pretende resgatar a história das diversas atuações do profissional de Psicologia em um serviço de educação pública para surdos na cidade de Salvador, tornando-se este então o objetivo geral da análise. E como objetivos específicos: registrar a memória e a trajetória das atuações do profissional no centro de referência para a educação de surdos do estado da Bahia, identificando os respectivos interesses destes profissionais no serviço; bem como, as contribuições que porventura realizaram.

No projeto o método utilizado foi uma revisão bibliográfica, baseada no registro de entrevistas semiestruturadas com os psicólogos do campo de análise

\footnotetext{
${ }^{1}$ A língua de sinais não é universal! É a língua nativa da comunidade dos surdos em diversas culturas. No Brasil existe a Língua Brasileira de Sinais (Libras), que é a língua materna dos surdos brasileiros. Na França é a Língua de Sinais Francesa e assim as demais.
} 
- a instituição Centro de Educação Especial da Bahia (CEEBA) através da gravação em áudio digital e em fita cassete. Neste sentido, a educação de surdos, que traz em sua amplitude a educação especial, é um fenômeno cultural e social, o qual necessita ser registrado, arquivado e atualizado, a fim de que promova conhecimento no e explicação de sua história.

O tema escolhido - a atuação do profissional de Psicologia na educação de surdo CEEBA - reflete o interesse em identificar o desenvolvimento dessa atuação, e consequente ao resultado possibilitar o reconhecimento dos profissionais na construção de suas novas práticas e a implementação de ações dirigidas ao surdo no espaço educacional.

Portanto, afirma-se que a educação dos surdos é um assunto inquietante, principalmente pelas dificuldades que impõe e por suas limitações desde tempos remotos; e as recentes propostas educacionais direcionadas para o sujeito surdo têm como reflexo o cenário antigo, uma vez que as diferentes práticas pedagógicas que envolvem os sujeitos surdos apresentam uma série de limitações, e como serão expostos no projeto, esses sujeitos, ao final da escolarização básica, não são capazes de ler e escrever satisfatoriamente ou ter um domínio adequado dos conteúdos acadêmicos, em muitos dos institutos especiais voltados a essa educação.

\section{CARACTERIZAÇÃO DA SURDEZ}

A diminuição da audição (surdez) produz uma redução na percepção de sons e dificulta a compreensão das palavras e essa dificuldade aumenta com o grau de surdez, que pode ser leve, moderado, severo e profundo. A perda auditiva de grau leve geralmente é constatada através do teste de audição (audiometria), visto que as pessoas geralmente não percebem que ouvem com menos facilidade. Quando a perda auditiva passa a ser moderada para severa, os sons podem ficar distorcidos e na conversa, as palavras se tornam abafadas e mais difíceis para serem compreendidas. Quando existem várias pessoas conversando em locais com ruído ambiental ou salas onde existe eco, o grau de surdez é severo, havendo maior dificuldade para ouvir. De acordo com Mondelli; e Bevilacqua (2002), para isto, o indivíduo deve ter perdas auditivas de 90 decibéis.

Os três tipos primários de perda de audição são: a perda condutiva, quando existe um bloqueio no mecanismo de transmissão do som, ou seja, quando a perda auditiva se deve a um problema físico, não sendo, na maioria das pessoas, 
permanentes e podendo ser tratadas com medicamentos ou cirurgias. A segunda refere-se à perda sensoneural que é provocada por problema no mecanismo de percepção do som. Ou seja, o som é passado do ouvido não transmitindo normalmente o som ao cérebro. E a terceira é a perda mista, que inclui componentes, tanto condutivos quanto sensoneurais (LACERDA, 1976).

A incidência da surdez no Brasil tem aumentado muito nos últimos anos e a principal razão está na falta de prevenção dos principais determinantes prénatais, citando as viroses (rubéola, sarampo, caxumba), os protozoários (toxoplasmose), as bactérias (sífilis), o uso de medicações, as patologias que causam alguma ruptura uterina, havendo o deslocamento prematuro da placenta, e gestações de alto risco: como gestantes cardiopatas, diabéticas ou com problema renal (MONDELLI; BEVILACQUA, 2002).

Existem também as causas peri-natais, como parto demorado, difíceis contrações uterinas intensivas e prolongadas, posição inadequada de apresentação fetal, ausência de passagem pelo canal do parto, ruptura precoce da bolsa d'água, ou incompatibilidade do fator RH. No período natal também há registros que geram uma estatística de alta estatística de crianças que nascem geralmente cianozadas (azuladas) devido a problemas de falta de oxigenação cerebral. E por último às causas pós-natais, como: a meningite, desidratação, virose, medicações etc. (MONDELLI; BEVILACQUA, 2002).

\section{O ouvir}

Costuma-se não perceber a importância da audição, a não ser quando começa a faltar a nós próprios, visto que através da audição é possível detectar, discriminar, compreender e localizar os sons da fala. A audição é um dos sentidos que mais nos insere do mundo e, portanto a comunicação humana é um bem de valor inestimável. Além disso, a deficiência na audição pode exercer impacto nas relações sociais do surdo, isto porque geralmente a comunicação verbal é resultante da interação do ser humano em ouvir-falar-ouvir e esta, na maioria das vezes, fica comprometida em se tratando de surdos versus ouvintes, corroborando em algumas situações para isolamento ou exclusão interpessoal (MONDELLI; BEVILACQUA, 2002).

A separação entre grupos de ouvintes e surdos é produzida socialmente, bem como sua integração, na medida em que o preconceito, a discriminação, o comportamento humano está subordinado à cultura que os constrói, propaga, e sedimenta. As normas sociais que "autorizam" essa separação são as mesmas 
que organizam toda a vida social: modos de falar, de vestir-se, de atuar no mundo, de pensar e o modo como a surdez vem sendo descrita ao longo desses períodos. Estudos demonstram que esse olhar sobre os surdos acarreta graves implicações no comportamento social, emocional, psíquico e educacional dos indivíduos. A Psicologia insere-se nesta configuração a partir do momento que traz em seu discurso de ciência e profissão a consolidação de sujeitos em suas relações sociais, no auxílio à construção de identidades e em contribuições de cunho também educacional, psíquico e social (SANTANA; e BERGAMO, 2005).

Quando se aborda o tema educação de surdos é importante que se problematize os termos surdo e deficiente auditivo, uma vez que existem diversos termos denominando esses sujeitos. ${ }^{2}$ As denominações trazem consigo diversos significados e revelam formas de interpretar o mundo, tendo o poder de reproduzir ideias e também preconceitos. Tais significados e interpretações, porém, são dinâmicos, ou seja, mudam de acordo com o momento sócio-histórico e com o contexto. E é também válido para a discussão de como referir-se ao sujeito que tem perda auditiva (SANTANA; BERGAMO, 2005).

Entende-se que o termo deficiência auditiva, é essencialmente técnico e usado na área da saúde, principalmente, quando se fala em patologia. Um dos motivos da não adoção desse termo é que ele não designa o grupo cultural dos surdos, já que eles próprios não se denominam deficientes auditivos. Outro motivo é que este sugere uma conotação de cura, e segundo Santana e Bergamo (2005), fica rejeito, pois traz a ideia higienista da cura, que desconhece as limitações terapêuticas de quem é surdo e também porque nega a identidade e cultura surda, ignorando suas possibilidades de construção subjetiva e social.

Portanto é importante descrever que na atualidade, de acordo com a legislação estabelecida pelo decreto federal n. 5.626, de 22 de dezembro de 2005, que regulamenta a lei n. 10.436, de 24 de abril de 2002, "denomina-se pessoa surda, aquela que, por ter perda auditiva, compreende e interage com o mundo por meio de experiências visuais, manifestando sua cultura principalmente pelo uso da Língua Brasileira de Sinais - Libras" (BRASIL, 2002).

Além do mais, ainda existe segundo a Federação Nacional de Educação e Integração dos Surdos (FENEIS), a denominação surdo-mudo que é a mais antiga e incorreta denominação atribuída ao surdo e, infelizmente ainda utilizada em certas áreas e nos meios de comunicação. O fato de uma pessoa ser surda não significa que ela seja muda. A mudez seria outra deficiência. O surdo é o

\footnotetext{
${ }^{2}$ Nesse contexto serão denominados surdos.
} 
individuo no qual a audição não é funcional para todos os sons e ruídos ambientais da vida; que apresenta altos graus de perda auditiva prejudicando a aquisição da linguagem e impedindo a compreensão da fala através do ouvido, com ou sem aparelhos necessitando de próteses auditivas altamente potentes.

Temos assim uma breve caracterização sobre a surdez, cuja exposição oferecerá margem as próximas temáticas que dela repercutem como as questões sociais e educacionais.

\section{A TRAJETÓRIA HISTÓRICA DA EDUCAÇÃO DE SURDOS}

Antes de adentrar neste tema, é importante resgatar brevemente a história da representação social do surdo, anterior ao advento da educação especial e a história desta educação e a sua evolução. Observando a trajetória histórica do ontem e o processo hoje, a história da humanidade foi testemunha de como os surdos foram excluídos da sociedade.

Segundo Talask (2006), na Antiguidade clássica, a preocupação dos homens movia-se na busca daquilo que considerava a perfeição: a arte, a ciência, a técnica da retórica. Embora este momento histórico não traga na literatura muitas referências quanto aos surdos, é sabido que em Esparta crianças portadoras de alguma deficiência, o que inclui a surdez, eram consideradas subumanas o que legitimava sua eliminação ou abandono. De acordo com os autores supracitados, no sistema político romano, os surdos eram confundidos com os débeis mentais, e, portanto eram privados de seus direitos, considerados irracionais e eram exterminados.

Durante a Idade Média, as estruturas sociais eram definidas por leis divinas, sob domínio da Igreja Católica, que condenava o infanticídio, e fornecia a ideia de atribuir as "anormalidades" que apresentavam os surdos as causas sobrenaturais. Qualquer ideia ou pessoa que pudesse atentar a esta estrutura teria de ser exterminada. Nesse período, os surdos também começam a escapar do abandono e da exposição, passando a ser acolhidos em conventos ou igrejas, cujas paredes convenientemente isolavam e escondiam o incômodo ou inútil. No período da Inquisição, a ideia de perfeição proferida pela Igreja deixava os surdos ou os "imperfeitos", à margem da condição humana, assim eram queimados em fogueiras com a alegação de que se opunham à Igreja. A Inquisição religiosa bem cumpriu esse papel, quando sacrificou como hereges ou endemoniados, milhares de pessoas, entre elas loucos, alucinados e surdos (TALASK, 2006). 
É importante ressaltar que até o início da Idade Moderna não existem registros de experiências educacionais com os surdos, a não ser quando pertencia a famílias nobres. Este era ensinado por professores ou preceptores para que fosse treinado para a aquisição da fala, porque sem ela não lhes eram garantidos os direitos legais como um membro da família. Os preceptores educavam com a escrita e alfabeto digital, criado para que o surdo pudesse ler com os olhos, ensinavam também a leitura-escrita e diferentes técnicas para desenvolver habilidades como a leitura labial. Sendo o surdo não pertencente a tais famílias era visto como não cidadão; pessoas castigadas e enfeitiçadas, forçadas a fazer os trabalhos mais desprezíveis; vivendo sozinhas e abandonadas na miséria. Eram considerados pela lei e pela sociedade como imbecis e não tinham nenhum direito (TALASK, 2006).

Segundo Nascimento (1999), nesse período a apologia era o método experimental, onde se valorizava a observação, os testes e as hipóteses. Assim, com o surgimento do método científico, decorrente do modelo médico, impregnado de noções com forte caráter de patologia, doença, medicação e tratamento, iniciam-se estudos sobre deficiências, incluindo a surdez.

Assim, inicia-se a história da educação dos surdos que teve seu início marcado por duas vertentes: a religiosa e a médica. Com relação à religião, atitudes caritativas e de auxílio ao próximo faziam parte dos preceitos religiosos. Os padres, abades ou ordens inteiras se responsabilizavam pelo cuidado e educação dos surdos. Quanto à medicina, a surdez era caracterizada como uma deficiência relacionada a uma anomalia orgânica da qual despertava atenção e interesse de alguns médicos nesta área do conhecimento (SKLIAR, 1998).

$\mathrm{O}$ interesse dos médicos sobre a surdez, poderia ser atribuído ao importante papel da medicina no período da revolução científica, em especial da anatomia, em que passaram a se dedicar ao estudo da fala dos surdos, assim como de suas possibilidades de aprendizagem (SKLIAR, 1998). Desta forma, foi estabelecida uma estreita relação entre educação e medicina. Com base nesta compreensão, as atitudes para com os surdos se modificam, à medida que lhes foram oferecidas oportunidades educacionais e de integração social. 


\section{A primeira instituição de surdos}

A primeira instituição especializada para a educação de surdos, chamados à época surdo-mudo foi fundada em $1770^{3}$ em Paris, pelo Abade Charles Michel de L'Eppé. A educação do surdo tinha a preocupação de capacitar o aluno na aquisição de um código linguístico a fim de que eles pudessem estar imersos no contexto social. A primeira escola utilizou a língua de sinais, uma combinação dos sinais com a gramática francesa, com o objetivo de ensinar a ler, escrever e transmitir a cultura, oferecendo de tal forma o acesso à educação. O método de L'Epée teve sucesso e obteve resultados espetaculares na história da surdez. Em 1791, a sua escola se transforma no Instituto Nacional de Surdos e Mudos de Paris, sendo mais tarde dirigida pelo seu seguidor o gramático Abad Sicard (PINTO, 2007). Cabe ressaltar que os primeiros institutos, de acordo com Talask (2006, p. 5):

Eram escolas que estimulavam os surdos e os cegos a fazerem trabalhos manuais e a se comunicarem por gestos [...] e serviram de modelo para a criação de muitas outras escolas em outros países. O sustento dos surdos [...] era adquirido através da venda dos trabalhos manuais realizados dentro das instituições. $\mathrm{O}$ aprendizado da leitura, da escrita, dos cálculos e das artes demorou muito para ser adotado pelos institutos.

Os surdos, conforme afirmam Monteiro e Andrade (2005) têm enormes dificuldades para interiorizar um código linguístico oral, no entanto, maiores facilidades para um código linguístico de sinais. E é por esse fato da concentração exclusiva da educação do surdo na oralização, que o nível educacional deste caiu muito, o que só começou a ser modificado no mundo em 1980. Na mesma época na Alemanha, foi criada a escola pública para surdos, ensinando métodos orais de comunicação.

A educação do surdo se desenvolveu em diferentes direções, ao longo do tempo. Existiam professores que divergiam quanto ao método mais indicado para ser adotado no ensino dos surdos. Uns acreditavam que o ensino deveria priorizar a língua falada - Método Oral Puro - e outros a língua de sinais, além do ensino da fala com sinais - Método Combinado ou Bilinguismo. Segundo

\footnotetext{
${ }^{3}$ Em obras de Matos encontrou-se que o período da fundação da primeira instituição para surdos em Paris data de 1770 e outros autores, como Cabral reporta a 1712, a data de nascimento de Abade L’èppe, o fundador da instituição.
} 
Skliar (1998), houve a partir do século XIX conflitos entre duas alternativas pedagógicas que melhor reinseriria o surdo na sociedade: de um lado a alternativa do uso de sinais, também chamando de Dactiologia de Abade de L' éppé, que consistia em comunicar-se por via de gestos com a mão. E por outro lado, a alternativa oposta, defendida por Samuel Hernicke, que acreditava na modalidade oral da língua, pois seria a única forma desejável de comunicação do surdo.

Além de Hernicke e L'Epée, alguns professores também se dedicaram à educação do surdo e se destacaram: Ivan Pablo Bonet, na Espanha; Moritz Hill, na Alemanha; Alexandre Gran Bell, no Canadá e EUA; Ovide Decroly, na Bélgica.

\section{A educação do surdo no Brasil}

No Brasil, a história da educação do surdo iniciou-se com a criação do Instituto de Surdos-Mudos, hoje Instituto Nacional de Educação de surdos (Ines). O instituto foi fundado em 26 de setembro 1857, no Rio de Janeiro, pelo professor surdo francês Hernest Huet, que por meio do decreto imperial veio ao Brasil a convite do Imperador D. Pedro II. Inicialmente, o instituto foi um asilo, onde só eram aceitos surdos do sexo masculino. Eles vinham de todos os pontos do país e muitos eram abandonados pelas famílias. Somente a partir do ano de 1931 é que o atendimento foi ampliado e então se criou o externato feminino com oficinas de costura e bordado (INES, 1998).

No instituto os surdos eram educados por linguagem escrita, articulada e falada, dactilogia e sinais. A partir de então, os surdos brasileiros passaram a contar com uma escola especializada para sua educação e tiveram a oportunidade de criar a Língua Brasileira de Sinais (Libras), mistura da Língua de Sinais Francesa com os sistemas de comunicação já usados pelos surdos das mais diversas localidades (INES, 1998).

É importante salientar que o recurso da Língua de sinais apresenta-se de forma autônoma e reconhecida, visto que possui uma organização linguística semelhante à língua oral. Contudo, ainda é preciso uma revisão em suas legislações, em função das constantes transformações sociais, da evolução dos conhecimentos do surdo e, principalmente, das regências dos centros educacionais.

O Imperial de Surdos Mudos, atual Ines, em 1993 tornou-se a primeira instituição federal, centro de referência para a educação de surdos, assim como em 1951 criou o primeiro curso de formação de professores para eles. Desse período em diante o Ines realizou várias ações e foi adquirindo mudanças em 
sua prestação de serviços, que tem por objetivo oferecer aos seus alunos melhores condições educacionais (INES, 1998). É importante ressaltar que não foram encontrados registros que mencionassem a participação da Psicologia até então para apoiar a revisão bibliográfica.

Entre o período de 1905 a 1950, muitas instituições particulares foram criadas para o atendimento dos surdos, vale ressaltar seu acentuado caráter assistencialista. As iniciativas oficiais também aconteceram neste período, porém tanto as instituições particulares quanto as oficiais não foram suficientes para atender o número de surdos existentes (CAMPOS, 2003). Dessa forma, a educação de surdos no Brasil foi se ampliando lentamente, pois foram sendo criados mais institutos particulares. Os serviços públicos eram prestados através das escolas regulares, que ofereciam classes especiais para o atendimento e dessa forma, no século XX, o número de escolas para surdos aumentou em todo o mundo. No Brasil, surgiu o Instituto Santa Terezinha para meninas surdas em São Paulo; a Escola Concórdia, em Porto Alegre; a Escola de Surdos de Vitória, o Centro de Audição e Linguagem Ludovico Pavoni CEAL/LP, Brasília e várias outras que, assim com o Ines e a maioria das escolas de surdos do mundo, passaram a adotar o método oral (PINTO, 2007).

Assim como em outros países, no Brasil, houve a disputa entre duas alternativas da comunicação do surdo. A princípio foi adotada a Libras, até que foi abolida e adotado o oralismo puro. A partir da década de 1960, surgiu um movimento em defesa da educação bilíngue, e segundo Nascimento (1999), a partir dos estudos sobre a Língua Americana de Sinais, houve novos parâmetros para se pensar na educação do surdo.

Na década de 1970, chegou ao Brasil a filosofia da comunicação total, que consiste no uso de todos os recursos linguísticos: orais ou visuais, simultaneamente, privilegiando a comunicação, e não apenas a língua. Na década seguinte, foi consolidado o bilinguismo que acredita que o surdo deve adquirir a língua dos sinais como a língua materna, com a qual ele poderá desenvolver-se e comunicar-se com a comunidade de surdos. Tendo secundariamente a língua oficial de seu país como segunda língua. Atualmente, existem três filosofias educacionais que ainda persistem paralelamente no Brasil: a Libras, a comunicação total e o bilinguismo. (GLAT; FERNANDES, 2005).

Na Bahia durante os anos 1970, a preocupação da Psicologia quanto à educação de surdos compartilhava com outra questão: a higiene mental. Alguns pensadores como Teixeira Brandão, Henrique Roxo, Raimundo Nina Rodrigues, Juliano Moreira, Afrânio Peixoto e Ulisses Pernambucano, estavam 
preocupados com questões acerca das patologias oriundas das disfunções psíquicas (CAMPOS, 2003).

No âmbito da Pedagogia, Medeiros e Albuquerque, Isaías Alves, Manuel Bomfim contribuíram para a construção de uma Psicologia desvinculada da prática psiquiátrica, neurológica ou assistencial, mas voltada para a educação. Outros nomes como Anísio Teixeira e Helena Antipoff se destacaram também em trabalhos cujos temas da Psicologia emergiam no processo de ensino-aprendizagem de surdos (CAMPOS, 2003).

\section{Leis para a educação de surdos}

$\mathrm{Na}$ década de 1950, vinham sendo iniciadas discussões quanto às leis voltadas para o direito da educação do surdo e que consistia na luta de pequenos grupos participantes para a aprovação da lei que, segundo Kassar (2007), girava em torno de "uma escola para todos: laica e gratuita".

Na década de 1980, importantes movimentos em favor dos direitos civis provocaram iniciativas em torno da integração do surdo na sociedade. Na prática, o rompimento com os modelos segregadores (ruptura esta não efetiva) resultou em iniciativas voltadas à integração no âmbito escolar. Este movimento foi desencadeado de forma mais consistente a partir de 1987, com a reformulação do sistema estadual de ensino, que garantiu a efetivação da política de integração do surdo, na rede comum de escolarização estabelecida no plano para a campanha de matrícula escolar da Secretaria da Educação entre os anos de 1987-1991 (TALASK, 2006).

A garantia do direito de todos à educação, a propagação das ideias de normalização e de integração dos surdos e o aprimoramento das próteses ortofônicas fizeram com que surdos de diversos países passassem a ser encaminhados para as escolas regulares. No Brasil, as secretarias estaduais e municipais de educação passaram a coordenar o ensino e surgiram as salas de recursos e classes especiais para surdos, além de algumas escolas especiais, com recursos públicos ou privados (KASSAR, 2007).

Foi somente no ano de 1996 que foi organizada a nova Lei de Diretrizes e Bases da Educação Nacional (LBDEN) de modo que a ação pudesse ter uma lei que fosse condizente com a Constituição Brasileira. A nova LDBEN trouxe algumas inovações, não só para a educação em geral, como também para a educação especial, na qual foi dedicado um capítulo referente à inclusão escolar para alunos surdos (CARMO, 2005). 
Segundo o texto da Constituição de 1988, é garantido aos surdos o atendimento especializado, preferencialmente na rede regular de ensino; e estabelecidos currículos, métodos, técnicas, recursos educativos e organização específica, para atender às suas necessidades. Além disso, regulamentou-se a especialização adequada de professores que prestam atendimentos particulares, bem como a capacitação de professores do ensino regular para a integração dos surdos nas classes comuns, visando a sua efetiva integração social. A regulamentação citada acima foi estabelecida pelo Ministério da Educação e denominada adaptação curricular de grande e pequeno porte - uma estratégia para determinar aos professores o ensino e o atendimento especializado aos surdos a fim de facilitar a aprendizagem destes (BRASIL, 1988).

Conforme Kassar (2007), essa preparação deverá ocorrer em sala de aula, em setores operacionais da escola e na comunidade, pois mesmo com o amparo das leis ainda é preciso lutar, participar das políticas comunitárias dentro das escolas, das clínicas, dos órgãos públicos buscando as mudanças das políticas educacionais. Deverá haver ação conjunta do diretor e dos professores da escola, das autoridades educacionais, dos líderes do movimento dos surdos e representantes da comunidade. Assim não só a escola se torna integradora, mas toda sociedade contribuindo e desenvolvendo juntas parcerias para um futuro melhor.

Ainda assim, identifica-se que o aluno surdo tende a ser rejeitado pelo professor, que acha que ele tem a responsabilidade apenas para com o aluno que responde. $\mathrm{O}$ surdo que tem dificuldade em acompanhar a aula é algumas vezes visto como não pertencente à sala de aula. Quando um surdo tem dificuldades quanto à aprendizagem e a leitura, supõe-se que a causa esteja mais no aluno do que nas condições a ele oferecidas. E mesmo quando as condições para aprendizagem são alteradas como quando o surdo é colocado numa classe especial, ainda supõe-se fundamentalmente, que o problema esteja no surdo (PINTO, 2007).

É importante salientar que, a educação do surdo deve ser baseada na visão e não na audição. A lei dá abertura para as adaptações curriculares, podendo assim todo o sistema educacional adaptar sua metodologia para atender a todos sem distinção. As mínimas mudanças na metodologia e nos recursos podem trazer diferenças perceptíveis na educação do surdo, ou seja, as modificações em sala de aula podem ser simples, mas se executadas podem resultar em amplas diferenças.

Por exemplo, ao trabalhar com o surdo, é necessário o uso de materiais visuais, ao invés do uso dos mesmos recursos utilizados no ensino da educação dos ouvintes; a integração dos surdos em um grupo de trabalho com pessoas 
que tenham mais disponibilidade e paciência, a aprendizagem de professores e alunos em alguns sinais básicos da Libras, trazem impacto bastante significativo no desenvolvimento do surdo. Além disso, articular a fala com o surdo de maneira mais cautelosa, através de frases curtas, com o tom de voz normal e melhor pronunciação das palavras, não usando muitos gestos e nem qualquer objeto na boca, permitindo assim que ele faça a leitura labial, também possibilita e contribui para a evolução e o desenvolvimento saudável do surdo (BRASIL, 2002).

A proposta é de uma ética que se propõe: ao respeito ao próximo, - e ao combate das atitudes discriminatórias, bem como a conscientização dos surdos sobre seus direitos e não só deveres, - essas são algumas das possibilidades e contribuições da Psicologia como ciência e profissão na educação pública do surdo para que possam conviver igualitariamente na sociedade e sendo reconhecidos como indivíduos surdos, não sendo apresentados com estereótipos de ineficientes e incapazes, que ainda hoje lhe são atribuídos.

\section{A INSERÇÃO DA PSICOLOGIA NA EDUCAÇÃO DE SURDOS}

A inserção da Psicologia no sistema educacional público incidiu no panorama caracterizado por um limitado mercado de trabalho, onde estava sendo difícil absorver o número crescente de profissionais recém-formados que procuravam uma área de atuação, restritamente a clínica. A preocupação da Psicologia direcionada a realidade social, também propiciou a sua atuação na educação pública dos surdos, pois até então a sua atuação era destinada a uma pequena parcela da população e o modelo clínico era fortemente caracterizado por um conteúdo ideológico, individualista e despreocupado com os problemas sociais. Então a partir dessa percepção, o psicólogo passou a se preocupar e a oferecer assistência psíquica aos surdos, que desde tempos remotos mantiveram-se segregados no âmbito social e viviam em condições de marginalização e estigma (GLAT; FERNADES, 2005).

Assim, segundo Matos (1994), os serviços públicos passaram a ser um campo atrativo, havendo uma convergência de psicólogos para as instituições públicas. Esse período iniciou-se na década de 1990 "quando a Psicologia estava engajada a oferecer a sua parcela de contribuição ao setor público de educação." (MATOS, 1994, p. 51). É nesse contexto que o profissional adentrou a fim de diagnosticar e trabalhar com as diferenças individuais e sociais na educação do surdo. 
Ressalvando o parágrafo acima supracitado e refletindo sobre este, percebe-se que a atuação da Psicologia na educação do surdo teve seu início tardio e constituído originalmente como campo de saber e área de atuação a partir de um modelo médico e clínico. Sob esse enfoque e de acordo com Skliar (1998) a deficiência era entendida, na época, como uma doença crônica, e todo o atendimento prestado aos surdos, mesmo quando envolvia a área educacional, era considerado pelo viés terapêutico. A primeira prática psicológica dirigida a essa clientela partia de âmbitos fisiológicos e estereotipados, através de uma avaliação e identificação, pautadas em exames médicos e psicológicos com ênfase nos testes projetivos e de inteligência, e rígida classificação etiológica.

Matos (1994) esclarece e em concordância com Kassar (2007), afirma que nesse período a prática de atuação dos psicólogos visava avaliar as capacidades cognitivas e planejar programas de educação adequados aos diversos níveis de escolaridade para a formação escolar do surdo. E ressalva que, ao longo do tempo, a contribuição da Psicologia estará muito além dos aspectos educacionais e direcionar-se-á para a orientação e formação da cidadania, bem como no fortalecimento de identidade enquanto pessoa surda e a conscientização dos direitos pelos quais têm.

Assim a função da Psicologia tem muito em comum com a do professor na medida em que ele procura usar o sistema educacional público para aumentar a qualidade e a eficiência do processo educacional do surdo. Ao colaborar no planejamento de programas educacionais, o profissional de Psicologia pode se valer de inúmeros métodos e materiais, podendo se lançar a mão de testes psicológicos (TALASK, 2006).

\section{Testes psicológicos e triagem}

A avaliação psicológica é uma atividade profissional bastante questionada e controvertida na Psicologia, visto que inicialmente, suas fundamentações resultaram em diagnósticos errôneos e discriminatórios que levaram a rotulação de muitas pessoas, que se submeteram aos testes, como - "doentes e débeis mentais”. Além disso, a pouca precisão científica de seus resultados e os métodos psicofísicos, contribuíram também para que o surgimento da avaliação psicológica fosse marcado pelas críticas e pela pouca simpatia da sociedade. (PASQUALI, 2001).

De acordo com Monteiro e Andrade (2005), à medida que os métodos, técnicas e recursos na Psicometria foram sendo aperfeiçoados, bem como o com- 
prometimento com a realidade social e a ética dos profissionais, houve o progresso e a continuidade na elaboração de diversos testes psicológicos que hoje evidenciam com veracidade seus resultados. Entretanto, há uma escassez no que diz respeito aos testes desenvolvidos especificamente aos surdos. Na busca de estudos sobre a Psicometria que possam avaliar alguns aspectos dos surdos, encontram-se poucas evidencias no Brasil. E quando encontradas, a maioria das pesquisas foram realizadas por linguistas e fonoaudiólogos e consistiam em métodos de comunicação e educação, treinamento de professores, desenvolvimento da linguagem e relacionamento dos surdos com seus familiares e profissionais

Apesar de poucos, existem alguns instrumentos, desenvolvidos por psicólogos, que auxiliam as práticas com os surdos: Escala de Maturidade Mental Colúmbia (CMMS), Teste de Desempenho Escolar (TDE) e Consciência Fonológica Instrumento de Avaliação Sequencial (CONFIAS), todos validados pelo Conselho Federal de Psicologia.

Entretanto, quando o profissional de Psicologia ingressa no sistema educacional público de surdos, ele releva possibilidades e deixa de analisar condicionantes, fundamentais na avaliação psicológica. De acordo com Talask (2006, p. 63):

Nada é feito no sentido de examinar as condições sob as quais a
criança 'tem' seus problemas e quando é feito o psicólogo cai no
erro comum de permitir que os testes tomem decisões por ele [...].
Os resultados de tais testes ajudar-no-iam a tomar decisões funda-
mentais sobre certos aspectos do problema de uma criança.

Além disso, Pasquali (2001) retifica a ausência de testes não adequados para avaliação psicológica do surdo e menciona a importância da construção de testes que se constituam da Libras, que é a língua oficial dos surdo:

Os surdos têm desvantagens nos teste verbais, mesmo quando estes são apresentados visualmente. Pode-se pensar que o motivo para isso é que o conteúdo verbal apresentado nos testes psicológicos está na Língua Portuguesa, e não na estrutura gramatical diferente da Língua Brasileira de Sinais (LIBRAS), a língua oficial do surdo. (PASQUALI, 2001, p. 35).

Assim, observa-se a necessidade de explorar testes que avaliem os aspectos cognitivos e emocionais de surdos por meio de situações padronizadas e 
instrumentos válidos, garantindo maior veracidade científica, bem como de profissionais qualificados e preparados para lidar com os surdos.

\section{RESULTADOS E ANÁLISES}

No Estado da Bahia, o CEEBA é um centro de referencia, especializado e complementar ao atendimento de alunos portadores de quaisquer necessidades especiais, cujo objetivo consiste na integração destes no ensino regular e comunitário. Na unidade são oferecidos serviços educacionais, de apoio especializado e profissional formado por psicólogo, assistente social e pedagogo.

O primeiro respaldo desta análise se refere ao objetivo da implantação do CEEBA. Este centro foi planejado para atender ao surdo, no entanto quando se consolidou tornou-se um centro para múltiplas deficiências, e que pela constatação das entrevistas realizadas aos profissionais, (que atualmente estão ainda trabalhando na unidade) o CEEBA não tem suporte financeiro e físico para a demanda que procura a instituição e, portanto, tem que recorrer a outras instituições que possam suprir essa demanda e por assim fazem seus encaminhamentos.

Sob a análise da atuação dos profissionais de Psicologia na instituição CEEBA, é importante fazer o segundo destaque para a costumeira "tradição" dos profissionais ainda hoje encontrar-se em desvio de função. Ressalva-se que desde a fundação do Centro de Referencia, o profissional assumira as atribuições e a função de Psicólogo. No entanto, era nomeado como Pedagogo, isso porque, em relato de uma das entrevistadas, o CEEBA estava ligado a Secretaria de Educação que "não contratava psicólogos [...] Então se você era professor e tinha formação em Psicologia [...] trabalharia com desvio de função e na sua carteira profissional, o seu contrato com o Estado era de professor e você atuava como psicólogo." E desta forma novatos entravam, veteranos saiam e repassava-se de uns para outros essa nomeação.

Esse panorama antigo e atual do desvio de função leva a indagação sobre até onde ou com qual frequência os profissionais de Psicologia repensam suas práticas, refletem sobre seu lugar e suas contribuições sociais. Ou seja, já se passaram anos e os profissionais de Psicologia continuam em desvio de função, no setor de educação pública.

É perceptível também a falta de comprometimento do profissional da área, no que se estende desde o acolhimento do aluno surdo na instituição, ao acompanhamento deste durante sua permanência na unidade e a sua saída para 
o mercado de trabalho. Ou seja, é inexistente qualquer atividade atribuída pelo Código de Ética do Psicólogo na educação especial ou irrelevante seu desempenho em relação às suas reais atribuições, visto que a sua real atuação basicamente se constitui na promoção e desenvolvimento do surdo, do acompanhamento e auxílio na evolução de experiências dele, pois é direito deste: receber um ensino que enfatize os processos de desenvolvimento de suas potencialidades e sua inserção ao grupo social, recebendo equidade de tratamento sem distinção. E conforme a Constituição Federal de 1988, ser respeitado, ser atendido em suas dificuldades e ser incentivado no desenvolvimento e funções.

Além disso, identifica-se a desqualificação na formação acadêmica e a posteriori no aperfeiçoamento/aprimoramento da atuação deste profissional. Muitos deles, nunca passaram por qualquer curso de aperfeiçoamento ou treinamento para o trabalho com o surdo. Esse fato é explicito na entrevista realizada com todos eles, visto que $100 \%$ dos profissionais de Psicologia não sabem a Libras, que é a língua oficial dos surdos no Brasil, mostrando nitidamente que não existe a preocupação profissional em oferecer um atendimento mínimo, que é a comunicação, com este aluno.

Logo há o questionamento: Senão, a Libras, qual a ferramenta que deve ser usada pelo profissional no atendimento ao surdo? E então o profissional está preparado para atender esse público? Raramente são encontrados profissionais, na cidade de Salvador, conhecedores e habilitados para o uso da Libras e essa realidade tem se constituído em grande impedimento para que os surdos recebam atendimento necessário para o seu desenvolvimento.

Mais um dado identificado no CEEBA, e de importância a se destacar, é à ausência de uma equipe especializada e completa de profissionais na educação especial. O CEEBA atualmente consta apenas com "alguns psicólogos, pedagogos e psicopedagogos". Basicamente o que prejudica e desqualifica o atendimento especializado prestado aos alunos surdos, pois por lei federal é obrigatório a presença e atuação de psicólogos, terapeutas ocupacionais, fonoaudiólogos, pedagogos, fisioterapeutas, médicos na instituição especial.

De acordo com a lei federal, decreto n. 5.626, de 22 de dezembro de 2005, que tem em vista o disposto a lei n. 10.436, de 24 de abril de 2002 e no artigo 18 da lei n. 10.098, de 19 de dezembro de 2000, todo centro de educação especial deverá possuir uma equipe completa e especializada em cada área de deficiência, bem como todo o profissional que deverá ser admitido e em algum centro submeter-se a cursos de treinamento na respectiva área. 
Além disso, qualquer centro de educação de surdos tem como mínimas finalidades: realizar a promoção da educação; reabilitar e integrar educacional, emocional, social, cultural e profissionalmente na comunidade os surdos através do ensino e programas que visem ao desenvolvimento de suas potencialidades; além de garantir o direito à informação e à comunicação, com as adaptações necessárias; assegurar a participação dos pais no aperfeiçoamento e gestão da educação de surdo e o respeito à dignidade do cidadão, à sua autonomia e ao seu direito ao serviço de qualidade, bem como à convivência familiar.

Contudo, é importante ressaltar que com todas as dificuldades que a instituição passa como o deficitário ou insuficiente repasse financeiro que recebe da Secretaria de Educação e as condições da estrutura física, ainda hoje, o CEEBA oferece, dentro desses empecilhos 22 oficinas pedagógicas de treinamento e produção (no turno matutino e vespertino), como a padaria; o artesanato diversificado (papel, crochê, costura, bordado) a lavanderia e cozinha industrial; teatro; capoeira dentro das aulas de educação física e o ensino primário; integração escola-empresa (encaminhamento para o mercado de trabalho), além dos serviços de apoio da Psicologia, Serviço Social e Psicopedagogia.

\section{CONCLUSÃO}

A partir de alguns dos resultados aqui colocados como relevantes conclui-se que o CEEBA atribuído como referência estatal na educação especial, não tem a mínima qualificação e quantidade suficiente de profissionais que possam atender a demanda de pessoas que procuram serviço, e quando atende deixa de suprir a maior e melhor necessidade, que é oferecer um serviço completo e qualificado. Além do mais, é importante mais uma vez salientar a insuficiência de profissionais de Psicologia que restaram no CEEBA e que continuam atuando com desvio de função, praticando suas atividades desqualificadamente e, sem a conscientização da importância de sua atuação nesse contexto.

Talvez essa atuação do psicólogo seja em resposta a historia que se fez recentemente na educação pública e/ou a surdez ser considerada até pouco tempo de cunho social e não médico ou religioso. Engana-se aos profissionais que atuam se respaldando nessa afirmativa, visto que se passaram anos desde aquela fundamentação e até hoje não há mudanças tão significativas na educação pública do surdo, a não ser por uma parcela da população que luta por tais modificações ou pelo setor de educação especial particular ou especializado e a clínica. 


\section{REFERÊNCIAS}

BRASIL. Decreto federal no ${ }^{\circ}$ 5.626, de 22 de dezembro de 2005. Regulamenta a lei ${ }^{\circ}$ 10.436, de 24 de abril de 2002. Brasília. Disponível em: < http://www.planalto .gov.br/ccivil_03/_ato2004-2006/2005/decreto/d5626.htm >. Acesso em: 23 nov. 2009.

. Constituição (1988). Constituição da República Federativa do Brasil. São Paulo: Saraiva, 1988.

. Lei n. 9.394, de 20 de dezembro de 1996. Estabelece as diretrizes e bases da educação nacional. Brasília, 1996. Disponível em: < http://www.planalto.gov.br/ ccivil_03/ Leis/ L9394.htm\# art92 >. Acesso em: 15 set. 2007.

CAMPOS, Regina Helena de Freitas. Helena Antipoff: razão e sensibilidade na Psicologia e na educação. Estudos Avançados, São Paulo, v. 17, n. 49, set. 2003.

CARMO, Sônia Maria do. Um breve panorama do que já foi feito pela educação especial no Brasil e no mundo. São Paulo: Pedagogo Brasil, 2005. Disponível em: $<$ http://www.pedagobrasil.com.br/educacaoespecial/umbrevepanorama $>$. Acesso em: 20 nov. 2009.

GLAT, Rosana; FERNANDES, Edicléa Mascarenhas. Da educação segregada à educação inclusiva: uma breve reflexão sobre os paradigmas educacionais no contexto da educação especial brasileira. Inclusão: Revista Periódica da Educação Especial. v . 1, n. 1, p. 35-39. out. 2005 .

GOES, Marília Cecília Rafael de. Linguagem, Surdez e Educação. 3. ed. São Paulo: Autores Associados, 1999. p. 19-24; 39-49.

INSTITUTO NACIONAL DE EDUCAÇÃO DE SURDOS. Aquisição de Primeira Língua e Segunda Língua: diferenças no processo de aquisição entre pessoas surdas e ouvintes. Rio de Janeiro, 1998.

. O Surdo e a história de sua educação. Disponível em: < http://www.ines.gov.br/ ines_livros/31/31_PRINCIPAL.HTM >. Acesso em: 25 nov. 2009.

KASSAR, Monica de Carvalho Magalhães. Liberalismo, neoliberalismo e educação especial: algumas implicações. Cadernos CEDES, Campinas, v.19, n. 46, fev. 2007.

LACERDA, Armando Paiva de. Audiologia clínica. Rio de Janeiro: Guanabara, 1976.

MATOS, Aécio Gomes de. Alienação do serviço público. Revista Ciência e Profissão, Brasília, v. 14, n. 1-3, 1994.

MONDELLI, Maria Fernanda Capoani Garcia; BEVILACQUA, Maria Cecília. Estudo da deficiência auditiva das crianças do HRAC-USP, Bauru-SP: subsídios para uma política de intervenção. São Paulo: Moreira Jr, 2002.

MONTEIRO, Janine Kieling; ANDRADE, Clarissa Galecki. Fundamentos da testagem psicológica. Testes psicológicos para surdos. Aletheia, Porto Alegre, n. 21, jan./jun. 2005.

NASCIMENTO, Lilian Cristine. Uma análise dos percursos discursivos da prática fonoaudiológica no Brasil. 1999. 01-109 páginas. Dissertação (Mestrado em Educação) Universidade de Campinas, Campinas, 1999. 
PASQUALI, Luiz. Técnicas de exame psicológico - TEP: manual. São Paulo: Casa do psicólogo, 2001.

PINTO, Fernanda Bouth. Vendo vozes: a história da educação dos surdos no Brasil oitocentista. 2007. Disponível em: < http://www.cultura-surda.eu>. Acesso em: 25 nov. 2009.

SANTANA, Ana Paula; BERGAMO, Alexandre. Cultura e identidade surdas: encruzilhadas de lutas sociais e teóricas. Educ. Soc., Campinas, v. 26, n. 91, p. 565-582, maio/ago. 2005. Disponível em: < http://www.cedes.unicamp.br>. Acesso em: 25 nov. 2009.

SKLIAR, Carlos (Org.). A surdez: um olhar sobre as diferenças. Porto Alegre: Mediação. 1998.

TALASK, Anamelia Gomes. Psicologia e surdez: a importância do conhecimento da língua brasileira de sinais (LIBRAS) pelo gestalt-terapeuta. Dissertação (Graduação). Faculdades Integradas Maria Thereza. Niterói. p. 1-46. 2006. 


\section{ACESSIBILIDADE TECNOLÓGICA}

Teófilo Alves Galvão Filho

\section{A TECNOLOGIA ASSISTIVA - DE QUE SE TRATA?}

Conforme o conceito adotado em 2007 pelo Comitê de Ajudas Técnicas, da Secretaria Especial dos Direitos Humanos da Presidência da República (SEDH/PR),

Tecnologia Assistiva é uma área do conhecimento, de característica interdisciplinar, que engloba produtos, recursos, metodologias, estratégias, práticas e serviços que objetivam promover a funcionalidade, relacionada à atividade e participação de pessoas com deficiência, incapacidades ou mobilidade reduzida, visando sua autonomia, independência, qualidade de vida e inclusão social. (BRASIL, 2007).

É considerada Tecnologia Assistiva, portanto, desde artefatos simples, como uma colher adaptada ou um lápis com uma empunhadura mais grossa para facilitar a preensão, até sofisticados programas especiais de computador que visam à acessibilidade.

Hoje em dia, é sabido que as Tecnologias de Informação e Comunicação (TIC) vêm se tornando, de forma crescente, importantes instrumentos de nossa cultura e, sua utilização, um meio concreto de inclusão e interação no mundo (LEVY, 1999). Essa constatação é ainda mais evidente e verdadeira quando nos referimos a pessoas com deficiência. Nesses casos, as TIC podem ser utilizadas ou como Tecnologia Assistiva, ou por meio de Tecnologia Assistiva. Utiliza-se as TIC como Tecnologia Assistiva quando o próprio computador é a ajuda 
técnica para atingir um determinado objetivo. Por exemplo, o computador utilizado como caderno eletrônico, para o indivíduo que não consegue escrever no caderno comum de papel. Por outro lado, as TIC são utilizadas por meio de Tecnologia Assistiva, quando o objetivo final desejado é a utilização do próprio computador, para o que são necessárias determinadas ajudas técnicas que permitam ou facilitem esta tarefa. Por exemplo, adaptações de teclado, de mouse, software especiais etc.

As diferentes maneiras de utilização das TIC como Tecnologia Assistiva têm sido sistematizadas e classificadas das mais variadas formas, dependendo da ênfase que quer dar cada pesquisador. Optou-se, aqui, por utilizar uma classificação que divide essa utilização em quatro áreas (SANTAROSA, 1997):

- As TIC como sistemas auxiliares ou prótese para a comunicação: talvez esta seja a área onde as TIC tenham possibilitado avanços mais significativos. Em muitos casos o uso dessas tecnologias tem se constituído na única maneira pela qual diversas pessoas podem comunicar-se com o mundo exterior, podendo explicitar seus desejos e pensamentos. Essas tecnologias tem possibilitado a otimização na utilização de Sistemas Alternativos e Aumentativos de Comunicação (SAAC), com a informatização dos métodos tradicionais de comunicação alternativa, como os sistemas Bliss, PCS ou PIC, entre outros.

- As TIC utilizadas para controle do ambiente: as TIC, como Tecnologia Assistiva, também são utilizadas para controle do ambiente, possibilitando que a pessoa com comprometimento motor possa comandar remotamente aparelhos eletrodomésticos, acender e apagar luzes, abrir e fechar portas, enfim, ter um maior controle e independência nas atividades da vida diária.

- As TIC como ferramentas ou ambientes de aprendizagem: as dificuldades de muitas pessoas com necessidades educacionais especiais no seu processo de desenvolvimento e aprendizagem têm encontrado uma ajuda eficaz na utilização das TIC como ferramenta ou ambiente de aprendizagem. Pesquisas realizadas em diferentes instituições ${ }^{1}$ têm demonstrado a importância dessas tecnologias no processo de construção dos conhecimentos desses alunos.

- As TIC como meio de inserção no mundo do trabalho profissional: pessoas com grave comprometimento motor vêm podendo tornar-se cidadãs

\footnotetext{
${ }^{1}$ A exemplo do Núcleo de Informática da Educação Especial (NIEE) da Universidade Federal do Rio Grande do Sul (www.niee.ufrgs.br), do Núcleo de Informática Aplicada à Educação (NIED) da Universidade Estadual de Campinas (www.nied.unicamp.br) e do Programa Informática, Educação e Necessidades Especiais (InfoEsp) do Centro de Reabilitação e Prevenção de Deficiências (CRPD), unidade das Obras Sociais Irmã Dulce (www.infoesp.net/historic.htm).
} 
ativas e produtivas, em vários casos garantindo o seu sustento, através do uso das TIC.

Com certa frequência essas quatro áreas se relacionam entre si, podendo determinada pessoa estar utilizando as TIC com finalidades presentes em duas ou mais dessas áreas. É o caso, por exemplo, de uma pessoa com problemas de comunicação e linguagem que utiliza o computador como prótese de comunicação e, ao mesmo tempo, como caderno eletrônico ou em outras atividades de ensino e aprendizagem.

\section{UTILIZANDO A TECNOLOGIA ASSISTIVA EM AMBIENTE COMPUTACIONAL}

Busca-se apresentar aqui diferente recursos de Tecnologia Assistiva com a finalidade de possibilitar a interação, no computador, a pessoas com diferentes graus de comprometimento motor, sensorial e/ou de comunicação e linguagem. Ou seja, a utilização do computador por meio de Tecnologia Assistiva.

Para essa apresentação, é utilizada aqui a classificação proposta pelo Programa Informática, Educação e Necessidades Especiais (InfoEsp), ${ }^{2}$ das Obras Sociais Irmã Dulce, que sistematiza o estudo desses recursos propondo situá-los em três grupos:

- Adaptações físicas ou órteses: são todos os aparelhos ou adaptações fixadas e utilizadas no corpo do usuário e que facilitam a interação do mesmo com o computador.

- Adaptações de hardware: São todos os aparelhos ou adaptações presentes nos componentes físicos do computador, nos periféricos, ou mesmo, quando os próprios periféricos, em suas concepções e construção, são especiais e adaptados.

- Softwares especiais de acessibilidade: São os componentes lógicos das TIC quando construídos como Tecnologia Assistiva. Ou seja, são os programas especiais de computador que possibilitam ou facilitam a interação da pessoa com deficiência com a máquina.

Na seção seguinte, cada um desses três grupos é analisado e são apresentados alguns exemplos práticos.

\footnotetext{
${ }^{2}$ www.infoesp.net
} 


\section{ADAPTAÇÕES FÍSICAS OU ÓRTESES}

Quando se busca a postura correta para um usuário com deficiência física, em sua cadeira adaptada ou de rodas, utilizando almofadas, ou faixas para estabilização do tronco, ou velcro etc., antes do trabalho no computador, já se estará utilizando recursos ou adaptações físicas muitas vezes bem eficazes para auxiliar no processo de aprendizagem dessas pessoas. Uma postura correta é vital e é um pré-requisito para um trabalho eficiente no computador.

Algumas pessoas com sequelas de paralisia cerebral têm o tônus muscular flutuante (atetóide), fazendo com que o processo de digitação se torne lento e penoso, pela amplitude do movimento dos membros superiores na digitação. Um recurso que pode ser utilizado é a pulseira de pesos (Figuras 1 e 2) que ajuda a reduzir a amplitude do movimento causado pela flutuação no tônus, tornando mais rápida e eficiente a digitação. Os pesos na pulseira podem ser acrescentados ou diminuídos, em função do tamanho, idade e força do usuário.

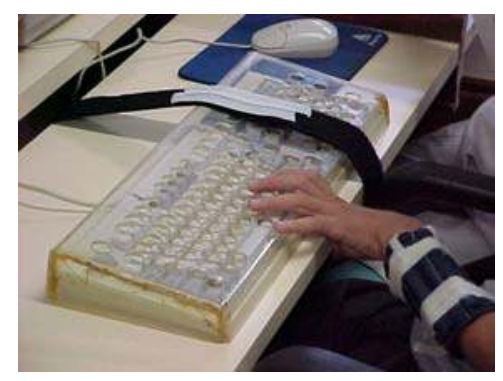

Figura 1 - Pulseira de pesos

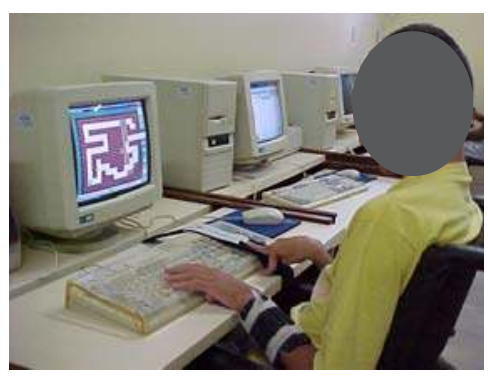

Figura 2 - Utilizando pulseira e teclado fixado

Outra órtese utilizada é o estabilizador de punho e abdutor de polegar com ponteira para digitação (Figuras 3 e 4), principalmente para pessoas com paralisia cerebral que dela necessitem.

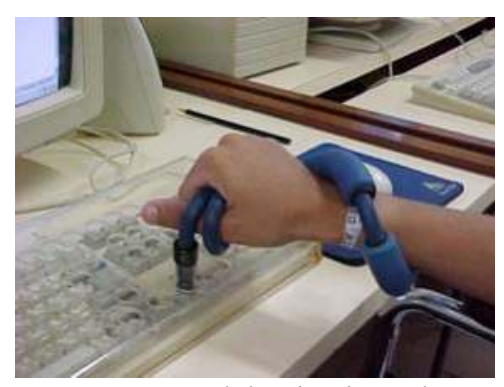

Figura 3 - Estabilizador de punho e abdutor de polegar

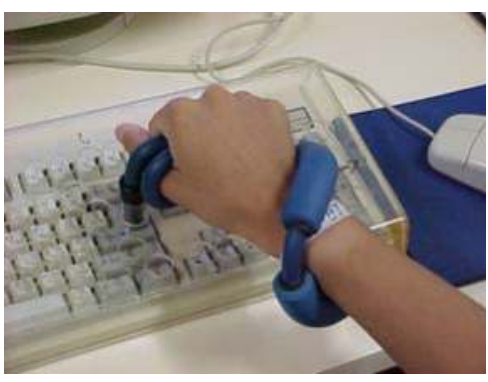

Figura 4 - Com ponteira para digitação 
Além dessas adaptações físicas e órteses, existem várias outras que também podem ser úteis, dependendo das necessidades específicas de cada pessoa, como os ponteiros de cabeça, ou hastes fixadas na boca ou queixo, quando existe o controle da cabeça, entre outras.

\section{ADAPTAÇÕES DE HARDWARE}

Quando são necessárias adaptações nos periféricos, na parte física do computador, as adaptações de hardware, antes de se buscar comprar acionadores especiais (switches) ou mesmo periféricos especiais, é fundamental procurar viabilizar, quando possível, soluções que utilizem os próprios "acionadores naturais” do computador, que são o teclado, o mouse e o microfone. Dessa forma, com muita frequência são encontradas soluções de baixíssimo custo, ou mesmo gratuitas, mas de alta funcionalidade.

Um dos recursos mais simples e eficientes como adaptação de hardware é a máscara de teclado ou colméia (Figuras 5 e 6). Trata-se de uma placa de plástico ou acrílico com um furo correspondente a cada tecla do teclado, que é fixada sobre o teclado, a uma pequena distância do mesmo, com a finalidade de evitar que o usuário com dificuldades de coordenação motora pressione, involuntariamente, mais de uma tecla ao mesmo tempo. Essa pessoa deverá procurar o furo correspondente à tecla que deseja pressionar.

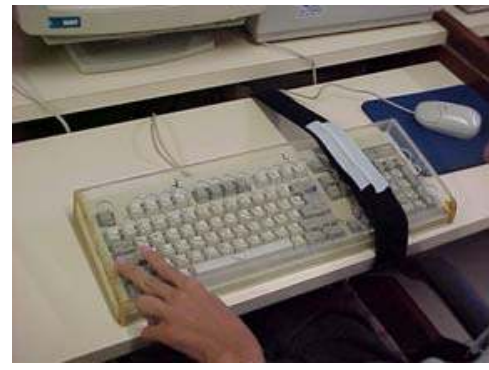

Figura 5 - Máscara de teclado encaixada no mesmo

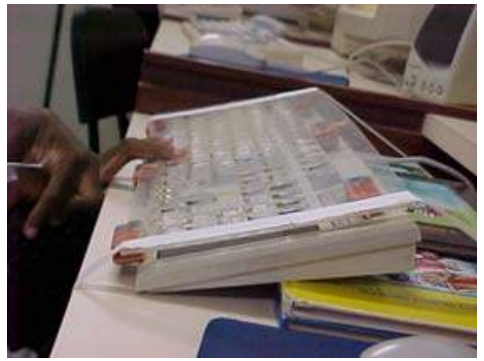

Figura 6 - Máscara de teclado sobreposta ao mesmo

Outras adaptações simples que podem ser utilizadas, dizem respeito ao próprio posicionamento do hardware (Figura 8). Por exemplo, determinado usuário que digita utilizando apenas uma mão, em certa etapa de seu trabalho e com determinado software que exigia que ele pressionasse duas teclas simultaneamente, descobriu ele mesmo que, se colocasse o teclado em seu colo na cadeira de rodas, ele poderia utilizar também a outra mão para segurar uma 
tecla (tecla Ctrl), enquanto pressionava a outra tecla com a outra mão. Já outro usuário está conseguindo agora utilizar o mouse para pequenos movimentos (utilização combinada com um simulador de teclado) com a finalidade de escrever no computador, colocando o mouse posicionado em suas pernas, sobre um livro de capa dura ou uma pequena tábua (Figura 7).

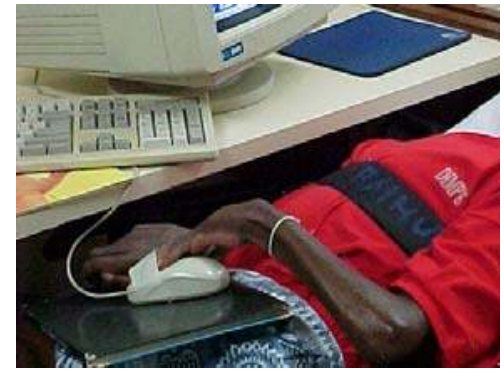

Figura 7 - Posicionamento do mouse no colo do usuário

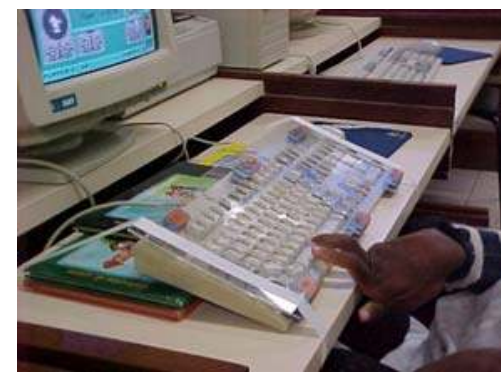

Figura 8 - Teclado com alteração na inclinação e fixado à mesa

Outra solução utilizada é reposicionar o teclado perto do chão para digitação com os pés, recurso utilizado por uma usuária que não consegue digitar com as mãos (Figura 9). E assim, diversas variações podem ser feitas no posicionamento dos periféricos para facilitar o trabalho da pessoa com deficiência, sempre, é claro, em função das necessidades específicas de cada uma.

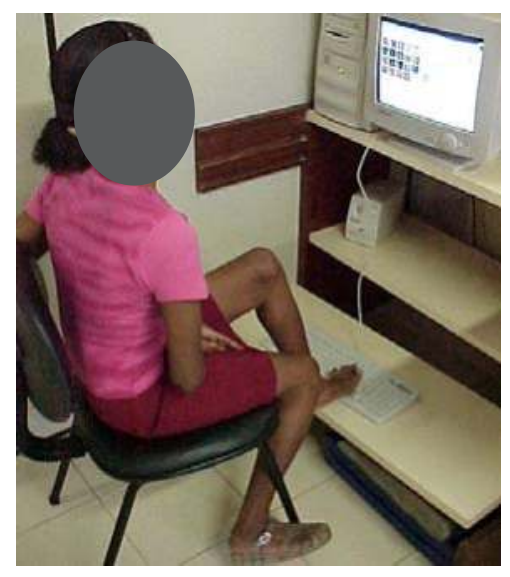

Figura 9 - Teclado reposicionado para digitação com o pé

As pesquisas desenvolvidas desde 1993 pelo Programa InfoEsp, em Salvador, têm revelado que a imensa maioria das necessidades dos seus alunos são resolvidas com recursos de baixo custo. Ou seja, é quebrada uma certa convic- 
ção generalizada, um certo tabu, de que falar de adaptações e Tecnologia Assistiva para o uso do computador por pessoas com deficiência, significa falar de aparelhos sofisticados e inacessíveis, e significa falar de altíssimos custos. As pesquisas e a prática têm desmentido essa convicção, e demonstrado que, na maioria dos casos, dificuldades e barreiras até bastante complexas podem ser atenuadas ou eliminadas com recursos de baixíssimo custo, mas de alta funcionalidade.

Além dessas adaptações de hardware apresentadas, existem muitas outras que podem ser encontradas em empresas especializadas, como acionadores especiais, mouses adaptados, teclados especiais, além de hardwares especiais como impressoras Braille, monitores com telas sensíveis ao toque etc. (São indicados endereços dos sites de alguns fornecedores ao final do texto).

\section{SOFTWARES ESPECIAIS DE ACESSIBILIDADE}

Alguns dos recursos mais úteis e mais facilmente disponíveis, mas muitas vezes ainda desconhecidos, são as "opções de acessibilidade" que já acompanham os sistemas operacionais. Através desses recursos, diversas modificações podem ser feitas nas configurações do computador, adaptando-o a diferentes necessidades dos alunos. Por exemplo, uma pessoa que, por dificuldades de coordenação motora, não consegue utilizar o mouse, mas pode digitar no teclado (o que ocorre com muita frequência), tem a solução de configurar o computador, através das opções de acessibilidade do Windows, para que a parte numérica à direita do teclado realize todos os mesmos comandos que podem ser realizados pelo mouse. Além do mouse, outras configurações podem ser feitas, como a das "teclas de aderência", a opção de "alto contraste na tela" para pessoas com baixa visão, e outras opções.

Outros softwares especiais de acessibilidade são os simuladores de teclado e os simuladores de mouse. Todas as opções do teclado ou as opções de comando e movimento do mouse, podem ser exibidas na tela e selecionadas, ou de forma direta, ou por meio de varredura automática que o programa realiza sobre todas as opções. $\mathrm{Na}$ internet existe, por exemplo, o site do técnico espanhol Jordi Lagares $^{3}$, no qual são disponibilizados para download diversos programas gratuitos por ele desenvolvidos. Trata-se de simuladores que podem ser operados de forma bem simples, além de serem programas muito "leves". Por meio desse simulador de teclado e do simulador de mouse, um aluno do Programa InfoEsp,

\footnotetext{
${ }^{3}$ www.lagares.org
} 
por exemplo, com 37 anos, pôde começar a trabalhar no computador, e, agora, expressa melhor todo o seu potencial cognitivo, iniciando a aprendizagem de leitura e escrita. Esse aluno, que é tetraplégico, só consegue utilizar o computador por meio desses simuladores, que lhe possibilitam transmitir seus comandos no computador somente por meio de sopros em um microfone. Isto lhe tem permitido, pela primeira vez na vida, escrever, desenhar, jogar e realizar diversas atividades que antes lhe eram impossíveis. Ou seja, por meio de simples sopros, horizontes totalmente novos se abriram para ele, possibilitando que sua inteligência, antes aprisionada em um corpo extremamente limitado, encontrasse novos canais de expressão e desenvolvimento (Figura 10).

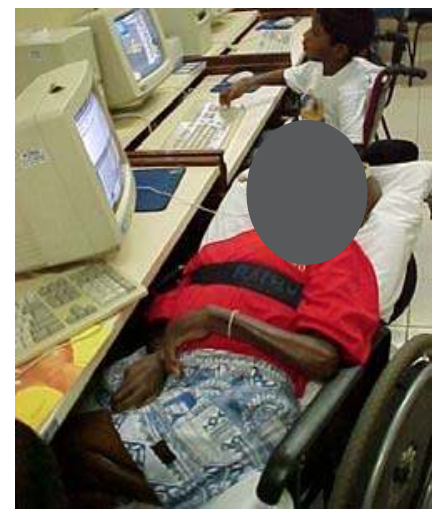

Figura 10 - Comandando o computador com sopros no microfone

Entretanto, algumas pessoas têm dificuldades ou na articulação ou na sincronicidade exigida, na emissão desses sons ou ruídos no microfone. A solução encontrada nesses casos foi acoplar ao microfone, com fitas adesivas, um desses brinquedos infantis de borracha, que produzem sons quando são pressionados. Dessa forma, o usuário pode comandar a varredura pressionando o brinquedo com a parte do corpo na qual exerça melhor controle (ou mão, ou pé, ou joelho, ou cabeça etc.). Com a pressão, o brinquedo emitirá o som no microfone, que acionará a varredura (Figuras 11 e 12).

Esses simuladores podem ser acionados não só por meio de sopros, mas também por pequenos ruídos ou pequenos movimentos voluntários feitos por diversas partes do corpo, e até mesmo por piscadas ou somente o movimento dos olhos, por meio de outros acionadores.

Outros recursos bem simples, porém bastante úteis, foram desenvolvidos pela equipe do Programa InfoEsp. Por exemplo, adaptações nos mouses co- 


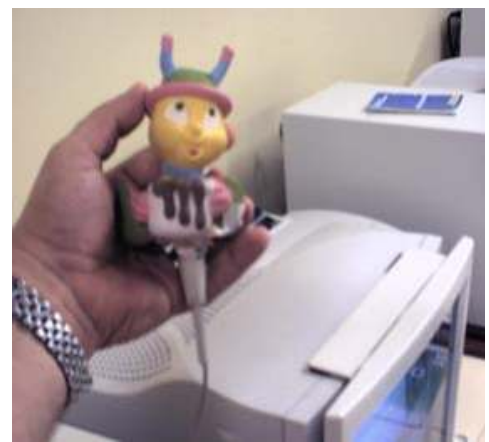

Figura 11 - Microfone com brinquedo de pressão acoplado

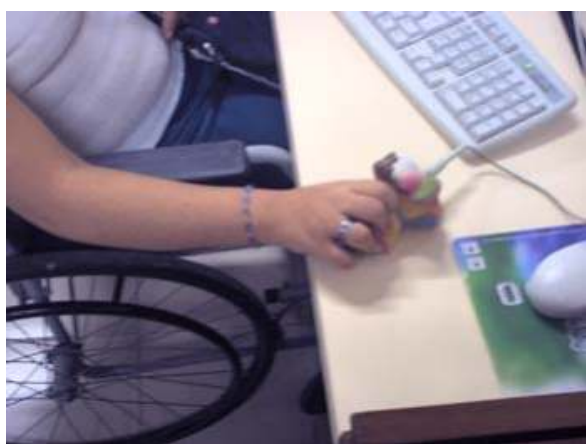

Figura 12 - Dispositivo em uso através de pressão com a mão

muns, como a instalação de plugs laterais nos mesmos, disponibilizando, através desses plugs, uma extensão do terminal do clique no botão esquerdo do mouse (Figura 13). Com frequência, um simples clique no botão esquerdo do mouse é suficiente para que o usuário possa desenvolver qualquer atividade no computador, comandando a varredura automática de um software, tal como escrever, desenhar, navegar na internet, mandar e-mails etc. Para que isso seja possível, também são desenvolvidos diferentes acionadores (switches) para serem conectados nesses plugs dos mouses e, assim, poder efetuar o comando correspondente ao clique no botão esquerdo, com a parte do corpo que a pessoa tiver o controle voluntário (braços, pernas, pés, cabeça etc.). Esses acionadores são construídos até mesmo com sucata de computador, aproveitando botões de liga/desliga dessas máquinas, às vezes para serem presos nos próprios dedos do aluno ou para acionamento com a cabeça (Figuras 14 e 15). São soluções simples, de custo praticamente nulo, porém de alta funcionalidade, e que constituem-se na diferença para algumas pessoas com deficiência, entre poder ou não utilizar o computador.

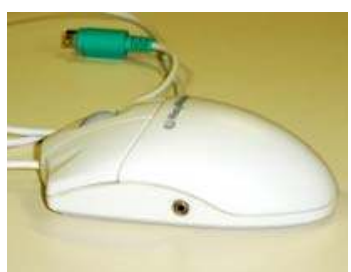

Figura 13 - Mouse adaptado com plug

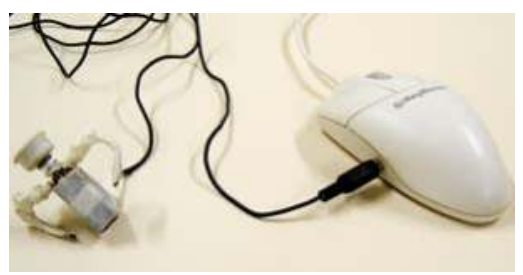

Figura14 - Acionador confeccionado com botão liga/desliga de computador

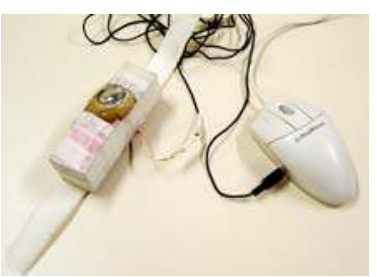

Figura 15 - Switches para acionamento com a cabeça, feito com botão grande de sucata 
Normalmente os softwares especiais de acessibilidade que funcionam com varredura automática aceitam o teclado, o mouse e/ou o microfone como acionadores (controladores) dessa varredura. Como exemplo, temos os softwares simuladores de teclado, os simuladores de mouse, e os softwares para a construção de pranchas de comunicação alternativa. O problema é que diversas pessoas com deficiência não conseguem utilizar nem o mouse, nem o teclado e nem o microfone, se estes não forem, de alguma forma, modificados ou adaptados. Dar um clique no botão esquerdo do mouse, por exemplo, pode ser uma tarefa muito difícil ou mesmo impossível para alguns usuários, em função ou das suas dificuldades de coordenação motora fina ou por causa de alterações anatômicas em seus membros superiores que impeçam a execução dessa tarefa. Outra sugestão aqui apresentada, possibilita ampliar a área de acionamento do botão esquerdo do mouse para uma superfície bem maior, com o mesmo efeito de um simples clique no botão. Trata-se de uma caixa comum de fita de vídeo VHS, dessas onde se guardam as fitas, dentro e no centro da qual é introduzido e fixado, com tira de velcro, um mouse qualquer. Na capa dessa caixa é colada uma borracha comum de apagar lápis, na altura exata onde se encontra o botão esquerdo do mouse. Essa capa da caixa deve ficar semifechada, podendo ser utilizadas pequenas faixas de velcro para mantê-la nessa posição. Colocando esse dispositivo na frente do usuário, quando ele pressionar qualquer lugar na capa da caixa, a borracha em relevo no interior da mesma entrará em contato com o botão esquerdo do mouse, e o efeito será o acionamento do clique nesse botão (Figuras 16, 17 e 18).

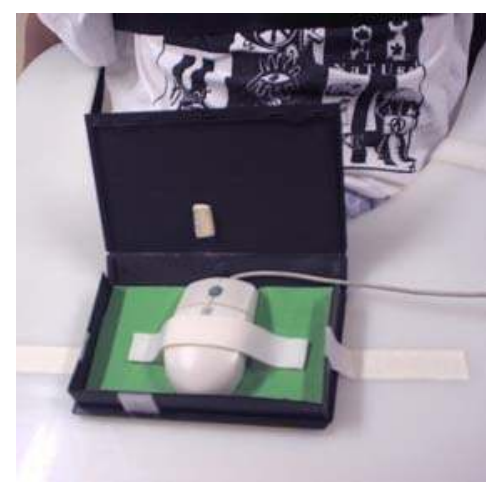

Foto 16 - Caixa de fita VHS com mouse no interior

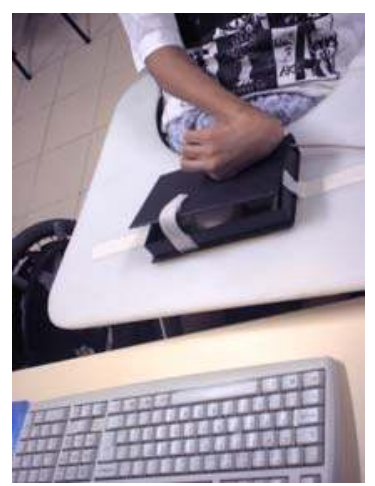

Foto 17 - Visão frontal do dispositivo em uso

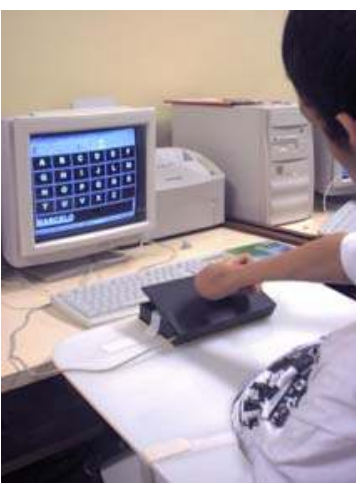

Foto 18 - Visão posterior do dispositivo 
Existem diversos sites na internet que disponibilizam gratuitamente outros simuladores e programas especiais de acessibilidade. Atualmente é possível controlar a seta do mouse apenas com o movimento do nariz, movimento este captado por uma webcam comum. Ou seja, uma pessoa tetraplégica, que mantenha o controle de cabeça, pode realizar qualquer atividade no computador apenas movimentando a cabeça, sem necessidade de nenhum equipamento especial e por meio de um software gratuito que pode ser baixado pela internet ${ }^{4}$.

Para pessoas com deficiência visual existem os softwares que "fazem o computador falar", os chamados leitores de tela. Existem diversos deles, tais como o DOSVOX, o Virtual Vision, o Bridge, Jaws e outros.

\section{CONCLUSÕES}

É importante ressaltar que as decisões sobre a Tecnologia Assistiva e os recursos de acessibilidade a serem utilizados devem partir de um estudo pormenorizado e individual, com cada pessoa com deficiência. Deve começar com uma análise detalhada e escuta aprofundada de suas necessidades, para, a partir daí, ir optando pelos recursos que melhor respondam a essas necessidades. Frequentemente é necessária também a escuta de outros profissionais, como terapeutas ocupacionais, fisioterapeutas ou fonoaudiólogos, antes da decisão sobre a melhor adaptação a ser utilizada.

Enfim, fica claro que o uso de todas essas possibilidades e recursos de Tecnologia Assistiva ajudam a deixar ainda mais evidente o enorme potencial de desenvolvimento e aprendizagem das pessoas com diferentes tipos de deficiência, o que, muitas vezes, não é tão transparente, tão facilmente perceptível, nas interações corriqueiras do dia-a-dia, na ausência desses recursos.

Disponibilizar a essas pessoas novos recursos de acessibilidade, novos ambientes, na verdade, uma "nova sociedade", que as inclua em seus projetos e possibilidades, não significa apenas propiciar o crescimento e a autorealização da pessoa com deficiência, mas, principalmente, é possibilitar a essa sociedade crescer, expandir-se, humanizar-se, através das riquezas de um maior e mais harmonioso convívio com as diferenças (GALVÃO FILHO, 2004).

\footnotetext{
${ }^{4}$ Buscar no Google: CameraMouse ou HeadDev.
} 


\section{REFERÊNCIAS}

BRASIL. Secretaria Especial dos Direitos Humanos. Coordenadoria Nacional para Integração da Pessoa Portadora de Deficiência. Ata da $7^{\text {a }}$ Reunião do Comitê de Ajudas Técnicas. Brasília, 2007. Disponível em: < http://www.mj.gov.br/sedh/ct/corde/dpdh/corde/Comitê de Ajudas Técnicas/Ata_VII_Reunião_do_Comite_de_Ajudas_Técnicas.doc $>$ Acesso em: 05 jan. 2008.

GALVÃO FILHO, T. A. Ambientes computacionais e telemáticos no desenvolvimento de projetos pedagógicos com alunos com paralisia cerebral. 2004. 178 f. Dissertação (Mestrado em Educação) - Faculdade de Educação, Universidade Federal da Bahia, Salvador, 2004.

LÉVY, P. Cibercultura. São Paulo: Editora 34, 1999.

SANTAROSA, L. M. C. "Escola virtual” para a educação especial: ambientes de aprendizagem telemáticos cooperativos como alternativa de desenvolvimento. Revista de Informática Educativa, Bogotá, v. 10, n. 1, p. 115-138, 1997. 


\section{SEXUALIDADE DE ADOLESCENTES PORTADORES DE DIFERENTES DEFICIÊNCIAS}

Fernanda Nunes Macedo Elaine Pereira Terrassi

\section{INTRODUÇÃO}

O tema escolhido é de grande relevância, uma vez que existem poucos livros e artigos que falem sobre a sexualidade dos diferentes tipos de deficiência. Como qualquer outro ser humano aqueles que são portadores de deficiência têm direito e necessidade de manter uma vida sexual. Porém, com esse tema tão pouco esclarecido surge o interesse em saber se os pais desses portadores conhecem as possibilidades e as restrições destes no que se refere à sexualidade.

Diferente da sexualidade dos adolescentes tidos como normais, a sexualidade dos deficientes não é um tema esclarecido nas salas de aula e nem é comumente tido como assunto de debates ou palestras. A intenção desse trabalho é de conhecer as diferenças e as semelhanças da vida sexual de portadores de diferentes deficiências através do relato dos pais.

A história da humanidade, assim como a história dos deficientes, varia de cultura para cultura, refletindo crenças, valores e ideologias que, materializadas em práticas sociais, estabelecem modos diferenciados de relacionamentos entre deficientes e não-deficientes (TOLEDO, 2000).

Numa perspectiva histórico-cultural, a família tende a imprimir, geralmente, aos portadores de deficiências, a ideia de que são incapazes, inábeis, inseguros e 
assim vão sendo "educados" para serem indefesos, dependentes e até considerados por alguns como assexuados e desinteressantes (TOLEDO, 2000).

O desejo e as descobertas da sexualidade são sinais de saúde. Mas quando o adolescente com deficiência começa a sair, conhecer pessoas, namorar e buscar uma vida sexual ativa, a família perde o controle sobre suas atividades, o que pode gerar medo de que ele seja rejeitado ou até mesmo abusado sexualmente. Com o intuito de proteger os filhos com deficiência, os pais costumam tratá-los como eternas crianças, negando assim o seu direito à sexualidade (TOLEDO, 2000).

A capacidade de manifestar e sentir amor constitui a essência básica da sexualidade. Demonstrações de ternura, simpatia e atração exprimem amor e afeto e revelam a natureza do indivíduo com ser sexuado (TOLEDO, 2000).

Em geral, pessoas com deficiência são privadas de orientação sexual e é essa desinformação geral que estimula o preconceito e restringe o direito dessas pessoas ao exercício de uma vida sexual livre, plena e satisfatória. Na adolescência, as pessoas com deficiência anseiam pelo estabelecimento de uma relação amorosa, afetiva e sexual, uma vez que estão expostas às mesmas normas sociais que as não-deficientes (BORTOLOZZI; ARANHA, 2005).

Portanto, o objetivo deste artigo é analisar as diferenças e semelhanças da sexualidade dos portadores de diferentes deficiências.

\section{A FAMÍLIA DE PORTADORES DE NECESSIDADES ESPECIAIS}

Inquestionavelmente, a entidade familiar tem uma importância significativa para a formação de todo e qualquer cidadão. Sendo o indivíduo portador de necessidade especial, essa importância ganha relevância, na medida em que o deficiente estrutura-se emocionalmente a partir de um bom relacionamento familiar, o que lhe possibilita o caminho para a integração social (BOLONHINI JUNIOR, 2004).

Para que possa existir uma boa relação da família com o portador de necessidade especial faz-se necessário que haja uma aceitação da deficiência por parte da família e por parte do próprio portador; conhecimento da família sobre os limites e potencialidades do deficiente e de sua possibilidade de integração social; conhecimento dos direitos do portador de necessidade especial para que o cidadão deficiente possa ser devidamente orientado, sobretudo, na infância e adolescência, e exigir o cumprimento das normas (BOLONHINI JUNIOR, 2004). 
Os não-deficientes têm dificuldades para compreender o que é ser deficiente. A cegueira, a surdez, ou a deficiência física podem ser simuladas, mas para os não-deficientes continua havendo uma armazenagem de memórias visuais, auditivas e motoras que oferecem um background rico de informações recuperáveis, não disponíveis para os deficientes (KIRK; GALLAGHER, 1996).

A maioria dos pais que têm filhos deficientes enfrenta duas crises principais. A primeira é um tipo de morte simbólica da criança que supostamente deveria ter nascido. Quando a mulher engravida alguns pais tendem a projetar como será o seu filho e o tipo de vida que este levará. Os pais querem que seus filhos sejam pessoas bem-sucedidas com uma segurança financeira e alguns podem ter esperanças que o filho os ajudará quando envelhecerem. Os pais que são encaminhados para um pediatra para ouvirem o diagnóstico de seus filhos como deficiente, deparam-se com a morte simbólica daquela criança com que sonharam, tendo frustrados assim os seus anseios e aspirações (KIRK; GALLAGHER, 1996).

A segunda crise envolve o problema de providenciar os cuidados diários para o filho. É frequentemente muito difícil alimentar, vestir e colocar na cama uma criança com paralisia cerebral, por exemplo (KIRK; GALLACHER, 1996).

"A expressão portador de necessidade especial abrange um grande número de situações que envolvem anomalias físicas, psíquicas, fisiológicas, muitas vezes de difícil caracterização." (BOLONHINI JUNIOR, 2004, p. 18). Ser portador de deficiência não implica necessariamente ter uma anomalia física visível, como a falta de um membro ou ter uma cegueira absoluta. Em muitos casos a deficiência é apenas caracterizada por uma perícia médica. (BOLONHINI JUNIOR, 2004).

É necessário ressaltar que existem diferenças entre os termos deficiência, deficiência permanente e incapacidade. Deficiência é toda perda ou anormalidade de uma estrutura ou função psicológica, fisiológica ou anatômica que gera incapacidade para o desempenho de atividade dentro do padrão considerado normal para o ser humano; Deficiência permanente é aquela que ocorreu ou se estabilizou durante um período de tempo suficiente para não permitir recuperação ou probabilidade de que se altere apesar de novos tratamentos cada vez mais eficientes; Incapacidade é uma redução acentuada e afetiva da capacidade de integração social, com necessidade de equipamentos, adaptações, recursos especiais para que a pessoa portadora de deficiência possa receber e transmitir informações essenciais para o bom desenvolvimento da sua vida social (BOLONHINI JUNIOR, 2004). 
Tendo em vista as diferenças sobre o termo deficiência, devem-se apontar as suas classificações. Estruturadas da seguinte forma. Conforme Bolonhini Junior (2004):

Deficiência Mental: é o nome dado à caracterização dos problemas que ocorrem no cérebro, e leva a um baixo rendimento cognitivo, mas que não afetam outras regiões ou áreas cerebrais.

Deficiência Visual: refere-se a uma situação irreversível de diminuição da resposta visual, em virtude de causas congênitas ou hereditárias, mesmo após tratamento clínico e/ou cirúrgico e uso de óculos convencionais. A diminuição da resposta visual pode ser leve, moderada, severa, profunda.

Deficiência Auditiva: é a perda parcial ou total da audição sonora, variando em graus e níveis; de 25 a 40 decibéis (db), surdez leve; de 41 a 55 db, surdez moderada; de 56 a $70 \mathrm{db}$, surdez acentuada; de 71 a $90 \mathrm{db}$, surdez severa; acima de $91 \mathrm{db}$, surdez profunda.

Deficiência Física: é a alteração completa ou parcial de um ou mais segmentos do corpo humano, acarretando o comprometimento da função física.

\section{SEXUALIDADE PARA OS PORTADORES DE NECESSIDADES ESPECIAIS}

Autores têm defendido que toda pessoa com deficiência é uma pessoa íntegra na sua sexualidade. Isto é, independentemente das possíveis limitações e complicações que possam ocorrer na manifestação sexual, ninguém torna-se assexuado em função de uma incapacidade física, sensorial ou mental (BLACKBURN, 2002; BUSCAGLIA, 1997 apud MAIA; ARANHA, 2005).

Para Chaú, Guimarães e Nunes (1985; 1995; 1987 apud MAIA; ARANHA, 2005, p. 103) entende-se por sexualidade;

[...] um conjunto de concepções e valores que envolvem a intencionalidade humana e a expressão afetiva de cunho social e histórico. A sexualidade envolve, então, uma amplitude de condutas humanas, para além de sua genitalidade e não deve ser entendida, exclusivamente, como sinônimo de sexo, relação sexual, orgasmo, órgãos sexuais, mas sim, na sua dimensão ampla e cultural que abrange diferentes aspectos como o amor, relacionamentos afetivos e sexuais, a sensualidade, o erotismo e o prazer, a expressão da identidade e dos papéis sexuais. 
Sendo assim, uma pessoa não pode ser considerada assexuada, pois a sexualidade é inerente ao ser social (BORTOLOZZI; ARANHA, 2005). Há duas décadas, a literatura vem apontando a sexualidade do deficiente como angelical, infantil ou como agressiva e incontrolável. Nesse sentido os deficientes são vistos sob duas premissas: os de anjos, quando a sexualidade é reprimida e não manifesta e os de feras, quando é expressa explícita e inadequadamente. Porém nesses dois casos há uma percepção distorcida sobre a vida afetiva e sexual dessas pessoas (PINHEIRO; LEAL, 2005).

Ao falar do tema sexualidade e deficiências, o mais importante é lembrar que ter vontades e desejos são coisas comuns a todo o ser humano, bem como suas necessidades de satisfação. A atividade sexual pode ser vista como uma forma de busca por segurança e proteção, ou seja, estabilidade e que a conduta sexual do indivíduo é o resultado da interação de aspectos biológicos, psicológicos e sociais (SCHLIEMANN, 2005).

É importante salientar ainda que a sexualidade envolve não apenas a conduta sexual do indivíduo, o ato sexual e a reprodução, mas também, tudo aquilo que remete às situações que nos proporcionam prazer, como os afetos, desejos, a nossa relação com o próprio corpo, as relações interpessoais, bem como o papel sexual que a pessoa exerce (SCHLIEMANN, 2005).

Para uma pessoa com deficiência, a descoberta do corpo e do prazer em manipulá-lo pode ocorrer tardiamente. Na puberdade quando o corpo já está desenvolvido, os deficientes podem manifestar inadequadamente as condutas sobre seu corpo e como manipulá-lo por falta de aprendizado, o que pode leválos à ansiedade e a sofrer repressões sociais. Com o avanço da idade a socialização e a interação com outras pessoas podem ficar ainda mais restrita e limitada ao ambiente familiar e da escola (MAIA; ARANHA, 2005).

Ao pensar-se que a sexualidade no deficiente não existe, proíbem-se manifestações normais e necessárias ao seu desenvolvimento, na medida em que é no processo interativo com os outros, particularmente com os pais e técnicos, com quem por vezes os deficientes passam a maior parte do seu dia, que se constrói o seu desenvolvimento psicossexual e que se definem os seus sentimentos, atitudes e valores face à sexualidade e ao relacionamento interpessoal em geral. Neste sentido, reprimir ou ignorar a sua expressão seria dificultar o seu crescimento e o seu desenvolvimento enquanto pessoas (PINHEIRO; LEAL, 2005).

Para que os deficientes tenham uma sexualidade adequada e prazerosa faz-se necessário à elaboração e a aplicação de estratégias educacionais eficazes, 
que proporcionem uma expressão saudável da sexualidade para que esta não seja encarada como diferente ou patológica (SCHLIEMANN, 2005).

\begin{abstract}
Em geral, pessoas com deficiências são privadas de orientação sexual e é essa desinformação geral que estimula o preconceito e restringe o direito dessas pessoas ao exercício de uma vida sexual livre, plena e satisfatória. Para que se atinjam os objetivos educacionais da orientação sexual é importante a utilização de recursos específicos e adaptados a diferentes limitações (ANDERSON; KITCHIN, 2000 apud MAIA; ARANHA, 2005, p. 104).
\end{abstract}

Toda criança com deficiência deve ser orientada para que quando chegue ao período adolescente, já tenha informações sobre seu corpo e sobre as mudanças que nele ocorrerão, pois isso pode ajudá-la a se envolver, na idade adulta, em relacionamentos saudáveis. A orientação dos pais e da escola é extremamente importante para garantir o treinamento de habilidades sociais e sexuais (PINHEIRO; LEAL, 2005).

\title{
CONCLUSÃO
}

O objetivo deste artigo foi analisar as diferenças e semelhanças da sexualidade dos portadores de diferentes deficiências. Como já fora citado na fundamentação teórica a entidade familiar tem uma importância significativa para a formação de todo e qualquer cidadão. Sendo o indivíduo portador de necessidade especial, essa importância ganha relevância, na medida em que o deficiente estrutura-se emocionalmente a partir de um bom relacionamento familiar, o que lhe possibilita o caminho para a integração social.

Toda pessoa com deficiência é uma pessoa íntegra na sua sexualidade. É necessário que os pais de portadores de necessidades especiais não rotulem seus filhos como incapazes ou imaturos. Com uma equipe profissional adequada fazse necessário à elaboração de estratégias educacionais eficazes que ajudem na expressão sexual de cada deficiente.

Este assunto é pouco debatido nos consultórios médicos, nas casas de apoio, nas escolas, nas instituições e nas famílias. A sexualidade dos portadores de necessidades especiais precisa ser mais discutida para que assim os pais tenham maiores orientações e informações sobre a sexualidade humana, esclarecendo e orientando seus filhos de maneira saudável. 


\section{REFERÊNCIAS}

ANDERSON, P.; KITCHIN, R. Disability, space and sexua-lity: acess to family planning services. Social Science \& Medicine, Oxford, v. 51, n. 8, p. 1163-1173, oct. 2000. Apud MAIA; ARANHA, 2005.

BLACK-BURN, M. Sexuality \& Disability. Oxford: Butterworth Heinemann, 2002. Apud MAIA; ARANHA, 2005.

BOLONHINI JUNIOR, Roberto. Portadores de necessidades especiais: as principais prerrogativas e a legislação brasileira. São Paulo: Editora Arx, 2004.

BUSCAGLIA, L. Os deficientes e seus pais: um desafio ao aconselhamento. 3. ed. Rio de Janeiro: Record, 1997. Apud MAIA; ARANHA, 2005.

CHAUÍ, M. Repressão sexual: essa nossa (des)conhecida. São Paulo: Brasiliense, 1985. Apud MAIA; ARANHA, 2005.

MAIA, A. C.; ARANHA, M. S. Relatos de professores sobre manifestações sexuais de alunos com deficiência no contexto escolar. Interação em Psicologia, São Paulo, v. 9, n. 1, p. 103 116, 2005. Disponível em: < http://ojs.c3sl.ufpr.br/ojs2/index.php/psicologia/article/view/ 3290/2634>. Acesso em: 20 out. 2009.

GUIMARÃES, I. Educação sexual na escola: mito e realidade. Campinas: Mercado das Letras, 1995. Apud MAIA; ARANHA, 2005.

KIRK, S.; GALLAGHER, J. Educação da criança excepcional. São Paulo: Martins Fontes, 1996.

NUNES, C. A. Desvendando a sexualidade. Campinas: Papirus, 1987. Apud MAIA; ARANHA, 2005.

PINHEIRO, A. L.; LEAL, I. Sexualidade na deficiência mental. Revista Integrar, 2005.

SCHLIEMANN, A. P. Sexualidade - adolescência - deficiência mental: um desafio a pensar. In: SIMPÓSIO INTERNACIONAL DO ADOLESCENTE, 2., 2005. São Paulo.

Proceddings online... São Paulo: Faculdade de Psicologia da PUC/SP - Departamento de Psicologia do Desenvolvimento, 2005. Disponível em: < http://www.proceedings.scielo.br/ scielo.php?pid=MSC0000000082005000200074\&script $=$ sci_arttext $>$. Acesso em: 20 out. 2009.

TOLEDO, M. A. Deficiência visual: a trajetória dos preconceitos - ontem e hoje. São Paulo: [S.n.], 2000. 



\title{
CORPO E ALTERIDADE NOS COMPLEXOS DE (IN)EXCLUSÃO
}

\author{
Fabio Zoboli \\ Renato Izidoro da Silva \\ Miguel Angel Garcia Bordas
}

\section{O CORPO NOSSO DE CADA DIA}

O corpo sempre se apresentou como objeto problemático à construção dos saberes humanos tanto em termos gnosiológicos, como em termos epistemológicos. Oscilando entre sua materialidade e sua significância, o corpo é em grande parte um produto dos complexos sociais e culturais em que está imerso.

Partindo dessa lógica, Mondin (2003) menciona que o corpo humano pode variar entre uma concepção científica que pensa o corpo-coisa, o corpo objeto, aquilo que os alemães chamam de Korper e a consideração fenomenológica que estuda o próprio corpo enquanto lugar de sentidos e significações experimentados e vividos, que para os alemães se trata do Leib. Enquanto este atua como agente de linguagem na medida em que significa a matéria por meio de suas potencialidades de expressão conforme suas estruturas motrizes que se revertem em signos e símbolos determinados por significados. O primeiro consiste em ser um cadáver a ser significado pelo segundo.

No que concerne aos fenômenos ou conceitos de inclusão e exclusão tendo o corpo como fator permeando esses jogos, nossa problemática pode ser demonstrada historicamente de acordo com Kuri , Hargreaves e Valença (2000), quando ensinam que em alguns países as mulheres prostitutas sofriam a ação de 
signos e símbolos por serem obrigadas a usar cores distintivas como o vermelho, para não serem confundidas com outras mulheres. Em outro âmbito, a medicina na Idade Média, demarcava os leprosos que só podiam andar com sinos presos ao corpo, de forma a anunciarem sua presença mesmo à distância. Em alguns casos até o século passado as pessoas que haviam cometido delitos considerados graves eram, algumas vezes, marcados com ferro em brasa, para carregarem para sempre a marca de sua culpa. Na Europa no século XVII, as prostitutas que eram pegas com soldados podiam ter as orelhas ou a ponta do nariz cortada. Em países do Oriente, até hoje cortam-se a mão direita dos ladrões.

Frente a este estigma de demarcação corporal como forma de (in)exclusão Todorov (2003), distingue três eixos que situam a problemática da alteridade nesses casos. Primeiramente, no plano judicativo e axiológico, entra em questão a bondade ou a maldade do outro, o gostar ou não gostar, se é igual ou se é inferior. Em segundo, explicita um plano praxeológico, em que a alteridade varia entre as dúvidas de adotar os valores do outro ou impor a própria imagem, contando ainda com a opção da indiferença. Havendo por último, o plano epistemológico, no qual gradativamente, por meio da convivência - pacífica ou não - o outro vai se desvendando como um objeto conhecido: seus hábitos, valores, interesses etc. Tal episteme pode servir positiva ou negativamente aos dois primeiros eixos. Sendo que, nos três planos temos como elemento determinante, o corpo do outro, o nosso próprio e de algum terceiro que vivenciam complexos de inclusão e exclusão.

Não são raros os sujeitos que se emvergonham de sua autoimagem corporal. Bem como não são poucos aqueles que envergonham o outro ao julgar a aparência do outro. O trato destinado ao obeso, baixo, estrábico, manco, portador de deficiência em geral, negro, branco e tantos outros que estão na ordem do dia, remonta uma certa antropologia evolucionista e liberal pertencente à segunda metade do século XIX (BOAS, 2004), que pode ser enquadrada no plano negativo dos três eixos da alteridade, que propõe Todorov (2003), tal como citamos acima. Lugar comum na antropologia hodierna, a crítica da noção evolucionista desloca o corpo do lugar dos signos de superioridade e inferioridade das raças e dos povos, para o lugar da diferença.

Martins (1954) lembra que a antropologia darwinista centrou suas interpretações acerca do outro - outros povos - nos caracteres anatômicos: estatura, forma e capacidade dos crânios, estrutura dos cabelos e a cor da pele como parâmetros para organizar um sistema científico explicativo das raças naturais, que justificasse o escravismo e os genocídios. 
Entretanto, questionada essa perspectiva pela antropologia do século XX com Lévy-Bruhl, Boas, Mauss e Lévy-Strauss, a lógica darwinista se mantém organizando a alteridade no campo endógeno das sociedades modernas e ocidentais. Conquistado pelo mito do "bom selvagem" estimulado pelo pensamento de Rousseau, o homem moderno e urbano passa a enxergar negatividades nas diferenças existentes em sua própria sociedade. O negro já integrado e os indígenas já considerados brasileiros, misturados e agentes da paradoxal vida moderna que luta contra os medievalismos, passam a ser admirados no plano teórico de sua ancestralidade diacrônica, mas subsumidos nas diferenças e desigualdades sincrônicas dinamizadas pela lógica dos grandes centros, sempre divididos em centro e periferias, condomínios e favelas, clubes privados e praças públicas, negros e brancos, pobres e ricos.

Em outros termos, o darwinismo social é uma extensão da história natural dos homens, a qual a antropologia de Boas (2004) rechaçou cientificamente. As relações sociais são naturalizadas de modo a configurar o mito do "bom selvagem" corrompido pela vida em sociedade, no interior da urbanidade como sendo uma "selva de pedra". Os edifícios são as árvores e os andares mais altos são as copas onde se encontram os "frutos mais ricos". O nível da rua fica reservado aos animais rasteiros que enfrentam a irregularidades do terreno, derivadas de uma má administração pública que não cuida dos passeios e do asfalto. Os homens-macacos que ainda necessitam utilizar a rua para trafegar, mesmo que no interior de seus carros de luxo, não se comparam àqueles que conseguiram a liberdade dos pássaros, por meio de aviões, jatinhos e helicópteros. Ora, é assim que se opera o eixo judicativo da antropologia etnocêntrica que avalia o outro pelo grau de suas tecnologias, isto é, de suas extensões corpóreas que ajudam o homem em sua inclinação à transcendência física (SÉRGIO, 1999).

Entretanto, a transcendência tecnológica tem seu preço negativo. $\mathrm{Na}$ economia de energia corpórea se originou um superávit primário do corpo primitivo, gerando um déficit na qualidade e potencialidades do corpo enquanto tecnologia do espírito por excelência. Ou seja, no que tange a questão da obesidade, à qual foi gerada como resultado do darwinismo social norte americano, é comum observar garotos obesos se queixando nas aulas de educação física tradicional, mas satisfeitos pela nova educação física que preza pela matéria estática em prol da transcendência midiática que leva virtualmente o corpo às distâncias mais longínquas.

Por um lado é o físico atlético e ginástico com alto desenvolvimento técnico e estético que o método natural de Herbert (2003 apud SOARES, 2003) 
observa com deslumbre entre os povos primitivos, segundo a antropologia rousseana do mito do "bom selvagem". Por outro, a civilidade desses últimos é julgada com respeito às tecnologias que podem diminuir os esforços físicos dos homens: um machado de pedra diante de um machado de ferro enquanto uma tecnologia primitiva da moto-serra determina o olhar do homem moderno sobre os selvagens, da mesma forma que já no interior da modernidade a posse do martelo e do prego em face da posse da furadeira elétrica e do parafuso, pode determinar os limites entre o popular e o burguês.

De tal modo, não podemos esquecer Marcel Mauss (2003) quando, de certa forma, expõe a complicação em expor a distância entre um "martelo de pedra" e uma "furadeira elétrica" como simples diferença, em face da antropologia evolucionista e do darwinismo social que encara o mesmo fato como critério de inferioridade e superioridade, respectivamente. Nesse sentido, refletindo sobre uma educação moderna, percebe-se que os corpos que se desviam dos padrões de uma normalidade utilitária não interessam para aquém das paixões dos antropólogos: a técnica e a tecnologia são dados primitivos de uma evolução.

\section{O "MEU” CORPO DO “OUTRO”: O “CORPO NOSSO”}

O modelo elitista - darwinista e evolucionista - de corpo acima citado atinge seu cume na contemporaneidade com as mensagens do mass media. Segundo os estudos de Inkeles (1981, p. 141), a "ampla difusão dos meios de comunicação de massa é um dos melhores indicadores de desenvolvimento econômico avançado". De outro modo, mesmo que infinitamente discutível "muita gente acredita que se pode facilmente mobilizar um grande volume de evidência para provar que, com um aumento da exposição aos meios de comunicação de massa, os homens podem se tornar mais modernos." Principalmente, se avaliarmos os chamados programas televisivos, tal como o Big Brother Brasil, ${ }^{1}$ onde os participantes são selecionados segundo suas qualidade referentes a um padrão estético que implica na retomada e sustentação do darwinismo natural e social, pois seus corpos expressam as qualidades da força e da destreza, acabando por estimular o público, não só a um ideário de beleza, mas também à tecnicidade e à sexualidade.

\footnotetext{
${ }^{1} \mathrm{O}$ Big Brother Brasil é um programa televisivo apresentado pela rede globo onde um grupo de pessoas - de igual número em ambos os sexos- são confinados em uma casa e vigiados por câmaras 24 horas por dia. A cada semana, sob toda uma regulamentação do jogo um sujeito é eliminado da casa.
} 
O corpo, portanto, se apresenta desde sempre como um dado cultural já estabelecido tal como o interpretante dinâmico da teoria semiótica peirceana. Nesse sentido, o corpo é o verdadeiro intérprete das telenovelas e dos reality shows, onde dialogam, convergem e divergem inúmeros outros signos. Por exemplo, muitas vezes a personagem do homem belo - galã - tenta unir em sua corporeidade um complexo de signos sociais, culturais, políticos e econômicos expressos em forma de gestos, falas, posicionamentos ante aos outros, a si mesmo e a situações diversas, sempre tentando convergir partes contraditórias de um corpo quase esquizofrênico que se anula como refém para seguir as ordens de um plano diretor que constitui a trama novelesca cujo objetivo é imprimir algumas insígnias nos telespectadores "sem" ancestralidade, acerca do que seja o ideal do "bem viver".

Em pano de fundo ou em primeiro plano, sobre a constituição do sujeito, Lévy (1996, p. 57) menciona a existência de comunidades vivas que "estão sempre presentes no menor de nossos pensamentos, quer elas forneçam interlocutores, instrumentos intelectuais ou objetos de reflexão." Sendo mais radicais nessa reflexão, a depender do grau de contato que cada sujeito estabelece com os signos do mass media, maior é a chance de ele não pensar coletivamente, mas certamente da comunidade pensar em seu interior. Consiste essa noção na constituição do Grande Outro, tal como ensina Lacan (1985).

Em publicação anterior Silva (2007), discutiu os imbricamentos entre a constituição do sujeito em seu complexo mapeado conceitualmente pela noção psicanalítica de Outro e de Ideal-do-Eu. Ligeiramente, para logo seguirmos com os propósitos deste texto, importa saber que o sujeito é a própria trama ou o próprio drama vivido na primitividade da matéria corpórea onde o real se inscreve e a realidade emerge, em termos de demanda e desejo do Outro. O Ideal-do-Eu está para a demanda, assim como o desejo está para a sublimação. O primeiro, na menção de Freud (1976, p. 101) implica a repressão e o segundo uma saída econômica para atender às demandas sem repressão.

A saída via Ideal-do-Eu, ou seja, por meio da demanda do Outro, significa sacrificar a matéria e o Eu no cumprimento de ordem impossível, cujas insígnias nunca são apresentadas de modo completo, por sempre lhe faltar algo para atingir a perfeição. Nesse ponto, tudo que está fora da demanda se torna proibido, pois sua dedicação ao Outro não pode ser traída, de modo a se abrir a outros objetos tramados que possam lhe significar, abrindo-lhes os sentidos.

Desta forma, cabe repensar o corpo como fator de exclusão e de inclusão, na medida em que, antropológica e historicamente, ele sempre se constituiu 
enquanto um complexo de imagens - insígnias - que são utilizadas pelos mecanismos de poder e de ideologias sócio-culturais-econômicas, como um meio de se capturar o sujeito para aprisioná-lo e controlá-lo em alguma posição rígida e imutável, estabelecendo uma - suposta - essência em sua aparência material. Como Freud (1976, p. 41) alertou na construção de seu paradigma: "O ego [eu] é antes de mais nada (sic) um ego corporal, não apenas um ser de superfície mas ele próprio a projeção de uma superfície." Em última instância, o eu é "derivado de sensações corporais, principalmente das que nascem da superfície do corpo ao lado do fato [...] de representar a superfície do aparelho mental."

Sob essa ótica, ao refletirmos sobre os processos de (in)exclusão, vislumbramos a constituição de estigmas capazes de significar o outro para o eu ou sujeito, tal como Hitler fez com os judeus, ao obrigar que estes vestissem faixas em seus braços. Assim, podemos identificar aspectos que estruturam relações de poder na medida em que atribuem valores negativos, positivos e indiferentes às diferenças e desigualdades, dimensionando-as simbolicamente como inferior, superior ou indolente. Foucault (2001) menciona que o corpo passa assim a ser dominado por inúmeros signos que exercem sobre ele relações de poder em forma de coerção, controle e cuidado: formatando, corrigindo e imprimindo certo número de qualidades a serem seguidas e até mesmo desejadas.

Lembrando que o corpo nos textos foucaultianos aparece sob três perspectivas básicas: a primeira ao nível das coerções físicas, a segunda no plano do controle discursivo e a terceira vinculada ao discurso social do cuidado que retroage sobre a noção do cuidar de si mesmo, onde a coerção, o controle e o cuidado agem desde o interior. Em temos hodiernos, contando com o princípio da descontinuidade histórica ao qual Foucault (2004) sempre se refere, não mais devemos fixar a figura do líder, mas sua pulverização nos veículos discursivos de massa que tomaram seu lugar, de modo que a questão do Ideal-do-Eu se torna cada vez mais eficiente e necessária, não só como instância psíquica ontológica particular, mas principalmente no que concerne aos agenciamentos de poder de um certo pensamento coletivo que se pretende hegemônico.

Hoje podemos pensar, em grande sentido, que o corpo se transformou no objeto do mercado capitalista, já que os fundamentos discursivos desse aplicam-se na exigência da experimentação. Ao mesmo tempo em que o corpo experimenta uma roupa, um perfume, uma maquiagem... enfim, a configuração material de uma imagem que implica um ideal, ele está sendo experimentado pelo produto e pelo sistema que produz o mesmo. Para Bastide (1979, p. 52), no capitalismo, existe a regra da aculturação planejada que continua sendo 
a necessidade de "prever os efeitos das novidades introduzidas tanto na psique dos indivíduos quanto na coesão do grupo." Lembrando novamente os três eixos de Todorov (2003, p. 270), só que agora pensando de modo invertido.

No plano epistemológico, os objetos de consumo aliados a inúmeros discursos, produzem efeitos nos sujeitos, que se transformam em saberes acerca das causas e das razões que nos determinam enquanto sujeitos históricos, antropológicos e sociais. Atrelado a isso se manifesta o plano praxeológico, em que a alteridade varia entre as dúvidas de adotar os estigmas que vêm do outro ou buscar a produção - subversão - da própria imagem, contando ainda com a opção da indiferença. O eixo judicativo se desloca de suas possibilidades maniqueístas, para correr sobre os trilhos das "leis" do gosto: gostar ou não gostar.

Refletindo sobre os complexos simbólicos que esses processos podem envolver, Bourdieu (1998) esclarece que os julgamentos que pretendem aplicar-se à pessoa em seu todo levam em conta não somente a aparência física propriamente dita: para nós, o Leib do Korper. Mas se considera sobretudo, o corpo socialmente vestido e modelado por meio de adereços como roupas, cosméticas e as maneiras de conduta, construindo um certo saber através das taxionomias sociais, portanto lido como sinal da qualidade e do valor da pessoa, que podem se reverter em mecanismos ou símbolos de exclusão e inclusão em determinados grupos restritos e até mesmo em âmbitos mais gerais da sociedade globalizada.

O béxis ${ }^{2}$ corporal é assim, o suporte principal de um julgamento de classe que se ignora como tal, quem sabe por que justamente os mecanismos coercitivos dos quais falou Michel Foucault em sua teoria sobre a sociedade disciplinar, foram substituídos por operações simbólicas, evitando o que Bastide (1979) chamou de aculturação forçada e destrutiva.

\section{SIGNOS CORPORAIS DA (IN)EXCLUSÃO: ABORDANDO A QUESTÃO DA DEFICIÊNCIA}

Nosso pensamento traçou até o momento, uma forma que transcende os aspectos anátomo-fisiológicos do corpo, para tentar compreendê-lo em sua dimensão vivida nos planos antropológico, histórico, social e psicológico.

${ }^{2}$ A béxis indica uma disposição incorporada - quase postural de um saber socializado.

Héxis é o equivalente grego de habitus. 
Nesse sentido, a antropologia leva em consideração os dados da psicologia, por perceber aí uma relação de contiguidade entre mente - ou sistema de pensamento - e corpo, tanto o Korper quanto o Leib. O corpo que compra a imagem da beleza impressa no corpo do outro ou de vários pequenos outros que ocupam, cada qual, de modo figurado alguma qualidade do líder. O belo passa a ter valor simbólico no mercado material. A idealização do belo é materializada e os corpos que dela se aproximam gozam de maior valor mercadológico enquanto objetos, isto é, corpos sem mão-de-obra. O corpo objeto sucumbe o corpo sujeito ou o exalta quando representado pelo eu narciso, e a moral ou vergonha corporal muitas vezes "desnuda" frente o mercado, ou senão se transforma em mais um signo fetichizado a ser experimentado no corpo do outro, por meio de produções fantasiosas de uma certa casta perversão.

A pergunta que agora se apresenta de modo incômodo, é como ficamos diante daqueles que historicamente e socialmente vêm sendo estigmatizados pelos signos de exclusão? Em termos mais diretos, imersos no atual sistema capitalista, cujo produto mais comercializado; direta ou indiretamente, é o corpo, conforme as insígnias do etnocentrismo europeu, ou seja, branco e "perfeito", qual nossa perspectiva sobre o negro, o analfabeto, o pobre, o deficiente etc.?

Hoje já se pode afirmar que em nenhuma outra época o sujeito em condição de deficiência foi alvo de tantas pesquisas e estudos, bem como nunca se esteve tão preocupado em inserir tais pessoas com tamanho empenho nas relações sociais. Isso não significa dizer que se chegou ao auge e que tudo já está conquistado; pelo contrário, sabe-se que ainda muitas coisas precisam ser aperfeiçoadas e modificadas.

Porém, aqui queremos alertar que muito do que acontece em relação aos complexos formados pela (in)exclusão, por exemplo, dos portadores de deficiência, se deve ao fato da episteme de cisão corpo/mente. Quando se fala em portadores de deficiência, o que se observa segundo Marques (2001) é uma forte tendência em se avaliar a deficiência somente sob o prisma biológico, passando o portador a ser tratado como um "doente": uma pessoa fragilizada, sempre necessitada de assistência, por isso, digna de pena. Assim procedendo, as pessoas ditas "normais" reduzem os significados de normalidade e de adaptação para os padrões estéticos e os de produtividade - capitalistas - do corpo.

Para Sérgio (2003), continuamos deficientes numa sociedade corroída pela divisão estrutural entre classes. Não há pessoas deficientes, há pessoas diferentes. De educação especial, diz o autor, é bem possível que todos nós precisemos. 
Afinal de contas, a mercantilização dos indivíduos, como produto da ampliação da utilização de categorias econômicas na atual conjuntura social, coloca o corpo como uma mercadoria que possui os atributos e as possibilidades de quaisquer dos bens produzidos na sociedade. Aqui vale a reflexão: na atual conjuntura neoliberal - fundada no lucro e pautada pelas leis de competição e mercado que geram seleção e exclusão - que valor possui um corpo em condição de deficiência no mercado corporal simbólico?

A inserção dos portadores de deficiência dentro da sociedade e suas relações é um tema que vem sendo merecedor de profundas análises por parte das mais variadas áreas de estudo, haja vista que ao longo da história o homem sempre apresentou dificuldades nas relações com o diferente, nas relações que envolvem aqueles que se afastam dos padrões de normalidade - padrões estes estabelecidos pela própria sociedade.

Quando se fala em inclusão social - seja lá qual for seu segmento - é na unicidade e diferença que precisam estar fundadas as nossas bases de ação. Afinal, o homem normal, na menção de Carvalho (1999), é um homem hipotético - Ideal-do-Eu - estabelecido discursivamente com base na média aritmética de todos os homens que à partida são diferentes. Sendo que, de portador de alguma deficiência - diferença - traz algum estigma físico construído a partir da história, estigma esse que lhe nega, muitas vezes, a possibilidade de ter acesso a diversas relações de cunho social. Assim, a grande maioria das pessoas em condição de deficiência se limita a um mundo a parte não porque seja incapaz de se relacionar com os outros, mas porque as relações sociais usurpam deles esse direito. A inclusão nos mais variados segmentos sociais é tão importante para as pessoas portadoras de deficiência quanto para as pessoas ditas "normais" ou "ideais".

Sob esta óptica, a inclusão das pessoas em condição de deficiência não se trata apenas de aceitar um diferente em nosso meio. Esta, segundo Forest e Pearpoint (1997), é a menor parte do quebra-cabeça. Trata-se de como nós lidamos com a diversidade, a diferença, quando engessados pela nossa moralidade. Inclusão não significa dizer que somos todos iguais. Mas, pretender uma celebração de nossa diversidade e diferença com respeito e gratidão ao outro, que por ser diferente de mim, me torno diferente dele, por princípio. Não sendo à toa, quanto mais diversidade, mais rica a nossa capacidade de criar novas formas de ver e de ser olno mundo, reconstruindo nossos corações por meio de instrumentos que possibilitem a sobrevivência da humanidade como uma família global. 
O olhar o diferente depende da posição relativa daquele que percebe e daquele que é percebido, e do grau em que os esquemas de percepção e apreciação postos em ação são conhecidos e reconhecidos pelos envolvidos. Uma das funções sociais da escola - e da educação de modo geral - neste sentido, é a reflexão e a (re)significação das lentes que focam os olhares sobre os diferentes e as diferenças.

\section{REFERÊNCIAS}

BASTIDE, Roger. Antropologia aplicada. São Paulo: Editora Perspectiva, 1979.

BOAS, Frans. Antropologia cultural. Tradução Celso Castro. Rio de Janeiro: Jorge Zahar, 2004.

BOURDIEU, Pierre. Escritos de Educação. In: NOGUEIRA, Mendes Afranio; CATANI, A. (Org.). As categorias do juízo professoral. 3. ed. Petrópolis: Vozes, 1998. p. 185-216.

CARVALHO, Jorge Vilela C. O acto diferente e seu significado. In: SÉRGIO, Manoel. (Org.). O sentido e a acção. Lisboa: Instituto Piaget, 1999. (Coleção: Epistemologia e sociedade)

FOREST, Marsch; PEARPOINT, Jack. Inclusão: um panorama maior. In: MANTOAN, Maria Teresa Egler, A integração de pessoas com deficiência: contribuições para uma reflexão sobre o tema. São Paulo: Memnon, 1997. p. 137-41.

FOUCAULT, Michel. Vigiar e punir: história da violência nas prisões. 22. ed. Petrópolis: Vozes, 2001.

A ordem do discurso: aula inaugural no Collège de France, pronunciada em 2 de dezembro de 1970. Tradução de Laura Fraga de Almeida Sampaio. São Paulo: Edições Loyola, 2004.

FREUD, Sigmund. Psicologia de grupo e análise do eu. In: completas. Rio de Janeiro: Imago, 1976. v. 18. Edição standard brasileira. O eu e o id. In: In: Obras psicológicas completas. Rio de Janeiro: Imago, 1976. v. 19. Edição standard brasileira.

HERBERT, Georges. Le code de la force. Paris: Vuibert, 1911.

INKELES, Alex. Tornando-se moderno: as transformações individuais ocorridas em seis paises em desenvolvimento. Tradução Regina Heloísa Ribeiro Perez e Vera Maria Moyna. Brasília: Editora da UNB, 1981.

KURI, Lorelai; HARGREAVES, Lourdes; VALENÇA, Máslova Teixeira. Ritos do corpo. Rio de janeiro: Senac Nacional, 2000.

LACAN, Jacques. O seminário, livro 3: as psicoses. Rio de Janeiro: Jorge Zahar Editor, 1985.

LÉVY, Pierre. O que é o virtual? Tradução de Paulo Neves. São Paulo: Ed. 34, 1996. 
MARQUES, Luciana Pacheco. O professor de alunos com deficiência mental: concepções e prática pedagógica. Juiz de Fora: Editora da UFJF, 2001.

MARTINS, Oliveira. Elementos de antropologia. Lisboa: Guimarães \& Cia, 1954.

MAUSS, Marcel. Sociologia e antropologia. Tradução Paulo Neves. São Paulo: Cosac \& Naify, 2003.

MONDIN, Battista. O homem: quem ele é? elementos de antropologia filosófica. São Paulo: Paulus, 2003.

SÉRGIO, Manuel. Alguns olhares sobre o corpo. Lisboa: Instituto Piaget, 2003. (Coleção: Epistemologia e sociedade)

. Um corte epistemológico: da educação física à motricidade humana. Lisboa Portugal: Instituto Piaget, 1999. (Coleção: Epistemologia e sociedade)

SILVA, Renato Izidoro da. Psicanálise e educação: vias para subversão do sujeito. InterAção. Revista da Faculdade de Educação, Goiania, v. 32, n.1, jan./jun. 2007.

SOARES, Carmem Lúcia. Georges Hébert e o método natural: nova sensibilidade, nova educação do corpo. Revista Brasileira de Ciências do Esportes, v. 25, n. 1, p. 21-39, set. 2003.

TODOROV, Tzvetan. A conquista da América: a questão do outro. Tradução Beatriz Perrone-Moisés. São Paulo: Martins Fontes, 2003. 



\section{ATENDIMENTO EDUCACIONAL ESPECÍFICO}





\title{
AUTISMO: uma abordagem tamanho família
}

\author{
Mariene Martins Maciel \\ Argemiro de Paula Garcia Filho
}

\section{INTRODUÇÃO}

Os Transtornos Globais do Desenvolvimento (TGD), também chamados de espectro autista, formam um conjunto de síndromes definidas por alterações no comportamento que, normalmente, são observadas em crianças entre os dois e três anos de idade. À exceção da síndrome de Rett, ocorrem quatro vezes mais em meninos do que em meninas e se caracterizam por comprometimentos qualitativos na interação social, na comunicação e na manifestação de interesses restritos e repetitivos. Não há consenso entre a comunidade científica sobre as causas do autismo. Pode apresentar de formas suaves a graus severos de comprometimento, podendo vir associado a outras síndromes, como Down, Williams, $\mathrm{X}$-Frágil, afetando ainda mais a pessoa. Muitos têm inteligência média, podendo mesmo ser bastante inteligentes.

A palavra autismo surgiu nas descrições da esquizofrenia, em 1908, cunhada por Eugene Bleuler, em correspondência com Freud. Em 1943, dois médicos austríacos, Leo Kanner e Hans Asperger, o primeiro morando nos Estados Unidos, o segundo, na Áustria, a usaram para descrever o mesmo padrão de comportamento: crianças e jovens que se mantinham alheios às pessoas à sua volta, demonstravam interesse fixo em assuntos restritos, linguagem mecânica, quando falavam, tendência à rotina e à mesmice. O estudo de Hans Asperger, envolvendo cerca de 200 pacientes e publicado em alemão em 1944, permane- 
ceu esquecido do grande público médico, até que Lorna Wing, médica inglesa mãe de um garoto autista, traduziu-o para o inglês, em 1981.

Apesar do senso comum afirmar que as pessoas autistas não vivem neste mundo, que são a ele totalmente alheios, não é exatamente isso que ocorre: essa falsa impressão se dá pelo fato de perceberem o mundo de forma diferente da maioria das pessoas e apresentarem respostas fora dos padrões pelos quais estas reagem. Seu aparente alheamento mascara o fato de que em geral estão presentes e são extremamente sensíveis, mas têm dificuldades para se comunicar. Essa ideia de que vivem em seu próprio mundo surgiu quando os primeiros pesquisadores compararam o autismo com a esquizofrenia - cujos portadores constroem verdadeiros mundos imaginários.

O diagnóstico do autismo baseia-se na observação do comportamento, e não em exames clínicos. Segundo as normas da Associação Americana de Psiquiatria, "na quarta edição do Diagnostic and Statistical Manual of Mental Disorders (DSM-IV)", para que uma pessoa seja diagnosticada como autista é preciso que a pessoa apresente seis ou mais dos itens a seguir, com pelo menos dois do grupo 1, um do grupo 2 e um do grupo 3. Há quem chame as três áreas afetadas de "tríade autista": socialização, comunicação e comportamentos focalizados e repetitivos.

1) Grupo 1 - Deficiências na interação social:

- dificuldade de se comunicar através de gestos e expressões facial e corporal;

- não faz amizades facilmente;

- não tenta compartilhar suas emoções (Ex.: não mostra coisas de que gostou);

- falta de reciprocidade social ou emocional (não expressa facilmente seus sentimentos, nem percebe os sentimentos alheios).

2) Grupo 2 - Deficiências na comunicação:

- atraso ou falta de linguagem falada;

- nos que falam, dificuldade muito grande em iniciar ou manter uma conversa;

- uso estereotipado e repetitivo da linguagem (usa frases de propagandas, filmes novelas, programas de televisão, trechos ou músicas inteiras);

- falta de jogos de imitação (Ex: representar o papai, a mamãe, a professora algo muito comum nas brincadeiras de crianças). 
3) Grupo 3 - Comportamento focalizado e repetitivo:

- preocupação insistente com um ou mais padrões estereotipados (Ex.: não misturar alimentos no prato, não ingerir alimentos com determinadas texturas, seguir sempre o mesmo ritual para determinadas tarefas);

- assumir de forma inflexível rotinas ou rituais (ter "manias" ou focalizar-se em um único assunto de interesse);

- maneirismos motores estereotipados (agitar ou torcer as mãos, bater a mão uma na outra, ficar olhando fixamente as mãos, ter sempre um objeto de interesse e ficar manipulando este objeto);

- preocupação insistente com partes de objetos, em vez do todo (fixação na roda de um carrinho ou hélice de ventiladores, por exemplo).

Grande parte das pessoas autistas tem Distúrbio de Integração Sensorial (DIS): seus sentidos podem ser hipo ou hiperdesenvolvidos. Podem ser capazes de ouvir sons quase inaudíveis, como um alfinete caindo ao chão ou a água correndo nos encanamentos, ou ter sensibilidade a ruídos altos, como liquidificadores e furadeiras; sentir cheiros imperceptíveis para as demais pessoas; podem não suportar luzes fluorescentes, por perceber a luz oscilando como um estroboscópio devido à corrente alternada; toques e outros contatos lhes podem ser desagradáveis, assim como texturas de tecidos e alimentos. Temple Grandin (1992), engenheira e autista, explica que uma criança autista cobre seus ouvidos porque certos sons lhe doem. Afirma: "o barulho freqüentemente faz meu coração disparar".

O americano Jim Sinclair (1993), também autista, explica que a comunicação é difícil, mas totalmente possível. Para ele, é como ter uma conversa íntima com uma pessoa que não entende sua língua: ela não vai entender o que você está falando; não vai responder da forma que você espera e pode mesmo achar confusa e ruim a interação. Para ele, autistas são estrangeiros em qualquer sociedade.

Embora suas causas ainda não estejam determinadas, as características que determinam se uma pessoa é autista, bem como formas para que atinja um desempenho que lhe garanta, em algum nível, uma vida independente, são bem conhecidos. Há muitas coisas que podem ser feitas pela pessoa autista. A principal é acreditar que tem potencial para aprender. Também é preciso saber que enxerga o mundo de uma forma diferente, mas vive nele. Algumas pessoas autistas conseguem se formar, constituir família e ter uma vida profissional normal. Há quem nunca suspeitou de sua condição, vivendo como uma pessoa deslocada na sociedade. 
É preciso lembrar que, devido à sua dificuldade em se comunicar, podem ter um desempenho fraco na escola. Nos casos mais graves, devido à desinformação dos adultos, pais e profissionais da Saúde e da Educação, a criança autista fica condenada a viver em um mundo que não consegue compreender. Nesses casos, pode crescer frustrada e responder ao mundo com gritos e com agressões, para descarregar sua frustração em não ser compreendida.

O primeiro passo é identificar o mais cedo possível que a criança é autista. O papel do professor da pré-escola é fundamental, tanto quanto o do pediatra. A partir do diagnóstico precoce, é preciso iniciar uma estratégia educacional para superar as dificuldades da criança, de forma que ela consiga se relacionar com as outras pessoas e, assim, possa aprender. Leonardo Ferreira, brasiliense, autista, tem o segundo grau completo, carteira de habilitação, nunca foi multado, e é fascinado por aviões. Ele afirma que o amor dos pais e a sua confiança foram fundamentais para seu pleno desenvolvimento. (NOGUEIRA, 2002).

Não existe uma intervenção única ou tratamento que funcione para todo autista, mas o que é defendido por muitos especialistas, como Rivière (2004), é a participação intensa e estreita colaboração da família, cujo envolvimento é fator relevante no êxito dos trabalhos educacionais e terapêuticas com crianças autistas.

\section{QUANDO A SOLUÇÃO ESTÁ NO PROBLEMA}

Este é um breve relato das estratégias que nossa família adotou para lidar com o autismo de nosso filho mais novo, Gabriel. Como em muitos casos, entre os dois e três anos de idade, ele deixou de se comunicar, parecia "ausente" por longos períodos, não respondia a chamados e se comportava como se estivesse surdo. Uma peregrinação por médicos não trouxe respostas: nós mesmos levantamos a hipótese de autismo, embora não soubéssemos claramente do que se tratava. Um diagnóstico formal só foi dado quando tinha a idade de nove anos e meio, em janeiro de 2003.

Centramos o trabalho na inclusão familiar, baseando-nos em ludicidade e música, muitas vezes contrariando as indicações dos especialistas: uma psicóloga afirmou que, se permanecêssemos cantando para nos comunicarmos, o garoto nunca falaria. Ao contrário, quando percebemos que nosso menino usava a música no lugar da fala, a adotamos como uma forma de comunicação, assumindo que sua vida tinha trilha sonora: para cada situação, uma música-tema. 
Da mesma forma, houve quem nos orientasse a reprimir estereotipias e ecolalias e limitar o tempo de atividades como o pular na cama elástica. Outra vez, contrariamos as recomendações: aceitamos as "manias", muitas vezes redirecionando-as e incorporando-as às brincadeiras, um caminho seguro para fazer dele uma pessoa feliz, integrada, capaz de aceitar com naturalidade beijos, abraços e afagos e retribuí-los com carinho e amor. Acabamos encontrando respaldo na literatura para confirmar que estávamos na direção correta.

\section{JORNADA}

Gabriel nasceu após oito meses de gravidez, em 23 de junho de 1993, na cidade fluminense de Macaé, na quarta operação cesariana da mãe. A obstetra dizia que o útero estava "fino como um papel".

Sua primeira infância não se caracterizou por nada que chamasse a atenção. Era um bebê risonho, interagia bem com os irmãos, prestando atenção ao que faziam. Para se comunicar, usava palavras soltas, chamando as pessoas da família pelo nome.

Em dezembro de 1994, o pai foi transferido para Salvador, numa mudança apressada. Em junho de 1995, Gabriel contraiu uma infecção por rotavírus que fez com que perdesse dois de seus dez quilos em apenas quatro dias. $\mathrm{Na}$ volta para casa, continuou risonho e curioso, embora muito magro, e continuava se comunicando como já fazia. Ao final desse ano, já se percebia que não olhava quando era chamado, passando longos períodos entretido com o nada. Deixou de falar, usando música para expressar seus desejos e necessidades. Por exemplo, cantava uma paródia de Frère Jacques para pedir "meu lanchinho, meu lanchinho, vou comer, vou comer..."

Dos três aos oito anos, passou por quatro escolas regulares; dos oito aos 11, frequentou uma instituição de ensino especial e, com 12, voltou à escola regular - neste caso, montessoriana. Por todas as instituições pelas quais passou, o suporte para sua aprendizagem era dado por nossa família, mesmo na escola especial. Desenvolvemos um método centrado em músicas, uma das coisas que mais lhe dá prazer, visando a sua aprendizagem do conteúdo sistemático. Atualmente, fazemos a adaptação do conteúdo pedagógico para ser trabalhado na classe regular, pesquisando obras que cantem os temas estudados e montando apostilas com breves comentários e muitas figuras ligadas às letras pesquisadas. 
A integração e inclusão da criança na vida da família e na comunidade são fundamentais para seu desenvolvimento. Gabriel nunca foi afastado das atividades diárias. No afã de trazê-lo para o mundo da comunicação, e também para garantir sua autonomia dentro de casa, primeiro passo para sua independência, os afazeres domésticos contavam com sua presença, no colo e, até, literalmente inserido no contexto, como quando a mãe lavava roupa com ele dentro do tanque. Atividades como escolher ou debulhar feijão, fazer massa de bolo ou pastel, bater suco no liquidificador, lavar os banheiros, quaisquer tarefas contaram sempre com a sua participação.

À medida que crescia, passou a se aventurar sozinho, como certa vez, em 2002, quando fritou seis ovos, um depois do outro. Fazer brigadeiro é uma arte que domina desde 2004, quando aprendeu a controlar o ponto, de forma a não queimá-lo. Se, de início, ele se sentava em frente ao forno, gritando até o bolo ficar pronto, hoje sabe bater a massa e pede: "Acende forno!" Então, a põe para assar e espera pacientemente o resultado. Também cozinha macarrão, refogando o molho de extrato de tomate e cebola. (GARCIA FILHO; MACIEL, 2008). ${ }^{1}$

Hoje com 15 anos, evoluiu de uma condição de autista clássico para autista de alto funcionamento ou síndrome de Asperger (24 pontos), segundo o teste I.D.E.A., de Rivière (BEREOHFF, 2005).

\section{APRENDER E BRINCAR É SÓ COMEÇAR!}

A abordagem adotada com Gabriel foi empírica, baseada principalmente na percepção de que nosso filho precisava, para se integrar ao mundo, ser incluído no contexto familiar e, para tanto, o caminho do brincar mostrava-se o mais fácil. Mas há farto referencial teórico para embasar essa estratégia.

Vigostki (apud OLIVEIRA, M., 1992, p. 24) afirma que a construção da personalidade se faz de maneira dialética, o indivíduo só se constitui como ser humano na sua relação com o outro social: para se humanizar, precisa crescer num ambiente social e interagir com outras pessoas. A aquisição da linguagem mostra que o desenvolvimento psicológico humano e todas as funções superiores são originárias das relações reais entre os indivíduos, que vão tomando formas mais complexas à medida que o sujeito vai interagindo com o meio social e as relações mediadoras (CHIANELO, 2008). A vida social é instrumento necessário e indispensável para o desenvolvimento integral do homem.

\footnotetext{
${ }^{1}$ Especificamente os comentários dos dias 19 de janeiro e 21 de abril de 2004.
} 
Para Winnicott (1975, p. 63), o brincar é mais que a simples satisfação de desejos, é um fazer constituído de experiências culturais, universal e próprio da saúde, porque facilita o crescimento, conduz a relacionamentos grupais, podendo ser uma forma de comunicação.

Como lembra Maluf (2000), brincar juntos reforça laços afetivos. É uma maneira de manifestar nosso amor à criança. Todas as crianças gostam de brincar com os professores, pais, irmãos, e avós. A criança sente-se ao mesmo tempo prestigiada e desafiada quando o parceiro da brincadeira é um adulto. Este, por sua vez pode levar a criança a fazer descobertas e a viver experiências que tornam o brincar mais estimulante e mais rico em aprendizado. "O processo de construção saudável de nossa identidade se dá através de uma crescente sociabilização”, explica Oliveira, V. (2006, p. 11), prosseguindo: "os rituais e as brincadeiras $[\ldots .$.$] contribuem para a formação,$ manutenção e preservação dos processos cognitivos, afetivo-emocionais e sócio-culturais."

De sua parte, Klinta (2001, p. 27) sustenta que,

[...] no encontro com crianças com necessidades especiais é necessário usar também uma maneira especial. É importante que a criança seja tratada a partir de suas possibilidades e que experimente o sentimento de ser bem-sucedida, de que é capaz no seu meio-ambiente e, talvez, também junto com outras crianças.

Cunha (2002) corrobora esta ideia, afirmando que, para dar prazer a uma criança autista, é preciso entrar em empatia com ela, captando o que seria adequado a sua forma de se expressar. Fazer o que ela está fazendo é um bom começo para estabelecer comunicação. Imitando-a, cria-se sintonia para outras possibilidades.

Grandin (1992) coloca a música como ferramenta facilitadora para a comunicação com pessoas autistas. Conta que, quando frequentou a escola primária, a sua fala não era completamente normal: gastava mais tempo do que as outras crianças para conseguir colocar as ideias para fora. Cantar, porém, para ela era bem fácil.

\section{BRINCANTO PLAY: UM MÉTODO TAMANHO FAMÍLIA}

Nosso método, que batizamos de Brincanto Play, é baseado na ludicidade, na música e na integração à vida da família através das suas atividades diárias, 
mostrando-se eficiente para o nosso caso e para outras famílias, que têm aplicado seus princípios ao receberem orientação pela internet e em congressos.

Brincar é importante. Com sua ludicidade peculiar, a criança autista brinca e interage, a depender da iniciativa e sensibilidade daqueles que a cercam. No caso de Gabriel, as brincadeiras foram e são as grandes aliadas para fazê-lo feliz e integrado.

Ainda há muitas pessoas que acreditam e insistem em afirmar que uma criança autista não sabe brincar, ou que não brinca "de maneira adequada". Ao contrário, os métodos mais eficazes são justamente aqueles que sabem tirar proveito da ludicidade característica da pessoa autista: Floor time, Real Play, Sonrise e Scerts, como o Brincanto Play, apresentam resultados positivos ao estimular familiares e educadores a buscar o contato com a criança autista, respeitando suas idiossincrasias e tirando delas o máximo proveito.

Focado no desenvolvimento da autoestima e da personalidade de pessoas com TGD, bem como voltado para ajudar os familiares a compreenderem suas idiossincrasias, o Brincanto Play trabalha a construção de relações pessoais e dos aspectos cognitivos através de atividades lúdicas e artísticas.

Mas, embora tenha paralelo com esses métodos internacionalmente consagrados, o que diferencia o Brincanto Play é a utilização dos interesses específicos do educando como eixo central, o aproveitamento de oportunidades do cotidiano, rotineiras, como ferramenta de aprendizagem constante e continuada e o uso da música como instrumental de desenvolvimento da oralidade. Também serve de ferramenta para o ensino de conteúdo na rede regular, trabalhando os conteúdos curriculares dentro do interesse focal do educando de forma natural, lúdica e prazerosa.

Nesta abordagem, a família é importante fonte de conhecimento e cultura, colocando-se em favor da criança. Deve ser tratada como a principal aliada, participando do processo de educação, em continuidade e sintonia com o acompanhamento terapêutico e os profissionais.

\section{Criando e adaptando brincadeiras e jogos}

Enfatizamos que cada família tem seu próprio repertório de jogos e brincadeiras, versões daquelas que fazem parte de sua cultura. Aproveitá-las para a comunicação e desenvolvimento da criança autista facilita a sua inclusão no núcleo familiar, primeiro grupo social do qual ela faz parte. No nosso caso, 
músicas e parlendas de nossas infâncias se misturaram com músicas consagradas da MPB.

\section{Galinha do vizinho}

No tradicional jogo, as crianças brincam de roda enquanto contam: "a galinha do vizinho, bota ovo amarelinho, bota um, bota dois...”. Com crianças autistas, uma interação assim é difícil, mas adaptamos a situação, pegando Gabriel pelas mãos e pés enquanto recitávamos a parlenda, balançando-o. Aproveitávamos, assim, o interesse comum a pessoas autistas pelo balançar.

\section{Durim-durim! Sem piscar! Leão da Metro}

Encarar "sem piscar" o parceiro de jogo é difícil para muitas pessoas autistas, mas o prazer da proximidade com a família era um desafio. Inicialmente, começou com outro jogo, durim-durim, em que a mãe aproximava sua testa da testa dele, recitando: "durim, durim, durim" - terminando com "TIM!" quando se tocavam.

O leão da Metro Goldwin Mayer, por sua vez, inspirou brincadeiras em que a mãe ou o pai o "atacavam" rugindo e "abocanhando" partes de seu corpo.

\section{Fazer bolo}

Pais e irmãos, fazíamos toda uma mímica em que Gabriel era a tigela de um bolo imaginário e massagens simulavam a farinha, os ovos, o leite despejados, cada um com onomatopéia própria. Jogos assim serviam para aproximar a família e dessensibilizá-lo do seu DIS.

\section{Cantigas de roda}

Várias cantigas foram cantadas e adaptadas. O sapo não lava o pé e Se esta rua fosse minha, por exemplo, tiveram personagens trocados, lugares modificados, situações novas foram exploradas. No lugar do sapo, a família, vizinhos, conhecidos e até artistas da televisão deixaram de lavar os pés. A cobra que sobe no pezinho de limão subiu em mamoeiros, laranjeiras e outros pés de fruta. Além da interação, acrescentavam-se conhecimentos e reforçava-se nele a certeza de ser capaz de se comunicar. 


\section{CONCLUSÃO}

Reiteramos nossa fé na capacidade da pessoa autista se desenvolver, comunicar-se e, principalmente, ser feliz, autônoma e, mesmo, independente. A intensa participação da família e dos profissionais envolvidos, acreditando sempre que é possível superar as barreiras de comunicação, é peça-chave na educação dessas crianças. Não concordamos com prognósticos generalizadores que rotulam e condenam crianças a um futuro sombrio. Afirmar que a vida se limita a uma sentença ditada pelos genes é uma visão reducionista. Como dizia Feuerstein (2008), "os cromossomos não têm a última palavra."

\section{REFERÊNCIAS}

BEREOHFF, A. M. P. A psicopedagogia aplicada aos portadores de T.I.D. In: CAMARGOS JUNIOR, W. (Org.). Transtornos invasivos do desenvolvimento: $3^{\circ}$ milênio. Brasília: CORDE, 2005. p. 127-138

CHIANELO, S. A neurobiologia e a teoria de Vigotsky: convergências. Revista da Associação Brasileira de Psicopedagogia. [2008]. Disponível em: < http:// www.abpp.com.br/artigos/12.htm>. Acesso em: maio 2008.

CUNHA, N. H. S. Dístúrbios do comportamento. In: CAMARGOS Jr., W. (Org.). Transtornos invasivos do desenvolvimento: $3^{\circ}$ Milênio. Brasília: CORDE, 2002. p. 122-127.

FEURSTEIN, R. A crença na modificabilidade estrutural cognitiva. Aulas ministradas por Feuerstein entre 1995 e 1999. Disponível em: < http://br.groups.yahoo.com/group /autismo >. Acesso em: maio 2008.

GARCIA FILHO, A. de P.; MACIEL, M. M. Canto de Anjo. Salvador, 2008. Disponível em: <http://www.cantodeanjo.blogger.com.br>. Acesso em: 14 nov. 2009.

GRANDIN, T. Uma visão interior do autismo. Tradução de Jussara Cunha de Mello. Disponível em: < http://br.geocities.com/cronicaautista/vida/visaointerior.htm > . Acesso em: maio 2008.

KLINTA, C. Autoconfiança, comunicação e alegria do movimento através dos movimentos Sherborne - "Relation Play". Tradução de Vera O. Juhlin. São José dos Campos: Univap, 2001. 118 p.

MACIEL, M. M.; GARCIA FILHO, A. de P. Aprender e brincar é só começar: o desenvolvimento de Gabriel através do lúdico. XI ENCONTRO DE AMIGOS PELO AUTISMO, 11. 2004. São Paulo. Anais... São Paulo: AMA, 2004. p. 53-64.

MALUF, A. C. M. O lúdico é o parceiro do professor. Psicopedagogia on line, 2000. Disponível em: <http://www.psicopedagogia.com.br/artigos/artigo.asp?entrID $=270>$. Acesso em: maio 2008. 
NOGUEIRA, D. Entre dois mundos. Os desafios e as vitórias dos autistas na busca por uma ponte que os conecte com a realidade. Jornal do Brasil, Rio de Janeiro, 17 nov. 2002.

Revista Domingo, n. 1385 , p. 20-23.

OLIVEIRA, M. K. de.Vygotsky e o processo de formação de conceitos. In: LA TALLE, Y. de; OLIVEIRA, M. K. de; DANTAS, H. Piaget - Vygotsky - Wallon: teorias psicogenéticas em discussão. São Paulo: Summus, 1992.

OLIVEIRA, V. B. Rituais e brincadeiras. Petrópolis: Vozes, 2006.

RIVIÈRE, A. O autismo e os transtornos globais do desenvolvimento. In: MARCHESI, A. et al. Desenvolvimento psicológico e educação: transtornos de desenvolvimento e necessidades especiais. 2. ed. Porto Alegre: Artmed, 2004. p. 234-253.

SINCLAIR, J. Não chorem por nós. 1993. Disponível em: < http://www.autismobr.com.br/home/N-chorem.htm>. Acesso em: maio 2008.

SIQUEIRA NETO, A. C. O brincar no desenvolvimento infantil. [2004]. Disponível em: < http://www.psicologia.org.br/internacional/pscl59.htm>. Acesso em: maio 2004.

WINNICOTT, D. W. O brincar e a realidade. Rio de Janeiro: Imago, 1975. 



\section{DEFICIÊNCIA MENTAL, APRENDIZAGEM E DESENVOLVIMENTO}

Evanir Abenhaim

\section{INTRODUÇÃO}

A deficiência pode ser compreendida a partir de dois paradigmas: o médico e o social. O paradigma médico apresenta a deficiência como condição da pessoa, resultante de um impedimento, limitação, perda ou anormalidade numa parte do corpo ou numa função. A diferença é vista como um estado negativo de funcionamento, como doença ou defeito. O paradigma médico baseia-se numa comparação entre a pessoa e um modelo humano idealizado: quanto mais próximo do modelo, mais perfeito; quanto mais distante, mais imperfeito. A educação, apoiando-se nesse paradigma, concebe o processo educativo como uma tentativa de aproximação do educando ao modelo idealizado.

O paradigma social reconhece que algumas pessoas têm dificuldade para realizar certas funções, mas considera que o fator limitador é a condição imposta pelo contexto social que cria barreiras físicas, programáticas e atitudinais. A diferença é reconhecida como um desafio a ser superado pela sociedade. Não há um modelo humano. Cada pessoa é reconhecida como Ser único e irrepetível com direito a desenvolver sua potencialidade.

Entre nós o paradigma médico prevalece sobre o social e, por conta disso, as pessoas que não atendem ao padrão recebem muitos rótulos. Há uma tentativa de colocar aquela pessoa numa categoria diferenciada, o que justifica sua exclusão social. Uma evidência disso é a adoção, ainda hoje, por muitos dos nossos educadores, do conceito de deficiência mental da Associação Americana 
de Retardo Mental (AAMR) e da Associação Americana de Psiquiatria publicado no Manual Diagnóstico e Estatístico de Transtornos Mentais (DSM-IV), revisado em 1994. A deficiência mental é definida como o estado de redução notável do funcionamento intelectual significativamente inferior à média, associado a limitações pelo menos em dois aspectos do funcionamento adaptativo. A deficiência mental é vista como uma defasagem entre as respostas esperadas para a idade e a realidade sociocultural. A anormalidade é da pessoa. É a pessoa que não consegue se adaptar ao meio.

A partir desse conceito, dentro do paradigma médico, a deficiência mental é identificada como atraso, muitas vezes irreversível, do desenvolvimento. Esse atraso, por si só, justifica a dificuldade para aprender determinados conteúdos.

\section{REPENSANDO O DESENVOLVIMENTO MENTAL}

Segundo Vygotsky (1994), o estado de desenvolvimento mental de uma pessoa não pode ser definido apenas pelas respostas que a pessoa dá. Essas respostas podem contribuir para inferir o nível de desenvolvimento real, mas não são suficientes para determinar o estado de desenvolvimento mental. Esse estado só pode ser determinado se forem revelados o nível de desenvolvimento real e a zona de desenvolvimento proximal. O desenvolvimento mental retrospectivo e o prospectivo.

Segundo Mantoan (1998), as pessoas com déficit intelectual precisam de: competência intelectual - desenvolvida a partir da preservação do direito de viver desafios para desenvolver suas capacidades; autonomia - desenvolvida quando há o reconhecimento do direito de decidir e escolher de acordo com suas necessidades e motivações; considerar o papel do meio social no processo interativo de produção das incapacidades, garantindo-lhes o direito de se desenvolverem como as demais pessoas em ambientes que não discriminem e que, ao contrário, valorizem as diferenças.

Mantoan (1988) defende que todas as pessoas precisam ser colocadas em situações problemas, situações desafiadoras, para aprenderem a viver o desequilíbrio cognitivo e emocional. Sem os conflitos cognitivos as pessoas não conseguem tomar consciência dos problemas a serem resolvidos nem da sua capacidade para enfrentá-los e superá-los. 
Entre nós, em geral, as pessoas que demonstram habilidades cognitivas aquém do esperado são "poupadas" das situações desafiadoras e, consequentemente, dos conflitos cognitivos. Isso geralmente decorre da crença dos educadores na incapacidade dessas pessoas somada a um sentimento de piedade que os leva a acreditar que dessa forma estão evitando um sofrimento desnecessário. Esquecem que os desafios são indispensáveis à aprendizagem. Lembrando Vygotsky (1994) podemos afirmar que o desafio está entre a zona de desenvolvimento real e a zona potencial, na zona de desenvolvimento proximal.

Vygotsky (1994) conceitua aprendizagem como um processo no qual o indivíduo adquire informações, habilidades, atitudes, valores etc. a partir de seu contato com a realidade, o meio ambiente e as outras pessoas. A aprendizagem não é um processo apenas cognitivo, é também afetivo. A cognição e a afetividade possibilitam a eficiência cognitiva. As relações sociais entram como conteúdo estruturante tão fundamental quanto os demais conteúdos. As pessoas que demonstram habilidades cognitivas aquém do esperado são privadas de muitas relações sociais, resultando no que Feuerstein e Rand (1998) chamaram de síndrome da privação cultural: a pessoa é impedida de beneficiar-se dos elementos da sua cultura.

É através da aprendizagem que a pessoa constrói a autonomia intelectual e social. Segundo Delors (2001), para que a aprendizagem resulte em desenvolvimento precisa decorrer de um processo educativo fundado em três princípios: equidade - direito à igualdade de oportunidade considerando o atendimento às diferenças individuais e a igualdade de valor entre as pessoas; pertinência consideração, pela política educacional, das questões culturais para que todos sejam respeitados e se percebam pertencentes ao grupo, apesar das diferenças; excelência - responsabilidade com a educação de qualidade para todos.

Além de princípios norteadores para direcionar as ações educativas é fundamental o respaldo teórico oferecido pelas teorias de aprendizagem. A Teoria da Modificabilidade Cognitiva Estrutural (TMCE) é uma das teorias que pode contribuir para a aprendizagem e o desenvolvimento das pessoas. Essa teoria começou a ser desenvolvida por Reuven Feuerstein após a $2^{\mathrm{a}}$ guerra mundial, a partir da sua necessidade de interagir com pessoas oriundas de campos de concentração e que apresentavam déficit cognitivo, demência e distúrbios de comportamento. Muitas dessas pessoas tiveram seu cérebro submetido a experiências em laboratórios. 
Feuerstein (1980) percebia que aquelas pessoas não interagiam com o meio e que essa dificuldade de interação não era determinada pela sua condição física ou mental, mas: pela falta de mediação e de instrumentos de mediação adequados; pela crença da própria pessoa e dos outros na incapacidade; pela falta de motivação intrínseca. O resultado disso era a passividade intelectual que funcionava como um impedimento da sua ação no mundo e com o mundo. Ele entendeu que era preciso ajudá-las a moverem-se da passividade intelectual para ascenderem ao nível representativo do pensamento. Ele acreditou que somente assim essas pessoas resgatariam a dignidade.

A TMCE é fundamentada nos seguintes pressupostos filosóficos: toda pessoa tem mais potencial internalizado do que é capaz de demonstrar - é possibilidade; todas as pessoas podem ampliar a propensão para a aprendizagem; todo ser humano é dotado de estrutura cognitiva que possibilita sua interação com o meio para a construção do conhecimento - nem a genética tem a última palavra; o mediador pode contribuir para o mediado aprender a aprender através de uma metodologia que leve em conta critérios e leis da aprendizagem.

Essa teoria enfatiza a capacidade do ser humano de modificar a estrutura do seu funcionamento cognitivo para adaptar-se às diversas situações de vida. Percebendo todo ser humano como um sistema aberto, acessível a mudanças ao longo da vida, com diferenças individuais de desenvolvimento. Afirma que o desenvolvimento humano se dá através da interação do sujeito historicamente situado com o ambiente sociocultural onde vive exigindo a presença de mediador humano e de instrumentos adequados.

Devido à estreita relação entre aprendizagem e inteligência, é importante ressaltar o conceito de inteligência apresentado por esse teórico. Para Feuerstein (1980) a inteligência é um processo amplo que abriga uma enorme variedade de fenômenos. Esses fenômenos têm em comum a dinâmica da adaptação, indispensável para a resolução de problemas. Integra tanto elementos puramente cognitivos como criativos e motivacionais. Feuerstein (1980) afirma que a essência da inteligência não se estabelece no produto mensurável, mas na construção ativa do indivíduo, o qual tem capacidade para usar experiências adquiridas previamente, para ajustar-se a novas situações. Para que ocorra a aprendizagem o processo educativo precisa propiciar experiências que possibilitem a construção ativa do individuo e que tenham significado e transcendência contribuindo para o ajuste a novas situações.

Segundo Feuerstein, Klein e Tannebaum (1991), aprender é construir representações mentais a partir do autoconhecimento e do conhecimento. A 
aprendizagem ocorre através da mediação e da realização de atos mentais. Três fatores são fundamentais nesse processo: capacidade, necessidade e orientação.

A capacidade é indispensável para a interação da pessoa com o conteúdo presente. Potencialmente a capacidade está presente em todas as pessoas, cabe ao mediador verificar a capacidade naquele momento e buscar meios ou instrumentos de mediação que contribuam para seu desenvolvimento.

A necessidade de aprender é um fator energético-motivacional da aprendizagem, que contribui para dar significado ao objeto de conhecimento e levar a pessoa a realizar o esforço necessário para interagir com o meio e aprender.

A orientação diz respeito à ação do mediador e do mediado. Inicialmente o mediador é o responsável por prover os meios para que ocorra a interação do mediado com o meio. A intervenção do mediador deve contribuir para a construção da autonomia do mediado e sua presença deve ser cada vez mais dispensável, até que a pessoa, anteriormente mediada, oriente-se no seu processo de aprendizagem.

O mediador deve contribuir para que o mediado desenvolva a consciência metacognitiva e possa utilizar espontaneamente estratégias cognitivas, desenvolva cada vez mais a consciência de suas habilidades mentais, que autoregule seus processos mentais e autocontrole a impulsividade possibilitando a generalização da aprendizagem.

Vygotsky (1994), contribui para a compreensão do pensamento de Feuerstein quando afirma que no processo de desenvolvimento e de aprendizagem o indivíduo não é mero recipiente a ser preenchido, nem mesmo um ser potencial, inatista, que teria nascido com o conhecimento a ser desenvolvido. Afirma ainda que o desenvolvimento não é a simples relação entre a maturação e o aprendizado. Ele defende que é nas interações que o ser humano estabelece com os outros e com o mundo, uma relação mediacional, que ele vai apropriando-se do real de forma ativa num processo de internalização; isto é, a reconstrução interna de uma operação externa.

Buscando contribuir para que as pessoas com baixo funcionamento cognitivo conseguissem se apropriar do real de forma ativa Feuerstein (1980) desenvolveu o Enriquecimento Instrumental. É um instrumento de intervenção cognitiva, composto de 14 cadernos que objetivam trabalhar as funções cognitivas, desenvolver as operações mentais, ampliar vocabulário e construir conceitos, favorecer a motivação intrínseca, fomentar os processos de pensamento reflexivo para a generalização da aprendizagem. Tudo isso contribuirá 
para que a pessoa se perceba independente, ativa e capaz de interagir com o mundo. O Enriquecimento Instrumental Feuerstein é instrumento de mediação do ato mental. Para efeito didático Feuerstein dividiu o ato mental em três etapas: aproximação da pessoa do objeto de conhecimento, elaboração e resposta.

Feuerstein (1980) compreendeu que para a pessoa se aproximar do objeto de conhecimento e interagir com ele necessita desenvolver percepção clara e precisa, comportamento exploratório sistemático, utilizar vocábulos e conceitos adequados, desenvolver a orientação espaço-temporal, compreender a conservação, constância e permanência do objeto, desenvolver a precisão e exatidão na coleta de informações e aprender a utilizar mais de uma fonte de informação simultaneamente.

A eficiência das funções cognitivas de aproximação possibilita o desenvolvimento das funções cognitivas de elaboração que são: precisão e definição do problema, diferenciação entre dados relevantes e irrelevantes, comportamento comparativo espontâneo, ampliação do campo mental, percepção global da realidade, utilização da evidência lógica, interiorização do próprio comportamento, utilização do raciocínio hipotético-inferencial, desenvolvimento de estratégias para verificação de hipóteses, planejamento do próprio comportamento, conduta somativa, elaboração de categorias cognitivas e estabelecimento de relações virtuais. O desenvolvimento da capacidade para elaborar informações é imprescindível para a construção da autonomia e a consequente ação no mundo.

A capacidade de elaboração mantém estreita relação com a representação mental. Feuerstein (1980) acredita que sem desenvolver a capacidade para elaborar a pessoa dificilmente conseguirá representar mentalmente os objetos de conhecimento e apreendê-los.

A última fase do ato mental é a resposta. Essa resposta pode ser compartilhada ou permanecer com a pessoa como sua conclusão. As funções cognitivas desenvolvidas quando o foco do enriquecimento instrumental é essa etapa, são: comunicação não-egocêntrica, projeção de relações virtuais, comunicação sem bloqueio, eliminação de respostas por ensaio e erro, utilização de vocabulário e conceitos adequados, precisão e exatidão na comunicação da resposta, eficácia no transporte visual e controle da impulsividade.

Para Feuerstein (1980) as questões de aprendizagem têm um cunho fortemente cognitivo, porém não exclusivamente, e precisam ser vistas como tal. 
Ele defende que existem diferenças de funcionamento cognitivo, mas que a deficiência mental só existe quando não há mediação adequada e não são utilizados os instrumentos necessários para que cada pessoa possa aprender a aprender e desenvolver continuamente seu potencial.

O enriquecimento instrumental tem sido reconhecido como instrumento de mediação capaz de atender a essa necessidade humana porque contribui para o desenvolvimento da consciência metacognitiva - facilitando o uso espontâneo de estratégias cognitivas para a solução de problemas - e amplie o nível de consciência de suas habilidades mentais acarretando na autoregulação dos processos mentais.

\section{CONCLUSÃO}

O grau de comprometimento intelectual não é fator determinante da não aprendizagem. A crença no limite do outro é muito mais danosa pois resulta numa autoimagem negativa e em baixa autoestima. As pessoas identificadas como incapazes geralmente assumem essa condição e acreditam que jamais poderão modificar esse resultado.

Quando se trata da pessoa reconhecida como deficiente mental Mantoan (1998) acrescenta a essas, outras questões: geralmente a escola "inclui" essa pessoa em grupo ou classe considerando mais o interesse da escola que as necessidades intelectuais e sociais da pessoa; a idade cronológica é desconsiderada e substituída por uma suposta idade mental, em consequência disso há o impedimento à representação de papéis sociais correspondentes a idade, gênero e cultura acarretando perda da significação social das aprendizagens; o esforço para se adaptar as demandas da escola nem sempre é percebido ou bem sucedido, gerando a consciência de que não conseguirá aprender sem a ajuda constante de alguém "normal" o que determina a dependência e subordinação a condutas, escolhas e resposta daqueles que são "melhores" do que ela.

A aprendizagem e o desenvolvimento das pessoas não podem ser determinados pela aparência. O que realmente limita é a sociedade, principalmente a escola, que não se estrutura para atender as demandas de uma humanidade diversa.

A visão excludente e alienante do ser humano está sendo substituída por um reconhecimento de todo ser humano como ser social que aprende na relação com o mundo, com o outro. A aprendizagem toma outra dimensão na qual são 
consideradas as necessidades individuais e as condições do meio social. Muitos autores, inseridos no paradigma social, têm contribuído para essa mudança de visão.

\section{REFERÊNCIA}

AMERICAN ASSOCIATION ON MENTAL RETARDATION. The definition of metal retardation. Disponível em: <www.aamr.org >. Acesso em: 01 fev. 2007.

DEFICIÊNCIA (Retardo) mental. In: AMERICA PSYCHIATRIC ASSOCIATION. DSMIV Online - Manual de diagnóstico e estatística das perturbações mentais. 4. ed. Washington, DC.: APA, [2000]. Disponível em: <www.psicologia.com.pt/instrumentos/dsm_cid/ dsm.php>. Acesso em: 01 fev. 2007.

DELORS, J. (Org.). Educação: um tesouro a descobrir. 5. ed. Tradução de José Carlos Eufrázio. São Paulo: UNESCO, 2001.

FEUERSTEIN, R. Instrumental enrichment. Illinois: Scott, Foresman and Company, 1980.

FEUERSTEIN, R.; KLEIN, P.; TANNEUBAUM, A. Mediated learning experience. Jerusalem: ICELP, 1991.

FEUERSTEIN, R.; RAND, Y. Don't accept me as I am. Chicago: Skylight, 1998.

MANTOAN, M. T. E. Compreendendo a deficiência mental: novos caminhos educacionais. São Paulo: Scipione, 1988.

. Educação escolar de deficientes mentais: problemas para a pesquisa e o desenvolvimento. Campinas, Cadernos Cedes, v. 19, n. 46, set. 1998.

VYGOTSKY, L. S. A formação social da mente: o desenvolvimento dos processos psicológicos superiores. 5. ed. São Paulo: Martins Fontes, 1994. 


\section{O FAZER PEDAGÓGICO DIANTE DO TRANSTORNO DE DÉFICIT DE ATENÇÃO E HIPERATIVIDADE NO CONTEXTO ESCOLAR}

Diana Maria Pereira Cardoso

Para a maioria dos professores, a falta de atenção, o excesso de agitação, a dificuldade para seguir instruções, controlar as emoções e as atitudes impulsivas dos alunos representa um caos no contexto escolar e tormento ao lidar com a situação.

É comum no ambiente escolar encontrarmos graus variados de atenção, agitação e impulsividade, no entanto, há alunos que são incapazes de controlar esses comportamentos em decorrência de um transtorno neurobiológico de caráter hereditário conhecido como Transtorno de Déficit de Atenção e Hiperatividade (TDAH).

Reconhecer a hiperatividade, a desatenção e a impulsividade como sintomas de um transtorno, não deixa de ser complexo, pois a realidade nos mostra o quanto a escola está despreparada para atender a diversidade. Há alunos que manifestam alterações no comportamento provenientes não de uma patologia, mas sim, de uma práxis social e pedagógica que reforça ou desencadeia esses comportamentos. Diante disso, cabe ao professor investigar em que situações do ambiente escolar o excesso de agitação, impulsividade e dificuldade em fixar a atenção tornam-se mais evidentes.

É preciso que o professor obtenha conhecimentos básicos através dos profissionais de saúde mental acerca do TDAH para que possa desenvolver as com- 
petências que lhe cabem, enquanto professor, e também em casos específicos, observar comportamentos destoantes, não com um olhar patologizante, mas reflexivo e crítico, levando em consideração o contexto socioeducacional em que o aluno está inserido e revendo também, a práxis pedagógica adotada pela escola. Somente tendo uma postura crítica e investigativa é que o professor poderá contribuir com observações e registros sobre o comportamento manifestado pelo aluno no contexto escolar.

Embora haja inúmeros estudos científicos sobre o TDAH, ainda não são conclusivas as investigações sobre a etiologia do transtorno. Apesar de as evidências de alterações genéticas neuroanatômicas e neurofuncionais estarem presentes nas pessoas que apresentam esse transtorno, não podemos ignorar que a educação tem muito a contribuir no diagnóstico clínico multidisciplinar do TDAH. É imprescindível, portanto, que o professor tenha conhecimento acerca do transtorno e dos aspectos psicológicos, sociais e educacionais que envolvem a presença de comportamentos inadequados em ambiente escolar.

Somente quando o professor estiver imbuído de informação científica, antenado aos comportamentos que se assemelham ao TDAH e com um olhar crítico sobre a realidade educacional poderá fazer as seguintes indagações: até que ponto os sintomas ocorrem em decorrência de um mau funcionamento neurobiológico, isto é, de uma anormalidade do desenvolvimento do cérebro proveniente de fatores hereditários? Ou será que eles surgem por conta de um jeito de ser particular do sujeito que não se satisfaz com a motivação e estimulação oferecida pelo ambiente escolar? Ou quem sabe, estará o comportamento inadequado do aluno representando como resposta a modalidade de uma práxis pedagógica incompatível com a necessidade e expectativas deste aluno?

Não é nada fácil responder a questões tão complexas como essas, pois não podemos ignorar que encontraremos no ambiente escolar casos específicos que exigem também tratamento específico, no entanto, até mesmo nesses casos especiais, não podemos desconsiderar a influência do ambiente no comportamento do aluno. Estudos abordam que o ambiente não é o causador do transtorno, mas poderá agravar os sintomas dos comportamentos hiperativos, impulsivos e desatento. Assim sendo, dizer que o ambiente agrava esses sintomas é bastante distinto de dizer que provoca.

Falar da necessidade do professor conhecer o TDAH exigirá desse profissional bastante estudo e reflexões sobre o processo ensino e aprendizagem. Conhecer e distinguir o TDAH da indisciplina escolar é imprescindível para que rótulos e estigmas não surjam no ambiente escolar e o professor não adote intervenções 
indevidas, sem que antes analise o contexto em que o aluno está inserido e faça um levantamento de hipóteses que possam estar desencadeando o comportamento inadequado do aluno. Tanto os rótulos, como as intervenções inapropriadas, além de serem reforçadores potenciais dos sintomas do TDAH, comprometem a interação social e contribuem com a baixa autoestima do aluno.

Como as consequências do TDAH são, em alguns casos, inevitáveis, em geral todos ficam perdidos e se sentem impotentes diante da situação. A começar pelo professor que fica desnorteado e ansioso por não saber qual a melhor maneira para lidar com ela, que, por sua vez, acaba recriminando ou desqualificando o aluno que manifestou desatenção, agitação excessiva e descontrole das emoções, desencadeando a manifestação dos atos impulsivos. Esta realidade educacional reforça cada vez mais a necessidade do professor conhecer sobre o assunto em questão e confrontar com a indisciplina escolar.

A compreensão do professor acerca do transtorno e das questões educacionais implicados trará benefícios para o diagnóstico multidisciplinar e para o aluno. Novos paradigmas surgirão ao tecer parceria entre a saúde e a educação.

Conforme a realidade cotidiana vem se apresentando, caberá ao profissional de educação ampliar seus conhecimentos sobre o comportamento dos alunos em contexto escolar para que adquira capacidade de sinalizar os sintomas característicos da desatenção, hiperatividade e impulsividade, expressos em sala de aula.

Há autores como Goldstein S. e Goldstein M. (2003, p. 79), que ressaltam o seguinte:

os professores da pré-escola podem e devem ser treinados a identificar crianças pré-escolares sob risco não apenas de problemas de hiperatividade, mas também de sinais precoces de incapacidades de aprendizado e outros distúrbios psicológicos, como aqueles relacionados com a ansiedade e a depressão.

É inquestionável a relevância que o professor tem na história do desenvolvimento cognitivo e psíquico da criança, a este profissional caberá observar diariamente, durante o período de aula, o que não é possível o aluno controlar em relação aos sintomas que caracterizam o TDAH.

A informação que o professor poderá obter sobre a criança no ambiente escolar será de extremo valor para o diagnóstico e para identificar as habilidades que devem ser ensinadas por ele, pois terá a chance de observar a criança no momento da realização das atividades individuais e grupais, na maneira como 
interage com os colegas, além de possibilitá-lo fazer comparações com o desempenho das outras crianças da mesma idade. A observação a ser feita deverá se restringir ao comportamento da criança e não deixar que o grau de irritabilidade causado pelo comportamento inadequado do aluno interfira, comprometendo na qualidade e na veracidade dos fatos registrados e observados pelo professor.

O professor deve estar atento para estas questões e manter o equilíbrio e a clareza para não chamar de hiperativas as crianças que demonstram comportamentos ativos apropriados para a idade, sem a priori analisar o contexto social, familiar e educacional, principalmente as condições físicas da criança e do ambiente, bem como a sua própria atuação, enquanto educador. De acordo com o que foi dito " $[\ldots .$.$] as atitudes pessoais dos docentes (relativamente às transgres-$ sões da disciplina escolar e as diferenças entre os próprios professores quanto à tolerância para com as condutas interativas) influem no surgimento de problemas comportamentais nas crianças em idade escolar" (GARCIA, 2001, p. 37). Atingir esse nível de percepção demandará deste profissional, competência, equilíbrio, criatividade, intuição e o jogo de cintura para enfrentar as situações desagradáveis que poderão emergir no cotidiano da sala de aula.

Jones (2004) chama a atenção que a hiperatividade poderá estar na mente do observador, quando diz que dependerá do que se espera do comportamento de uma criança e do grau de tolerância do adulto, pois há crianças consideradas hiperativas, quando seus pais ou outras pessoas criam expectativas diferentes daquilo que elas realmente possam dar.

É incontestável a importância do professor no diagnóstico do TDAH, entretanto, não caberá ao professor diagnosticar e sim compartilhar com outros profissionais as observações, as intervenções adotadas em sala de aula e as preocupações a respeito dos alunos (RIEF; HEIMBURGE, 2000). Os registros das observações feitas pelo professor, a respeito das alterações do comportamento dos alunos, permitirão identificar preventivamente os casos específicos que necessitarão de intervenções educacionais, comportamentais e ambientais adotadas em sala de aula, como também, ajudar na seleção daqueles que precisam de uma atenção particular. A partir daí providências serão tomadas, como por exemplo: contato frequente com os pais, encaminhamento para profissionais da área médica e terapeutas, além do auxílio de outros profissionais.

Não podemos falar nas intervenções ou estratégias educacionais, sem antes abordar as características necessárias ao professor que educará o aluno que manifesta a desatenção, a hiperatividade e a impulsividade em sala de aula. Para Mattos (2003), o professor que se propõe a trabalhar com o aluno que apresenta 
o TDAH deverá ser capaz de adaptar as estratégias de ensino ao estilo de aprendizagem e às necessidades da criança, buscando sempre atividades que motivem e despertem os seus interesses.

Embora hoje exista uma vasta literatura que aborda algumas estratégias para serem executadas em contexto escolar, o professor não poderá aplicá-las sem antes analisar a sua realidade e o contexto na qual a situação desagradável torna-se presente. Não há técnica ou abordagem pedagógica milagrosa que faça desaparecer o TDAH, mas sim, melhorar o nível de atenção, o controle dos impulsos emocionais e comportamentais dos alunos, refletindo de forma positiva nas suas produções escolares e nas interações sociais.

Mattos (2003), Goldstein, S.; Goldstein, M. (2003) e outros autores, revelam que, em geral, as crianças com TDAH apresentam maior dificuldade em concluir tarefas monótonas, repetitivas e que exigem um tempo prolongado para a sua realização, situações que vão além da capacidade de tolerância dessas crianças. O desafio do professor está em aumentar as chances do aluno com TDAH de ser bem sucedido na área acadêmica e social, minimizando as consequências do transtorno no ambiente escolar.

Para diminuir os impactos do TDAH é importante que o professor reveja o estilo que adota para administrar as situações de conflitos, do processo ensino e aprendizagem e de interação social com os alunos em sala de aula. Benczik (2000), reforça a diferença existente entre os estilos pessoais dos professores e fala da importância do professor se conscientizar do seu próprio estilo para que possa buscar as intervenções que mais se adequem a sua realidade.

Levando em consideração os diversificados estilos de professores, Benczik (2000), destaca os seguintes estilos de atuação:

- O professor autoritário: como o nome já diz, é o tipo de professor intolerante e rígido, só se preocupa com as necessidades acadêmicas do aluno, focalizando apenas os resultados das produções das tarefas escolares. Torna-se impaciente com a criança à medida que esta não consegue corresponder às suas expectativas. Este professor terá bastante dificuldade para interagir com o aluno com TDAH, pois o seu estilo reforçará ainda mais os sintomas, principalmente quando se tratar de um aluno hiperativo o rigor excessivo irá apenas contribuir para acentuar as dificuldades e reforçar a baixa autoestima.

- O professor pessimista, desanimado e infeliz: é o tipo de professor que tem tendência em fixar o olhar para o mau comportamento, manifesta extremo negativismo, vê as tarefas inacabadas como proposital e por consideração a ele. Sem dúvida, este tipo de estilo não conseguirá manter um bom relaciona- 
mento com o aluno com TDAH, já que uma das características mais evidentes é o não cumprimento e o esquecimento das tarefas escolares.

- O professor hipercrítico, ameaçador, que "nunca erra": este é o estilo do professor onipotente que se sente perfeito e superior a todos. Certamente ficará frustrado ao se deparar com o aluno com TDAH pela dificuldade que apresenta em fazer mudanças adequadas rapidamente.

- O professor impulsivo, temperamental e desorganizado: não há dúvida que este tipo de professor também sentirá dificuldade em lidar com o aluno com TDAH, pois o seu estilo é bastante similar às dificuldades enfrentadas pelo aluno que têm o TDAH.

Contudo, o estilo de professor que mais se aproxima às necessidades do aluno com TDAH, segundo Benczik (2000), é aquele que revela ser:

· democrático, solícito e compreensivo;

- otimista, amigo e empático;

- capaz de dar respostas consistentes e rápidas para o comportamento inadequado da criança, não manifestando raiva ou insultando o aluno;

- bem organizado;

- flexível e que tenha capacidade para manejar os vários tipos de tarefas, revelando criatividade;

- objetivo e capaz de descobrir meios de auxiliar o aluno a atingir a sua meta.

Além de o estilo ter grande relevância para a sala de aula, é preciso que o professor possa descobrir a modalidade de aprendizagem do aluno e que saiba planejar e organizar o ambiente escolar, reduzindo a presença de estilos visuais e auditivos para que consiga facilitar o processo de aprendizagem do aluno.

Para o professor poder proporcionar a resposta adequada às necessidades da criança é fundamental que este tenha conhecimento sobre o TDAH e as dificuldades enfrentadas pelas crianças que apresentam este problema. Ter conhecimento sobre o transtorno evita a criação de barreiras em relação ao aluno, além de o professor poder oferecer uma atenção e dedicação mais equilibrada aos demais em sala de aula. Fundamentado, é provável que o professor possa amenizar o impacto do transtorno em sala de aula e promover a aprendizagem das habilidades que estão deficitárias. 
As intervenções servirão como ancoragem temporária dos sintomas que acabam prejudicando o desenvolvimento do aluno, porém o professor deverá ter consciência de que não há uma receita pronta para solucionar os problemas que emergem em sala de aula, dependerá muito do desejo, da disponibilidade, da criatividade, da flexibilidade, da intuição e, sobretudo, do seu grau de tolerância diante do comportamento inadequado do aluno.

Faz-se necessário, no entanto, que o professor organize via registros ou portfólio o desempenho do aluno e como o mesmo procedeu em relação às intervenções feitas em sala, procurando sempre trabalhar com os outros membros da equipe multidisciplinar, necessários ao tratamento do TDAH. É no ambiente escolar que se obtém o histórico da vida escolar da criança, seus dados sobre os desempenhos acadêmicos, sociais e emocionais de anos anteriores e é a escola um ambiente privilegiado, onde o professor educa diversas crianças na mesma fase de desenvolvimento, podendo perceber quando a conduta da criança é exagerada e foge do esperado para faixa etária (PARKER, 2005). É neste sentido que Lopes (2004, p. 32) enfatiza que havendo qualquer contradição entre os dados obtidos com os pais e outros adultos que lidam com a criança deve-se a "princípio tornar-se mais fiáveis os relatórios dos professores, devido ao grau superior de conhecimento dos comportamentos de crianças de diferentes idades."

Desta maneira, deduzimos que o papel do professor não é diagnosticar, mas reconhecer os sinais do TDAH em sala de aula, investigar dentro das suas competências outras situações ou condições que podem estar desencadeando os sintomas. Deverá observar as atitudes do aluno diante das regras estabelecidas e das atividades propostas, o modo como ele aprende e se relaciona com os colegas, a maneira que se comporta diante das situações de aprendizagem. Conhecendo melhor seu aluno o professor poderá partilhar informações e solicitar a outros profissionais estratégias de intervenções educacionais e formas de apoio que possam atender as necessidades do aluno. Para que essa parceria obtenha resultados é preciso registrar as intervenções feitas e os pontos positivos e negativos das respostas reativas às intervenções aplicadas em sala de aula e no caso de suspeita do transtorno, orientar os familiares a buscar uma avaliação apropriada com profissionais, especialistas no assunto.

Promover uma práxis pedagógica que atenda as necessidades desse aluno é prioridade, para isso, o professor deverá motivar e encontrar estratégias de ensino para desenvolver as habilidades que estão deficitárias no aluno com TDAH. 
Vale ressaltar que esse aluno demanda que o professor tenha além da competência docente, equilíbrio, criatividade, intuição, e jogo de cintura para enfrentar as situações desagradáveis que poderão emergir no dia-a-dia da sala de aula.

Embora hoje a vasta literatura traga dicas diversificadas para serem executadas em contexto escolar, o professor não poderá aplicá-las, sem antes analisar a realidade dos alunos e o contexto na qual a situação desagradável se faz presente. Não há técnicas ou abordagens pedagógicas milagrosas que façam desaparecer o TDAH, porém, servem para melhorar o nível de atenção do aluno para que possa obter progresso nas produções escolares e nas interações sociais, servindo não como um remédio onde os sintomas serão curados, mas sim como óculos que ajudará ao aluno a enxergar o melhor jeito de pensar e atuar em situações do contexto de sala de aula. Portanto, as estratégias educacionais servirão de ancoragem para os comportamentos que caracterizam o TDAH, podendo estar melhor administrados.

Em geral, as crianças com TDAH apresentam, mais do que as outras, dificuldade em lidar com tarefas monótonas, repetitivas e que exigem um tempo prolongado para a sua realização e como, infelizmente, esta é a realidade enfrentada pelos alunos em algumas escolas, o tumulto toma conta da classe.

Diante das questões levantadas, selecionamos a partir de Antunes (2001), Benczik (2000), Mattos (2003), Rief e Heimburge (2000), e outros que abordam o TDAH, algumas sugestões de intervenções para o professor melhor manejar os comportamentos desatento, hiperativo e impulsivo dos alunos que frequentam as classes de educação infantil e ensino fundamental, como:

- Minimizar as distrações visuais e auditivas do ambiente;

- Organizar a sala e o currículo de maneira que possa conciliar os diferentes estilos de aprendizagem;

- Utilizar diariamente um calendário de registros de tarefas;

- Entregar as tarefas já perfuradas para serem arquivadas no classificador;

- Etiquetar os cadernos, separando as disciplinas;

- Utilizar, com as crianças menores, livros e cadernos com códigos de cores;

- Listar as coisas a serem feitas e colar na carteira com fita adesiva;

- Dividir trabalhos mais extensos em pequenas partes;

- Limitar a quantidade dos materiais expostos na carteira do aluno;

- Promover um contato frequente com os pais para partilhar preocupações e oferecer observações positivas dos alunos; envolvendo a equipe multidisciplinar; 
- Dialogar com o aluno acerca das suas necessidades e dificuldades;

- Aumentar reforços positivos por meio de elogios;

- Estabelecer contrato e regras sociais com a turma;

- Estabelecer códigos de comunicação personalizados;

- Permitir que o aluno participe na escolha de recompensas e consequências;

- Reforçar o apoio dos monitores e os períodos de reforço pedagógico;

- Permitir que o aluno saia da sala por alguns instantes ou fique de pé para que possa voltar a manter a atenção;

- Utilizar dinâmicas que ensinem a partilhar;

- Utilizar música clássica durante as atividades (ex: Mozart);

- Promover situações que possam controlar a ansiedade, administrar frustrações e expectativas;

- Ajudar a se estruturar criando listas, organizando sua agenda escolar, elaborando planos diários, estabelecendo regras para serem seguidas, organizando lembretes dentro de uma hierarquia previsível;

- Escrever ou desenhar no quadro o que foi dito durante a explicação de um assunto;

- Promover atividades de complexidade crescente;

- Encorajar os alunos a expressar sentimentos;

- Promover a troca de mensagens positivas entre os alunos;

- Oferecer apoio externo para ajudar a focar e manter a atenção (ex: marcadores, despertadores etc.);

- Desenvolver atividades que promovam o respeito pela diversidade;

- Criar situações que possam analisar comentários negativos e a forma como as palavras nos fazem sentir;

- Ajudar ao aluno a reconhecer os seus pontos fortes e as suas aptidões, a partir de múltipla atividade e oportunidade;

- Criar um livro em que possa registrar os pontos fortes, tendo cada aluno direito a uma página;

- Promover a tutoria levando o aluno a ensinar ao outro aquilo que sabe fazer bem.

As dicas de intervenções não se esgotam aqui, elas servirão apenas como ancoragem temporária para conter os comportamentos que acabam prejudicando o desenvolvimento social e acadêmico do aluno. Nesse sentido, é preciso 
que o professor tenha consciência de que não há uma receita pronta, mas está em suas mãos a chance de poder modificar a situação escolar de modo que o aluno possa ter êxito.

Enfim, para que se obtenha melhor resultado é importante que o professor organize através de registros ou portfólio o desenvolvimento acadêmico, social e afetivo do aluno e relate como foi seu procedimento diante das intervenções feitas em sala de aula. Sendo o professor uma das fontes de informações consultadas para coleta de dados dos sintomas do TDAH e o profissional mais solicitado pelo aluno, poderá ser de extrema ajuda para auxiliar os profissionais envolvidos na avaliação diagnóstica do transtorno e no processo de aprendizagem e socialização do aluno no contexto escolar.

\section{REFERÊNCIAS}

ANTUNES, C. Miopia da atenção: problemas de atenção e hiperatividade em sala de aula. São Paulo: Salesiana, 2001.

BENCZIK, E. B. P. Transtorno de déficit de atenção/hiperatividade: atualização diagnóstica e terapêutica. São Paulo: Casa do psicólogo, 2000.

GARCÍA, I. Hiperatividade: prevenção, avaliação e tratamento na infância. Tradução de Jorge Ávila de Lima. Portugal: McGraw-Hill, 2001.

GOLDSTEIN, S; GOLDSTEIN, M. Hiperatividade: como desenvolver a capacidade de atenção da criança. 9. ed. Campinas: Papirus, 2003.

JONES, Maggie. Hiperatividade: como ajudar seu filho. Tradução de Denise Maria Bolanho. São Paulo: Plexus, 2004.

LOPES, J. A. A Hiperactividade. Coimbra: Quarteto, 2004.

MASCARENHAS, F. Diagnóstico errado prejudica criança desatenta ou hiperativa. A Tarde, Salvador, 11 ago. 2005. Observatório, p. 12.

MATTOS, P. No mundo da lua: perguntas e respostas sobre transtorno do déficit de atenção com hiperatividade em crianças, adolescentes e adultos. São Paulo: Lemos Editorial, 2003.

PARKER, H. C. Desordem por déficit de atenção e hiperatividade: um guia para pais, educadores e professores. Portugal: Porto, 2005.

RIEF, S. F.; HEIMBURGE, J. A. Como ensinar todos os alunos na sala de aula inclusiva: estratégias prontas a usar, lições e atividades concebidas para ensinar alunos com necessidades de aprendizagem diversas. Tradução de Isabel Maria Pardal Hanemann Soares. Portugal: Porto, 2000. 


\section{DEFICIÊNCIA VISUAL E SURDOCEGUEIRA}

Miralva Jesus dos Santos

Nelma de Cássia Silva Sandes Galvão

Sheila Correia de Araújo

\section{INTRODUÇÃO}

A escola é um espaço onde coexistem diversos atores, que se situam não apenas no espaço da escola, mas também fora dela, em contextos que envolvem a comunidade escolar, a família e outros grupos sociais. Como aprendizes, professores, alunos, funcionários da escola, familiares, estarão convivendo e construindo de forma conjunta o cotidiano da escola, cada um e todos ao mesmo tempo imprimindo a sua marca pessoal e coletiva.

Por isso a escola é entendida como um espaço fundamental para o desenvolvimento e aprendizagem do ser humano, mas ao mesmo tempo as vivências escolares estão de tal forma naturalmente presente nas nossas histórias de vida que só nos damos conta desta importância quando somos impedidos de vivenciar tal realidade. Sacristan (2001) compara a escola ao ato de respirar, só percebemos a sua importância quando privados dele.

É na interação com a comunidade escolar que o aluno dialeticamente constrói a si próprio. Na troca com outro, na alteridade, o sujeito se constitui. É na promoção desse encontro que a escola também tem o seu papel renovado.

Esse texto se inscreve nessa interconexão aluno/escola/aluno, tendo como objetivo socializar informações que possam favorecer e garantir a prática educacional inclusiva, desmistificando tabus e estimulando a interação social real. 
Para isso as reflexões foram organizadas em dois momentos, inicialmente será contextualizada a deficiência visual e a surdocegueira, discutindo o conceito, características e causas das duas deficiências, e no segundo momento serão apresentadas propostas de suporte à inclusão escolar desses alunos.

\section{CARACTERIZANDO A DEFICIÊNCIA VISUAL E A SURDOCEGUEIRA}

O conceito acerca do que é deficiência visual modificou-se ao longo da história. De acordo com Martín e Ramirez (2003), em 1980, a Organização Mundial de Saúde (OMS) sugeriu uma classificação das deficiências visuais ${ }^{1}$ baseada apenas na medida da acuidade visual e do campo periférico. Dessa forma, tinha-se o conceito de cegueira legal difundida em todos os países ocidentais, como: "[...] um olho é cego quando sua acuidade visual com correção é 1/10 $(0,1)$, ou cujo campo visual se encontra reduzido a 20"” (CRESPO, 1980 apud MARTÍN; RAMÍREZ, 2003, p. 40). Ainda na década de 1980, a OMS recomendou que fosse eliminada a categorização, pois estava existindo injustiça nos diagnósticos, embora não tenha sugerido solução alternativa.

No ano de 1992, em Bangkok - Tailândia, houve um congresso histórico onde se encontraram, para discutir a educação das pessoas com deficiência visual, a Organização Mundial de Saúde (OMS) e o Conselho Internacional para Educação de Pessoas com Deficiência Visual (ICEVI). No encontro, foi rediscutida a importância da avaliação clínica, juntamente com uma avaliação funcional da visão, pois se entendia que o desempenho visual é mais um processo funcional dinâmico do que uma simples medida de acuidade visual que ocorre com a pessoa em posição estática (normalmente sentada na cadeira do oftalmologista); já na avaliação funcional, deveria ser observado o que a pessoa faz com o uso da visão que possui, ou seja, ela deve ser avaliada através de atividades funcionais: andando, subindo escada, alimentando-se, brincando, escrevendo etc. (BRUNO, 1997).

Assim, as novas recomendações da OMS e do ICEVI definiram que é considerada cega a pessoa com ausência total da visão, até a perda da projeção de luz, sendo sugerido que o seu processo de aprendizagem se dê através da integração dos sentidos tátil, cinestésico, olfativo, auditivo, gustativo, utilizando o sistema Braile para leitura e escrita. As pessoas com baixa visão são aquelas

\footnotetext{
${ }^{1}$ Deficiência Visual compreende tanto a cegueira quanto a baixa visão.
} 
que apresentam desde condições de indicar projeção de luz até o grau em que a redução da acuidade visual interfere ou limita seu desempenho. Essas pessoas deverão utilizar recursos ópticos e não ópticos para o seu processo de aprendizagem (BRUNO, 1997).

O diagnóstico precoce de deficiência visual, juntamente com a indicação para a intervenção precoce, ${ }^{2}$ ajuda a compreender que a criança com deficiência visual é antes de tudo criança. Que gosta de fazer tudo o que uma criança com visão gosta: ir ao parque, à praia, brincar, assistir televisão, dançar, comer pipoca e brigadeiro. As suas peculiaridades são na forma de perceber e assimilar o seu entorno, e cada uma delas terá uma singularidade, que vai desde possuir a mínima percepção de luz, que a ajudará na orientação e mobilidade, até viver ou transitar em um ambiente com muito preconceito, não aceitando a deficiência.

Pode-se ter também crianças que não vêem nada, e o sentimento de aceitação e pertença ser muito bom, podendo até mesmo compensar a falta de percepção luminosa. Como afirma o fragmento de texto abaixo:

A criança com deficiência visual, como as demais crianças, devem ser vistas conforme suas especificidades. Cada criança é um ser singular, único, com tempo e ritmos diferentes, os quais devem ser respeitados e valorizados em sua espontaneidade, em sua forma diferente de ser, de fazer, de compreender e agir no mundo. (BRASIL, 2002, p. 23).

A maioria das crianças nasce com deficiência visual em decorrência de fatores pré-natal ${ }^{3}$ peri-natal $^{4}$ e pós-natal ${ }^{5}$; contudo, também há crianças que possuem alguma doença hereditária como, por exemplo, glaucoma congênito. ${ }^{6}$

\footnotetext{
${ }^{2}$ Intervenção Precoce é o acompanhamento que visa capacitar a criança, por meio do apoio aos pais e/ ou cuidadores a ter um desenvolvimento que lhe possibilite alcançar habilidades que a torne bem sucedida e incluída na sociedade (DESSEN; SILVA, 2005).

${ }^{3}$ Pré-natais é quando o problema é antes do nascimento.

${ }^{4}$ Perinatais é quando o problema da criança ocorre no momento do nascimento. Os casos mais frequentes no nosso país são de anoxia perinatal (falta de oxigênio ao nascimento), que podem deixar várias sequelas e entre elas a deficiência visual.

${ }^{5}$ Pós-natal é quando a patologia ocorre no cérebro imaturo, que para a maioria dos autores seria até os dois anos de idade. O mais comum é a meningite bacteriana ou acidentes por queda ou afogamento.

${ }^{6}$ Glaucoma é o aumento da pressão interna dos olhos. Quando a criança nasce com esse diagnóstico, frequentemente cursa para cegueira.
} 
O Ministério da Educação afirma que as crianças com deficiência visual, em função da sua privação sensorial ocasionada pela ausência ou baixa visão, deverão ter mais tempo para elaborar a noção de objeto permanente; para se desligar da figura materna; para se adaptar à escola; além do que alguns movimentos corporais de repetição não deverão ser entendidos como deficiência mental, mas como forma de manifestar tensão, agitação e diversos sentimentos como alegria e ou tristeza (BRASIL, 2002).

Assim, o entendimento sobre a deficiência visual e outras deficiências sensoriais, como a surdocegueira por exemplo, nos aponta que importante se faz entender a pessoa em seu próprio contexto de vida e identificar as suas singularidades e habilidades para a aprendizagem.

A literatura especializada na atualidade denomina como surdocega a pessoa que tem concomitantemente visão e audição atingidas por alguma disfunção. Apesar da presença de comprometimento em duas vias sensoriais, a surdocegueira não é entendida como uma deficiência múltipla. Pelo contrário, é considerada como um tipo de deficiência específica que não é apenas o somatório das duas deficiências, visual e auditiva, mas uma condição singular que demanda um atendimento diferenciado do prestado a criança só cega ou só surda (MASINI, 2002; CEDER-NASCIMENTO, 2005).

Dentre as causas mais frequentes da surdocegueira pode-se elencar: causas pré-natais como enfermidades produzidas por vírus (ex: rubéola, sarampo); desordens genéticas a exemplo da síndrome de Usher, uso e abuso de álcool e/ ou outras substâncias psicoativas na gravidez; causas perinatais como prematuridade com complicações, hiperbilirrubinemia; causas pós-natais como meningite, traumatismos.

Considerando as possibilidades de intersecção entre os tipos de deficiência visual e os tipos de deficiência auditiva, existirão então diferentes tipos de surdocego, desde aqueles que têm perda total visual e auditiva, até aqueles que têm um bom resíduo visual e/ou um bom resíduo auditivo.

Um outro aspecto relevante a ser considerado na conceituação da surdocegueira diz respeito ao período em que ocorreram as perdas, se antes ou depois da aquisição da linguagem falada. Quando a criança adquire a deficiência antes de aprender a falar, ela está dentro do que à literatura especializada denomina com surdocegueira pré-linguística. Caso as duas perdas ocorram após a aquisição da linguagem falada, considera-se que a pessoa é um surdocego póslinguístico. 
Noguer e Rey (2004) informa que a surdocegueira pode ser entendida também na dimensão nível de funcionamento, que corresponderia a três situações possíveis: baixo, médio e alto nível de funcionamento. Maia (2004) ao discorrer sobre esses três níveis aponta para as possibilidades cognitivas das pessoas surdocegas, destacando que mesmo no nível mais baixo de funcionamento onde "o comprometimento severo dos sentidos de distância interfere no impulso ou desejo para interagir e aprender sobre o ambiente" (MAIA, 2004, p. 9), a intervenção adequada pode garantir que a pessoa com surdocegueira possa conquistar autonomia para atividades básicas. A autora aponta ainda que no nível de alto funcionamento os avanços acadêmicos são resultados possíveis, afirmando que as pessoas com surdocegueira "são capazes de levar uma vida e aprendizagem normal com as ajudas necessárias” ( MAIA, 2004, p. 9).

Existem diversas formas de comunicação que a pessoa surdocega pode desenvolver, envolvendo ou não a linguagem convencional escrita e falada. Segue a breve descrição de algumas dessas possibilidades:

Língua Brasileira de Sinais (Libras): utilizada pelas pessoas surdas e adaptada à condição visual do surdocego. Observando-se aspectos como distância e posicionamento para a apresentação dos sinais. Caso seja cegueira, os sinais são realizados na mão do surdocego.

Alfabeto dactilógico: também chamado de alfabeto digital ou alfabeto manual do surdo digitado na mão da pessoa surdocega, que pela articulação ou posição dos dedos percebe o sinal que está sendo formado e decodifica a letra.

Braille digital: o Braille digitado no corpo da pessoa surdocega, mas precisamente nos dedos.

Escrita alfabética na palma da mão: as letras do alfabeto são traçadas na palma da mão da pessoa surdocega.

Tadoma: a percepção da vibração e articulação das palavras realizada pela mão do surdocego junto ao aparelho fonoarticulatório do falante.

Vale ressaltar que a escolha sobre o tipo de comunicação deve ser de responsabilidade da própria pessoa surdocega.

\section{O ATENDIMENTO EDUCACIONAL ESPECIALIZADO}

Atualmente no Brasil a Política Nacional da Educação Especial está organizada na perspectiva inclusiva pressupondo a inserção do aluno com necessidades educacionais especiais no sistema regular de ensino. A legislação brasileira 
orienta no documento Política Nacional de Educação Especial na Perspectiva da Educação Inclusiva que para essa ação pedagógica ocorrer adequadamente o sistema de ensino deve ofertar de forma obrigatória o atendimento educacional especializado (BRASIL, 2008). Esse atendimento pode ser oferecido na escola do aluno ou em centros especializados, no mesmo turno ou em turno oposto ao que o aluno frequenta a escola. $\mathrm{O}$ mesmo documento define as ações do atendimento educacional especializado como práticas de complementação e/ou suplementação da formação do aluno.

A criança com deficiência visual não necessita de adaptações significativas no currículo, mas precisa de recursos específicos, tempo, modificação do meio, procedimentos metodológicos e didáticos, além de avaliação adequada. O professor precisa entender como funciona a visão do seu aluno e para tanto precisa de informações da equipe especializada que deverá atuar junto a escola na perspectiva da inclusão. E, o mais importante, é que os conteúdos sejam tratados de forma que ele possa participar ativamente de todas as atividades e tarefas desenvolvidas pelos demais alunos. Para tanto, Gasparetto (2007) afirma que o professor deve buscar desenvolver, no aluno, atitudes ativas em relação ao processo de aprendizagem, bem como o espírito crítico e reflexivo, considerando as diferenças individuais.

É necessário que os professores que têm trabalhado com a inclusão educacional no sistema regular de ensino conheçam as possibilidades e diferentes necessidades apresentados por um aluno que apresenta baixa visão, para o recebimento de adequada assistência educacional. No entanto, isso não implica que esses educadores tenham de ser especialistas, mas que detenham conhecimento para atuar ao lado desses alunos. Reconhece-se que o professor do ensino regular não recebe em seu currículo de formação, preparo especial para lidar com alunos deficientes visuais. Por essa razão, sentem-se despreparados e, por isso, necessitam de informação sobre a capacidade visual e necessidades do aluno com baixa visão. (GASPARETTO, 2007, p. 49).

O que temos que levar sempre em consideração e nunca esquecer é que cada criança é única e singular e que apesar das generalizações as adaptações vão ser diferentes. Como exemplo dessas especificidades, podemos citar a situação do uso da bengala, ou o ensino da orientação e mobilidade: 
Estudiosos na área da deficiência visual orientam que esta atividade na infância traz benefícios diversos para o desenvolvimento da criança com deficiência visual, uma vez que, favorece para sua independência e autonomia, além de contribuir para a inclusão na escola regular. Segundo Bruno (2005, p. 8):

O programa de orientação e mobilidade e a introdução precoce da bengala são essenciais e pontencializam o desenvolvimento motor, cognitivo e social das crianças com DV e múltipla. Organiza e previne as alterações e desvios na postura e marcha; estimula o desejo de mover-se, de pesquisar e explorar o mundo. É o caminho para a independência, autonomia e inclusão em creches e pré-escolas.

Portanto, a participação precoce em programas de orientação e mobilidade é um aspecto de extrema importância para a criança cega, porque possibilita a interação com o ambiente, aspecto que trará subsídios para a inclusão escolar.

Abrahamsson (2004) destaca que o uso precoce da bengala traz benefícios, à medida que favorece para a aceitação da bengala pela criança, familiares e colegas. Portanto no período da intervenção precoce o objetivo central da orientação e mobilidade não será apenas a utilização de técnicas, mas a familiarização com a bengala pela criança seus familiares e, sobretudo pela comunidade.

Como destaca Bruno (1993) é de fundamental importância a introdução da bengala o mais cedo possível para que a criança possa incorporá-la a sua autoimagem, desenvolvendo uma relação positiva, significativa e funcional com este instrumento. E para a família, professores, amigos e colegas, a bengala deixará de ser objeto símbolo da cegueira, para tornar-se o instrumento de independência e autonomia.

Por esse motivo o programa de orientação e mobilidade deve ser desenvolvido de forma individualizada de acordo com o contexto de cada aluno, considerando a maneira como a pessoa com deficiência visual, seus familiares e professores percebem o seu desenvolvimento, para planejar atividades que estejam de acordo com suas necessidades. Por isso, o profissional de orientação e mobilidade tem uma função importante, uma vez que, precisa conhecer os espaços que o aluno frequenta e estabelecer uma relação de confiança com ele, seus familiares e professores para elaborar um programa que favoreça o desenvolvimento pleno do mesmo. 
A construção de adaptações curriculares para o aluno surdocego precisa considerar: em que momento do desenvolvimento as perdas aconteceram; o grau de comprometimento de cada perda; o acesso da criança ao atendimento especializado e o uso funcional das Tecnologias Assistivas ${ }^{7}$ mais adequadas a sua condição perceptiva particular.

Dentre as adaptações necessárias para o aluno surdocego vale ressaltar a importância do guia-interprete e do instrutor-mediador, que são profissionais especializados responsáveis por acompanhar individualmente a pessoa surdocega, conhecendo as peculiaridades da sua forma de comunicação. A depender do comprometimento das funções visuais e auditivas essa pessoa pode ter um papel maior ou menor na comunicação eficaz do surdocego com o ambiente em que vive. Farias e Maia (2007. p. 27) relatam que:

A inclusão é favorecida com a participação do profissional guiainterprete (quem faz a interpretação na forma predominante de comunicação do surdocego e é também o seu guia), esse profissional é necessário para a inclusão da pessoa surdocega póslinguística (quem adquire a surdocegueira após a aquisição de uma língua), ou um instrutor mediador (quem faz a interpretação e a intermediação das informações com o meio e a pessoa surdocega) para pessoas que são surdocegas pré-linguísticas (quem adquire a surdocegeuria antes da aquisição de uma língua), na qual a intermediação será a chave para o sucesso da aprendizagem e inclusão.

Com o avanço das Tecnologias Assistivas nas áreas de Informação e Comunicação, os alunos surdocegos têm a oportunidade de potencializar os seus resíduos visuais e auditivos e/ou facilitar o uso de sistemas de comunicação específicos, como o Braille e a Libras através de recursos tecnológicos. Noguer e Rey (2004) discutem diferentes propostas de ajuda tecnológica e organizamnas pelo tipo de acesso à comunicação que a pessoa surdocega vai ter: se via tátil, através por exemplo do Braille ou da vibração; se via visual, através da ampliação de letras, maior contraste, distância, luminosidade; se via auditiva, através das vozes, dos sons telefônicos, dos avisos sonoros. Por exemplo: um surdocego que tenha acesso ao mundo via vozes pode se beneficiar do o MIC 30 , um microfone que se conecta a prótese auditiva ampliando o som externo,

\footnotetext{
${ }^{7}$ São recursos, técnicas, metodologias que visam a autonomia da pessoa com deficiência.
} 
ou do Microlink que seria um receptor ligado a prótese auditiva conectado a um microfone emissor de FM por quem fala (um professor por exemplo) reduzindo os ruídos externos e potencializando a comunicação.

\section{CONCLUSÃO}

Entendemos que socializar informações antes retidas nas instituições especializadas é criar lastros para que a inclusão da criança cega e surdocega ocorra não só no âmbito da escola, mas também na rua, na igreja, no parque, na vizinhança. Garantir que as escolas possam melhorar a sua prática pedagógica, apropriando-se de técnicas eficazes no trabalho com o aluno deficiente é possibilitar que a vida escolar seja compartilhada desde a mais tenra idade, aprendendo-se coletivamente, no palco da escola, que os seres humanos são iguais numa única coisa: na diferença. Porque, lá no fundo, cada um é o que é, nem menos nem mais do que ninguém, um ser único, singular, dono de uma história individual construída na coletividade.

É fundamental, portanto, que as instituições especializadas redefinam as suas práticas, adequando-as ao paradigma inclusivo, estreitando a parceria com as organizações que estudam e implementam programas de formação para professores, desenvolvendo pesquisas conjuntas, conhecendo a produção científica atualizada sobre a práxis pedagógica, partilhando os conhecimentos acerca do desenvolvimento da criança cega e surdocega, favorecendo a aproximação entre o ensino comum e o especializado. Não é possível ocorrer, de fato, a inclusão da criança com deficiência se a educação especial e a educação comum se comunicam através de um muro de tabus e incompreensões, em que o fracasso é atribuído ao outro e o sucesso é visto como uma conquista pessoal.

\section{REFERÊNCIAS}

ABRAHAMSSON. R. A autonomia para a movimentação no ambiente e a independência para ir e vir: orientação e mobilidade para a criança pré-escolar cega ou com baixa visão. Laramara: São Paulo, 2004.

BRASIL. Ministério da Educação. Estratégias e orientações pedagógicas para a educação de crianças com necessidades especiais: dificuldades de comunicação e sinalização: deficiência visual. Brasília, 2002.

BRASIL. Ministério da Educação. Política nacional da educação especial na perspectiva da educação inclusiva. Brasília, 2008. 
BRUNO, M. M. G. Deficiência visual: reflexão sobre a prática pedagógica. São Paulo: Laramara, 1997.

Orientação e mobilidade na perspectiva do desenvolvimento integral. Laramara: São Paulo, 2005.

O desenvolvimento integral do portador de deficiência visual. São Paulo:

Newswork, 1993.

O significado da deficiência visual na vida cotidiana: análise das representações dos pais-alunos-professores. 1999. 157 f. Dissertação (Mestrado em Educação) Universidade Católica Dom Bosco, Campo Grande, 1999.

CEDER-NASCIMENTO F. A. A. A.; COSTA, M. P. R. Descobrindo a surdocegueira educação e comunicação. São Carlos: Edufscar, 2005.

COÍN, M. R.; ENRÍQUEZ, M. I. R. Orientação, mobilidade e habilidades da vida diária. In: MARTÍN, M. B.; BUENO, S. T. (Org.). Deficiência visual: aspectos psicoevolutivos e educativos. [S.1.]: Livraria Editora Santos, 2003. p. 249-261.

DESSEN, M. A.; SILVA, N. L. P. Intervenção precoce e família: contribuições do modelo bioecológico de Bronfenbrenner. In: DESSEN, M. A.; COSTA JUNIOR, A. L. A ciência do desenvolvimento humano: tendências atuais e perspectivas futuras. Porto Alegre: Artmed, 2005. p. 152-167.

GASPARETTO, M. E. R. F. A pessoa com visão subnormal e seu processo pedagógico. In: GASPARETTO, M. E. R. F.; MASINI, E. F. S. (Org.). Visão subnormal: um enfoque educacional. São Paulo: Vetot, 2007.

FARIAS S. S.; MAIA R. S. O surdocego e o paradigma da inclusão. Inclusão: revista de Educação Especial, Brasília, v. 4, 2007.

MAIA, S. R. A educação do surdocego: diretrizes básicas para pessoas não especializadas. 2004. 93f. Dissertação (Mestrado em Distúrbio do Desenvolvimento) - Universidade Presbiteriana Mackenzie, São Paulo, 2004.

MARTÍN, M. B.; RAMIREZ, F. R. Visão Subnormal. In: BUENO, S. T.; MARTÍN, M. B. (Org.). Deficiência visual: aspectos psicoevolutivos e educativos. São Paulo: Santos Editora, 2003.

MASINI, E. F. S Do sentido, pelos sentidos, para o sentido. Niterói: Intertexto, 2002.

NOGUER B. A.; REY, E. R. Ayudas técnicas para personas com sordoceguera. In: VIÑAS, P. G.; REY, E. R. La sordoceguera: um análisis multidisciplinar. Madrid: ONCE, 2004.

SACRISTÁN, J. G. A educação obrigatória: seu sentido educativo e social. Porto Alegre: Artmed, 2001. 


\section{ALGUMAS CONSIDERAÇÕES SOBRE OS CHAMADOS TRANSTORNOS COMPORTAMENTAIS}

Félix Díaz Rodríguez

\section{INTRODUÇÃO}

Como uma obrigação histórica transcendental ao melhoramento de suas sociedades, os governos e com eles seus sistemas de educação, devem avaliar e valorizar o percurso educativo na formação da personalidade cidadã de seus nacionais, tornando-se imprescindível reanalisar os objetivos relacionados com tal formação, o que foi alcançado e o que falta alcançar, assim como as medidas necessárias em termos de prevenção e intervenção diagnóstica, terapêutica e de seguimento.

Desta forma, se reintegram os sucessos e se redesenham as metas frustradas elaborando novos objetivos de permanência e/ou mudanças de estratégias de acordo com a nova realidade que se analisa, incluindo todas as categorias populacionais correspondentes às faixas ditas "normais" como também aquelas relacionadas com algum desvio biológico, psicológico e/ou social.

Um fato conhecido e sofrido por todos é o alarmante crescimento da violência de todo tipo, desde os atos mais simples e aparentemente inocentes até os mais hediondos e abomináveis consumados contra as pessoas e/ou contra patrimônios, bens e serviços privados e públicos, individuais e sociais e ao meio ambiente nos quais progressivamente participam menores de idade numa esca- 
lada não proporcional as faixas etárias envolvidas: nessa violência desenfreada cada vez mais os infratores têm menos idade.

Entre estes últimos, como pré-vitimários ou vitimários esporádicos ou permanentes (que ao mesmo tempo também são vítimas), encontramos uma significativa porção de crianças e adolescentes que conjuntamente com jovens e adultos cometem atos antissociais contra pessoas, grupos e instituições, muitos deles juridicamente delitivos, têm, ainda, no percurso formativo de sua personalidade algum tipo de desvio.

Assim, com estes antecedentes, os problemas relacionados com os denominados transtornos comportamentais são, às vezes sem denominá-los dessa maneira, os mais preocupantes para pais, professores, comunidades, autoridades e sociedade em geral por constituir a base destas condutas consideradas antissociais na sua consideração mais grave, fundamentalmente relacionadas com a delinquência ou na sua acepção menos grave inerente ao comportamento escolar.

Embora haja uma preocupação generalizada, a literatura especializada, assim como os currículos acadêmicos e a ação profissional em geral, não aborda esta problemática, pelo menos de forma suficiente e principalmente de maneira metodológica que possa servir como orientação para intervir de maneira preventiva, terapêutica e de seguimento neste setor tão importante da população que tanto repercute na dinâmica das relações sociais em termos de cidadania.

Nestas curtas linhas que condiciona um artigo, torna-se impossível valorizar e aprofundar os diferentes aspectos relacionados com esta orientação familiar, escolar e social que destacamos. Desta forma, nos centraremos em apontar, ainda que sem uma análise minuciosa, alguns problemas destacando-os para análises posteriores e principalmente, com a intenção consciente e dirigida de influir sobre eles, tanto em sua base geradora para preveni-los assim como no transtorno mesmo uma vez instaurado, para evitá-lo, modificá-lo e corrigi-lo em aras de uma inserção adequada à sociedade como vias de inclusão social. Acreditamos que tal integração só se potencializa quando a própria sociedade cria e instrumenta, aplica e facilita as condições apropriadas, científicas e humanistas, para que este portador se incorpore a ela com os requerimentos exigidos pela sociedade através de uma educação-reeducação pertinente e permanente.

E assim, sem ambição desmedida, trataremos alguns problemas relacionados com os transtornos de comportamento. 


\section{DE SUA DEFINIÇÃO}

Para analisar, de maneira geral ou particular, os denominados transtornos comportamentais, ou seja, ao nos referimos a eles de forma genérica, sindrômica, ampla, informativa ou com referência a alguma de suas características tipológicas, sintomáticas ou terapêuticas, é necessário esclarecer o que é um transtorno de comportamento, ou seja, definir o fenômeno ao qual nos referimos e, a partir daí, realizar os estudos correspondentes.

Com este alvo, primeiro devemos apontar que os chamados transtornos comportamentais (ou transtornos conductuais) também são denominados na literatura universal como transtornos emocionais, psicopatias ou sociopatias e também são conhecidos no Brasil como comportamentos típicos; embora o que melhor os caracteriza de forma diferencial é a denominação que utilizaremos: transtornos comportamentais.

Para aproximarmos adequadamente ao conceito de transtorno comportamental, devemos partir de uma clara diferenciação entre o que podemos considerar como um "desvio normal" e um "desvio anormal", ou seja, patológico.

Consideramos como "desvio" tudo aquilo que não corresponde a uma resposta adequada por parte do sujeito, quer dizer, a alteração de algum fenômeno, processo, mecanismo etc., e de acordo com seu grau de alteração no comprometimento funcional quantitativo e qualitativo, poderá ser "normal" ou "patológico".

Assim, podemos definir como desvio normal do comportamento aquelas ações que a criança realiza e que atrapalham sua dinâmica comportamental num contexto específico devido a determinadas circunstâncias pessoais ou extrapessoais e que não implicam mudanças negativas - pelo menos signifcativas " na personalidade da mesma. Alguns exemplos são: comportamentos específicos de indisciplina na sala escolar devido à falta de atividade escolar, desinteresse do aluno, ausência de regras e limites, rejeição ao professor, intolerância à disciplina ministrada desmedidamente, chamar a atenção de colegas etc., situações estas que tão pronto muda a situação, imediatamente muda tal comportamento.

Já quando falamos de um desvio patológico do comportamento, tal conduta ultrapassa as condições ambientais, ou seja, as ações desviadas se produzem sem uma situação interna e/ou externa que a estimule de forma imediata; mais bem, constitui um conjunto de ações estereotipadas que "se dão porque 
sim", não importa se existe uma razão para que aconteçam, se produzem independentemente da existência de uma causa (agredir a um colega por gosto por exemplo) e no caso de existir alguma causa, a reação é exagerada (agredir ao colega por este não atendê-lo imediatamente).

No caso que nos ocupa, o transtorno comportamental constitui uma resposta "anormal" que se dá numa parte de um setor populacional: determinado percentual de menores no grupo de menores de idade.

Como em qualquer intento definitório, no transtorno de comportamento encontramos diferentes conceitos e por suposto, alguns melhores que outros. De maneira simples, todos sabemos que se trata de comportamentos não correspondentes a determinadas regras pessoais-sociais próprias de determinadas idades infanto-adolescentes que determinam um "choque" entre tais condutas e as condutas ideais normatizadas pelos pais, pela escola, pela comunidade, em concordância com os padrões também ideais consensualizados pela sociedade.

Assim, é a referência social o critério para definir o que é transtorno ou não a partir de padrões de conduta estáveis relacionadas com a aceitação e o cumprimento das regras estabelecidas na sociedade ou de sua não aquisição e não cumprimento segundo a idade do sujeito.

É certo que cada sociedade tem suas características próprias no percurso histórico da humanidade, onde cada vez mais as sociedades humanizam as relações interpessoais o que não quer dizer que já possamos falar de sociedades "superiores" neste contexto. Esta idealização ainda continua sendo uma utopia.

Existem muitas definições de transtorno do comportamento, algumas mais precisas que outras, portanto, tratando de integrar estes diferentes critérios conceituais, proponho definir de forma sucinta o transtorno comportamental como um "desvio patológico do comportamento devido à ausência ou distorção dos padrões motivacionais orientadores do comportamento pessoal-social estabelecido pela sociedade onde o sujeito está inserido".

Para compreender por que dizemos que se trata de um desvio patológico do comportamento, primeiro temos que lembrar que chamamos comportamento o conjunto de manifestações de nossa psique, ou seja, comportamento é a exteriorização do que pensamos, memorizamos, percebemos, desejamos, necessitamos, sentimos... Assim, nosso mundo psíquico interior passa ao mundo externo com o qual nos relacionamos (com nossos semelhantes, com o meio natural e social) às vezes de maneira consciente, voluntária e às vezes inconscientemente, de maneira involuntária. 
Portanto, nosso comportamento está regido pelos processos psicológicos internos e assim, quando algum destes processos está alterado também se altera seu comportamento: produz-se então um desvio comportamental externo que responde a um desvio psíquico, interno. Quais são estes desvios psíquicos, internos no sujeito? Todos os especialistas interessados no tema concordam, em essência, que o desvio essencial se produz em nível motivacional, isto é, na construção e no desenvolvimento dos motivos pessoais que têm a ver com o relacionamento social (com pessoas, situações, bens, instituições etc., com as quais convive cada indivíduo).

Como se sabe, os motivos são aqueles interesses que toda pessoa seleciona para alcançar algo que satisfaça alguma necessidade sua, seja biológica (saciar sua fome, por exemplo), psicológica (estudar para ter conhecimentos, por exemplo) ou social (obter reconhecimento na sua comunidade), portanto, tais motivos têm como função, estimular, dirigir e manter o comportamento (ainda que em situações difíceis).

Esclarecemos que os motivos que o ser humano forja em suas relações sociais a partir de sua experiência individual e grupal são de natureza pessoalsocial. Mas o que quer dizer isto? Quer dizer que embora independentemente cada um de nós procura a satisfação de suas necessidades particulares, tal satisfação se produz no contexto de nossas relações interpessoais, ou seja, buscamos uma meta pessoal, de desfrute próprio porém sem afetar aos demais, sem privar aos outros psiquicamente ou fisicamente, moralmente ou materialmente dos direitos que nós também temos.

Assim, cada um de nós estrutura e reestrutura seus diferentes motivos, os ordena hierarquicamente no seu sistema motivacional atendendo a um grau de importância, de necessidade, de imediatez etc. assim, quando existe uma educação adequada e uma socialização correta, tal pessoa estrutura e organiza estes motivos considerando seu ambiente social. Isto significa que o indivíduo atribui o valor que realmente tem o convívio em grupo, o respeito à diversidade, a tolerância mútua, a significação da solidariedade e a colaboração interpessoal. Desta forma, a pessoa estabelece suas estratégias para alcançar o desejado sem afetar, pelo menos conscientemente, os direitos morais, físicos e de propriedade que têm os demais. Quando a pessoa, de alguma maneira, fere tais direitos, se produz nela o arrependimento e a reparação dos danos ocasionados ou o pedido sincero de desculpa, reconhecendo conscientemente a falta cometida.

Quando acontece o contrário, estamos de frente a um desvio importante do comportamento, que no caso de crianças e adolescentes se conhece como 
Transtorno Comportamental. Este transtorno requer uma reeducação onde se conscientize ao menor do incorreto de sua conduta e lhe seja ensinado mecanismos para modificar essa hierarquização errônea na qual prevalece seu individualismo, seu egoísmo, e onde o que importa é "ele" por sobre os demais e, portanto, para alcançar seus fins, atropela aos outros, sem remorso, sem sentir culpa, porque primeiro é "ele" e o que é "dele".

Claro que quando estes comportamentos desviados não são detectados a tempo e também quando não se intervém sobre eles de forma reeducativa, os mesmos tendem a agravar-se, individualizando-se ainda mais a hierarquização de motivos apontada. Como consequência, originam-se ações cada vez mais incoerentes no relacionamento interpessoal aprofundando-se o antagonismo entre o indivíduo e as normas socialmente estabelecidas e entrando num franco enfrentamento com a sociedade, ao extremo de que, quando o sujeito deixa de ser adolescente para converter-se num adulto jovem, se produz a conversão de transtorno de comportamento (próprio de crianças e adolescentes) para transtorno de personalidade (próprio de adultos) de tipo psicopático com o conhecido saldo patológico de frieza afetiva e comportamento antissocial presente nelas.

Quanto à causa do mecanismo psicológico que produz o Transtorno Comportamental (hierarquização inadequada dos motivos pessoais-sociais) lembremos que na definição que apresentamos diziamos: "devido a ausência ou distorção dos padrões motivacionais orientadores do comportamento pessoalsocial". Revisemos estes dois momentos causais em continuação.

Primeiramente, quando falo de "ausência", estou destacando que no próprio desenvolvimento psicossocial da criança, antes de estruturar sua personalidade " aos 3 anos de idade, durante ou depois “, não são apresentados padrões adequados de comportamento aonde pouco a pouco à medida que vai amadurecendo neurológica e psicossocialmente, ela possa ir aprendendo que suas satisfações devem respeitar o direito alheio. De tal forma, ao faltar normas para serem imitadas, a criança constrói de maneira espontânea, sem orientação, a partir de sua experiência imatura, suas próprias normas sem ter a contrapartida necessária.

Num segundo lugar, a mesma sequela psicossocial acontece com a criança e o adolescente que recebe a influência de seus conviventes (família, colegas, grupo, comunidade etc.), porém de forma distorcida, isto é, recebendo padrões que não levam a mensagem adequada de convívio pessoal-social, mas ao contrário, se lhe oferecem normas "negativas" de tal relacionamento, marcadas pela individualidade, pelo egoísmo, pela "lei do mais forte"; tal é o caso de 
adultos e menores de maior idade que ele e incluso coetâneos que assumem atitudes e condutas não compatíveis com o convívio grupal (familiar, escolar, social) ou condutas antissociais, incluindo asdelinquênciais, que bem pronto e de maneira espontânea (porque ele mesmo quer) ou de maneira obrigada (por pressão do outro ou do grupo), o menor se identifica e imita.

Os problemas de identificação destes padrões "negativos" e sua correspondente imitação comportamental constitui um processo psicossocial complicado, pois às vezes, os fatores influentes são muito fortes, como é o caso de comportamentos maternos, paternos, de irmãos, de amizades, de pessoas próximas e às vezes idealizadas, que exercem uma grande autoridade afetiva que compromete o menor impedindo qualquer ruptura com este tipo de vínculo, pois se sentiria "um traidor".

Outras vezes, esta identificação se impõe à força, utilizando a ameaça ou a agressão ou um falso compromisso moral (irmandade, grupo, ideologia etc.) que constituem "pregos" obstaculizadores para abrir a porta da independência e andar a procura da integração à sociedade.

Tratando-se de fortes influências "negativas" a linha educativa-reeducativa se baseia em contrapor influências "positivas" mais fortes através de diferentes estratégias de ação para com a família, a comunidade, a escola e com o próprio menor, o que não resulta uma tarefa fácil tanto subjetiva como objetivamente, pois a escola mesma é uma instituição que tradicionalmente "entra" na vida da criança tardiamente encontrando-se já com a identificação afetivacomportamental "negativa" apontada e por outro lado, a influência da escola atual se centra mais no acadêmico que no educativo propriamente dito, por diversas causas (justificadas e não justificadas) que a privam desse papel orientador-reorientador determinante.

\section{DE SUA CLASSIFICAÇÃO}

Os denominados transtornos comportamentais não apresentam as mesmas características no comportamento e tais diferenças estão dadas por fatores que nesta oportunidade proponho considerar como fatores de grau e fatores tipológicos.

a) Quanto às diferenças de grau, existem fatores como idade, influência externa (física-ambiental, socioeconômica, grupal, familiar, cultural, instrutiva etc.), conformação interna (neurológica, personalidade etc.) que determinam esses graus diferentes de sua manifestação antissocial. 
Com respeito a tais graus de afetação podemos classificar este grupo nas categorias de leve-moderada-severa, agrupamento que constitui um elemento valioso no diagnóstico para a compreensão e análise de sua caracterização e, portanto de sua terapêutica diferenciada.

Devemos entender como grau leve aquele subgrupo produtor de indisciplinas significativas, quer dizer, indisciplinas com causas não aparentes, frequentes, indiscriminadas, não situacionais etc., diferenciando-se daquelas indisciplinas comuns na maioria dos escolares que os professores reclamam quase diariamente nas aulas porém possíveis de eliminar, neutralizar ou controlar com determinadas medidas psicopedagógicas ou regulamentais simples.

Estas condutas não são perigosas (para ele e o resto das pessoas ou bens particulares ou alheios), pois não incluem danos físicos e/ou psicológicos (ao menos lamentáveis) embora afetem de algum modo seu próprio desenvolvimento pedagógico e psicossocial e dos demais na sala de aula, lar ou comunidade, manifestando condutas de inadaptação social que não se eliminam com a atenção habitual. Contudo, não comprometem grandemente a potencialidade da aprendizagem psicossocial do menor e, portanto, podem mudar com uma atenção psicopedagógica e familiar mais dedicada, na própria sala de aula ou do lar, e/ou fora de ambos contextos. Podemos incluir nestas condutas a falta regular de respeito, a rispidez no relacionamento com os demais, as fugas frequentes (da escola, da casa), sua rejeição constante a qualquer tipo de ensino, sua desmotivação estável pela aprendizagem etc.

$\mathrm{Na}$ categoria moderada, incluímos aqueles comportamentos intermediários entre leve e grave, quer dizer, um subgrupo considerado de alta periculosidade, pois as condutas que habitualmente se seguem ultrapassam o nível anterior (leve) e indicam uma deterioração progressiva de sua personalidade já que é similar às condutas tipificadas como crime pela lei (furtos, roubos, agressões físicas e/ou psicossociais etc.), o que potencialmente representa um grande risco futuro, pois podem converter-se num tipo severo. Estes menores são capazes de aceitar as propostas terapêuticas, porém para que tais medidas psicopedagógicas e sociais modifiquem realmente suas distorções comportamentais é necessário um regime de exigência maior que o utilizado com as leves pelo que geralmente se precisa de condições tipicamente especiais para sua atenção.

Nos transtornos correspondentes à categoria severa, o declive psicossocial é grave, a personalidade está fortemente deteriorada e sua disfunção antissocial se manifesta em comportamentos muito estáveis ("vive” para delinquir) e são 
francamente agressivos em extremo com relação às normas socialmente estabelecidas: sua conduta habitual constitui fatos de alta e real periculosidade social num nível "fortemente" sancionado pelas leis e também altamente intolerável pela comunidade por estar acompanhados geralmente por frieza, cálculo, plena consciência, inescrupulosidade, grande dano etc. Como é de se supor, a modificação é mais lenta, pois são menores com transtornos muito resistentes ao tratamento psicopedagógico e social a partir da força de suas convicções (erradas) pelo que as condições de intervenção devem ser muito especializadas e num tempo maior de atuação.

Geralmente na sala de aula nos encontramos com os casos leves e ainda, moderados, pois geralmente os casos severos abandonam a escola para "dedicarse” às atividades delitivas a não ser que de maneira oportunista assistam às aulas dentro de sua estratégia antissocial, realidade que não descarta alguma exceção da regra, principalmente naqueles menores que estão lutando conscientemente entre "o bem e o mal", circunstância esta que quando é detectada, deve ser aproveitada para reforçar a influência reeducativa.

Todos os casos demandam uma preparação "especial" tanto de condições como de especialistas e estratégias corretivas. Além disso, a intervenção deve ter um marco filosófico e de ação preferencialmente educativo, onde se privilegie um convencimento racional aceito com compromissos afetivos sinceros para visar uma reestruturação consciente e plena dos valores inadequados.

b) Desde o ponto de vista tipológico, os transtornos comportamentais constituem um grupo amplo e bem heterogêneo de síndromes, pois se é certo que em todos eles existe uma homogeneidade gnosiológica por compartilhar a mesma característica etiológica (educação inadequada), o mesmo mecanismo psicossocial (hierarquização motivacional inadequada) e a mesma manifestação (comportamento pessoal-social inadequado), também podem agrupar-se segundo suas características psicogenéticas as quais se correspondem sintomas bem específicos dentro do espectro das relações sociais.

Geralmente, tanto na fala popular como na atenção profissional, os transtornos comportamentais costumam ser reduzidos a um tipo "arquiconhecido": o Transtorno de Déficit Atencional com Hiperatividade (TDAH).

Este reducionismo constitui causa e efeito de uma pobre dedicação nos últimos tempos ao resto dos transtornos comportamentais, tão importantes e frequentes como os próprios TDAH, e, como costuma acontecer nestes privilégios, no redor dos TDAH existem algumas imprecisões como é por exemplo, com respeito a sua própria denominação como TDAH: o que é primário, a 
disfunção atencional ou a hiperatividade? Sempre há acompanhamento atencional nahiperatividade? Sempre que há inatenção se produz hiperatividade? Estas perguntas tentam um esclarecimento que por falta de espaço não farei nesta oportunidade.

Assim, integrando diferentes critérios autorais, alguns deles clássicos, podemos enumerar os diferentes tipos de transtornos comportamentais, o que não exime a possibilidade de existência de outros tipos:

- Hiperatividade com e sem déficit atencional (aqui se incluem os TDAH);

- Isolamento generalizado (timidez e reação esquizóide);

- Inadaptação neurótica;

- Reação de fuga;

- Reação fóbica;

- Agressividade não socializada;

- Roubo generalizado;

- Deprivação sensorial e/ou afetiva;

- Transtornos psicossexuais;

- Reação sociopática (delinquência).

Seguindo nosso objetivo de fazer somente algumas colocações gerais do problema unido ao fator de circunscrevermo-nos a umas poucas páginas, não caracterizaremos cada um destes tipos que pode fazer-se desde o ponto de vista etiológico, sintomático, preventivo, diagnóstico e terapêutico. Portanto, somente queremos destacar que, cada um destes tipos de transtornos comportamentais, além de sua homogeneidade grupal mantém sua heterogeneidade específica que lhes dá uma unicidade própria que torna imprescindível considerar seu estudo diferenciado.

\section{DE SUA INTERVENÇÃO}

Sem considerar as diferenças de grau e tipologias apontadas anteriormente, abordarei de maneira geral o tratamento dos transtornos comportamentais, isto é, o comum que deve ser considerado em todos eles. 
Assim, quando pensamos em como intervir nesses transtornos comportamentais, tanto antes de manisfestarem-se (prevenção) como quando já estabeleceram-se (tratamento), devemos diferenciar medidas diretas e imediatas e medidas indiretas e mediatas.

No primeiro caso me refiro às ações dirigidas ao problema mesmo, quer dizer, de atuar na modificação do comportamento inadequado principalmente do menor e também de seu meio de influência negativa, através da orientação, da reeducação, de medidas cautelares e incluindo as punitivas.

No segundo caso, faço referência às ações relacionadas com o melhoramento de vida tanto do menor como de sua família, comunidade e sociedade em geral gerando condições de escolarização, educação, cultura, esporte, saúde, emprego, moradia, saneamento básico, lazer etc., ou seja, um conforto social elementar, paulatino e progressivo, que satisfaça as necessidades pelo menos primárias do contexto dessa população em risco ou já desviada.

Quanto difícil resulta atuar numa ou outra direção! A tarefa poderá converter-se numa verdadeira façanha, porém não numa utopia irrealizável. Acho que em nossa população majoritária já existe uma consciência social do problema e de sua envergadura, agora só basta fundamentar de forma científica e humanista os passos a seguir, habilitar-nos tecnicamente e estabelecer uma metodologia de curto, médio e longo prazos, organizar-nos e centrar as forças e recursos sem paixões estreitas e ganhos políticos.

Lamentavelmente, no Brasil a preparação "especial” para cumprir estes objetivos geralmente é incompleta, insuficiente e/ou tergiversada (incluindo a própria família e comunidade), e quando estes menores não desfrutam da "liberdade" da rua, os locais institucionais onde geralmente se encontram geralmente reclusos (não incluídos), principalmente os menores contemplados nas categorias moderadas e severas, não são centros que possam considerar-se "educativos". O que ocorre é que muitas vezes, suas condições e seus programas não são verdadeiramente reeducativos e somente seguem uma orientação judicial-punitiva com suas implicações que na maior parte das ocasiões são contraproducentes para o desenvolvimento adequado destes menores infratores.

Ao anteriormente expressado se adiciona o fato de que muitas destas crianças e adolescentes portam um desvio grave ou com uma elevada tendência a tal gravidade, como se se encerrassem numa couraça de ferro. Consciente e inconscientemente são reticentes a qualquer mudança de seus hábitos comportamentais e rejeitam a aproximação social isolando-se individualmente 
ou em seu grupo "negativo" procurando reforçar suas atitudes antissociais, tornando difícil a ação terapêutica e principalmente o trato com eles num plano colaborativo.

Pessoalmente acredito que na realidade brasileira há caminhos trilhados neste campo onde algumas ações podem ser mantidas e outras podem ser reconsideradas, e que, portanto, existe uma experiência com sua memória baseada em sucessos efetivos e eficientes que resultam em fatos importantes, porém ainda insuficientes.

\section{CONCLUSÕES}

1- O grupo que denominamos transtornos comportamentais inclui os desvios comportamentais mesmos, ou seja, os comportamentos inadequados resultantes da disfunção do sistema motivacional pessoal-social do menor e que chamamos comportamentos primários e não aqueles comportamentos também desviados porém produto de outras alterações orgânicas (deficiência mental por exemplo), psicológicas (neuroses por exemplo) e sociais (fanatismo ideológico por exemplo) e que portanto, são denominados comportamentos secundários.

2- Um procedimento pedagógico e psicopedagógico de qualidade técnica e humana que assegure uma instrução acadêmica e uma educação atitudinal adequados na escola, assim como condições positivas de educação social em geral, podem prevenir e eliminar a formação e agravamento dos transtornos comportamentais.

3- Devem ser revistas as inúmeras estratégias preventivas, de diagnóstico e terapêuticas com seus métodos, técnicas, instrumentos e recursos existentes que permitem modificar os motivos, as atitudes e os comportamentos inadequados desta população.

4- Na educação e reeducação dos transtornos comportamentais não bastam os esforços educativos e/ou reeducativos isolados de pessoas e instituições; é imprescindível o conserto de intentos mancomunados para tornar as normas ideais socialmente estabelecidas a fonte determinante do comportamento cidadão que necessita da sociedade para o desenvolvimento integral e harmônico de sua comunidade. 


\section{REFERÊNCIAS}

COLL, César; MARCHESI, Alvaro; PALACIOS, Jesus. Desenvolvimento psicológico e educação. Porto Alegre: Artmed, 2004.

HERBERT, Martin. Transtornos de la conducta en la infância y en la adolescência, Buenos Aires: Editorial Barcelona, 1983.

NUNES SOBRINHO, Francisco de Paula; CUNHA, Ana Cristina Barros da (Org.). Dos problemas disciplinares aos distúrbios de conduta: práticas e reflexões. Rio de Janeiro: Dunya Editora, 1999. 



\section{PANORAMA DA CLASSE HOSPITALAR NO MUNDO}

Alessandra Barros

\section{INTRODUÇÃO}

A existência de professores e espaços de ensino-aprendizagem nas enfermarias de hospitais que atendem crianças e adolescentes tem sido amplamente afirmada como um direito destes indivíduos, face à inegável contribuição que esta modalidade de atendimento lhes presta ao desenvolvimento integral, quando este se encontra sob situação de risco (FONSECA, 2002; JIMÉNEZ; GOMEZ; HERNÁNDEZ, 2002). Quando associada à melhora do estado clínico e ao aumento da adesão aos tratamentos médicos, a existência de escolas nos hospitais é, então, também afirmada em suas funções terapêuticas (ONTES; FONTES, 2003). Quando associada ao favorecimento da continuidade dos estudos e da aquisição de habilidades e competências esperadas para a idade do jovem paciente, a escola hospitalar é assinalada em suas funções educativas e, por esta via, reafirmada como um direito (UNESCO, 2006).

Aqueles professores que trabalham ou já trabalharam junto a crianças e adolescentes hospitalizados bem sabem o que pode vir a significar, no limite, a expressão desse direito (FONTES, 2005). Algumas vezes, quando o prognóstico que se anuncia é o óbito, a meta mais próxima a ser atingida não é a conclusão de um ciclo de estudos, mas somente, e nem por isso apenas, o exercício inalienável do que se chama simplesmente de um direito: aquilo que nos iguala em oportunidades. Direito que numa concepção instrumental de educação, voltada para demandas imediatas de formação para o trabalho, talvez seja interpretado quase como um capricho. 
O que proponho neste artigo é que experimentemos medir, para cada país, a cobertura de escolas hospitalares: esta singular e significativa expressão da prioridade à infância e da assunção da educação como princípio humanizador.

$\mathrm{O}$ que sugiro daqui para frente são modos de operacionalizar essa medida, não na forma pronta de uma equação, mas ao menos nas premissas analíticas que permitiriam o cotejamento deste peculiar indicador de justiça social.

\section{DESENVOLVIMENTO}

Neste sentido, inicio esclarecendo que tal cobertura presume, antes de tudo, a densidade de escolas hospitalares. Por densidade deve entender a relação entre o número absoluto destas e a população de um país. Tornar um valor apreciável a partir de uma razão de proporção permite corrigir discrepâncias extremas quando da comparação deste valor com outros. Assim, ao comparar-se, por exemplo, a quantidade de escolas hospitalares existentes na Finlândia com a quantidade daquelas existentes no Brasil, partiríamos do número absoluto, mas compararíamos o número relativo. Assim, não incorreríamos no erro de julgar que a Finlândia, porque tem 33 escolas hospitalares, estaria dedicando um investimento menor à escolarização em hospitais do que o Brasil, que tem 112 destas $^{1}$, considerando-se que a população do Brasil é de 180 milhões de habitantes e a da Finlândia é de apenas cinco milhões. Assim, não seria possível dizer, tão apressadamente, que a Finlândia tem um número menor de escolas hospitalares à disposição de suas crianças e adolescentes hospitalizados.

Esse princípio necessário de ponderação dos valores absolutos das escolas hospitalares, quando da comparação de um país com outro, requer, ainda, a consideração de que diferentes países ao redor do mundo possuem perfis demográficos bastante diversos uns dos outros. Assim, pois, enquanto o Brasil possui cerca de $30 \%$ de sua população na faixa etária de zero a 19 anos (IBGE, 2007), a Finlândia possui apenas 18\% (LIZASOÁIN RUMEU; OCHOA LINACERO; SOBRINO MORRÁS, 1999). Desse modo, melhor ainda se faz, se ao compararmos um país com o outro no que tange à oferta de escolarização em hospitais o fizermos tendo em conta a proporção estimada de jovens de cada país.

\footnotetext{
${ }^{1}$ Os números de escolas hospitalares do Brasil e da Finlândia foram atualizados com base em trabalhos apresentados no 6th Congress of HOPE on Hospital Education, realizado em Tampere, Finlândia em junho de 2008.
} 
Assim, o Brasil, com seus 54 milhões de adolescentes e crianças em idade escolar, talvez não possua mesmo tantos espaços de escolarização em hospitais quanto a Finlândia, que dispõe de 33 escolas para um contingente potencial de jovens pacientes oriundos de um universo de pouco menos de um milhão de crianças e adolescentes. Em verdade, esta rápida comparação nos diria que a Finlândia tem, proporcionalmente, quase 16 vezes mais escolas hospitalares que o Brasil.

Um maior refinamento interpretativo desta comparação deverá levar em conta, também, que diferentes países, independente do tamanho de sua população jovem, hospitalizam mais ou menos crianças e adolescentes. Assim o fazem, principalmente, em razão da oferta de leitos, no caso em questão, leitos pediátricos. De modo geral, quanto maior a oferta de leitos, maior a probabilidade de internação. No Brasil, existem cerca de 60 mil leitos pediátricos hospitalares (BRASIL, 2006), os quais, todavia, têm sido progressivamente reduzidos devido à falta de recursos para manutenção, insumos e profissionais.

Contudo, deve-se entender por oferta de leitos, não somente a simples existência física destes, mas, também, o acesso, no sentido da gratuidade. Assim, pois, no Brasil, 63\% das internações totais são realizadas em hospitais públicos e $36,6 \%$ em hospitais privados (ORGANIZACIÓN PANAMERICANA DE LA SALUD, 2007). Mas o acesso, no sentido da proximidade geográfica é igualmente relevante. Assim, mesmo distâncias muito pequenas, que ainda têm embutidas despesas de transportes para as famílias, provocam importantes reduções na probabilidade de atendimento.

Além de considerar as instituições hospitalares, propriamente ditas, quando da apreciação das possibilidades de internação de um indivíduo, devem-se levar em conta, ainda, características da rede de assistência à saúde, no sentido mais amplo, de um país. Isto é posto porque o atendimento em serviços de atenção básica - postos de saúde, ambulatórios e programas de saúde da família - cumpre o papel de identificar e encaminhar demandas para internação hospitalar, que de outro modo não seriam assistidas (CASTRO, 2006; OLIVEIRA; TRAVASSOS; CARVALHO, 2005). Nestes termos, uma criança que chega a ser internada para a realização de um procedimento cirúrgico no coração, por exemplo, assim o foi porque, antes de qualquer coisa, teve tal demanda identificada. O atendimento em serviços de atenção básica pode, ainda, prevenir o surgimento e/ou evitar o agravamento dos problemas de saúde e, logo, reduzir a demanda dos serviços de maior complexidade - os hospitais. Assim, por exemplo, países que ofertam, com regularidade e qualidade, cobertura de 
assistência ao pré-natal e ao parto, o que não é o caso do Brasil, administram uma menor demanda de internações de crianças com paralisia cerebral, dentre outros agravos (CASTRO; TRAVASSOS; CARVALHO, 2005).

Todavia, a ocorrência de uma internação hospitalar é um evento ainda mais complexo do ponto de vista das variáveis que sofre influência. Além das características apontadas, que podem diferir significativamente de um país para outro, também o perfil epidemiológico de uma população é fator importante na conformação dos modelos assistenciais hospitalares.

Logo, pode-se dizer que diferentes países, independente do tamanho de sua população jovem, hospitalizam mais ou menos crianças e adolescentes em razão das diferentes doenças que acometem esta população, ou das diferentes taxas de incidência de uma mesma doença. Desse modo, distintos perfis de morbidade na infância e juventude determinam diferentes tipos e quantidades de internações hospitalares para cada país (NASCIMENTO; MOTA; COSTA, 2003). E, num contexto de concorrência por um número limitado de leitos, situação por que passam muitos países periféricos, a ocupação destes se dá pelas doenças mais prevalentes e/ou pelas de tratamento mais prolongado.

No Brasil, cerca de 400 mil crianças entre 5 e 9 anos e quase um 1 milhão e meio de adolescentes entre 10 e 19 anos foram internados em hospitais públicos no ano de 2005 (ORGANIZACIÓN PANAMERICANA DE LA SALUD, 2007). No Brasil, as causas de hospitalização mais frequentes de crianças entre 5 e 9 anos, são as doenças do sistema respiratório (que representam quase $30 \%$ das hospitalizações nessa idade) seguidas pelas doenças transmissíveis (representando 18\%), com ênfase para a diarréia e outras doenças infecciosas intestinais. Para os adolescentes do sexo feminino, as causas mais frequentes são complicações na gravidez ou no parto (70\%), doenças do aparelho geniturinário (5\%) e doenças do aparelho respiratório. Adolescentes do sexo masculino são internados em razão de lesões, fraturas e envenenamentos, provenientes de acidentes e violência (30\%), em razão de doenças do aparelho respiratório (12\%) e de doenças do aparelho digestivo (10\%).

Assim, voltando à comparação inicial que aproximou o Brasil e a Finlândia, podemos dizer que as crianças desse segundo país, além de, numericamente, representarem uma menor proporção quando comparadas à distribuição da infância na população brasileira, quando adoecem e são internadas assim o fazem muito mais pelo câncer, pela diabetes, pela asma e por algumas doenças crônicas, como a fibrose cística - bastante comum em populações brancas caucasianas. Estas enfermidades, embora também presentes num cenário como 
o brasileiro, competem pelas vagas nos leitos com as doenças mais típicas do perfil sanitário desse país, dentre as quais vale destacar, ainda, aquelas determinadas pela herança genética da população, neste caso a anemia falciforme, mais comum em populações afrodescendentes (SILVA; RAMALHO; CASSORLA, 1993; CANÇADO; JESUS, 2007).

Mesmo as diferenças culturais entre países carecem ser consideradas quando da comparação de seus perfis sanitários. Assim, pois, um país como o Brasil tem, para a faixa etária de 10 a 19 anos, alta incidência de internações decorrentes da gravidez (NASCIMENTO; MOTA; COSTA, 2003), não somente porque são deficitários seus programas de educação em saúde, como provavelmente, porque sua legislação não permite o aborto. Meninas francesas ou portuguesas, por outro lado, se chegam a engravidar na adolescência, não só podem optar pelo aborto, como não precisam realizá-lo clandestinamente, não submetendo sua saúde aos agravos dali decorrentes.

O planejamento e a gestão dos serviços de assistência hospitalar de um país devem, portanto, contemplar essas variáveis quando do dimensionamento da atenção à saúde e, no diálogo com o setor educação, prever a cobertura ideal de escolas hospitalares. Se o fazem adequadamente, então, pode-se dizer - com base em mais este indicador social - que seriam países justos do ponto de vista da garantia do direito incondicional à educação.

Entretanto, se queremos comparar países neste aspecto, é importante ressalvar que as distâncias em crescimento e desenvolvimento econômico que separam radicalmente os países centrais dos países periféricos podem tornar incomensurável um real investimento na oferta de escolarização em hospitais.

Logo, assim como para comparar ordens de grandezas diferentes é necessário ajustá-las a uma base comum, o que se segue, neste percurso explicativo que propõe a medida da densidade de escolas hospitalares como indicador de justiça social, é que assim o façamos a partir da segmentação dos países por grupos. Um primeiro grupo de países que teriam suas coberturas de escolarização hospitalar comparadas seria aquele cujo Índice de Desenvolvimento Humano (IDH ) se situasse na faixa de zero a 0,5 . O segundo grupo na faixa de 0,5 a 0,8 e o terceiro grupo de países comparados quanto à justeza da sua cobertura de escolas hospitalares seria aquele de IDH acima de 0,8 . O exercício comparativo partiria, assim, de contextos e conjunturas já estabelecidas de conquistas ampliadas em direitos de cidadania e equidade social. 
O Reino Unido, por exemplo, é um país que, tendo apenas 60 milhões de habitantes e uma pirâmide etária anômala para os nossos padrões, consegue contabilizar 30 escolas hospitalares, em parte porque não precisa destinar recursos para sanar mazelas sanitárias. No seu cenário de saúde não se debate mais problemas como a mortalidade infantil, ali reduzida a apenas cinco crianças que morrem antes de completarem um ano de idade, para cada 1000 nascidas vivas (LIZASOÁIN RUMEU; OCHOA LINACERO; SOBRINO MORRÁS, 2002). Além disso, porque reconhecem os direitos de cidadania de sua população, e dentre estes os direitos da infância, é que se obrigam a investir tanto nas condições que garantem os baixos índices de mortalidade infantil, quanto naquelas que levaram à extrema redução do analfabetismo, praticamente erradicado no Reino Unido.

Indicadores como o IDH e os escores do PISA, passam a ser, desse modo, manifestações redundantes dessa conjuntura. A grande disponibilidade de escolas hospitalares para a população infantil hospitalizada ganharia, igualmente, o peso de uma constatação óbvia. Entretanto, há de se conferir se, de fato, todas as nações que reúnem essas melhores e ideais condições econômicas e sociais, realmente cumprem o dever de assistir suas crianças integralmente.

Resultado de mobilização política e de uma conjuntura socioeconômica favorável, o fato de crianças doentes terem o direito de continuar aprendendo dentro de um hospital é, todavia, também causa, além de consequência das plataformas democráticas dessas nações. Na singeleza de seus números, que pouco representam quando se compara a cobertura normal de um sistema regular de ensino, essas escolas hospitalares fazem continuamente lembrar, aos cidadãos e aos seus representantes eleitos, os pressupostos implícitos que fundam aqueles programas de governos.

Daí, se as 30 escolas hospitalares do Reino Unido são ou não suficientes, há de se julgar a partir da comparação deste país com outros que usufruem de semelhantes condições infraestruturais e que nos termos aqui sugeridos, compartilham a mesma faixa de IDH. Assim o façamos, então aproximando o Reino Unido (IDH 0,928) à Finlândia (IDH 0,930) (OECD, 2006). Este segundo país, que para tornar fácil o cálculo, teve aqui sua população jovem estimada em 1 milhão de habitantes, tem 33 escolas hospitalares: o que representa cerca de onze vezes mais que as 30 escolas que o Reino Unido dispõe para os seus dez milhões de crianças e adolescentes.

Por conseguinte, ao invés de compararmos o Brasil à Finlândia, compararíamos o Brasil com a Venezuela, por exemplo. Esta aproximação nos diria, em 
princípio, que tendo a Venezuela cerca de 7,5 milhões de crianças e adolescentes, a suas 30 escolas hospitalares representam, em termos de cobertura, duas vezes mais que as 112 escolas hospitalares brasileiras representam para o Brasil nos seus 54 milhões de crianças e adolescentes.

Mas então, se comparamos dessa vez, o Brasil ao Chile, reafirmaremos o quão distante de um ideal de justiça social o Brasil se coloca em termos da oferta de escolas hospitalares, pois o Chile, com seus 4 milhões de crianças e adolescentes oferta, através de suas 25 escolas hospitalares, três vezes mais que o Brasil o faz.

Comparar países que estão dentro de uma mesma faixa de IDH nos levaria a aproximar a Argentina (IDH 0,844) e o Chile (IDH 0,867) ambos os países da América Latina, à Finlândia, mais uma vez, sob exemplo. $\mathrm{O}$ fato de o Chile ostentar excelente posição no ranking do PISA, o $1^{\circ}$ dentre todos da América Latina (OECD, 2006), nos insta a reafirmar a possibilidade de comparálo à Finlândia. Assim, pois, se em relação ao Brasil, o Chile demonstra possuir uma cobertura bem maior de escolas hospitalares, não o faz, por outro lado se comparado à Finlândia. Em relação a este país, o Chile e as 25 escolas hospitalares disponíveis para os seus 4 milhões de crianças e adolescentes ainda representam cinco vezes menos que as 33 existentes na Finlândia.

\section{CONSIDERAÇÕES FINAIS}

Cabe asseverar que esse exercício de aproximação entre países foi aqui apresentado apenas para breve ilustração do poder analítico da proposta. Ele não poderia prescindir, conforme os argumentos aqui expostos vêm sugerindo, de uma sofisticação analítica que agregasse a estes cálculos outros indicadores que, ao qualificarem as respectivas taxas de ocupação média dos leitos pediátricos, trariam melhor ajuste à comparação.

Nações que alcançam o sentido primeiro e talvez o mais verdadeiro da educação, a elegem em prioridade nas suas agendas de governo. Assim expressam quando a fazem uma opção incondicional, pois se negam a contingenciá-la a orçamentos insuficientes, metas de curto prazo ou quantificações intangíveis. Ofertam educação a todas as suas crianças indistintamente.

Como resultado de um percurso coerente de investimentos em saneamento urbano, em geração de emprego e renda, no combate a epidemias, na alfabetização das mulheres, na produção de divisas, mas acima de tudo, na busca por um equacionamento menos desigual dessas riquezas, essas nações alcan- 
çam um sucesso mútuo e retro alimentador na erradicação tanto de doenças quanto do iletramento. Por isso, quase fazem parecer, aos olhos das nações que não lograram romper a circularidade da relação pobreza, ignorância e exclusão social, que a implantação - em número suficiente - de espaços de ensino-aprendizagem em hospitais para crianças, é um luxo possível apenas para gestores públicos que já sanaram outras demandas mais urgentes.

Que assim o seja, o fato é que, na prática talvez este ideal esteja sendo cumprido mais por uns países do que por outros. Daí deriva, então, a necessidade da apreciação da cobertura de escolas hospitalares de cada país.

A mensuração que aqui se propõe, desde que nos termos que se sugere ajustar, vizibilizaria, ainda, o mérito eventual de um país no empenho em estender a sua cobertura de escolarização em hospitais, até então ocultada pela insuficiência de recursos para os setores saúde e educação, preponderantemente.

Aquela última estratégia de ajuste analítico aplicável ao indicador de cobertura de escolas hospitalares cumpriria, igualmente, o papel de evitar a culpabilização de países - muitos da América Latina e do Caribe - já vitimizados pelo endividamento e pela dependência econômica resultantes da submissão a paises centrais; atrelamento este que expressa o contraponto da riqueza e pujança material de muitas das nações europeias.

Corrigiria ainda, talvez, aberrações resultantes de situações nas quais um país, eventualmente possuidor de uma grande cobertura de escolas hospitalares, porque antes de tudo referido a um grande contingente de crianças e adolescentes doentes e internados, fosse concebido como um país justo.

Encerro esse artigo, clamando por uma maior união de esforços intelectuais entre pedagogos, sociólogos, sanitaristas, psicólogos, demógrafos, cientistas políticos, administradores, entre outros, no sentido da produção de mais iniciativas de macroanálise como esta e, principalmente, no sentido do aperfeiçoamento desta. A consolidação das escolas hospitalares no horizonte dos direitos de cidadania das crianças e adolescentes de todos os países depende, dentre muitas coisas, da capacidade daqueles que executam a escolarização nos hospitais e/ou a justificam teoricamente, de fazer ouvir a importância desta modalidade de atendimento. Importância esta afirmada tanto pela escolarização hospitalar em si mesma, quanto pelas contribuições que ela soma a outras instâncias e fóruns de proteção à infância e à juventude. 


\section{REFERÊNCIAS}

ALONSO, L.; GARCIA, D.; ROMERO K. Una experiencia de pedagogia hospitalaria con niños en edad preescolar. Educere, Meridad, v. 10, n. 34, p. 455-462, 2006.

IBGE. Síntese de indicadores sociais: uma análise das condições de vida da população brasileira. Rio de Janeiro, 2007. (Série Estudos e Pesquisas: informação demográfica e socioeconômica, 21).

BRASIL. Ministério da Saúde. Organização Pan-Americana de Saúde. Painel de Indicadores SUS. Brasília, 2006.

CANÇADO, R. D. ; JESUS, J. A. A doença falciforme no Brasil. Rev. Bras. Hematol. Hemoter, v. 29, n. 3, p. 203 -206, 2007.

CASTRO, M. S. M. Desigualdades sociais no uso de internações hospitalares no Brasil: o que mudou entre 1998 e 2003. Ciência \& Saúde Coletiva, v. 11, n. 4, p. 987-998, 2006.

CASTRO, M. S. M.; TRAVASSOS, C.; CARVALHO, M. C. Efeito da oferta de serviços de saúde no uso de internações hospitalares no Brasil. Revista de Saúde Pública, v. 39, n. 2, p. 277-84, 2005.

FONSECA, E. S. Implantação e implementação de espaço escolar para crianças hospitalizadas. Revista Brasileira de Educação Especial, v. 8, n. 2, p. 205-222, 2002.

FONTES, R. S. Educación hospitalaria: un recurso frente al regazo escolar. Revista Latinoamericana de Estudios Educativos. Distrito Federal, México,v. 23, n. 1, p. 151160, 2003.

FONTES, R. S. A escuta pedagógica à criança hospitalizada: discutindo o papel da educação no hospital. Revista Brasileira de Educação, v. 29, p. 119-138, 2005.

JIMÉNEZ, F. G.; GOMEZ, E. M.; HERNÁNDEZ, F. G. La pedagogía hospitalaria: reconsideración desde la actividad educativa. Revista Complutense de Educación, v. 13, n. 1, p. 303-365, 2002.

LIZASOÁIN RUMEU, O.; OCHOA LINACERO, B.; SOBRINO MORRÁS, A. Los pacientes pediátricos y la pedagogía hospitalaria en Europa. Acta Pediátrica Española, v. 57, n. 7, p. 364-372, 1999.

. Parámetros comunes em la pedagogia hospitalaria europea. CONGRÉS EUROPEU DE MESTRES I PEDAGOGS A L'HOSPITAL, 4., 2002. Barcelona. Actas... Barcelona: P.A.U. Education, 2002.

NASCIMENTO, E. M. R.; MOTA, E.; COSTA, M. C. N. Custos das internações de adolescentes em unidades da rede hospitalar integrada ao SUS em Salvador, Bahia. Epidemiologia e Serviços de Saúde, v. 12, n. 3, p.137-145, 2003.

OECD. PISA 2006: science competences for tomorow's world. Executive Summary. Paris, 2007.

OLIVEIRA, E. X. G.; TRAVASSOS, C.; CARVALHO, M. S. Acesso à internação hospitalar nos municípios brasileiros em 2000: territórios do Sistema Único de Saúde. Cad. Saúde Pública, v. 20, n. 2, p. S298-S309, 2004. 
ORGANIZACIÓN PANAMERICANA DE LA SALUD. Salud en las Americas. Washington, 2007.

SILVA, R. B. P.; RAMALHO, A. S.; CASSORLA, R. M. S. A anemia falciforme como problema de saúde pública no Brasil. Rev. Saúde Pública, v. 27, n. 1, p. 54-58, 1993.

UNESCO. Aulas hospitalarias: reflexiones de la VIII Jornada sobre Pedagogia

Hospitalaria. Santiago de Chile: Unesco; Fundación Carolina Labra Riquelme, 2006. 


\title{
A EDUCAÇÃO PROFISSIONAL: interfaces com a educação especial
}

\author{
Eliane de Sousa Nascimento
}

\section{INTRODUÇÃO}

A educação profissional é um processo de educação continuada que se prolonga durante toda a vida do trabalhador-cidadão e, no caso específico da educação de pessoas com deficiência, tem como objetivo favorecer a inclusão no mercado de trabalho, levando o sujeito à capacitação profissional e a compreensão das relações sociais no trabalho.

Sendo assim, o sistema educacional deve dispor dos meios necessários para responder às necessidades específicas dos alunos com deficiência, ou com necessidades educacionais especiais. Portanto, todos os que estão envolvidos com a aprendizagem desses educandos precisam refletir sobre o seu papel e, aperfeiçoar as condições oferecidas, para que esses alunos tenham um bom desempenho acadêmico com aprendizagens significativas e contextualizadas com suas necessidades e interesses.

$\mathrm{O}$ atendimento de estudantes com deficiência necessita de intervenções pedagógicas que usem metodologias e práticas de ensino adequadas às especificidades e peculiaridades de cada educando, além de possibilitar a promoção, a autonomia, a emancipação, a interação e a convivência entre os membros de um grupo bem como o desenvolvimento da emoção e afetividade. Esses procedimentos precisam estar de acordo com as necessidades de cada sujeito, respeitando o ritmo emocional e cognitivo de forma individualizada, quando possível. 
Portanto, o paradigma da inclusão envolve uma série de mudanças na instituição escolar para um ensino significativo e de qualidade, mas neste trabalho faremos algumas reflexões sobre a relação entre a educação profissional e a educação especial. Procuramos saber: quais as questões e os desafios na educação profissional de pessoas com deficiência.

Os objetivos que nortearam o estudo em questão foram: analisar a legislação brasileira e sua relação com a educação profissional, e refletir sobre a educação profissional interfaces com a educação especial. Como metodologia adotou-se a abordagem qualitativa, com pesquisa bibliográfica voltada para a área em questão visando à análise e reflexão das informações encontradas.

Este estudo se justifica pela necessidade de fazermos algumas reflexões sobre a educação profissional para educandos com deficiência, e também para contribuir e auxiliar com o processo de ensino-aprendizagem dessa população.

Segundo Carlos (2004, p. 83), existe no ordenamento jurídico diversas normas editadas com a intenção de conceituar a pessoa com deficiência. A Organização das Nações Unidas (ONU), que elaborou a Declaração Universal dos Direitos dos Deficientes, conceitua do seguinte modo,

\footnotetext{
O termo pessoas deficientes refere-se a qualquer pessoa incapaz de assegurar a si mesma total ou parcialmente, as necessidades de uma vida individual ou social normal, em decorrência de uma deficiência, congênita ou não, em suas capacidades físicas e mentais. (CARLOS, 2004, p. 83).
}

Usaremos as expressões portadoras de deficiência, e pessoas deficientes, quando constarem em documentos legais. Adotaremos neste estudo o termo, alunos com necessidades educacionais especiais, educandos e alunos com deficiência.

Atualmente, a formação para o trabalho exige cada vez mais níveis crescentes de escolaridade, que pode se desenvolver pela integração de dois tipos de aprendizagem: a formal (adquirida em instituições especializadas) e a não-formal (adquirida em diferentes ambientes, inclusive no próprio trabalho). De acordo com a legislação atual, a educação profissional pode acontecer através de parcerias entre os sistemas de ensino e a iniciativa privada.

A educação profissional também proporciona conhecimentos teóricos e operacionais relacionados à produção de bens e serviços, com um importante papel na aprendizagem inicial, continuada e da qualificação dos indivíduos, 
possibilitando o acesso a novos conhecimentos e saberes, que precisam estar articulados com as mudanças cada dia mais veloz do mundo do trabalho e da sociedade contemporânea.

\section{A LEGISLAÇÃO BRASILEIRA E SUA RELAÇÃO COM A EDUCAÇÃO PROFISSIONAL}

O Brasil aprovou a Lei de Diretrizes e Bases da Educação Nacional, n. 9.394, em 20 de Dezembro de 1996, conhecida como LDB ou Lei Darci Ribeiro. Ela estabelece dois níveis para a educação. A educação básica, que compreende: educação infantil para crianças de 0 a 6 anos, o ensino fundamental obrigatório, com oito anos e o ensino médio, de três anos; e a educação superior, que é constituída de cursos sequenciais, cursos de graduação e de pós-graduação; são estabelecidas, também, quatro modalidades educativas: educação de jovens e adultos, educação especial, educação indígena e uma modalidade complementar: a educação profissional (BRASIL, 1996).

De acordo com a atual LDB, a educação profissional deixa de ser parte diversificada do ensino médio, agora é a "etapa final da Educação Básica" (artigo 35), ou seja, após o ensino médio, ou concomitante com o mesmo (no $3^{\circ}$ ano), mas sem substituí-lo, nem tomar o lugar dessa formação geral do educando é que poderá haver "a preparação para o Exercício de Profissões Técnicas" (artigo 36). É definida, portanto como complementar a educação básica podendo ser desenvolvida em diferentes níveis para jovens e adultos com escolaridade diversa (BRASIL, 1996).

A educação básica na atualidade deve desenvolver no educando o exercício da cidadania e meios para progredir no trabalho e em estudos posteriores (artigo 22). As competências básicas, garantidas pela educação básica são imprescindíveis à formação profissional, e caso o aluno não possua, deve recuperálas em etapas ou módulos de nivelamento (BRASIL, 1996).

Explica Berger Filho (1999), que a nova Lei se constitui um marco para a educação profissional, pois as leis de diretrizes e bases anteriores, ou as leis orgânicas para os níveis e modalidades de ensino, sempre trataram da educação profissional apenas superficialmente.

O Decreto n. 2.208/97, que regulamenta o $\$ 2^{\circ}$ do art. 36 e os artigos 39 a 42 da Lei 9.394/1996, que estabelece as diretrizes e bases da educação nacional, no artigo $4^{\circ}$ define três níveis de organização dos cursos de educação profissional: Nível Básico: destinado à qualificação e reprofissionalização de traba- 
lhadores independentes de escolaridade prévia; Nível Técnico: destinado a proporcionar habilitação profissional a alunos matriculados ou egressos do ensino médio, devendo ser ministrado em forma estabelecida por este decreto; Nível Tecnológico: correspondente a cursos de nível superior na área tecnológica, destinados a egressos do ensino médio e técnico. (BRASIL, 1997).

Na opinião de Cordão (2002, p. 13), "as novas Diretrizes Curriculares para a Educação Profissional de Nível Técnico estão centradas no conceito de competências por área profissional." São exigidos dos trabalhadores: maior capacidade de raciocínio, autonomia intelectual, pensamento crítico, iniciativa própria, espírito empreendedor e capacidade de visualização e resolução de problemas, e desenvolvimento de competências. Na Lei n. 9.394, no artigo 39, inclusive, é estabelecido que, o trabalhador deve ser conduzido "ao permanente desenvolvimento de aptidões para a vida produtiva.” (BRASIL, 1996).

Observamos que, a antiga formação profissional baseava-se apenas na preparação para a execução de um determinado conjunto de tarefas, na maior parte das vezes, de maneira rotineira e burocrática (Fordismo). ${ }^{1} \mathrm{O}$ novo paradigma para a educação profissional é conduzir o cidadão: "ao permanente desenvolvimento de aptidões para a vida produtiva" intimamente "integrada às diferentes formas de educação ao trabalho, à ciência e à tecnologia” (artigo 39). De acordo com Cordão (2002, p.13),

A nova educação profissional requer, para além do domínio operacional de um determinado fazer, a compreensão global do processo produtivo, com a apreensão do saber tecnológico que informa a prática profissional e a valorização da cultura do trabalho, pela mobilização dos valores necessários à tomada de decisões.

Não basta aprender a fazer, é preciso saber que existem outras maneiras para aquele fazer e saber (Toyotismo ${ }^{2}$ ) e deter a inteligência do trabalho, de-

\footnotetext{
${ }^{1}$ Modelo padrão do capitalismo desenvolvido ao longo do século XIX, e que se institucionalizou no mundo industrial até os anos 1970. Tinha como característica a produção em massa mais ou menos homogêneas, controle rígido dos tempos e dos movimentos, fragmentação das funções (um homem para uma máquina), que eram exercidas por um grande números de trabalhadores, fazendo a separação entre a elaboração e a execução das tarefas (ANTUNES, 2001).

${ }^{2}$ Forma particular de expansão do capitalismo monopolista do Japão do Pós-Guerra, respondendo à necessidade de uma produção orientada para pequenas procuras e para produtos diferenciados, com um homem para várias máquinas, garantindo-se o aumento de uma produção sem maiores encargos, com mão-de-obra e produção somente do necessário e no tempo adequado. Os trabalhadores devem ser qualificados, e "o operário deve pensar e fazer pelo e para o capital" (ANTUNES, 2001, p. 23).
} 
sempenhar com competência e habilidade suas funções e atribuições ocupacionais.

Entre os autores contemporâneos, que tentam fazer a apreensão e o debate da educação profissional, temos Souza (1999) que afirma que a educação profissional de nível técnico habilita as correspondentes qualificações e especializações, através de etapas ou módulo inicial, destinado à equalização de conteúdos básicos indispensáveis ao desenvolvimento das competências profissionais aos cursos e módulos complementares de especialização, ao aperfeiçoamento e atualização de pessoal já qualificado ou habilitado e a complementação da própria qualificação.

O mesmo autor explica que, houve a separação entre o ensino médio e o ensino profissional denominado na nova LDB por educação profissional, e as Escolas Técnicas, Centros Federais de Educação Tecnológica (Cefets), atualmente oferecerem conteúdos profissionais pela via do sistema modular, de modo desvinculado dos conteúdos gerais. O Serviço Nacional de Aprendizagem Industrial (Senai), bem como o Serviço Nacional de Aprendizagem Comercial (Senac), com a autoformação tecnológica, e "o Sistema S", agora oferecem treinamento fragmentado, demarcado pelas necessidades mais estreitas do capital. Em outros termos, transpõe-se a experiência das agências de preparação de mão de obra para o mercado de trabalho.

Manfredi (2003) pondera que a escola, com o crescimento do capitalismo industrial passou a ser agente social da preparação para a inserção no mundo do trabalho, mas o que é ensinado se processa de modo distante do que acontece no mundo do trabalho. Existe o déficit de políticas públicas que atendam às novas configurações do mundo do trabalho, para a inserção de trabalhadores desempregados, e programas integrados de escolarização e profissionalização para jovens e adultos analfabetos ou com escolaridade parcial.

Viégas e Carneiro (2003) apontaram que, a reforma da educação profissional procura responder a empregabilidade, apreender a capacidade de desempenho no trabalho com eficiência, eficácia e efetividade, a preparação para um posto de trabalho e a sua preservação.

Muitas foram as mudanças ocorridas com relação a educação profissional no Brasil ao longo dos anos. Entendemos, portanto, que o novo modelo de educação profissional adotado pelo Ministério da Educação, complementar à formação geral, procurou criar cursos integrados ao ensino médio.

Mas, constatamos através das evidências postuladas pelos muitos autores consultados que, na prática a educação profissional desejada e a realizada estão 
longe de ser a ideal. No que se refere ao atendimento da proposta de inclusão de pessoas com deficiência nas relações sociais de trabalho, é preciso a definição e o desenvolvimento de um programa de qualificação profissional que atenda essa demanda de indivíduos, e também, o assessoramento às empresas para o cumprimento da legislação brasileira, com respeito à contratação profissional. A educação profissional voltada para educandos com deficiência necessita de uma práxis pedagógica que atenda as necessidades desses alunos, é o que veremos a seguir.

\section{A EDUCAÇÃO PROFISSIONAL E A EDUCAÇÃO ESPECIAL: A PRÁXIS PEDAGÓGICA}

Entendemos que a relação educação profissional/educação especial passa pela assimilação da educação inclusiva, pois a escola é o primeiro passo para a inserção no mundo do trabalho. Mas, para que as instituições dedicadas a educação profissional acolham alunos com deficiência é necessário que, a sua programação de cursos desenvolva currículos e metodologias que respeitem as especificidades, dificuldades, limites, possibilidades e o ritmo de aprendizado de cada educando.

Chamamos atenção que, a organização de cursos de educação profissional necessita atender à diversidade das pessoas com deficiência, visando desenvolver as competências e as habilidades individuais dos educandos. Devem também, assegurar a evolução cognitiva com conhecimentos contextualizados e focados na construção da identidade dos alunos.

Para Viegas e Carneiro (2003, p. 21), “[...] a legislação da Educação Profissional está voltada para oferecer respostas concretas de como se deve operacionalizar a relação educação e trabalho produtivo através do processo escolar [...]." Portanto, a escola deve propiciar aos alunos com deficiência, o desenvolvimento de competências essenciais ao seu projeto de vida, e dar condições para o enfrentamento da grande competitividade e exigência do mundo do trabalho e autonomia para viver sua vida, realizando atividades laborais e trabalhos compatíveis com as suas singularidades.

Um ensino com qualidade envolve oferta de atividades e proposições didáticas significativas, contextualizadas, que correspondam às necessidades dos alunos, como também a um processo de reelaboração e de reestruturação das instituições escolares em geral, proporcionando o acesso de todos os educandos a oportunidades e possibilidades educacionais e sociais (FORTES, 2005). 
Pensando nisso, é imprescindível uma relação dialógica entre educador e educandos para o desenvolvimento cognitivo, a autonomia, a emancipação e a independência dos educandos. Segundo Freire (2003), a práxis é a integração entre pensamento e ação, é preciso saber dosar a relação teoria/prática, pois quando se desenvolve intervenções pedagógicas com objetivo do aluno produzir ou construir conhecimentos, não se ensina conhecimentos e conteúdos sem a participação e reflexão dos educandos.

Freire (2003) ainda chama a atenção para o fato de que o ensino precisa proporcionar condições e possibilitar que os educados, nas suas relações uns com os outros, ou com o professor, possam assumir-se como uma pessoa social e histórica, que reflete, tem sonhos, ou seja, tem uma vida. Ensinar exige desenvolver o senso crítico no aluno, pois, a práxis é reflexão e a atuação dos homens sobre o mundo para mudá-lo.

Conforme Antunes (2002, p. 28), a aprendizagem depende do desenvolvimento prévio e anterior, também do desenvolvimento proximal do aluno, sendo que esta não é uma propriedade estável e estática, supondo que cabe ao professor oferecer ajuda ao aluno para que ele crie diferentes e frequentes Zonas de Desenvolvimento Proximal (ZDP), permitindo dessa forma que progressivamente o aluno desenvolva tarefas mais complexas. O trabalho do professor é essencial para a interação aluno/aluno e aluno/professor, para um avanço progressivo e significativo. A ZDP segundo Vigotski (1998, p. 112),

\footnotetext{
[...] é a distância entre o nível de desenvolvimento real, que se costuma determinar através da solução independente de problema, e o nível de desenvolvimento potencial, determinado através da solução de problemas sob a orientação de um adulto ou em colaboração com um companheiro mais capaz.
}

Portanto, o professor que se envolve e participa da caminhada, do aprendizado com seus alunos, entende melhor as dificuldades e possibilidades de maneira individualizada, e assim, consegue provocar a construção do conhecimento com maior adequação. $\mathrm{O}$ docente precisa estar atento à singularidade de cada educando que participa da turma, buscando o diálogo entre todos os que estão envolvidos no processo (MANTOAN, 2003).

Outra contribuição para a práxis é dada por Freire (2003), quando ele nos mostra que a importância da construção de um saber junto ao educando está amarrado a relevância que o professor dá ao contexto social e cultural do aluno, a comunidade na qual trabalha. Os conteúdos são trabalhados a partir da reali- 
dade vivida por esses, um diálogo constante durante todo o processo de ensinoaprendizagem.

Antunes (2002), afirma que toda escola é um centro epistemológico por excelência, pois é um lugar onde se constrói saberes, solidificam-se os conhecimentos já existentes, aprimoram-se capacidades, são descobertas e aperfeiçoadas competências e estimulam-se inteligências. Sendo assim, a educação deve promover o desenvolvimento dos alunos, "[...] na medida que desperta a atividade mental construtiva, capaz de transformá-los em pessoas únicas, singularíssimas, inseridas no contexto de um grupo social determinado" (ANTUNES, 2002, p. 18).

Conforme Viégas e Carneiro (2003), a educação inclusiva exige trabalhar com programas flexíveis e permeáveis às mudanças e a pluralidade dos indivíduos, detentores de singularidades cerebrais, mentais, psicológicas, afetivas, intelectuais, subjetivas e culturais.

O aluno "especial" deve poder evoluir em sua individualidade e não apenas no avanço do programa. Isto implica em desenvolver competências e habilidades individuais que lhe assegurem autonomia de movimentos e meios de se afirmar socialmente. Ou seja, se afirmar pelo trabalho. (VIÉGAS; CARNEIRO 2003, p. 27).

Os currículos dos cursos de educação profissional precisam ter conteúdos formativos atrelados com o mundo do trabalho e dar ênfase na aquisição e no exercício de competências. O planejamento deve ser flexível para que possa ser reformulado, revisto, pois a formação do aluno é muito importante.

Portanto, refletir sobre o valor e significado da ação docente é refletir sobre o professor e a condição, em que se encontra envolvido, a fim de que possamos realmente realizar uma práxis pedagógica transformadora, que envolva uma educação que não separa homem e mundo, mas em uma contínua interação. Afirma Sander (1984, p. 13) que, a práxis se refere ao conjunto de atos e práticas humanas com objetivo de criar condições indispensáveis a produção e a reconstrução social.

Os alunos com deficiência precisam ter acesso a cursos de educação profissional diferenciados, em termos de infraestrutura material (física e de equipamentos); em termos de competência e de qualificação dos professores; e o desenvolvimento nos alunos de sua interação, afeto e emoção (competências 
interacionistas); A aprendizagem deve ter um tempo de duração de acordo com as habilidades e potencialidades a serem desenvolvidas, no ritmo emocional e cognitivo de cada educando.

Constatamos que as pessoas com deficiência que procuram a educação profissional, em cursos de nível técnico, para obtenção de qualificação profissional, não possuem, em sua maioria, o nível médio, sendo assim, as Escolas e Cefets ainda têm uma pequena quantidade de alunos com deficiência (VIÉGAS; CARNEIRO, 2003). De acordo com os dados do Censo Escolar do MEC, no ano 2000, havia apenas 280 mil pessoas com deficiência cursando as escolas regulares do ensino fundamental no Brasil, e apenas três mil no ensino médio (PASTORE, 2000).

Essa realidade evidencia a dificuldade dessa população no acesso a cursos que possam lhe dar uma qualificação profissional que atenda às exigências do mercado de trabalho e, o porquê das ocupações desempenhadas por essa população serem as que exigem pouca escolaridade e qualificação, com atividades vinculadas a tarefas sem relevância social e intelectual, sem vínculo com as áreas do conhecimento científico.

É necessário possibilitar condições básicas para que essa população tenha uma adequada formação e capacitação e, com capacidade de tornarem-se membros produtivos e independentes, com habilidades e competências cognitivas, emocionais e de interação, que possibilitem o acesso e a permanência no mercado de trabalho.

Ressaltamos que os estabelecimentos da Rede Federal de Educação Tecnológica, para ter uma educação inclusiva deverão adequar-se às necessidades das pessoas com deficiência. A educação profissional desses alunos constituem um verdadeiro desafio. Na rede regular de ensino percebemos alguns êxitos, mas a formação profissional dos alunos com deficiência continua segundo Viégas e Carneiro (2003, p. 41), "distante da agenda prioritária de organização do ensino nas diferentes esferas administrativas, e, sobretudo, na esfera dos sistemas públicos." Afirma também que, é enorme a resistência das instituições para iniciativas voltadas para a inserção de alunos com deficiência em seus cursos e programas de educação profissional. O déficit de atendimento a essa demanda de alunos ainda é muito grande.

Ainda na opinião de Viégas e Carneiro (2003, p. 81), as instituições de ensino para o encaminhamento ao mercado de trabalho de alunos da educação profissional com deficiência e sem deficiência precisam de algumas estratégias: 
"um trabalho de sensibilização com as empresas; um serviço de supervisão para o necessário acompanhamento do aluno; e um setor para firmar e organizar cursos com as Escolas da Rede Federal Tecnológica e/ou com o Sistema." Algumas ações são imprescindíveis:

Realizar visitas às empresas, para captação de vagas; realizar análise de tarefas; preparar programas de cursos; definir perfil dos alunos; formar banco de instrutores; divulgar cursos através da mídia; realizar cursos, desenvolvendo as habilidades básicas, específicas e de gestão concomitantemente; sendo que as habilidades específicas deverão ser realizadas como estágio nas empresas já contratadas. Os cursos deverão estar norteados pela metodologia de jovens e adultos e deverão utilizar a informática como ferramenta de aprendizagem; formar banco de dados dos alunos já qualificados; encaminhar para o mundo do trabalho e acompanhar até que a pessoa adquira independência e autonomia; e, providenciar a contratação do aluno, pela empresa. (VIÉGAS: CARNEIRO, 2003, p. 81-82).

Miranda (2006) afirma que, a educação profissional no Brasil para as pessoas com deficiência vem sendo oferecida na maioria das vezes por organizações especializadas da sociedade civil, devido à exclusão dessas pessoas de programas desenvolvidos pelas organizações públicas e/ou privadas, criadas para desenvolver programas que não são oferecidos pelo estado ou pelo mercado. Ressalta ainda que, essas organizações especializadas foram criadas para substituir o Estado, a própria sociedade, com o objetivo de proteger e segregar as pessoas com deficiência, uma sociedade que deseja distância da convivência com esse grupo de pessoas, ou seja, não tem a intenção de defender os direitos das pessoas com deficiência. Nesse contexto, foram criados os programas de educação profissional, contendo características das políticas sociais brasileiras (o assistencialismo e o protecionismo) e característica do modelo de atendimento às pessoas com deficiência.

Entre os muitos autores que nos possibilitam conhecimentos para uma reflexão sobre a prática educativa, a promoção, a emancipação, a autonomia e a independência do ser dos educandos, destacamos nesse trabalho o educador Paulo Freire (2003). Em seu último livro, intitulado Pedagogia da autonomia: saberes necessários à prática educativa, o autor analisa saberes fundamentais para a práxis pedagógica. Ele diz que ensinar exige: segurança, competência profissio- 
nal e generosidade; comprometimento; compreender que a educação é uma forma de intervenção no mundo; liberdade e autoridade; tomada consciente de decisões; ser imprescindível saber escutar; reconhecer que a educação é ideológica; ter disponibilidade para o diálogo; e querer bem aos alunos. Também, nos chama a atenção da importância de nunca nos acomodar, e da esperança e otimismo necessários para mudanças, pois "somos seres condicionados, mas não determinados.” (FREIRE, 2003, p. 17).

\section{CONSIDERAÇÕES FINAIS}

Ao analisarmos como vêm acontecendo à práxis pedagógica no contexto da educação profissional interfaces com a educação especial, constatamos que a investigação desta temática requer uma continuidade de estudos, pois conseguimos o entendimento apenas em relação a alguns aspectos. Nossa intenção com este trabalho foi contribuir com algumas reflexões em torno do tema, com o intuito de oferecer informações, subsídios e esclarecimentos para o aprimoramento e mudanças na práxis pedagógica do professor, para um ensino-aprendizagem mais significativo dirigido a educandos com deficiência.

Através dos autores consultados constatamos que, a nova política de educação profissional prioriza a educação continuada e estimula a articulação entre escolas, trabalhadores e empresários, de modo que os setores educacionais e produtivos atuem de forma integrada. Percebemos também que, a educação profissional ao longo dos anos passou por inúmeras transformações, mas ela não tem acompanhado o acelerado desenvolvimento tecnológico das últimas décadas, as grandes mudanças na configuração das profissões e do mercado de trabalho, existindo inclusive uma carência no atendimento de alunos com deficiência nessa modalidade da educação brasileira.

Com esse estudo ficou evidente que na educação profissional de educandos com deficiência é necessário fazer mudanças na práxis pedagógica, principalmente por ser o educador aquele que exerce o papel de um dos mediadores entre o total da sociedade e o particular do educando. Para uma educação significativa e com qualidade, o professor precisa desenvolver algumas qualidades: apreensão da realidade em que trabalha e competência no campo teórico de conhecimento na qual atua. $\mathrm{O}$ afastamento de seu trabalho ocorre quando o professor ignora a realidade em seu entorno, e restringe seu trabalho a uma rotina de sala de aula, reduzindo-se a mera transmissão de informações, atitude que não combina com sua função de educador. 


\section{REFERÊNCIAS}

ANTUNES, Ricardo Antunes. As Metamorfoses no mundo do Trabalho. In: GOMES, Álvaro (Org.). O trabalho no século XXI: considerações para o futuro do trabalho. São Paulo: Anita Garibaldi; Sindicato dos Bancários da Bahia, 2001, p. 17-31.

ANTUNES, Celso. Vygotsky, quem diria?! Em minha sala de aula. Petrópolis: Vozes, 2002 .

BERGER FILHO, Ruy Leite. Educação profissional no Brasil: novos rumos. Revista Iberoamericana de Educação, n. 20, maio/ago. 1999. Disponível em: http: <//www.rieoei.org/ rie20a03.htm >. Acesso em: 20 maio 2006.

BRASIL. Lei n. 9.394, de 20 de dezembro de 1996. Estabelece as diretrizes e bases da educação nacional. CURY, Carlos Roberto Jamil. Legislação educacional brasileira. 6. ed. Rio de Janeiro: DP\&A, 2003.

Decreto n. 2.208, de 17 de abril de 1997. Regulamenta o $\$ 2^{\circ}$ do art. 36 e os artigos 39 a 42 da Lei 9.394/1996, que estabelece as diretrizes e bases da educação nacional. Brasília: Senado Federal. Disponível em: http://portal.mec.gov.br/seesp/arquivos/pdf/ dec2208.pdf.. Acesso em: junho de 2006.

CARLOS, Vera Lúcia. Discriminação nas relações de trabalho. São Paulo: Macedo, 2004.

CORDÃO, Francisco Aparecido. Perspectivas para a educação profissional: novo paradigma curricular por competência. ABC Educativo. Revista da Educação, São Paulo, v. 3, n. 14, 2002, p. 12-14.

FORTES, Vanessa Gosson Gadelha de Freitas. A inclusão da pessoa com deficiência visual na UFRN: a percepção dos acadêmicos. 2005. 237 f. Dissertação (Mestrado em Educação) - Universidade Federal do Rio Grande do Norte, Natal. 2005.

FREIRE, Paulo. Pedagogia da autonomia: saberes necessários à prática educativa. São Paulo: Paz e Terra, 2003.

MANFREDI, Maria Silvia. Educação profissional no Brasil. São Paulo: Cortez, 2002.

MANTOAN, Teresa Egler Mantoan. Inclusão escolar. O que é? Por quê? Como fazer? São Paulo: Moderna, 2003.

MIRANDA, Theresinha Guimarães. Educação profissional de pessoas portadoras de necessidades especiais. Caderno CRH, Salvador, v. 14, n. 34, p. 99-123, jan./jun. 2001.

. Trabalho e deficiência: velhos desafios e novos caminhos. In: MANZINI, Eduardo José. Inclusão e acessibilidade. Marília: ABPEE, 2006. p. 159-170.

PASTORE, José. Oportunidades de trabalho para portadores de deficiência. 2. ed. São Paulo: Ltr, 2000.

SANDER, Benno. Consenso e conflito: perspectivas analíticas na pedagogia e na administração da educação. São Paulo: Pioneira; Rio de Janeiro: EDUFF, 1984.

SOUZA, Donaldo Bello de. Reestruturação produtiva trabalho da educação no Brasil. In. SOUZA, Donaldo Bello de; SANTANA, Marco Aurelio; DELUIZ, Neise (Orgs). Trabalho 
e educação: centrais sindicais e reestruturação produtiva no Brasil. Rio de Janeiro: Quartel, 1999, p. 43-84.

VIÉGAS, Conceição de Maria Corrêa; CARNEIRO, Moaci Alves. Educação profissional: indicações para a ação: a interface educação profissional/educação especial. Brasília: MEC/ SEESP, 2003.

VIGOTSKI, Lev Semenovich. A formação social da mente: o desenvolvimento dos processos psicológicos superiores. São Paulo: Martins Fontes, 1998. 



\section{SÍNDROME DE DOWN: desafios e perspectivas na inclusão escolar}

Antonilma Santos Almeida Castro

Susana Couto Pimentel

\section{DA CARACTERIZAÇÃO DA SÍNDROME DE DOWN ÀS POSSIBILIDADES DE DESENVOLVIMENTO}

Pensar as possibilidades de desenvolvimento das pessoas com Síndrome de Down é efetivar o exercício pela construção de um mundo mais justo, e, uma sociedade melhor, mais justa só se constrói sem o ranço do preconceito, com a busca contínua de informação e conhecimentos que possam amenizar os processos de exclusão que se instalam em diferentes contextos sociais.

Nessa busca de conhecimentos, ressalta-se também a necessidade de se fortalecer informações sobre as especificidades dos sujeitos que têm necessidades educacionais especiais, pois conhecer as singularidades possibilita o afastamento dos preconceitos, a concretização de posturas e de ações centradas na intervenção, consequentemente, no estímulo e na crença de desenvolvimento. É oportuno destacar ainda que o conhecimento do diagnóstico não pode alterar o compromisso dos professores com a formação e com o investimento educacional para melhorar a qualidade de vida. Segundo Alves (2007, p. 41)

[...] na criança com Síndrome de Down a prontidão para a aprendizagem depende da complexa integração dos processos neurológicos e da harmoniosa evolução de funções específicas, como a linguagem, percepção, esquema corporal, orientação espaço-temporal e lateralidade. 
Comungamos com a autora e temos a consciência de que é preciso haver investimentos externos para que a criança com Síndrome de Down possa amadurecer as funções neurológicas, executar atividades diárias e, consequentemente, aprender e se desenvolver. Vale ressaltar que não se quer aqui esquecer que existem alterações no processo de internalização de conceitos que dificultarão a construção dos conhecimentos e, sobretudo, na aquisição da linguagem. Porém, para amenizar as dificuldades é preciso que, no contexto escolar, o professor conheça e estimule capacidades de desenvolvimento desses sujeitos.

A conscientização dos educadores acerca da potencialidade dessa criança é de extrema importância, pois possibilita o incremento no processo educacional e no investimento em ações metodológicas que promovam a criatividade e momentos que melhorem a qualidade de vida.

Uma das formas se investir nas possibilidades de desenvolvimento da criança com Síndrome de Down é a compreensão de que a síndrome não se constitui em uma doença, que pode ser prevenida, que se tem cura ou tratamento para se diminuir o grau do comprometimento na base cognitiva. Existem sim processos de intervenção que podem estimular as potencialidades de modo que o cérebro possa, dentro da sua plasticidade, responder aos estímulos e as exigências externas que são feitas aos indivíduos.

A Síndrome de Down é um acidente genético que ocorre no par do cromossomo 21, com a presença de um cromossomo extra. Por isso, essa síndrome é também chamada de trissomia 21. A presença extra desse cromossomo acarreta no desenvolvimento intelectual um retardo leve ou moderado, em virtude de alterações cerebrais. É oportuno destacar que esse atraso no desenvolvimento cognitivo não implica necessariamente em uma má qualidade de vida, ao contrário, é possível sim, se possibilitar uma vida com qualidade para essas pessoas.

As crianças com Síndrome de Down apesar de possuírem alterações fenotípicas semelhantes como: aparência arredondada da cabeça, pálpebras estreitas e levemente oblíquas, boca pequena podendo-se projetar um pouco a língua, única prega palmar, pescoço curto, mãos e pés pequenos e grossos etc.; diferem entre si em aspectos gerais do desenvolvimento como: linguagem, motricidade, socialização e habilidades da vida diária. Porém, comumente apresentam crescimento físico mais lento; maior tendência a aumento de peso; atraso no desenvolvimento motor devido à hipotonia nos primeiros meses de vida, ou seja, menor tonicidade nos músculos e atraso no desenvolvimento mental. 
Outro fator a se destacar é que a síndrome não é progressiva, nem contagiosa. A própria flacidez, gerada pela hipotonia muscular pode ser reduzida com o tempo por meio de exercícios fonoaudiológicos e fisioterápicos, nos quais se investe no amadurecimento do Sistema de Nervoso Central (SNC) o que contribui, de forma significativa, para o desenvolvimento de aprendizagens.

Assim quando se pensa em possibilidades de desenvolvimento da criança com a síndrome não se limita ao conhecimento dos conceitos abstratos nas diversas disciplinas escolares, mas, sobretudo em ações que vislumbrem a autonomia do sujeito.

É importante que a escola tenha no seu planejamento diário atividades que exijam do sujeito com a síndrome trabalhos de: cooperação, organização, constituição, movimentos, compreensão, exploração de propostas lúdicas e materiais diversos para que a criança possa realizar atividades motoras como: correr, pular, rolar, entre outras. Essas ações contribuirão para o desenvolvimento social, afetivo, motor e da linguagem. Quanto maior for a sua estimulação, mais internalizados serão os domínios. Nesta direção Alves (2007, p. 39) diz que "cabe, portanto ao professor ser investigador, ou seja, aquele que ouve, vê e procura compreender o potencial de cada criança com quem trabalha."

Alves (2007) ainda ressalta que não se pode limitar a possibilidade de desenvolvimento intelectual dos sujeitos. A educação da criança com a síndrome deve atender às suas necessidades especiais, sem se desviar dos princípios básicos da educação proposta às demais pessoas. Assim, as atividades desenvolvidas no contexto escolar não podem se limitar ao espaço da sala de aula, mas extrapolar os muros da escola possibilitando o contato com diversos lugares para conhecer o movimento das pessoas, dos animais e de tudo que está em sua volta. É preciso possibilitar um contato amplo com o meio, para que a criança possa visualizar o mundo por um ângulo bem maior.

A exploração de atividades que requeiram um maior contato com a relação espaço/tempo reforça a inteligência, amplia o conhecimento do espaço por onde se movimenta e aguça a curiosidade em relação ao tempo em que as ações ocorrem, aumentando o seu desenvolvimento na base cognitiva.

É válido salientar que a inteligência da criança com Síndrome de Down evolui de acordo com as especificidades dos sujeitos, não existindo assim tempo fixo para o desenvolvimento da aprendizagem. Outro aspecto a se observar é o prolongamento do tempo para o desenvolvimento das atividades, pois a concentração desaparece com facilidade. Algumas crianças aprendem a ler e a escrever com certa rapidez, outras precisam de um tempo mais longo. Assim, faz- 
se necessário planejar atividades que estejam adequadas ao tempo de realização desses sujeitos. É preciso ter atenção com as atividades mais prolongadas, não se deve cobrar das crianças com a síndrome um tempo de atenção mais prolongado (ALVES, 2007).

Para que haja o desenvolvimento da linguagem tanto impressiva quanto expressiva, é preciso que a criança com a síndrome tenha um contato diário e permanente com diversas situações sociocomunicativas, que não devem se restringir apenas espaço da sala de aula ou dos membros da família. É necessário que a criança esteja em contato permanente com pessoas pertencentes a grupos sociais diferentes, para que possa enriquecer o acervo vocabular, o uso lexical, instalação e a articulação dos sons, a produção de texto orais e escritos (CASTRO, 2002).

Segundo Vygotsky (1998) a interação com diferentes contextos comunicativos possibilita a aquisição da linguagem oral e se repercute na produção da linguagem escrita. A troca interativa com pessoas mais experientes é de suma importância, pois permite que a criança observe como as palavras são articuladas, como é feita a classificação das coisas, pessoas, objetos e animais e isso contribui para o seu entendimento do que ouve ou vê. Isso gera aos poucos um amadurecimento no raciocínio, melhorando a persistência nas ações cognitivas e motoras, tanto relativas à fala, quanto à escrita.

É pertinente lembrar que o desenvolvimento da fala é também formação da inteligência. Nas crianças com a síndrome a aquisição e a evolução da linguagem se processam lentamente. Por isso a necessidade dos estímulos externos, tendo em vista que elas apresentam atraso na produção e articulação dos sons que dependem dos movimentos da língua, dos lábios, dos dentes, dos maxilares. Esse atraso na produção e articulação pode dificultar o ritmo e fluência da produção dos textos orais. Diante disso, quanto maior for o contato com as pautas interativas orais, maiores serão as possibilidades de desenvolvimento, pois o cérebro possui capacidades de aprendizagem, que estão atreladas à internalização de estímulos que se dão por meio da aprendizagem, intimamente ligada aos fatores biológicos, ambientais e sociais.

Nesta direção ressalta-se a importância e a necessidade de um acompanhamento multidisciplinar para a criança com Síndrome de Down, o que poderá possibilitar o seu desenvolvimento na esfera educacional, tendo em vista que a aprendizagem escolar não se processa de forma isolada no interior dos muros da escola, mas em intensa interação como o meio social. 


\section{ESCOLARIZAÇÃO DA PESSOA COM SÍNDROME DE DOWN: DA SEGREGAÇÃO À INCLUSÃO ESCOLAR}

Embora hoje se tenha clareza das possibilidades de desenvolvimento da pessoa com Síndrome de Down, a compreensão do seu processo de aprendizagem nem sempre foi essa. As primeiras iniciativas de escolarização das pessoas com Síndrome de Down têm enfoque no modelo médico, que analisava a deficiência sob o prisma das limitações orgânicas. Assim, numa perspectiva educacional o processo de atendimento às pessoas com deficiência intelectual esteve, ao longo da história, direcionado por três paradigmas: o segregacionista, o da integração e, mais recente, o da inclusão.

O paradigma segregacionista preconizava um sistema educacional divido em dois subsistemas: regular e especial. "[...] nos anos de 1950 e 1960, a resposta institucional às necessidades educacionais das crianças com deficiência mental foram às classes especiais ou centros educacionais específicos." (VOIVODIC, 2004, p. 58). Isto potencializava a segregação e a rotulação, tendo em vista que alunos com "baixa" capacidade intelectual eram encaminhados para a educação especial, institucionalizada, com base no pseudo ideal de homogeneização.

Outro paradigma educacional foi o da integração escolar cuja ideologia é de que a escola trabalha da forma correta e que, portanto, os alunos precisam submeter-se a ela. "Em suma, a escola não muda como um todo, mas os alunos têm de mudar para se adaptarem às suas exigências." (MANTOAN, 2003, p. 23).

Esse paradigma da integração, predominante até início da década de 90 do século XX, garantiu o acesso às diferenças na escola regular, "consentindo" na abertura do espaço escolar para os "diferentes", embora reproduzisse a segregação com a criação das chamadas "classes especiais" na escola regular. A proposta da integração fundamentava-se na concepção de que os "diferentes" deveriam se adequar às condições oferecidas pela escola devendo buscar condições para garantir sua permanência e sucesso no ensino escolar.

Hoje, com os avanços das pesquisas das neurociências, a tendência é de se considerar a plasticidade cerebral como possibilidade de desenvolvimento das potencialidades da pessoa com deficiência intelectual. Esse novo enfoque trouxe consigo a defesa da inclusão e, consequentemente a proposta de repensar e reestruturar o sistema escolar, de forma que atenda às necessidades de todos os alunos. 
As diversas práticas de inclusão da pessoa com Síndrome de Down têm demonstrado que elas: 1 . estimulam o desenvolvimento de habilidades na convivência com as diferenças; 2 . oportunizam interação entre alunos - aprendizagem colaborativa; 3 . favorecem aspectos do desenvolvimento geral e aprimoramento da linguagem; 4. devem ser pautada no atendimento às necessidades educacionais específicas, sem abandonar os princípios básicos da educação propostos aos demais alunos; 5 . prevêem um trabalho voltado para potencialidades; 6. requerem, em algumas situações, um processo de adaptação curricular.

Diante disso, para que a inclusão se efetive entende-se que é necessária a elaboração de políticas públicas educacionais que prevejam a formação continuada dos professores do ensino regular, de modo que os permita conhecer as potencialidades e necessidades seus alunos e os possibilite ressignificar suas intervenções, maximizando seus efeitos. Além disso, as políticas públicas devem prever a efetiva operacionalização de um suporte pedagógico ao trabalho de inclusão desenvolvido pela escola regular.

\section{O CURRÍCULO PARA ATENDER A PESSOAS COM SÍNDROME DE DOWN NA ESCOLA REGULAR}

Como visto anteriormente, o paradigma da inclusão defende que a escola precisa atender às necessidades educativas dos educandos que nela se inserem. Isto significa deixar de ignorar os itinerários individuais, ou melhor, passar a ouvir e ver aqueles a quem não se falava, ouvia e via. Passar a ouvi-los e vê-los significa estar disposto a buscar pistas e indícios que apontem para a melhor forma de ajudá-los a aprender.

Ver e atender o outro considerando as suas diferenças significa inseri-lo em relações interpessoais, para que ele avance em seus processos de desenvolvimento e aprendizagem. "Quando se inicia a aprendizagem da leitura, escrita e cálculo, essas crianças precisam de um ensino mais individualizado e bem mais lento." (MILANI, 2005, p. 56).

Nessa perspectiva, o currículo da escola regular precisa ser (re)pensado em relação às pessoas com Síndrome de Down. A identidade e alteridade dessas pessoas precisam ser referendadas pela coletividade, de forma a garantir a necessária produção individual de sentido, de modo que potencialize o aprender. Para isso, é necessário valorizar as referências individuais, prestar atenção às singularidades e estabelecer, a partir daí, alterações curriculares que favoreçam aprendizagens. Por exemplo, como visto anteriormente 
as conexões cerebrais das crianças portadoras da Síndrome de Down são mais lentas e fracas e por isso requerem mais repetições. A integração entre a ordem verbal e a resposta é difícil, porque a criança precisa fazer uma síntese entre a fala, a instrução e a ação. (MILANI, 2005, p. 50).

Um modo de se considerar essas singularidades é repensando o tempo cronológico estabelecido pelo currículo escolar para que se processe a aprendizagem: unidades ou bimestres, semestres e anos letivos. Será que o aprendizado está limitado a esta esfera cronológica do tempo ou será que as singularidades conferem a cada aprendente um tempo diferente de aprender, um tempo que pode requerer longos períodos ou ciclos? (PIMENTEL, 2007).

Diante da complexidade do tempo de aprender, Bérgson refere-se ao tempo como uma mudança que envolve alterações qualitativas, o 'ir-se tornando' (CHAMPLIN; BENTES, 1997). Esta concepção de tempo aponta para a transformação, o movimento que faz com que uma potencialidade se concretize.

Essa necessidade de se repensar o tempo do currículo para o atendimento escolar da pessoa com Síndrome de Down é referendada por pesquisas que apontam singularidades dessas pessoas com "defasagem na linguagem receptiva, na qual estão envolvidas a memória e o processamento auditivo de informações." (BISSOTO, 2005, p. 84).

Por isso é necessário compreender algumas características presentes no processo de aprendizagem da pessoa com Síndrome de Down para que o seu acompanhamento escolar venha ser adequado às suas necessidades, embora isto não signifique que o ensino a ela direcionado seja inferior aos demais. Por exemplo, de acordo com Mills (2003, p. 235), o processo de alfabetização da pessoa com síndrome deve considerar o seu atraso na aquisição da linguagem, pois "aos seis anos, a criança com SD ainda não adquiriu parte de seu sistema fonológico." Esta autora ainda aponta que o ensino direcionado a pessoas com Síndrome de Down deve considerar também as suas potencialidades com relação a diferentes expressões de artes (música, dança, canto etc.).

Voivodic (2004) discute que em pessoas com Síndrome de Down é comum o déficit de atenção e consequentemente um déficit em relação ao acúmulo de informações na memória imediata o que afeta a produção e processamento da linguagem. 
A criança não reproduz frases, pois retém somente algumas palavras do que ouve. Apresenta também déficit na memória a longo prazo, o que pode interferir na elaboração de conceitos, na generalização e no planejamento de situações. (VOIVODIC, 2004, p. 45).

Por outro lado, por muito tempo não se investiu na elaboração do pensamento conceitual por alunos com Síndrome de Down por se pensar de forma determinista que "os indivíduos com atraso mental podem atingir uma maturidade humana e social dentro das limitações de sua inteligência, embora esta não atinja os níveis formais de abstração.” (MILANI, 2005, p. 55).

Porém, em uma perspectiva sócio-histórico-cultural entende-se que, em todas as situações, as condições para o atraso no desenvolvimento não são determinadas apenas pelo fator biológico, mas também pelo fator ambiental ou sociointeracional. Daí porque se torna importante também conhecer a história familiar das crianças, pois a qualidade na interação com os pais, para o desenvolvimento dessa criança influencia nos aspectos cognitivo, linguístico e socioemocional (VOIVODIC, 2004).

De acordo com Torres González (2002), a educação de pessoas com deficiência está centrada em dois enfoques: o tradicional e o cultural-integrador. O enfoque tradicional se baseia no déficit, ou seja, nos limites que tem a pessoa com necessidade especial de, individualmente, dar as respostas esperadas. $\mathrm{O}$ enfoque cultural-integrador se volta para o currículo como forma de atender às demandas trazidas para a escola para o trabalho com a diversidade.

O enfoque tradicional coloca as falhas no processo de aprender como sendo um problema inerente ao aluno, resultado de sua "deficiência". O segundo enfoque, cultural-integrador, traz para a escola o dever de dar respostas que atendam satisfatoriamente às demandas dos alunos, promovendo a modificabilidade do sujeito, ao longo do processo de desenvolvimento.

A proposta de inclusão colocou para a escola regular o desafio da atenção à diversidade e trouxe como necessidade um currículo que abrangesse o atendimento a esses alunos prevendo a

inserção de todos, sem distinção de condições lingüísticas, sensoriais, cognitivas, físicas, emocionais étnicas, socioeconômicas ou outras e requer sistemas educacionais planejados e organizados que dêem conta da diversidade dos alunos e ofereçam res- 
postas adequadas às suas características e necessidades (BRASIL, 1999, p. 17).

Assim, a escola precisa estar preparada para garantir, entre outras coisas, condições de acesso a sua proposta curricular e, também, a adequação dessa proposta de forma, a atender às necessidades individuais dessa "nova" demanda de alunos. O currículo é o instrumento que a escola possui para adaptar-se às necessidades dos alunos e, portanto, necessita ser flexível e comprometido com uma educação não-segregadora, oferecendo respostas à complexidade de interesses, problemas e necessidades que acontecem na realidade educacional.

Isso significa que para atender à pessoa com Síndrome de Down na escola regular, o currículo precisa ser adaptado, isto é, adequado "às maneiras peculiares de os alunos aprenderem, considerando que o processo de ensino-aprendizagem pressupõe atender a diversificação de necessidades dos alunos na escola." (BRASIL, 1999, p. 15).

Essas modificações nos diversos elementos do currículo para adequá-los às demandas dos alunos com necessidades educativas especiais podem ser feitas para abranger a escola, a turma ou apenas um indivíduo. Também podem envolver ajuste na forma de avaliação, na metodologia, no conteúdo e no tempo. Por exemplo, "as crianças com Síndrome de Down ficam fatigadas com muita rapidez, o que prejudica sua atenção em atividades muito longas." (MILANI, 2005 , p. 71). Isto indica que adaptações curriculares são necessárias para que o seu processo de aprendizagem não fique comprometido.

\section{CONSIDERAÇÕES FINAIS}

A proposta de adaptação curricular baseia-se no pressuposto vigotskiano de que o aprendizado movimenta o desenvolvimento, produzindo uma constante modificabilidade do sujeito e numa visão do desenvolvimento de forma prospectiva, isto é, fundamentada naquilo que pode ser feito, através da interação com outros sujeitos mais maduros da cultura (VYGOTSKY, 1998). Essa compreensão deixa claro que nas modificações curriculares, os procedimentos de mediação efetivados na escola (demonstração, assistência, fornecimento de pistas, instruções) são fundamentais para promover um ensino inclusivo capaz de favorecer o desenvolvimento.

Portanto, vê-se que falar de adaptações curriculares significa falar de uma ação da escola para responder às necessidades de aprendizagem dos alunos, pro- 
movendo modificações necessárias nos elementos do currículo a fim de adequálo às diferentes situações e necessidades de aprendizagem emergidas no grupo ou provenientes de indivíduos específicos.

\section{REFERÊNCIAS}

ALVES, Fátima. Para entender Síndrome de Down. Rio de Janeiro: Wak, 2007.

BISSOTO, Maria Luíza. Desenvolvimento cognitivo e o processo de aprendizagem do portador de síndrome de Down: revendo concepções e perspectivas educacionais. Ciências \& Cognição, v. 4, p. 80-88, mar. 2005. Disponível em: < http:// www.cienciasecognicao.org $>$. Acesso em: 02 abr. 2005.

BRASIL. Secretaria de Educação Fundamental. Parâmetros curriculares nacionais: adaptações curriculares. Brasília, 1999.

CASTRO, Antonilma Santos Almeida. As inferências feitas por crianças com Síndrome de Down na leitura de textos imagéticos. 2002. 124 f. Dissertação (Mestrado em Educação Especial) - Universidade Estadual de Feira de Santana, Feira de Santana, 2002.

CHAMPLIN, Russel Norman.; BENTES, João Marques. Enciclopédia de Bíblia, Teologia e Filosofia. 4. ed. São Paulo: Candeia, 1997. v. 6

MANTOAN, Maria Teresa Eglér. Inclusão escolar: o que é? Por quê? Como fazer? São Paulo: Moderna, 2003.

MILANI, Denise. Down, Síndrome de: como - onde - quando - porque. São Paulo: Livro Pronto: 2005.

MILLS, Nancy Derwood. A educação da criança com Síndrome de Down. In:

SCHWARTZMAN, José Salomão. Síndrome de Down. 2. ed. São Paulo: Memnon; Mackenzie, 2003.

PIMENTEL, Susana Couto. (Con) viver (com) a Síndrome de Down em escola inclusiva: mediação pedagógica e formação de conceitos. 2007. 214 f. Tese (Doutorado em Educação) - Faculdade de Educação, Universidade Federal da Bahia, Salvador, 2007.

TORRES GONZÁLEZ, José Antonio. Educação e diversidade: bases didáticas e organizativas. Porto Alegre: Artmed, 2002.

VOIVODIC, Maria Antonieta Machado de Almeida Inclusão escolar de crianças de crianças com Síndrome de Down. 2. ed. Petrópolis: Vozes, 2004.

VYGOTSKY, Lev Semenovitch Formação social da mente: o desenvolvimento dos processos psicológicos superiores. São Paulo: Martins Fontes, 1998. 


\section{GESTÃO ESCOLAR}





\section{COORDENAÇÃO PEDAGÓGICA E MEDIAÇÃO TECNOLÓGICA - INTERFACE NA PERSPECTIVA DE UMA EDUCAÇÃO INCLUSIVA}

Andréa Direne da Matta Castro

Leliana de Sousa Gauthier

\section{A PESQUISA EM CONSTRUÇÃO}

Este artigo traz uma reflexão a respeito da prática instituinte, no trabalho de coordenação pedagógica, segundo os pressupostos teórico-metodológicos da Análise Institucional (AI) e a perspectiva da educação inclusiva, como objeto de estudo. Tal reflexão integra o bojo de dados parciais da pesquisa Coordenação Pedagógica: um estudo da educação inclusiva na perspectiva da análise institucional no ensino médio, desenvolvido pelo grupo de pesquisa Saberes e Etnicidades vinculado ao Programa de Mestrado em Políticas Públicas, Gestão do Conhecimento e Desenvolvimento Regional.

O propósito é subsidiar a discussão sobre a prática de coordenação pedagógica como elemento fundante para apoiar propostas de educação inclusiva quando a relação entre sujeitos e coletividade encontra-se definida pela possibilidade de reconstituição, reconfiguração de modalidades inovadoras de produção do conhecimento, cada vez mais acessível a um maior número de pessoas em decorrência de novos delineamentos evidenciados pelas Tecnologias de Informação e Comunicação (TIC). 
Ao questionarmos quais práticas a serem instituídas no trabalho de coordenação pedagógica orientam uma efetiva educação inclusiva, estamos especulando acerca das implicações das práticas instituintes. Abordamos os pressupostos teórico-metodológicos da AI, e os fundamentos da educação inclusiva acreditando que é possível apreciar quais traços afetam o imaginário instituinte das práticas educativas.

As reflexões que ora propomos são indicativos da vitalidade da problemática de pesquisa: qual imaginário da prática educativa inclusiva se evidencia no trabalho de coordenação pedagógica? Essa problemática implica em uma hipótese inicial delineada no projeto de pesquisa que fundamenta as discussões aqui desenvolvidas. Pressupõe-se que o imaginário institucional revela a tradição educativa.

O objetivo neste texto é refletir os pressupostos teórico-metodológicos da AI e da Educação Inclusiva de modo a identificar os sentidos da concepção da prática instituinte no trabalho de coordenação pedagógica.

\section{O OBJETO DE ESTUDO: ALGUMAS CONSIDERAÇÕES}

$\mathrm{Na}$ sociedade atual onde o conhecimento passa a ser considerado fator relevante, cabe à coletividade mobilizar-se para a construção de ações e práticas coletivas que envolvam múltiplos sujeitos, que articulem modos de fazer e aprender permanentes, entendendo e defendendo a necessidade e emergência da dimensão social do acesso à educação, ao conhecimento e as TIC como fatores relevantes ao desenvolvimento social, humano e econômico.

A educação inclusiva tem como proposta fundamental o desafio de romper com o preconceito no intuito de superar a anomia e emancipar os sujeitos sociais, o que passa a ser um grande desafio para a educação, uma vez que, pressupõe que a formação dos cidadãos envolva compreender e respeitar a realidade e limite de cada indivíduo, criando e ampliando a idéia de pertencimento e de identidade coletiva consolidando a formação integral destes atores, historicamente excluídos e marginalizados.

Conforme assinala Lourau, cada organização, neste caso, de educação produz uma cultura interna própria, instituindo ações e práticas que exprimem os valores, crenças, conhecimentos e atitudes dos que nela atuam. (ARDOINO, 2003). 
A lógica instituída na educação é a lógica da exclusão, cabe ao trabalho de coordenação pedagógica instituir uma ação que evidencie, na atuação dos profissionais da educação, a construção de práticas que atendam à diversidade, seja cultural, étnica, de gênero, socioeconômica, psicológica ou físico-sensorial.

A prática excludente, institucionalizada, não atende às necessidades e demandas da sociedade contemporânea marcada pela possibilidade comunicacional e, potencializada com a revolução digital e dos meios tecnológicos.

A interface metodológica da AI surge como uma pista para fomentar a auto-análise e a auto-gestão de modo que possa desencadear processos de heteroanálise e hetero-gestão, conforme aponta seu fundador Lourau na possibilidade de construir um ambiente de aprofundamento sobre as relações entre inclusão e educação, igualdade e diferença, na sua complexidade de modo a levar o coletivo social da escola ao exercício crítico, de questionamento e reflexão sobre seu papel como agente da inclusão sócio-cultural de todos os alunos. (ARDOINO, 2003)

Educação inclusiva aqui compreendida, no sentido de atar o indivíduo a um coletivo, conforme assinala Lévy (2000), ressaltando a necessidade de ampliar o acesso à educação e, potencializá-la a partir dos benefícios que as TIC podem proporcionar ao cidadão considerado excluído.

Nesta esperança, a proposta de educação inclusiva é concebida como uma alternativa para promover, por meio da educação, a conscientização do valor positivo da diversidade cultural que possa favorecer o bem-estar das pessoas; a redução das desigualdades sociais e transformar-se num verdadeiro canal de mobilidade social; a educação inclusiva cumpre seu papel na medida em que as pessoas tenham mais do que simples acesso à escola, mas, que possam, principalmente, desenvolver-se de modo pleno e aprender continuamente.

É nesta ótica que compreendemos a educação como condição para o desencadeamento de conhecimento, habilidades e competências, especialmente, pela possibilidade de permitir a emancipação do homem, em resposta ao modelo autoritário de desenvolvimento que tem levado à anomia e à total falta de perspectiva das populações menos favorecidas.

O termo educação é aqui entendido não apenas como sinônimo de escolarização, sobretudo, como ação socializadora cujas orientações possam ser definidas e desenhadas de forma que seja capaz de envolver e transformar a sociedade. 
Neste sentido o trabalho de coordenação pedagógica deverá mediar uma educação para o desenvolvimento social, político, cultural e, também econômico, que represente espaço de emancipação, de transformação e de esperança, que ultrapasse a sua dimensão de mera transmissora de conteúdos e, conforme Freire (1996), que não se limite e a transferir conhecimentos, mas, sobretudo, permita a construção do conhecimento e a convicção de que a mudança é possível.

A expressão Coordenação Pedagógica é percebida a partir dessa concepção como interface de mediação das relações e mudança da escola, segundo Vasconcellos (2002, p. 89), e para quem

O coordenador, ao mesmo tempo em que acolhe e engendra, deve ser questionador, desequilibrador, provocador, animando e disponibilizando subsídios que permitam o crescimento do grupo; tem, portanto, um papel importante na formação dos educadores, ajudando a elevar a consciência $[\ldots .$.$] .$

Embora não seja determinante ou garantidor de desenvolvimento, é preciso considerar que as qualidades das relações e inter-relações sociais (capital social) potencializam o processo de desenvolvimento, se considerarmos que, através da mobilização de forças sociais, solidária e inteligentemente torna-se possível modificar a sociedade, retirando-a do estado de anomia de modo a transformar os cidadãos em sujeitos autônomos do desenvolvimento.

Cabe o resgate de uma educação, como ação estratégica, que tenha como motor a formação, a mobilização e a construção coletiva da consciência crítica e participativa dos sujeitos, para que se tornem atores do seu próprio desenvolvimento.

Acreditamos que o marco significativo da Educação Inclusiva não se dá, apenas, pela incorporação dos modernos recursos tecnológicos, mas, sobretudo, por uma efetiva contribuição na distribuição e expansão da educação.

Cabe lidar com as diversidades, no sentido de resgate dos princípios de uma educação para a formação e o desenvolvimento integral do homem, que vislumbre um futuro promissor para a humanidade, que seja contextualizado, que estimule o desenvolvimento de cidadãos críticos, criativos, atuantes com plena consciência dos seus direitos e deveres, conforme apontam Lastres, Cassiolato e Arroio (2005). 
A metodologia da AI pode representar significativa contribuição neste processo pela possibilidade de fomentar a auto-análise e auto-gestão, sobretudo, pela possibilidade de aumentar o grau de participação e de integração de todos os atores.

Autoanálise e autogestão sob o ponto de vista de Baremblitt (1992) que significam a produção de um saber, do conhecimento acerca de seus problemas, de suas condições de vida, suas necessidades, demandas etc., e também de seus recursos.

\section{PRESSUPOSTOS TEÓRICO-METODOLÓGICOS DA ANÁLISE INSTITUCIONAL}

Instituição representa o conjunto de práticas que formam uma rede simbólica, socialmente sancionada e materializada nos coletivos sociais, onde a partir dos processos de autoanálise e autogestão, a AI permite o posicionamento do ator social diante do instituído.

A proposta da análise institucional é que, criticamente o coletivo social possa propor e articular novos instituintes num processo dinâmico, crítico e consciente, condizente com a nova realidade organizacional de reflexão e partilha de conhecimentos e ideias com a expectativa de promover uma nova cultura da organização.

A análise institucional é uma corrente metodológica de origem francesa, cujo método de abordagem é de intervenção e consiste em analisar as relações e instâncias individuais e coletivas, que se estabelecem no seio das organizações.

Neste contexto a AI se orienta como agente de transformação que leva o coletivo social a analisar os sentidos cristalizados e instituídos de modo a instaurar a auto-análise e auto-gestão buscando desencadear novos instituintes.

Segundo Altoé (2004), para René Lourau, representante da corrente francesa da AI, as manifestações de não-conformidade são elas mesmas reveladoras da natureza do instituído, o que ele denomina de analisador. Neste caso, a educação inclusiva representa o analisador que revela a prática instituída e pressupõe que, a partir do trabalho de coordenação pedagógica é possível perscrutar novos instituintes na compreensão de uma nova educação inclusiva.

A originalidade desse método de intervenção, isto é, a AI, consiste no fato de que o analista, seja, o pesquisador, não é exterior aos grupos, popula- 
ções, organizações, enfim coletividades estudadas. Sua função é provocar e mobilizar todos os atores, para uma ação transformadora da realidade.

A função da AI aqui proposta é, sobretudo, provocar e mobilizar todos os atores, para uma ação-reflexão transformadora, entendendo que a implantação e implementação de propostas de educação inclusiva não poderão ser viabilizadas sem maiores mudanças nas abordagens cultural, de gerenciamento pedagógico e, na estrutura organizacional da escola.

\section{CONSIDERAÇÕES FINAIS}

Sem a pretensão de simplificar a complexa questão que envolve a educação inclusiva, partimos da premissa de que o trabalho de coordenação pedagógica, a partir dos pressupostos metodológicos da AI, pode ser uma pista para o incremento de ações e propostas de uma educação inclusiva, em longo prazo.

Considerando que essas questões envolvem mudança de hábitos, costumes, conhecimentos, valores, habilidades, criatividade e competências, elementos que podem ser potencializados na ação coletiva, vislumbramos uma formação para a autonomia, a partir de uma prática educadora que possibilite a emancipação dos sujeitos, atores sociais, que historicamente se viram conduzidos à anomia, num total processo de exclusão.

A proposta é que a educação, nesta dimensão, pode ser o diferencial na formação de sujeitos preparados não apenas para colaborar, mas, sobretudo capaz de propor ações de desenvolvimento condizentes com as necessidades e realidade em que vive.

Compete, ainda, considerar que há um limite tênue entre uma proposta efetivamente coletiva - que envolve verdadeiramente toda a equipe de todos os setores e esferas da organização - e uma ação impositiva onde não se considera o tempo, características e particularidades de cada equipe e indivíduos, uma vez que proposta de Educação Inclusiva pressupõe sensibilização, adaptação, amadurecimento e a adesão efetiva de todos.

\section{REFERÊNCIAS}

ALTOÉ, S. René Lourau: analista institucional em tempo integral. São Paulo: Hucitec, 2004.

ARDOINO, J. As pedagogias institucionais/René Lourau. Tradução de João Batista Martins e Heliana de Barros Conde Rodrigues. São Carlos: RiMa, 2003. 
BAREMBLITT, G. Compêndio de análise institucional e outras correntes: teoria e prática. Rio de Janeiro: Rosa dos Tempos, 1996.

BAREMBLITT, G. Compêndio de análise institucional. Rio de Janeiro: Rosa dos Tempos, 1992.

FREIRE, P. Pedagogia da autonomia: saberes necessários à prática educativa. São Paulo: Paz e Terra, 1996.

LASTRES, H. M. M.; CASSIOLATO, J. E.; ARROIO, A. (Org.). Conhecimento, sistemas de inovação e desenvolvimento. Rio de Janeiro: Editora da UFRJ; Contraponto, 2005. LÉVY, P. As tecnologias da inteligência: o futuro do pensamento na era da informática. Rio de Janeiro: Editora 34, 1993. Loyola, 2000.

A inteligência coletiva: por uma antropologia do ciberespaço. 3. ed. São Paulo:

VASCONCELLOS. C. Coordenação do trabalho pedagógico: do projeto político ao cotidiano em sala de aula.São Paulo: Libertad, 2002. 



\section{“OLHAR” DE GESTORES SOBRE A INCLUSÃO DE PESSOAS COM DEFICIÊNCIA EM ESCOLAS REGULARES NO VALE DO JIQUIRIÇÁ}

Susana Couto Pimentel Lívia Menezes da Paz

\section{INTRODUÇÃO}

De acordo com o artigo $58^{\circ}$ da atual Lei de Diretrizes e Bases da Educação Nacional, a educação especial é definida como uma "modalidade de educação escolar, oferecida preferencialmente na rede regular de ensino [...]." (BRASIL, 1996). Esta proposição traz para escola regular alguns desafios emergentes tendo em vista a necessidade de implementação dessa legislação e de atendimento a essa nova demanda. Estes desafios envolvem: construir uma escola que atenda a todos; garantir não apenas o acesso à escola, mas a permanência e oferecer uma educação com qualidade voltada para o atendimento às necessidades do educando. Isto implica num processo de adaptação e reestruturação da escola como um todo às demandas dos alunos e não a adequação destes ao que é oferecido pelas instituições de ensino.

Deste modo, a proposta de escola inclusiva requer: a superação de práticas excludentes e da concepção de homogeneização dos grupos; a promoção de acessibilidade arquitetônica; a quebra de barreiras atitudinais e a superação do ensino monológico baseado na transmissão. "O especial da educação traduz-se por meios para atender à diversidade.” (CARVALHO, 1997, p. 59). 
Diante dessa premente necessidade de adequar a escola para receber alunos com deficiência, esta pesquisa, realizada em municípios do Vale do Jiquiriçá, objetivou investigar o perfil e as condições de atendimento às pessoas com $\mathrm{Ne}$ cessidades Educacionais Especiais (NEE) na rede regular de ensino nesta região do estado da Bahia. O Vale do Jiquiriçá faz parte da região econômica do Recôncavo Sul da Bahia e compreende 23 municípios.

De acordo com dados do Censo Demográfico (IBGE, 2000), cerca de $14 \%$ da população brasileira tem algum tipo de deficiência. No Nordeste do Brasil este total atinge 16,8\% da população, sendo este o maior índice dentre todas as demais regiões (Tabela 1). No Vale do Jiquiriçá essa realidade não é diferente, embora não haja dados precisos sobre as deficiências existentes.

\begin{tabular}{|l|c|c|c|}
\hline \multirow{2}{*}{ REGIÕES } & \multicolumn{3}{|c|}{$\begin{array}{r}\text { Proporção da população residente, portadora de pelos menos } \\
\text { uma das deficiências investigadas (\%) }\end{array}$} \\
\cline { 2 - 4 } & Total & Urbana & Rural \\
\hline \multirow{2}{*}{ Norte } & 14,7 & 15,7 & 12,5 \\
Nordeste & 16,8 & 17,0 & 16,3 \\
Sudeste & 13,1 & 13,0 & 13,8 \\
Sul & 14,3 & 13,8 & 16,5 \\
Centro-Oeste & 13,9 & 14,0 & 13,1 \\
Brasil & 14,5 & 14,3 & 15,2 \\
\hline
\end{tabular}

Tabela 1 - Proporção da população residente, portadora de pelo menos uma das deficiências investigadas, por situação do domicílio, segundo as Grandes Regiões - 2000.

Fonte: IBGE, 2000.

Historicamente, as pessoas com deficiência foram excluídas do processo social por não atenderem ao projeto produtivo das diferentes sociedades. Porém, as discussões sobre educação para todos possibilitaram uma movimentação na sociedade mundial rumo a defesa de um processo de educação inclusiva para pessoas com NEE. Este movimento mundial teve alguns marcos históricos 
importantes. Em 1990, durante reunião da Unesco, em Jomtien - Tailândia, foram aprovados os objetivos da educação para todos. Em 1994, em Salamanca - Espanha, a Conferência Mundial sobre Necessidades Educacionais Especiais: acesso e qualidade forneceu elementos para a produção do documento conhecido como Declaração de Salamanca, que estabelece os princípios da inclusão de pessoas com necessidades educacionais especiais. Em 1996, no Brasil a aprovação da Lei n. 9.394 ratifica as conquistas do movimento mundial pela inclusão e qualidade do ensino. Porém, é importante questionar se esse decreto político demolirá tão facilmente as barreiras simbólicas quanto às barreiras materiais existentes na sociedade (JODELET, 2005).

Diante da realidade legal da inclusão no Brasil, a problemática desta pesquisa envolve o atendimento às pessoas com deficiência na escola regular em municípios do Vale do Jiquiriçá, especificamente com relação às deficiências atendidas; às condições de inclusão nas escolas quanto à acessibilidade, barreiras arquitetônicas, adaptações curriculares, barreiras atitudinais, formação do professor e concepção de gestores acerca da inclusão educacional.

\section{O PERCURSO METODOLÓGICO DA PESQUISA}

Essa investigação foi desenvolvida como uma pesquisa exploratória com caráter descritivo-analítico, com vistas a avaliar os processos educacionais inclusivos das diversas deficiências atendidas no Vale do Jiquiriçá. Essa metodologia de pesquisa permite ao pesquisador uma descrição e uma análise do seu campo empírico de modo a conhecê-lo, compreendê-lo para melhor explorá-lo.

Diante da abrangência do Vale do Jiquiriçá, a opção foi de realizar esta pesquisa em $20 \%$ dos municípios desta região, dando preferência aos locais de pertencimento dos alunos do Curso de Licenciatura em Pedagogia da UFRB Campus Amargosa. Deste modo, a investigação foi desenvolvida nos municípios de Amargosa, Mutuípe e Ubaíra. Esta opção vinculou-se a maior viabilidade do desenvolvimento da investigação nestas cidades onde se têm alunos residentes.

Minayo (1992 apud CRUZ NETO, 1994, p. 53), concebe o campo empírico de investigação como "o recorte que o pesquisador faz em termos de espaço, representando uma realidade empírica a ser estudada a partir de concepções teóricas que fundamentam o objetivo da investigação." 
Inicialmente foi feito o levantamento das escolas que atendem a alunos com deficiência, através do Censo Escolar realizado pelas Secretarias de Educação dos municípios envolvidos e pela Diretoria Regional de Educação, DIREC 29. Em seguida, foi levantado junto aos gestores das escolas regulares o perfil das deficiências atendidas nos municípios, caracterizando as condições reais e as necessidades das escolas para melhor atendimento às pessoas com deficiência. Essas etapas contribuíram para análise do processo de atendimento das pessoas com deficiência nas escolas regulares no Vale do Jiquiriçá.

Para a construção dos dados nesses campos empíricos foram utilizados instrumentos de pesquisa como: entrevistas; análise de documentos oficiais como o censo escolar - e questionários para diretores. Através desses instrumentos foi possível obter dados objetivos, estatísticos e subjetivos relacionados "aos valores às atitudes e às opiniões dos sujeitos entrevistados.” (CRUZ NETO, 1994 , p. 58). Os documentos oficiais possibilitaram o acesso a dados importantes tendo a vantagem de serem fontes relativamente estáveis de pesquisa (MACEDO, 2006, p. 108). Os questionários constaram de questões abertas e fechadas com vistas a identificar a concepção dos gestores sobre o processo da inclusão, bem como as necessidades e dificuldades vivenciadas pela escola neste processo.

\section{OS “ACHADOS” PRELIMINARES DA PESQUISA}

Esta investigação foi desenvolvida em 15 escolas da zona urbana e 19 escolas da zona rural totalizando 34 escolas investigadas nos três municípios. Os resultados preliminares da pesquisa apontam que o tipo de deficiência mais frequente nos municípios pesquisados no Vale do Jiquiriçá é a deficiência mental, seguido pela deficiência visual, deficiência física e deficiência auditiva (Figura 1). No entanto, ao tempo em que os gestores afirmam que a própria escola faz o "diagnóstico" dessas deficiências, mesmo em caso de deficiência mental e transtorno de comportamento, eles apontam que não há formação específica dos profissionais da educação nas escolas para atendimento a pessoas com deficiência.

Nesse momento, torna-se importante tecer algumas considerações. Em primeiro lugar, a ausência de um "diagnóstico" preciso das deficiências impede um trabalho pedagógico mais eficaz. Não estamos com isso defendendo o modelo médico que enfatizava as limitações trazidas pela deficiência, mas discutindo que o acesso a bens e serviços, como assistência a saúde, é condição de cida- 
dania, portanto precisa ser garantido a todos os cidadãos brasileiros. Em segundo lugar, precisamos questionar a competência da escola em fazer diagnóstico das deficiências. Por exemplo, como um aluno com baixa visão, sem diagnóstico preciso, pode ser auxiliado em seu processo de inclusão escolar? Não defendemos rotulações que criem estigmas, mas fazemos apologia a que minimamente o cidadão possa ser atendido em suas reais necessidades para que a escola esteja em condições de possibilitar a inclusão favorecendo a permanência e o desenvolvimento desses sujeitos em seu espaço.

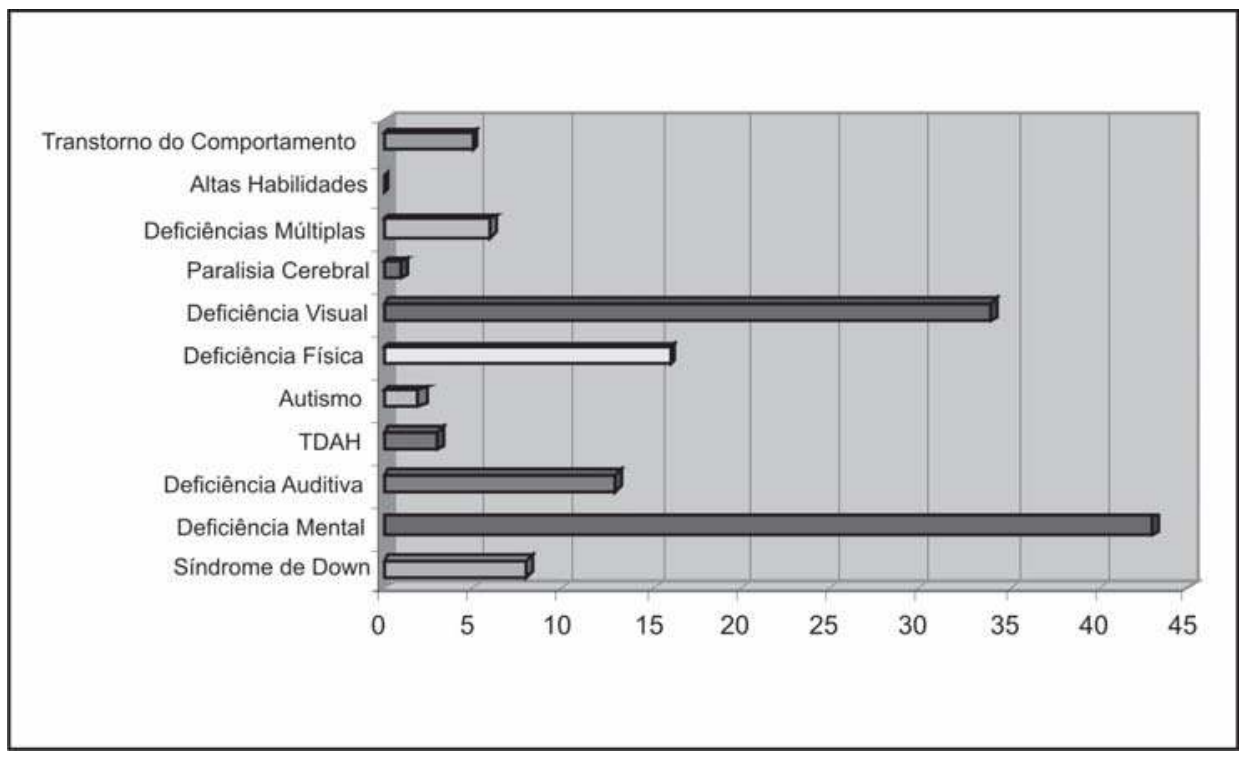

Figura 1 - Tipos de deficiências atendidas em municípios do Vale do Jiquiriçá.

Fonte: Dados da pesquisa.

De acordo com a Figura 2, observa-se que $52 \%$ dos gestores afirmam que o acompanhamento dos alunos com deficiência na escola é feito apenas pelos professores e que estes não contam com o apoio de profissionais especializados e nem com o apoio da família para a realização do trabalho pedagógico.

Essa realidade encontrada também revela as distorções na implementação da política de educação inclusiva, principalmente se comparada ao que está garantido na legislação brasileira que prevê o suporte para que a inclusão aconteça. 


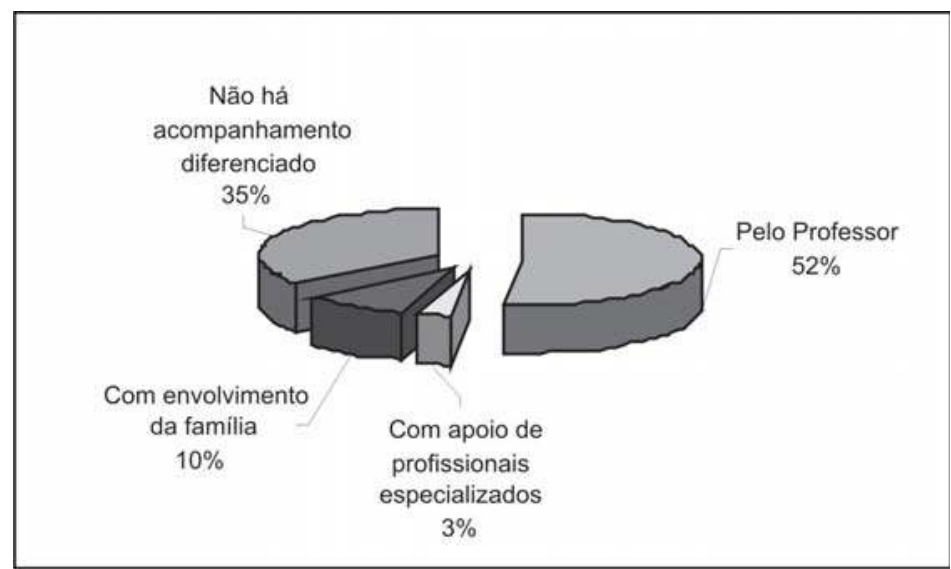

Figura 2 - Acompanhamento aos alunos com deficiência no Vale do Jiquiriçá.

Fonte: Dados da pesquisa.

Diante desse hiato existente entre o que está previsto na legislação e a implementação do processo de educação inclusiva, $68 \%$ dos gestores afirmam que não há qualquer tipo de apoio diferenciado aos professores que atendem a alunos com deficiência. Apenas 16\% dos gestores encaminham os docentes para cursos de formação continuada na área de educação inclusiva. Somente $12 \%$ informam a existência de orientação pedagógica aos professores que trabalham com alunos com necessidades educacionais especiais. Por fim, apenas $4 \%$ das escolas reduzem o número de alunos nas salas que atendem a pessoas com deficiência (Figura 3).

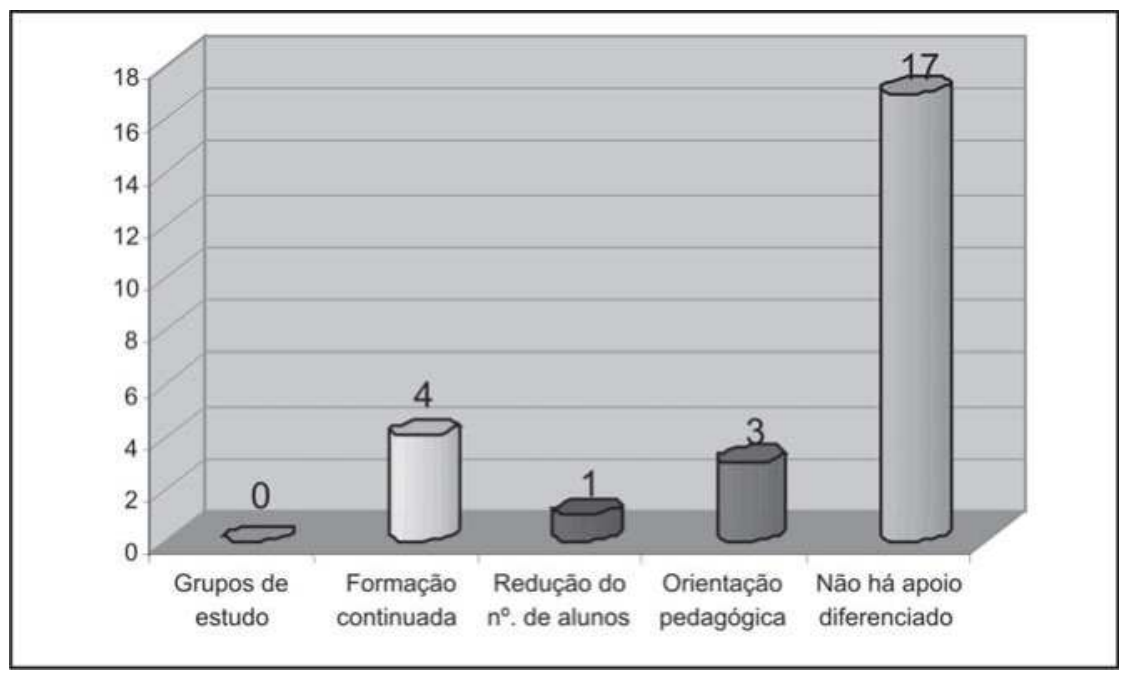

Figura 3 - Apoio aos professores que trabalham com pessoas com deficiência no Vale do Jiquiriçá. Fonte: Dados da pesquisa. 
Mais uma vez esses dados revelam que a operacionalização da inclusão no Vale do Jiquiriçá não tem acontecido de forma concomitante com a elaboração de políticas públicas que favoreçam esse processo. Isso pode comprometer não apenas a eficácia da inclusão, mas sobretudo os resultados das pessoas com deficiência no espaço da escola regular, transformando a proposta da inclusão numa experiência perversa para quem não tem garantia de atendimento às necessidades mínimas de acessibilidade à escola e ao currículo.

Observa-se na Figura 4 que a efetivação da política de educação inclusiva no Vale do Jiquiriçá remete a barreiras para que essa prática promova a qualidade na educação. De acordo com $51 \%$ dos gestores, a maior barreira para que a inclusão seja uma realidade é a falta de formação dos professores para o trabalho com a diversidade. Enquanto que $33 \%$ consideram que a ausência de recursos materiais impede o processo de educação inclusiva.

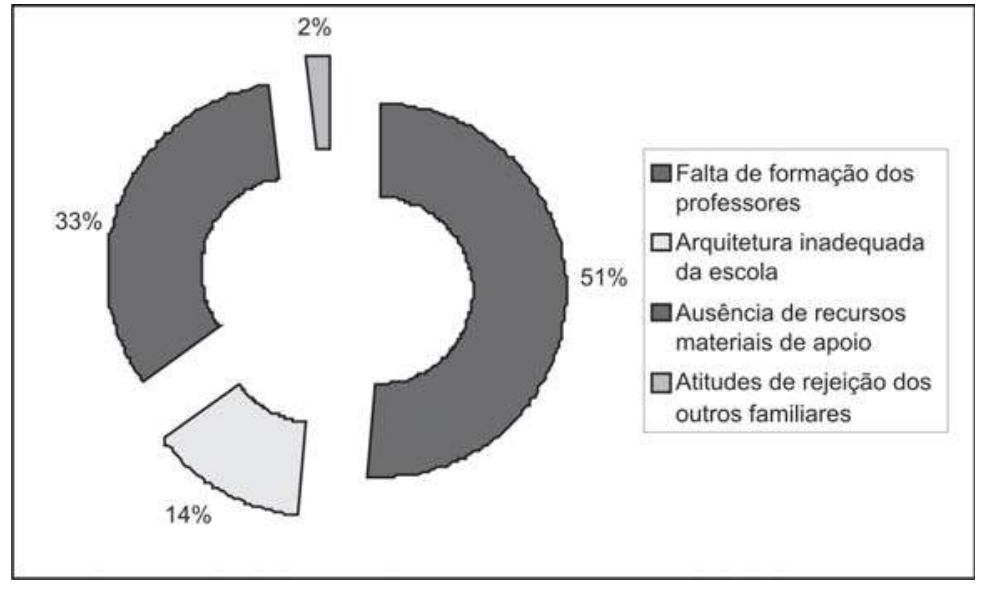

Figura 4 - Barreiras para inclusão nas escolas do Vale do Jiquiriçá.

Fonte: Dados da pesquisa.

Diante disso, apenas $22 \%$ dos gestores se mostram favoráveis à educação inclusiva sem restrições. Dos $74 \%$ que afirmam ser favoráveis colocam restrições como: a existência de apoio de equipe multidisciplinar, realização de cursos de formação continuada do professor e $4 \%$ colocam-se favoráveis à inclusão apenas em casos de deficiência física. Os $4 \%$ restantes são contrários a inclusão (Figura 5). 


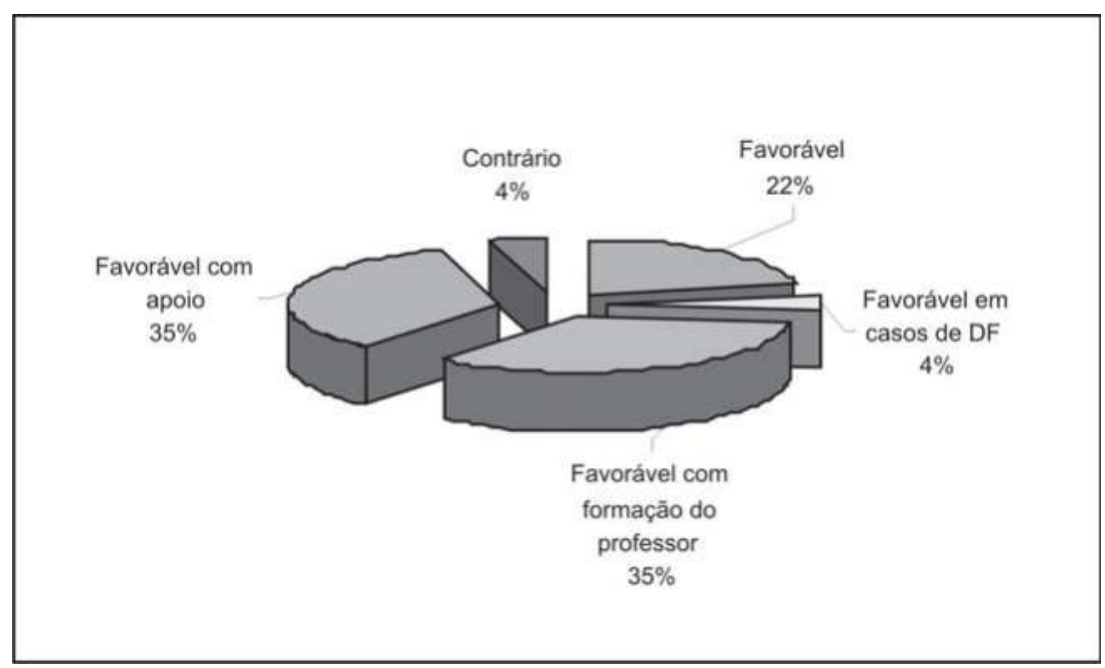

Figura 5 - Concepção dos gestores sobre a inclusão educacional no Vale do Jiquiriçá. Fonte: Dados da pesquisa.

\section{CONSIDERAÇÕES FINAIS}

A análise dos dados construídos durante esta investigação possibilita o desvelamento e a compreensão da realidade da implementação da inclusão de pessoas com deficiência em escolas regulares no Vale do Jiquiriçá.

Diante da realidade encontrada é importante tensionar a tentativa de implementação de inclusão escolar sem que se garantam fatores imprescindíveis. Em primeiro lugar, a operacionalização da educação inclusiva requer que se inicie concomitantemente um processo de transformação social, tendo em vista que a escola é um microespaço da sociedade e que esta não é inclusiva em suas práticas. Em segundo lugar, a inexistência de políticas públicas que viabilizem a inclusão educacional dificulta a implementação da mesma. Tais políticas devem envolver a formação do professor, a garantia de acessibilidade ao espaço escolar e ao currículo, bem como o acesso a recursos materiais e humanos, como impressora Braille, ampliação de textos, intérprete da Língua Brasileira de Sinais (Libras), carteiras adaptadas, dentre outros, que favoreçam o processo de aprendizagem do aluno com deficiência.

Espera-se que o reconhecimento desta realidade possibilite um maior conhecimento com vistas à elaboração de políticas públicas de atendimento a pessoas com necessidades educacionais especiais nesta região do estado da Bahia. 


\section{REFERÊNCIAS}

BRASIL. Lei n. 9.394, de 20 de dezembro de 1996. Estabelece as diretrizes e bases da educação nacional. Brasília, 1996. Disponível em: < http://www.planalto.gov.br/ ccivil_03/ Leis/ L9394.htm\#art92>. Acesso em: 15 set. 2007.

CARVALHO, Rosita Edler. A nova LDB e a educação especial. Rio de Janeiro: WVA, 1997.

CRUZ NETO, Otávio. O trabalho de campo como descoberta e criação. In: MINAYO, Maria Cecília de Souza. Pesquisa social: teoria, método e criatividade. Petrópolis: Vozes, 1994.

DECLARAÇÃO de Salamanca. Sobre princípios, políticas e práticas na área das necessidades educativas especiais. 1994. Disponível em: < http://portal.mec.gov.br/seesp/arquivos/pdf/ salamanca.pdf $>$. Acesso em: 21 out. 2009.

JODELET, Denise. Loucuras e representações sociais. Petrópolis: Vozes, 2005.

IBGE. Censo Demográfico. 2000. Disponível em: < http://www.ibge.gov.br/ibgeteen/ datas/deffisica_nacional/especial.html>. Acesso em: 22 mar. 2007.

MACEDO, Roberto Sidnei. Etnopesquisa crítica, etnopesquisa formação. Brasília: Líber Livro, 2006. 



\title{
ORIENTAÇÕES PARA O PLANEJAMENTO \\ DO ENSINO-APRENDIZADO DA \\ NATAÇÃO PARA CRIANÇAS NA \\ PERSPECTIVA DA INCLUSÃO
}

\author{
Suzana Alves Nogueira \\ Gilmar Mercês de Jesus \\ João Danilo Batista de Oliveira \\ Admilson Santos \\ Sandra Regina Rosa Farias
}

\section{INTRODUÇÃO}

A cada dia, percebe-se o aumento do número de pessoas que possuem algum tipo de deficiência se envolvendo em diversas formas de atividades físicas e esportivas, considerando os inúmeros benefícios possibilitados pela prática dessas atividades na recuperação das habilidades motoras e, também, pelo bemestar que elas proporcionam (LAVOLE et al., 1992 apud TSUTSUMI, 2004). Segundo Costa (2002 apud TSUTSUMI, 2004) a exclusão desses indivíduos da prática de atividades físicas ou do esporte pode levar à diminuição da aptidão física, da eficiência dos movimentos executados e da socialização.

Os dados divulgados pelo IBGE no Censo de 2000 revelam um aumento na população total de deficientes no Brasil, registrando cerca de $14,5 \%$ da população com alguma forma de deficiência, isto é, aproximadamente $24,5 \mathrm{mi}$ lhões de brasileiros.

As pessoas com deficiência, por muito tempo, viveram em situação de total exclusão social, processo tão antigo quanto à socialização do homem, pois 
desde os primórdios da sociedade as pessoas com algum tipo de necessidade especial são inabilitadas, marginalizadas, vivem sem respeito, sem direitos e sem liberdade (MACIEL, 2003). Durante um longo período, a deficiência foi considerada como vingança dos deuses, como algo impuro, obra dos maus espíritos, abominações do corpo e pecado, o que explica, nas civilizações antigas e até mesmo em algumas sociedades tribais da atualidade, a comum eliminação dos indivíduos que nascem com alguma deficiência (FERREIRA; GUIMARÃES, 2003).

Nos últimos anos essa realidade vem sendo modificada através da tentativa de implementação da inclusão social, que objetiva resgatar o respeito humano e a dignidade para possibilitar o desenvolvimento pleno das pessoas com necessidades especiais (MACIEL, 2003). Nesse sentido e de acordo com Alves e Duarte (2005), o processo de inclusão social objetiva construir uma sociedade capaz de promover a participação concreta das pessoas com necessidades especiais, defendendo o oferecimento das condições necessárias para que todos possuam a oportunidade de serem agentes dentro do contexto em que estão inseridos.

Embora o discurso acerca da inclusão esteja sendo difundido e defendido em vários segmentos da sociedade, principalmente no que se refere à defesa da pessoa deficiente (LUZ, 2003; CRUZ, 2005), ainda se verifica uma dificuldade para se efetivarem suas proposições e ações, o que gera a necessidade transformar práticas sociais, muitas vezes, excludentes e discriminatórias.

De acordo com Carmo (1991 apud SANTOS et al., 2006) os indivíduos que apresentam algum tipo de deficiência necessitam se envolver em práticas esportivas e de lazer da mesma maneira que as pessoas consideradas normais. Contudo, observa-se que o esporte praticado pelas pessoas com deficiência também tem apresentado caráter excessivamente técnico, mesmo quando praticado por crianças. Segundo Barros (1993 apud BRAZUNA; CASTRO, 2001), no esporte de alto nível há a busca do rendimento máximo do ser humano atleta, o que o torna excludente, oferecendo oportunidades a um número mínimo de pessoas deficientes envolvidas. Os treinadores que trabalham com deficientes se envolvem pouco na defesa do esporte inclusivo, o que pode ser devido ao descrédito na mudança do modelo excludente do esporte, em que as modalidades são praticadas em locais segregados e o nível técnico exigido muitas vezes não é compatível com o dos deficientes (LUZ, 2003).

Por suas características peculiares, Luz (2003) e Souza (1999) destacam que a natação é uma das atividades mais adequadas para se efetivar o processo 
de inclusão social de pessoas deficientes, inclusive crianças, no esporte. Não obstante, no ensino-aprendizagem da natação, também tem sido destacada ultimamente a preocupação excessiva com a busca da excelência técnica individual, em cada estilo formal de execução (Crawl, Costas, Borboleta e Peito), mesmo quando ensinada às crianças (CATTEAU; GAROFF, 1990; ZULLIETTI; SOUSA, 2002; FREIRE; SCHWARTZ, 2005a; FERNANDES; COSTA, 2006; MOISÉS, 2005). O que predomina no ensino-aprendizagem é a alta intensidade dos exercícios para adquirir a técnica perfeita, não considerando as etapas do desenvolvimento infantil durante este processo (SANTOS, 1996; XAVIER FILHO; MANOEL, 2002; MANOEL, 1995 apud FREIDENHEIM; GAMA; CARRACEDO, 2003).

No que se refere à natação praticada por crianças com alguma deficiência, é necessário ter o entendimento de que o meio aquático é um local para vivências corporais e experiências motoras. Além disso, constitui-se um meio favorável para a integração das deficientes com as não-deficientes, o que consequentemente fortalece o rompimento de barreiras socioculturais (PENAFORT, 2001).

De forma geral, ao se fazer um resgate histórico dos métodos empregados no processo de ensino-aprendizagem da natação, evidenciam-se dois aspectos principais: 1) a redução do conceito de nadar às técnicas dos estilos formais da natação e a preocupação com o aprendizado por simples repetição de gestos motores, e; 2) a conduta disciplinar tradicional do processo de treinamento de uma modalidade esportiva.

Assim, este trabalho tem o objetivo de revisar as características das metodologias empregadas no ensino-aprendizado da natação convencional e da natação adaptada, principalmente em produções nacionais, abordando sistematicamente seus objetos de ensino, objetivos de ensino-aprendizagem, conteúdos, matriz teórico-metodológica, estratégias de ensino e formas de avaliação. A partir disso, é proposto um conjunto de orientações para auxiliar o planejamento do processo de ensino-aprendizagem da habilidade de nadar para um grupo misto de crianças, na perspectiva da inclusão social.

\section{DISCUSSÕES RECURSIVAS, PORÉM AINDA LATENTES SOBRE ENSINO-APRENDIZADO DA NATAÇÃO}

Ao fazer uma análise histórica dos métodos de ensino empregados na natação, observa-se o pioneirismo dos militares no ensino sistemático dessa 
modalidade esportiva (SANTOS, 1996), momento no qual a prática da mesma passou a exigir uma conduta disciplinar (PEREIRA, 2001). Ainda de acordo com Santos (1996), a herança militarista sustenta uma pedagogia na qual a aprendizagem da natação é realizada através de métodos mecânicos sem ter uma preocupação com as fases do desenvolvimento neuro-motor da criança. Esse modelo de ensino é baseado na cópia de movimentos técnicos, caracterizando-o como mecanicista e detalhista (PEREIRA, 2001; FUGITA, 2003; LUZ, 2003; BONACELLI, 2004; LIMA, 1999 apud BRITO, 2005; MOISÉS, 2005; FERNANDES; COSTA, 2006). Além disso, a aula dentro da perspectiva militarista é comandada, na maioria das vezes, por uma voz agressiva e autoritária (SANTOS, 1996).

Ainda hoje existem professores de natação que adotam essa metodologia de ensino que Machado já denunciava em 1978 e isto persiste, seja por falta de conhecimento ou por tradicionalismo. Ainda de acordo com esse autor, é percebido que muitos erros cometidos nas primeiras tentativas de ensino dessa modalidade subsistem nos dias atuais, como se fossem leis para alguns professores seguirem (MACHADO, 1978). Isso demonstra que muitos professores de natação não ampliam sua prática pedagógica e insistem em seguir métodos totalmente ultrapassados.

Para Escobar (1985) a natação deve promover a liberdade de movimento, a criatividade, a espontaneidade e não permitir que a mecanização e a racionalização do movimento inibam esses aspectos, bem como seu sentido e significação. De acordo com Bonacelli (2004), a importância do contato do corpo com a água reside no prazer que ele proporciona, podendo influenciar nas relações do sujeito com o mundo.

De acordo com Santiago e Tahara (2007), o professor de natação que atualmente insiste em limitar a sua prática pedagógica apenas ao ensino dos quatro estilos formais de execução e não procura a diversificação de conhecimentos, não tem a noção da riqueza que o ato humano de nadar pode proporcionar às crianças. É necessário que os professores percebam que têm uma grande parcela de responsabilidade na escolha das estratégias de ensino, as quais podem se constituir em experiências positivas ou negativas para seus alunos, pois a compreensão do meio aquático pelo aprendiz depende também do método de ensino que o professor adota. Um comportamento altamente técnico pode ser mecanizado e, desprovido de significado para o aluno (FUGITA, 2003).

Para Damasceno (1997) não é mais admissível que a natação permaneça reduzida a esse conceito puramente mecanicista no qual a sua prática vise ape- 
nas desempenhos imediatos. Por isso algumas propostas pedagógicas mais conscientes e motivadoras estão surgindo no âmbito da natação infantil, sustentadas não só pela visão tecnicista, mas sim na aprendizagem social e mediada por elementos culturais dentro de uma perspectiva lúdica, na qual o ensino da habilidade de nadar e das técnicas da natação sejam feitos de forma prazerosa, privilegiando a criatividade, a espontaneidade e a afetividade, buscando o desenvolvimento mais integral do ser humano (FREIRE; SCHWARTZ, 2006). A ludicidade no meio líquido é o novo olhar sobre a prática pedagógica da natação (SANTIAGO; TAHARA, 2007).

Nos dias atuais a natação como prática voltada para a pessoa com deficiência deve ser utilizada como meio de ação mais global, ou seja, um dos instrumentos pedagógicos que permite que o deficiente conheça a si mesmo e se aceite, ajustando sua conduta às exigências do meio social (ESCOBAR, 1985).

Para Strohkendl (1986 apud SOUZA, 1994) a aprendizagem da natação para os deficientes é entendida como experiências no meio líquido, permitindo adaptações das funções vegetativas do corpo, do esquema corporal, dos movimentos voluntários, além da redução dos temores como medo e estresse. Escobar (1985) situa o processo de ensino-aprendizagem da natação na perspectiva estrutural-funcional visto que o princípio vital será favorecer a organização das estruturas através de situações problemas que propiciem a sua funcionalidade. Essa visão estrutural-funcional proverá consequências educativas para as pessoas deficientes e as ditas normais.

Segundo Escobar (1985), a metodologia de ensino da natação não deve ser baseada em listas de exercícios formulados e sequências de movimentos, e sim em solução de problemas e em situações que permitam a espontaneidade de cada grupo de alunos. Outro fator importante no ensino às pessoas com algum tipo de deficiência é que o professor não exija e nem cobre resultados imediatos dos alunos, já que essa cobrança pode fazer com que o aluno fique estressado e diminua seu rendimento. Portanto, o professor precisa adaptar os procedimentos, técnicas e recursos à capacidade peculiar de cada aluno, seja nos programas de curto ou longo prazo.

A problemática da pedagogia da natação também é enfatizada às pessoas com deficiência (BRITO, 2005) e, portanto, faz-se necessário uma discussão que contemple a possibilidade do nadar pelos deficientes tendo uma pedagogia de ensino-aprendizagem compatível com as potencialidades e limitações impostas por cada deficiência. Por isso os trechos seguintes abordarão acerca das 
estratégias metodológicas para o ensino da natação para pessoas com deficiência e as peculiaridades em cada tipo de deficiência.

O ensino-aprendizado da natação aplicada às pessoas com vários tipos de deficiência é um processo valioso de vivências e desafios no meio aquático, tanto para os alunos quanto para os professores (ESCOBAR, 1985; CATTEAU; GAROFF, 1990; VELASCO, 1997). As atividades realizadas na piscina permitem que os alunos, principalmente os alunos deficientes, movimentem-se livremente, explorem o meio líquido e vivenciem experiências motoras desconhecidas (ADAMS et al., 1985 apud PENAFORT, 2001).

\section{PROPOSTA PARA O ENSINO-APRENDIZADO DA NATAÇÃO NA PERSPECTIVA DA INCLUSÃO}

As características motoras, cognitivas e afetivas das crianças com deficiência exigem adaptações em todo o processo de ensino-aprendizagem, as quais vão desde a metodologia, estratégias de ensino e materiais utilizados às atitudes do próprio professor. Pode-se reconhecer um conjunto de situações-problema atrelado ao ensino-aprendizado da natação na perspectiva da inclusão e que precisam ser considerados: como ministrar aulas de natação para crianças deficientes? Como ministrar aulas para um grupo misto de crianças (as ditas normais juntamente com aquelas com deficiência) em uma mesma turma? Como estimular o aprendizado e desenvolvimento da habilidade de nadar sem restringir a sua prática a uma abordagem técnico/esportiva?

Esses aspectos aliam-se a ainda evidente escassez de referências na literatura sobre um ensino da natação na perspectiva da inclusão social. São recorrentes os textos em que há a consideração segmentada da natação com sua prática voltada para o desempenho atlético. A partir da análise feita das características das metodologias empregadas no processo de ensino-aprendizagem da natação convencional e adaptada e a partir das contribuições das leituras de textos sobre inclusão social e Educação Física e esporte adaptado, foram sistematizados alguns princípios considerados adequados para a elaboração de estratégias inclusivas para o ensino/desenvolvimento da habilidade de nadar para crianças (as ditas normais juntamente com as com deficiência), com o objetivo de possibilitar às mesmas um aprendizado que supere o modelo desportivo da natação e permita um nadar diversificado, lúdico, criativo, independente, com respeito às diferenças e sem objetivar apenas a execução da técnica perfeita dos estilos formais da natação. 
Para se pensar na elaboração de orientações para o ensino-aprendizagem da habilidade de nadar para crianças, alguns princípios fundamentados em conhecimentos teóricos são importantes. Nesse sentido, e com base nas contribuições dos trabalhos revisados esses princípios são: 1) objeto de ensino; 2) diretrizes fundamentais para o ensino; 3) objetivo de ensino; 4) opção teóricometodológica; 5) estratégias de ensino; 6) conteúdos e; 7) avaliação. No caso específico da proposta inclusiva defendida nesse trabalho, discorre-se a seguir sobre os princípios supracitados.

1) No que se refere ao objeto de ensino, tem-se a habilidade de nadar, que é entendida como o conjunto de diversas experiências corporais vivenciadas no meio líquido que resultam em locomoção autônoma, livre, segura e prazerosa com um bom equilíbrio (estático e/ou dinâmico) e controle da dinâmica respiratória. Os conhecimentos acerca da sequência do desenvolvimento motor aquático podem subsidiar a estruturação adequada das aulas por levarem em consideração as fases de desenvolvimento da habilidade de nadar, as quais já foram descritas anteriormente por Xavier Filho e Manoel (2002).

2) As diretrizes fundamentais para o ensino nessa proposta versam sobre a consideração do sujeito aprendiz, o espaço da aula, características das atividades desenvolvidas, a postura do professor, a utilização de equipamentos de flutuação e a organização dos alunos e das atividades por níveis de aprendizado/ desenvolvimento.

Assim, o sujeito aprendiz é considerado sob a perspectiva de sua totalidade e, por isso, a sistematização dos programas de ensino do nadar deve levar em consideração aspectos referentes aos três domínios do comportamento que são o motor, o socioafetivo e o cognitivo, como também pontuam Freudenheim, Gama e Carracedo (2003) e, anteriormente, Queiroz (1998). No aspecto motor encontram-se todas as diversificadas formas de movimento; no afetivo-social estão algumas atitudes, como confiança, autonomia, segurança e motivação; e no campo cognitivo encontram-se vários conhecimentos que são apreendidos pelos alunos, como a percepção do seu próprio nadar (FUGITA, 2003), alguns conhecimentos básicos da fisiologia e da biomecânica (FREIDENHEIM; GAMA; CARRACEDO, 2003).

Ainda fazendo referência às diretrizes fundamentais para o ensino, outro ponto importante é que a aula é vista como um espaço social inclusivo em que todas as pessoas podem participar e que por isso, nele devem estar presentes todos os indivíduos que constituem a diversidade da sociedade, como os deficientes, sejam eles físicos, mentais, auditivos ou visuais. Portanto, todas as ativi- 
dades desenvolvidas precisam apresentar adaptações nas suas regras, nos materiais e nas metodologias de ensino com o objetivo de que todas as pessoas envolvidas possam ter a participação efetiva no processo de ensino-aprendizagem. $\mathrm{O}$ professor é considerado parte integrante do processo educativo com o mesmo nível de importância dos alunos, atuando como provocador, problematizador, mediador, estimulador das situações de ensino-aprendizado.

Deve-se destacar nesse processo de ensino-aprendizado a organização dos alunos e das atividades desenvolvidas nas aulas por níveis de aprendizado/desenvolvimento, respeitando as características funcionais de cada tipo de deficiência. Isso é importante visto que, se as crianças da mesma turma encontram-se no mesmo nível - segundo suas características de desenvolvimento psicomotor, maturacional e do comportamento motor aquático - é possível fazer um planejamento que contemple a todos os alunos indistintamente e, mesmo que alguns apresentem algumas limitações impostas pela deficiência, eles estarão na mesma etapa dos demais alunos, tendo condições compatíveis de aprendizado. Identificando em que fase da sequência do desenvolvimento motor aquático os alunos se encontram há uma facilidade maior na tomada de decisão acerca de qual conteúdo ensinar e de como ensiná-lo.

Concordando com Duarte (2005), é relevante que se considere o fato de que o professor deve primeiro conhecer o educando e ter os conhecimentos básicos acerca dele, se o mesmo tiver alguma necessidade educativa especial, é preciso que se tenha o entendimento das características da deficiência, a idade em que a mesma se manifestou, se foi repentina ou gradativa, se é permanente ou transitória, quais as funções que estão comprometidas, quais as limitações e potencialidades do sujeito aprendiz para, a partir daí, saber quais as estratégias a serem adotadas. Além disso, é necessário que o professor considere alguns aspectos importantes para minimizar as barreiras para a aprendizagem, como a capacidade linguística do aluno e o tipo de ajuda a ser prestada para a execução de algum movimento.

3) O objetivo de ensino dentro dessas orientações, portanto, é estimular o aprendizado/desenvolvimento da habilidade de nadar no sujeito aprendiz, respeitando as suas especificidades motoras, cognitivas e socioafetivas.

4) A metodologia é fundamentada na abordagem construtivista, em que a construção do conhecimento se dá a partir da interação do sujeito com o mundo e na solução de problemas. Essas situações de resolução de problemas são promotoras de aprendizagem na medida em que, ao mobilizar os conhecimentos prévios dos sujeitos, trazem simultaneamente um desafio na direção da 
eficiência e da satisfação. A mediação entre o interesse pessoal e o valor socialmente atribuído constitui, a cada situação, motivação para a aprendizagem (BRASIL, 1997). Faz-se necessário propor tarefas lúdicas educativas e cada vez mais complexas e desafiadoras, visando à construção do conhecimento. Nesse sentido, por tratar-se de crianças, deve-se resgatar a cultura de jogos e brincadeiras no processo de ensino-aprendizagem, pois estes podem ser considerados como principais meios para ensinar crianças. Enquanto a criança brinca num ambiente lúdico e prazeroso, ela aprende (DARIDO, 1998).

5) Em relação às estratégias de ensino, as situações-problema e a utilização dos jogos como recurso, apresentam-se adequadas à opção teórico-metodológica e em acordo com as perspectivas lúdicas no ensino da natação para crianças apontadas por Queiroz (1998), Freire e Andries (2001), Freire e Schwartz (2005a, 2005b), Moisés (2005), Santiago e Tahara (2007). O jogo para as crianças é considerado uma fonte de prazer e descoberta, visto que através dos jogos é que as crianças constroem seu conhecimento em relação ao mundo dos objetos e da linguagem (SANTOS, 1996). No ensino da natação lúdica o jogo pode proporcionar a experimentação e a vivência de diversas situações prazerosas; a motivação para que as crianças participem de forma integral da aula; as brincadeiras podem diminuir possíveis sensações de medo no meio líquido e ajudar na construção do convívio afetivo e expressão corporal das crianças.

6) As orientações para os conteúdos indicam a sua hierarquização, dos menos complexos para os mais complexos, respeitando o nível de aprendizado/ desenvolvimento motor, socioafetivo e cognitivo das crianças, assim como as características funcionais de cada tipo de deficiência. Um aspecto que é apontado por Ferraz (1996 apud FERNANDES; COSTA, 2006) é que ao falar em uma pedagogia da natação é preciso levar em consideração que o aprendizado da natação tenha componentes educativos conceituais, procedimentais e atitudinais. Se esses componentes não forem levados em conta o aprendizado do nadar se limita ao domínio técnico dos estilos formais da natação (FERNANDES; COSTA, 2006).

No que se refere aos conteúdos conceituais pretende-se que os alunos aprendam o significado de um nadar diversificado, prazeroso, autônomo, criativo e lúdico e que eles se apropriem das técnicas dos estilos da natação com a possibilidade de ressignificá-las de acordo com suas necessidades. Ademais, é importante que se desenvolva nos alunos o senso de que todos implicados no processo de ensino-aprendizado possuem igualdade de direitos - na aula e na sociedade de forma geral - e que na sociedade há pessoas com necessidades 
especiais, com deficiências físicas, mentais, auditivas e visuais e que fará parte do seu cotidiano tratá-las com respeito e dignidade.

Os conteúdos procedimentais associados ao aprendizado e desenvolvimento da habilidade de nadar são aqueles associados ao fazer do: controle postural voluntário, que resulta na obtenção de equilíbrio estático e/ou dinâmico; controle respiratório voluntário e movimentos corporais coordenados, que resultarão em locomoção, expressos em conjunto ou separadamente, em manifestações especializadas - como o nado Crawl, o Costas, o Borboleta e o Peito e as técnicas de saídas e viradas - ou não-especializadas.

No que se refere aos conteúdos atitudinais, sabe-se que ao desenvolver as aulas para as crianças é possível também desenvolver ou ressignificar nelas algumas atitudes, normas e valores, como: a cooperação, a honestidade e o senso de coletividade; a importância do diálogo na resolução de problemas, a liberdade de expressão e o autocontrole; o trabalho em grupo; a solidariedade; o respeito às regras e as dificuldades dos colegas na realização das atividades; o respeito às diferenças e à dignidade da pessoa humana, valorizando e preocupando-se com seus pares.

A conscientização e o estímulo à adoção dessas atitudes durante as aulas são de grande importância, pois, muitas vezes, podem ser perceptíveis nas aulas diversas situações de rejeição dos alunos ditos normais em relação aos deficientes, já que os mesmos podem não estar acostumados a ver pessoas com deficiência em turmas regulares. Então, pensando na inclusão social, faz-se necessário que ocorram transformações na mentalidade e nas atitudes de todas as pessoas, inclusive da própria pessoa deficiente. E essas mudanças podem acontecer também nas aulas de natação, fazendo com que os alunos aceitem e valorizem as diferenças individuais e aprendam a conviver dentro da diversidade humana.

7) Ao pensar nas formas de avaliação, Freudenheim, Gama e Carracedo (2003) mencionam que a avaliação tem o objetivo de acompanhar o processo de aprendizagem individual. Diante dos trabalhos revisados referentes às metodologias empregadas no ensino da natação convencional e adaptada, foi percebida a escassez de métodos de avaliação do aprendizado, sendo raros os autores que mencionaram esse aspecto. A falta de um critério avaliativo nas propostas metodológicas do ensino da habilidade de nadar é um dos grandes entraves do processo de ensino-aprendizagem, uma vez que o mesmo facilita o entendimento do cumprimento ou não dos objetivos traçados. Por isso a existência de uma proposta de avaliação é de fundamental importância, visto que é uma possibilidade de indicar caminhos mais adequados e mais satisfatórios para 
a ação que está sendo desenvolvida. Ao avaliar podem ser identificadas dificuldades coletivas e individuais e se apontar meios para saná-las; identificar os avanços e regressos dos alunos e verificar se a metodologia adotada está favorecendo a aprendizagem.

Portanto, a forma de avaliação aqui sugerida, em concordância com Freudenheim, Gama e Carracedo (2003) é a ficha de avaliação individual, utilizada para avaliar aspectos motores, afetivo-sociais e cognitivos sendo aplicada em cada aula ou blocos de aulas para verificar o nível de aprendizagem/desenvolvimento alcançado pelos alunos durante a realização das atividades.

No que diz respeito à avaliação do aspecto afetivo-social os fatores a serem observados são: autonomia, participação nas atividades, responsabilidade, cooperação, socialização, respeito aos colegas e professores, criatividade, solução de problemas, interação social, respeito às normas e condutas, confiança para enfrentar os desafios, motivação e envolvimento nas atividades em grupo. No aspecto motor é necessária uma avaliação da evolução do nadar, enfocando as habilidades que o constituem: controle postural estático e dinâmico voluntários, controle respiratório voluntário, movimentos coordenados de braços e pernas, os quais, quando combinados, resultam nas manifestações não especializadas até as especializadas do nadar humano.

\section{CONSIDERAÇÕES FINAIS}

Através deste estudo pretendeu-se contribuir para elaboração de propostas metodológicas de ensino-aprendizagem da natação, identificando princípios para a sistematização de estratégias inclusivas de ensino-aprendizado para crianças ditas normais e deficientes, propiciando às crianças com necessidades especiais melhores condições para a sua efetiva participação nas aulas. Em relação ao impacto científico desta pesquisa, a revisão de literatura feita, revelou que o tema em questão é pouco pesquisado pela comunidade científica, pois estudos referentes à natação inclusiva e à sistematização de uma metodologia do ensino da natação em turmas mistas foram bastante escassos. Foram encontrados inúmeros estudos, nos quais, o ensino da natação é segmentado e excessivamente técnico e desportivizante. Por isso, a publicação das reflexões feitas nesse trabalho entre a comunidade científica e professores de Educação Física e natação pode possibilitar o retorno social às crianças deficientes, fazendo com que as mesmas tenham a oportunidade de vivenciar um aprendizado/desenvolvimento do seu comportamento motor aquático de forma diversificada, criativa, autôno- 
ma, com respeito às diferenças e sem as pressões ocasionadas pelo objetivo do desempenho técnico-esportivo, muito comum na prática da natação.

\section{REFERÊNCIAS}

ALVES, M. L. T.; DUARTE, E. A inclusão do deficiente visual nas aulas de educação física escolar: impedimentos e oportunidades. Maringá, v. 27, n. 2, p. 231-237, 2005.

ASSOCIATION OF SWIMMING THERAPY. Natação para deficientes. 2. ed. São Paulo: Manole, 2000.

BONACELLI, M. C. L. M. A natação no deslizar aquático da corporeidade. 2004. Tese (Doutorado em Educação Física) - Universidade Estadual de Campinas, Campinas, 2004.

BRASIL. Ministério da Educação. Secretaria de Educação Fundamental. Parâmetros curriculares nacionais: educação física. Brasília, DF, 1997.

BRAZUNA, M. R.; CASTRO, E. M. A trajetória do atleta portador de deficiência física no esporte adaptado de rendimento: uma revisão da literatura. Motriz, v. 7, n. 2, p. 117-123, jul./dez. 2001.

BRITO, C. A. F. O campo atrativo perceptual do nadar (CAPn) e a propulsão na natação. 2005. 139 f. Tese (Doutorado em Educação Física) - Faculdade de Educação Física, Universidade Estadual de Campinas, Campinas, 2005.

CATTEAU, R., GAROFF, G. O ensino da natação. 3 ed. São Paulo: Manole, 1990.

CRUZ, G. de C. Formação continuada de professores de educação física em ambiente escolar inclusivo. 2005. Tese (Doutorado em Educação Física) - Faculdade de Educação Física, Universidade de Campinas, Campinas, 2005.

DAMASCENO, L. G. Natação, psicomotricidade e desenvolvimento. Campinas: Autores Associados, 1997.

DARIDO, S. C. Apresentação e análise das principais abordagens da educação física escolar. Revista Brasileira de Ciências do Esporte, v. 20, n. 1, p. 58-66, 1998.

DUARTE, E. Inclusão e acessibilidade: contribuições da educação física adaptada. Revista da Sobama. v. 10, n. 1, p. 27-30, dez. 2005. Suplemento.

ESCOBAR, M. O.; BURKHARDT, R. Natação para portadores de deficiência. Rio de Janeiro: Ao livro Técnico, 1985.

FERNANDES, J. R. P.; COSTA, P. H. L. da. Pedagogia da natação: um mergulho para além dos quatro estilos. Revista Brasileira de Educação Física e esporte, São Paulo, v. 20, n. 1, p. 5-14, jan./mar., 2006.

FERREIRA, M. E. C.; GUIMARÃES, M. Educação inclusiva. Rio de Janeiro: DP\&A, 2003.

FREIRE, M.; ANDRIES, O. J. O lúdico e a água. CONGRESSO BRASILEIRO DE CIÊNCIAS DO ESPORTE, 12., 2001. Caxambu. Anais... Caxambu: CBCE, 2001. 
FREIRE, M.; SCHWARTZ, G. Atividades lúdicas em meio aquático: aderência e motivação à prática regular de atividades físicas. Revista Digital, Buenos Aires, v. 10, n. 83, abr. $2005 \mathrm{a}$.

O papel do elemento lúdico nas aulas de natação. Revista Digital, Buenos Aires, v. 10 , n. 86 , jul. 2005 b.

. Afetividade nas aulas de natação: mediação do professor. Revista Digital, Buenos Aires, v. 10, n. 94, mar. 2006.

FREIDENHEIM, A. M.; GAMA, R. I. R. B.; CARRACEDO, V. A. Fundamentos para a elaboração de programas de ensino do nadar para crianças. Revista Mackenzie de Educação Física e Esporte, v. 2, n. 2, p. 61-69, 2003.

FUGITA, M. Percepção do seu próprio nadar: nadadores deficientes visuais e videntes.

Revista Mackenzie de Educação Física, v. 2, n. 2, p. 71-83, 2003.

IBGE. Pesquisa Nacional por Amostra de Domicílio. Rio de Janeiro, 2000.

LUZ, L. M. R. da. A natação, o cego e o deficiente visual: a inclusão e suas implicações no desporto de rendimento. 2003. Dissertação (Mestrado em Educação Física) - Universidade Estadual de Campinas, Faculdade de Educação, Campinas, 2003.

MACHADO, D. C. Metodologia da natação. 2. ed. São Paulo: EPU, 1978.

MACIEL, Rosana M. et al. A natação e o portador de paralisia cerebral. Revista da Sobama, v. 8, n. 1, p. 37, dez. 2003. Suplemento.

MENESCAL, A. A criança portadora de deficiência visual usando o seu corpo e descobrindo o mundo. In: BRASIL. Ministério do Esporte e Turismo, Lazer. Atividades físicas e esportivas para portadores de deficiência. Brasília, DF, 2001.

MOISÉS, M. P. Ensino da natação: expectativas dos pais de alunos. Revista Mackenzie de Educação Física e Esporte, São Paulo, v. 5, n. 2, p. 65-74, 2005.

OLIVEIRA, V. M. O jogo e a brincadeira como estratégia metodológica em educação física para pessoas portadoras de deficiência mental: algumas considerações. In: FREITAS, P. S. Educação Física e esporte para deficientes: coletânea. Uberlândia: UFU, 2000.

PENAFORT, J. D. A integração do esporte adaptado com o esporte convencional a partir da inserção de provas adaptadas: um estudo de caso. 2001. Dissertação (Mestrado em Educação Física) - Faculdade de Educação Física, Universidade Estadual de Campinas, Campinas, 2001.

PEREIRA, M. D. O mundo fantasia e o meio líquido: o processo de ensino aprendizagem da natação e sua relação com o faz-de-conta, através de aulas temáticas. 2001. (Mestrado em Educação Física) - Faculdade de Educação Física, Universidade Estadual de Campinas, Campinas, 2001.

QUEIROZ, C. A. Recreação aquática. Rio de Janeiro: SPRINT, 1998.

SANTIAGO, D. R.; TAHARA, A. K. Lazer, lúdico e atividades aquáticas: uma relação de sucesso. Movimento e percepção, Espírito Santo do Pinhal, v. 7, n. 10, p. 105-115, jan./ jun. 2007. 
SANTOS, C. A. Natação-ensino e aprendizagem. Rio de Janeiro: Sprint, 1996.

SANTOS, A., et al. Lazer, esporte, jogo e trabalho: uma relação com a deficiência. Diálogos possíveis, Salvador, v. 5, n. 1, jan./jun. 2006.

SOUZA, J. V. de. Atividades aquáticas para crianças portadoras de deficiências: uma proposta ao meio líquido. 1999. Dissertação (Mestrado em Educação Física) - Faculdade de Educação Física, Universidade Estadual de Campinas, Campinas, 1999.

SOUZA, O. M. et al. Natação para pessoas com deficiência: uma experiência no NEFEA UEFS. Revista da Sobama, v. 10, n. 1, dez. 2005. Suplemento.

SOUZA, P. A. O esporte na paraplegia e tetraplegia. Rio de Janeiro: Guanabara Koogan, 1994.

SOUZA, W. C. de. A inclusão do educando com deficiência na escola pública municipal da cidade de Goiânia: o discurso dos professores de Educação Física. 2003. Dissertação (Mestrado em Educação Física) - Faculdade de Educação Física, Universidade Estadual de Campinas, Campinas. 2003.

TSUTSUMI, Olívia et. al. Os benefícios da natação adaptada em indivíduos com lesões neurológicas. Revista Neurociências, v. 12, n. 2, abr./jun. 2004.

VELASCO, C. Natação segundo a psicomotricidade. 2. ed. Rio de Janeiro: Sprint, 1997.

XAVIER FILHO, E.; MANOLE, E. J. Desenvolvimento do comportamento motor aquático: implicações para a pedagogia da natação. Revista Brasileira Ciência e Movimento, v. 10, n. 2, p. 85-94, 2002.

ZULIETTI, L. F.; SOUSA, I. L. R. A Aprendizagem da natação do nascimento aos 6 anos: fases do desenvolvimento. Revista Uni Vap, v. 9, n. 17, 2002. 


\section{A FORMAÇÃO CONTINUADA DO PROFESSOR DE ARTE NA PERSPECTIVA DE UMA EDUCAÇÃO INCLUSIVA}

Roberto Sanches Rabêllo

\section{INTRODUÇÃO}

Este texto foi produzido com o objetivo de refletir sobre a formação continuada do professor de arte na perspectiva da inclusão do aluno com deficiência visual e sobre a necessidade de inserção desse aluno no mundo da arte, sem desprezo aos aspectos sensoriais e sensíveis envolvidos em tal formação.

Entende-se por educação inclusiva o acesso igualitário aos bens educacionais, na rede regular de ensino, para todas as pessoas, incluindo as que possuem deficiência visual. Diante disso, cabe discutir uma proposta para o ensino de arte que garanta tanto a socialização dos alunos, como a aprendizagem e o desenvolvimento das suas potencialidades. Como os professores de arte atuam nesse sentido? E como atender às suas próprias necessidades de formação continuada, considerando os novos paradigmas educacionais?

Para responder a essas questões buscou-se o apoio dos professores, desenvolvendo uma pesquisa-ação, ${ }^{1}$ definida como uma metodologia voltada para a

\footnotetext{
${ }^{1}$ Trata-se de uma pesquisa desenvolvida na FACED/UFBA, intitulada Ensino de arte e atendimento ao aluno com deficiência visual na rede pública estadual de ensino, que tem o apoio do PIBIC, por meio da orientanda Eliane de Sousa Nascimento. Foram realizadas duas etapas da pesquisa, envolvendo um diagnóstico elaborado a partir de questionário aplicado com coordenadores de oito escolas em Salvador, e a análise de entrevistas realizadas com oito professores de arte. A terceira etapa, a ser iniciada, visa o retorno dos dados e a formação continuada do professor de arte.
} 
ação coletiva e intervenção concreta na realidade investigada. Isso significa promover, na etapa final da investigação, a interação entre os atores sociais implicados na pesquisa e o compartilhamento das dificuldades e experiências, visando o crescimento profissional.

A formação inicial do professor nos moldes atuais geralmente não considera as necessidades emergentes do sistema de ensino. Com a democratização do ensino e com a proposta de inclusão de todos os alunos em classe regular, as escolas estão atendendo uma grande diversidade de pessoas de classes sociais, etnias e necessidades educacionais diferenciadas, embora os professores reclamem da ausência de conteúdos na formação inicial e continuada que dêem conta dessas demandas.

$\mathrm{O}$ assunto do texto relevante, considerando, sobretudo, que o problema central diz respeito à necessidade de uma formação continuada que possa favorecer a melhoria dos relacionamentos não apenas entre professores e alunos e entre alunos videntes e alunos com deficiência visual, mas ao próprio relacionamento do professor consigo mesmo.

No presente artigo, enfoca-se num primeiro momento as concepções de ensino de arte no Brasil. Num segundo momento, aborda-se o paradigma da inclusão, discutindo a questão da dificuldade na implementação de propostas. Em seguida, são descritos alguns achados da pesquisa, analisando aspectos que dificultam o trabalho do professor e o relacionamento no contexto escolar. A partir dessas considerações é que proponho a questão da formação continuada do professor de arte na perspectiva de uma educação inclusiva, alertando para a necessidade de envolver conteúdos e práticas relacionadas com a diversidade cultural e com os diferentes tipos de deficiência.

\section{CONCEPÇÕES DE ENSINO DE ARTE}

São muitas as concepções de ensino de arte presentes na contemporaneidade, e estas, segundo Barbosa (2004) dependem da ênfase que se dá às funções da arte na educação. Dentre as diversas concepções podemos destacar três que podem ajudar na compreensão da realidade encontrada nas escolas pesquisadas no município de Salvador: a de preparação para o trabalho, a de auto-expressão criadora e a de arte como desenvolvimento da cognição.

No Brasil, a ideia de preparação para o trabalho surge ao final do século XIX e enfatiza uma função apontada pela revolução industrial, relacionada com a necessidade de desenvolver habilidades úteis para as diversas profissões e 
flexibilizar o indivíduo para ser capaz de desempenhar diferentes tarefas na construção civil e na produção industrial. A arte passa a ser entendida como desenho geométrico, enfatizando não os objetivos artísticos, mas sim, os conceitos geométricos e a perspectiva linear.

A ideia da arte na escola como autoexpressão criadora surge a partir da década de 1920, em contraposição ao ensino tradicional, sendo influenciada pelas concepções de Viktor Lowenfeld e Herbert Read. Conforme Barbosa (2004), a arte é interpretada como algo emocional e não mental, como atividade concreta e não abstrata, como trabalho das mãos e não da cabeça. A ideia de que a arte na educação tem a finalidade principal de permitir que a criança expresse seus sentimentos, termina levando a ideia de que a arte não é ensinada, mas expressada, como se os processos intelectuais e emocionais se mobilizassem automaticamente na produção artística.

O movimento de Arte-Educação como cognição se impõe no Brasil a partir dos anos 1980 e enfatiza a necessidade de fazer arte, mas também de ensinar a ver e refletir sobre arte. Este movimento luta pelo reconhecimento da arte como disciplina que tem objeto e conteúdo próprios, relacionados com o pensamento artístico e com a sensibilidade e consciência estética.

Segundo os Parâmetros Curriculares Nacionais (PCNs), "o movimento Arte-Educação permitiu que se ampliassem as discussões sobre valorização e o aprimoramento do professor, que reconhecia o seu isolamento dentro da escola e a insuficiência de conhecimentos e competência na área." (BRASIL, 1998, p. 30).

A tendência da arte como cognição toma corpo ao longo do tempo, sobretudo com a lei 9.394/96, que institui a obrigatoriedade do ensino de arte na educação básica, sendo adotada inclusive nos PCNs - Arte, que reconhece o significado de não somente aprender a produzir e apreciar arte, mas também perceber sua realidade cotidiana mais vivamente, interagindo no contexto sociocultural: "A arte solicita a visão, a escuta e os demais sentidos como portas de entrada para uma compreensão mais significativa das questões sociais." (BRASIL, 1998, p. 20).

No início do século XXI ainda encontramos concepções de arte, como veremos mais adiante, que não atendem às novas demandas advindas da democratização do ensino. Os professores continuam desvalorizados e reivindicando novas competências, que permitam dar conta do trabalho com estudantes que possuem deficiências de ordem física, sensorial, mental, e que por força da lei 9.394/96 passaram a frequentar o ensino regular em classe comum. 
Portanto, antes de falar a respeito da situação dos professores de arte que pesquisamos em Salvador, vamos nos reportar a algumas questões a respeito do paradigma da inclusão das pessoas com deficiência na escola regular e da dificuldade de implementação desse modelo nos dias atuais.

\section{O PARADIGMA DA EDUCAÇÃO INCLUSIVA E A REALIDADE DA INCLUSÃO}

A Convenção Interamericana para a Eliminação de Todas as Formas de Discriminação contra as Pessoas Portadoras de Deficiência define deficiência como uma restrição física, mental ou sensorial, de natureza permanente ou transitória, que limita a capacidade de exercer uma ou mais atividades essenciais da vida diária, causada ou agravada pelo ambiente econômico e social. Vemos, portanto, que se trata de um limite e não de uma impossibilidade.

No Brasil, a Constituição Federal e a lei 9.394/96 garantem às pessoas com deficiência o atendimento educacional "preferencialmente na rede regular de ensino" (BRASIL, 1996). Antes da lei, a perspectiva era de "integração" do aluno na escola desde que este pudesse se adaptar sem que houvesse mudança da escola. No paradigma da inclusão é reconhecida a necessidade de uma política educacional mais democrática, envolvendo a reformulação dos currículos, das formas de avaliação e da formação dos professores. Portanto, a noção de inclusão não é incompatível com a de integração, porém institui a inserção do aluno com deficiência de forma mais radical; também não é incompatível com um ensino especializado no aluno.

A proposta de inclusão advoga a colocação de todos os estudantes na classe comum da escola próxima à sua residência, considerando a possibilidade de serviços, de suportes, ou mesmo ambientes diferenciados, tais como sala de recursos, classes especiais ou escolas especiais.

Ao discutir o significado da inclusão do aluno em classe regular Marchesi e Martín (1995) referem-se a exposições desajustadas que colocam a integração como um fim em si mesma, visando apenas que os alunos fiquem juntos em uma mesma escola, enquanto outros autores insistem em que "o objetivo principal de toda esta dinâmica não é a integração, mas, sim a educação dos alunos com necessidades educacionais especiais" (MARCHESI; MARTÍN, 1995, p. 15). Os autores dizem também que o sistema educacional como um todo é que deve assumir a responsabilidade diante desse objetivo, e não apenas os professores especialistas. O que vem acontecendo em nossas escolas é que muitas vezes o 
professor da classe regular delega ao professor especializado o atendimento educacional ao deficiente visual. Contudo, para que possamos atingir os objetivos educacionais é importante não minimizar a importância dos fatores ambientais, considerando a integração como objetivo menor.

O objetivo da inclusão é de socialização e educação efetiva de todos os alunos. Em outras palavras significa extensão de oportunidades iguais para todos, permitindo que todos possam fazer amizades, mudando o pensamento estereotipado sobre as incapacidades, fortalecendo em todos as habilidades de socialização; significa também auxiliar o aluno a dominar habilidades e conhecimentos necessários para a vida futura, tanto dentro quanto fora da escola, o que inclui o conhecimento em arte. A inclusão visa então oportunizar a aprendizagem social e o desempenho acadêmico bem-sucedido de todos os alunos.

Mas as evidências empíricas sustentam ou não a inclusão? Glat (1998) afirma que o problema da inclusão é de natureza pragmática e operacional e não teórica e ideológica. Sem uma mudança estrutural do sistema educacional brasileiro a inclusão de alunos com deficiência nunca será concretizada. A inclusão total é uma utopia que tem seu valor simbólico, representando um investimento afetivo em função de algo que almejamos: uma sociedade inclusiva. Mas, argumenta a autora que, da mesma forma que o socialismo não deu certo, a proposta de educação inclusiva pode não dar, pois os programas não foram bem idealizados, precisamos investir na aplicação prática, em pesquisa e experimentação de formas alternativas de adaptação e implementação, considerando os diferentes contextos.

\section{A PESQUISA EMPÍRICA E A REALIDADE DO PROFESSOR}

Na pesquisa que realizamos nas escolas estaduais a partir de 2003, encontramos uma realidade caótica. O professor, na maioria das vezes não dispõe sequer de uma sala ambiente, dotada de mesas para trabalhos coletivos, de pia para lavar material e armários para guardá-los. Constatamos que diante das condições materiais fica difícil falar em inclusão.

De fato, quando esbarramos na realidade de 40 alunos em sala de aula pequena, planejamento individualizado para cada aluno, por exemplo, pode parecer algo estapafúrdio. Neste caso, o atendimento individualizado para a criança com deficiência significa perda de controle e desgaste no trabalho do professor, por mais competente que ele seja. 
As condições humanas se deterioram mais ainda quando pensamos no apoio técnico dado ao professor. O Centro de Apoio Pedagógico ao Deficiente Visual carece de profissionais em número suficiente para o atendimento aos alunos e professores das escolas da rede. Constatamos nesse particular, que a maioria dos professores não se relacionam com o professor da sala de recursos que dão apoio ao aluno com deficiência visual.

A ausência de relacionamento não se justifica, considerando-se que o professor de arte não tem maiores informações a respeito da deficiência visual e os professores especialistas, que detêm esta informação, não dominam o campo da arte e os processos de sensibilização que poderiam ajudar na melhoria dos relacionamentos.

Sabemos que a maneira como o professor dinamiza a relação entre alunos em sala de aula passa por um trabalho de quebra de barreiras atitudinais, que envolve a consciência/vivência de princípios, tão divulgados em documentos internacionais (Salamaca/Guatemala), como os de igualdade de oportunidades, de respeito à diversidade, de solidariedade e acolhimento, de cooperativismo, de pedagogia centrada na criança, de individualização do ensino, de parceria: pais e comunidade, de educação como direito de todos.

A situação de ensino cooperativa propicia uma interação construtiva quando o aluno se preocupa com o outro. Essa preocupação com o outro leva o aluno que enxerga não apenas a desenvolver aspectos de solidariedade, mas também desenvolve os aspectos cognitivos, quando permite que o aluno busque estratégias para ajudar o colega com deficiência.

Cabe ao professor propiciar situações de ensino que permitam a interação entre deficientes visuais e videntes, o que contribui para a entrada do deficiente visual nas experiências normais de vida. Mas o fato é que habilidades artísticas, de recreação e de lazer não estão sendo desenvolvidas nas escolas. E esse pedaço que fica faltando é fundamental para a inserção social do deficiente visual fora da escola. Caso contrário, continuarão invisíveis ou realizando apenas o trajeto de casa para a escola e daí para as instituições especializadas ou associações de cegos.

Entendemos que as pessoas cegas necessitam de um cuidado maior para o desenvolvimento de habilidades básicas na área social e de comunicação, que normalmente são dadas em instituições especializadas. Nas escolas comuns que pesquisamos, percebemos que o ensino de arte voltado para o esquema de atelier muitas vezes não dinamiza a relação entre os alunos e que o ensino cooperativo exige materiais grandes e inacessíveis ao professor da escola pública. 
Ademais, o aluno cego tem menores oportunidades de contato com as chamadas artes visuais que os alunos que enxergam. Apesar da obrigatoriedade da arte e da matricula do aluno em classe regular, a vivência artística de pessoas cegas congênitas geralmente acontecem em instituições especializadas, limitando-se geralmente à modalidade musical.

O professor de arte quando desconhece o potencial das pessoas cegas não conseguem separar a produção (fazer artístico) da leitura (apreciação) e muito menos os limites e potencialidades para cada uma dessas formas de conhecimento em arte. Os conteúdos de desenho geométrico ou de história da arte predominam, mostrando o apego a concepções que trazem em seu bojo a preocupação com a preparação para o trabalho ou a ênfase cognitivista, em detrimento aos aspectos sensoriais e sensíveis.

Por outro lado, não podemos esquecer que a dimensão estética do homem radica-se prioritariamente no intelecto e a cegueira não é um entrave intransponível. De fato, não é apenas com a mão que desenhamos, mas com a inteligência. Sabemos de uma pessoa tetraplégica que desenha divinamente bem no computador, pois embora tenha estourado a medula, conseguiu conservar a habilidade de desenhar adquirida antes do acidente, utilizando os resquícios de movimento para elaborações artísticas com o mouse adaptado.

O cego é um ser humano que possui a audição, que permite o desenvolvimento da linguagem oral, recurso básico para a comunicação e desenvolvimento do pensamento e fundamental para o aprendizado de qualquer disciplina; possui o tato mais desenvolvido que os outros animais, que somada com a capacidade de raciocínio e com a dimensão simbólica permite o acesso à linguagem escrita. Isso tudo sem falar na dimensão lúdica e estética, na capacidade de criar e apreciar por meio da audição, do tato e do polegar opositor que também o define como humano.

Portanto, a pessoa cega tem condições de ser atendida conforme os novos paradigmas do ensino de arte. Contudo, o perigo desses paradigmas está no reforço ao cognitivismo característico de nossas escolas. Escolas do ensino médio, quando incluem a arte no currículo, contemplam apenas uma hora semanal. Com essa carga horária e diante da carência material o professor se restringe aos conteúdos de história da arte, que por si só não garante a construção do conhecimento em arte. 


\section{CONCLUSÃO}

Os novos paradigmas educacionais apontam para uma formação continuada de professores que atendam aos requisitos de uma educação estética tanto para os alunos como para os seus professores.

Como vimos, as concepções do ensino de arte cognitivistas trazem o perigo do desleixo em relação a uma educação da sensibilidade. No caso da pessoa com deficiência visual, não se trabalha adequadamente a sensibilidade do indivíduo que, bem o sabemos, vai além da preocupação com os aspectos sensoriais, sem dúvida fundamentais para um fazer artístico e para a percepção da forma. A sensibilidade se manifesta no corpo por meio dos sentidos e os sentidos que uma pessoa cega dispõe leva-a a perceber as modificações do meio externo ou interno e reagir a elas de alguma maneira. Mas a faculdade de sentir não se limita aos sentidos, pois todo ser humano possui emoções, sentimentos, que podem ser expressos e que revelam formas de sentir, formas de experimentar sentimentos de humanidade.

As pessoas cegas têm a possibilidade de ser sensível aos elementos das diversas formas artísticas, e estes elementos são capazes de despertar emoções as mais inusitadas. Trabalhar a sensibilidade do sujeito significa, portanto, cuidar $\mathrm{da}$ afetividade, com o seu desejo, com a sua vontade, com os seus diversos canais perceptivos, com a sua vitalidade, com a sua alma. Não se trata, portanto, do sensorial, do cérebro ou das sensações apenas, trata-se de pessoas inteiras, que têm a faculdade amar e de ser amado, de sentir paixão, de ter afeição, ternura, amizade, carinho, simpatia, prazer.

A arte nas suas diversas modalidades tem o poder de tornar o indivíduo cada vez mais sensível, e dessa forma, o mundo torna-se mais enriquecido, pois pode ser apreendido de forma qualitativamente mais interessante e pode ser enriquecido com a qualidade humana de um sujeito transformado. Educar é isso, sensibilizar a pessoa, tornando-a mais humana. O que colocamos para uma pessoa cega pode ser estendido para a educação de qualquer pessoa. A diferença, é que uma criança cega, por exemplo, não tem a mesma facilidade de exploração dos canais sensoriais que a criança vidente. Se a mãe ou a figura de apego não estimular adequadamente, a criança decerto não vai engatinhar, nem correr atrás dos brinquedos.

As proposições do ensino de arte deveriam também aproximar os alunos das realizações culturais da sua comunidade, partindo daí para a compreensão de outras culturas. A aproximação primeira é com a forma de sentir de sua 
própria comunidade, que no caso da Bahia, tem um componente afro-descendente acentuado.

No aspecto da formação continuada, constatamos a carência de contato dos professores com investigações sobre experiências de inclusão bem sucedidas em escolas públicas e privadas no Brasil, que possam oferecer uma referência, sobretudo em relação ao que fazer para que a inclusão ocorra em moldes satisfatórios.

Percebemos também a precariedade na orientação dada pelo professor de arte à educação do deficiente visual, e a ausência de uma forma continuada que ofereça ao próprio professor a vivência, a reflexão e a troca de experiências estéticas.

\section{REFERÊNCIAS}

BARBOSA, Ana Mae. Visões de arte-educação. Revista do Instituto de Arte das Américas, v. 1 , n. 2, p. 8-13, jul./dez. 2004..

BRASIL. Secretaria de Educação Fundamental. Parâmetros Nacionais Curriculares. Arte. Brasília, DF, 1998.

BRASIL. Lei n. 9.394, de 20 de dezembro de 1996. Estabelece as diretrizes e bases da educação nacional. Brasília, 1996. Disponível em: < http://www.planalto.gov.br/ ccivil_03/ Leis/ L9394.htm\#art92>. Acesso em: 15 set. 2007.

GLAT, Rosana. Inclusão total: mais uma utopia? Revista Integração, Brasília, v. 8, n. 20, 1998.

MARCHESI, Álvaro; MARTIN, Elena. Da terminologia do distúrbio às necessidades educacionais especiais. In: COLL, Cesar et al. Desenvolvimento psicológico e educação: necessidades educativas especiais e aprendizagem escolar. Porto Alegre: Artes Médicas, 1995. p. 7-23.

THIOLLENT, Michel. Metodologia da pesquisa-ação. São Paulo: Cortez, 1998. 



\section{SOBRE OS AUTORES}

\section{Admilson Santos}

Doutor em Educação pela Universidade Federal da Bahia, Professor da Faculdade Social da Bahia, Professor Assistente da Universidade Federal da Bahia e Coordenador do Colegiado de Educação Física da Universidade Estadual de Feira de Santana.

\section{Afonso Henriques}

Doutor em Didática da Matemática pela Universidade Joseph Fourier - Grenoble - França e Professor Adjunto B da Universidade Estadual de Santa Cruz.

\section{Aida Carvalho Vita}

Mestre em Educação pela Universidade Federal da Bahia e Professora Auxiliar da Universidade Estadual de Santa Cruz.

\section{Alessandra Barros}

Doutora em Ciências Sociais pela Universidade Federal da Bahia e Professora Adjunto da Universidade Federal da Bahia.

\section{Amanda Ribeiro Botelho}

Pedagoga e Mestranda em Educação da Universidade Federal da Bahia.

\section{Andréa Direne da Matta Castro}

Mestre em Políticas Públicas, Gestão do Conhecimento e Desenvolvimento Regional pela Universidade do Estado da Bahia e Coordenadora Administrativa do Núcleo de Tecnologia Educacional.

\section{Antonilma Santos Almeida Castro}

Mestre em Educação Especial pela Universidade Estadual de Feira de Santana e Professora Assistente da Universidade Estadual de Feira de Santana e da Universidade do Estado da Bahia.

\section{Antônio Fernando Santos}

Mestre em Educação pela Universidade Vale do Rio Verde e Professor da Graduação em Educação Física da Fundação Helena Antipoff/MG.

\section{Argemiro de Paula Garcia Filho}

Geólogo e Diretor da Associação de Familiares e Amigos da Gente Autista (Afaga) e da Associação Brasileira para a Ação por Direitos da Pessoa com Autismo (Abraça). 


\section{Carlos Alberto Fonseca Jardim Vianna}

Mestrando em Ciências pela Universidade Federal Rural do Rio de Janeiro.

Célia Verônica Paranhos de Jesus Portela

Pedagoga e Professora da Rede Municipal de Ensino / Santo Amaro-BA.

\section{Chrystiane Vasconcelos Andrade Toscano}

Mestre em Educação Especial pelo Instituto Superior Pedagógico Enrique José Varona e Professora Titular da Universidade Tiradentes.

\section{Cláudia Paranhos de Jesus Portela}

Mestre em Educação Especial pela Universidade Estadual de Feira de Santana, Professora da Universidade do Estado da Bahia e Coordenadora Pedagógica da Secretaria de Educação.

\section{Cleverson Suzart}

Doutor em Educação pela Universidade Federal da Bahia e Professor Adjunto I da Universidade Federal da Bahia.

\section{Cristiane Teixeira Sampaio}

Mestre em Psicologia pela Universidade Federal da Bahia e Psicóloga do Centro Estadual de Prevenção e Reabilitação das Deficiências.

\section{Daniela Fernanda da Hora Correia}

Especialista em Desigualdade Racial e Educação pelo Centro de Estudos Afro Orientais/Brasil e Coordenadora do Ensino Fundamental I da Secretaria Municipal de Educação e Cultura de Salvador.

\section{Diana Maria Pereira Cardoso}

Mestre em Educação pela Universidade Federal da Bahia e Professora da Secretaria Municipal da Educação e Cultura de Salvador/BA.

\section{Elaine Pereira Terrassi}

Mestre em Educação Especial pela Universidade Federal de São Carlos e Professora Titular da Universidade Tiradentes.

\section{Eliane Sousa Nascimento}

Mestranda em Educação pela Faculdade de Educação da Universidade Federal da Bahia.

\section{Elias Souza dos Santos}

Especialista em Arte Educação pela Faculdade São Luís de França e Professor da Escola e Oficina de Arte Valdice Teles.

\section{Érica Bastos da Silva}

Pedagoga e Mestranda em Educação pela Universidade Federal da Bahia. Desenvolve pesquisas sobre Educação e Linguagem na Alfabetização de Jovens e Adultos.

Evanir Abenhaim

Psicóloga e Mestre em Educação pela Universidade Federal da Bahia. 


\section{Fábio Zoboli}

Doutor em Educação pela Universidade Federal da Bahia e Professor do Ensino Fundamental da Secretaria de Educação do Estado de Santa Catarina.

\section{Félix Díaz Rodríguez}

Doutor em Ciências Pedagógicas pelo Instituto Central de Ciências Pedagógicas Del Mined, Cuba e Professor Adjunto da Universidade Federal da Bahia.

\section{Fernanda Ma Gonçalves Almeida}

Graduada em Direito, Mestre e Doutora em Ciências Sociais para a Educação pela Universidade Federal da Bahia.

\section{Fernanda Nunes Macedo}

Graduanda em Psicologia da Universidade Tiradentes.

\section{Gillianderson Freitas Ribeiro}

Graduado em Licenciatura em Matemática pela Universidade Estadual de Feira de Santana.

\section{Gilmar Mercês de Jesus}

Mestre em Saúde Coletiva pela Universidade Estadual de Feira de Santana e Professor Auxiliar da Universidade Estadual de Feira de Santana.

\section{Iara Rosa Farias}

Doutora em Linguística pela Universidade de São Paulo, Pós-Doutora pela Universidade Federal do Rio de Janeiro e Professora Adjunto da Universidade Federal de São Paulo - Campus Guarulhos.

\section{Irene Maurício Cazorla}

Doutora em Educação pela Universidade Estadual de Campinas, Pós-Doutora pela Pontifícia Universidade Católica de São Paulo e Professora Titular da Universidade Estadual de Santa Cruz.

\section{Jamine Barros Oliveira}

Mestranda em Educação pela Universidade Federal da Bahia, Diretora Técnica de Planejamento e Avaliação da Secretaria Municipal de Saúde de Itapetinga e Professora Efetiva da Universidade Estadual do Sudoeste da Bahia.

\section{João Danilo Batista de Oliveira}

Doutorando em Educação pela Universidade Federal da Bahia na linha de Educação, Arte e Diversidade e Professor da Universidade Estadual de Feira de Santana e da Faculdade Social da Bahia.

\section{Leliana de Sousa Gauthier}

Doutora em Educação pela Université Paris VIII, França e Professora Adjunto da Universidade do Estado da Bahia.

\section{Lívia Menezes da Paz}

Mestre em Estatística pela Universidade Federal de Minas Gerais e Professora Assistente da Universidade Federal do Recôncavo da Bahia. 


\section{Marcelo Torreão Sá}

Mestrando do Programa em Educação e Contemporaneidade e Professor Visitante da Universidade do Estado da Bahia - Campus XI.

\section{Maria Celeste Ramos da Silva}

Mestre em Educação pela Universidade Federal da Bahia e Docente de Classe Hospitalar das Obras Sociais Irmã Dulce - Hospital da Criança.

\section{Mariene Martins Maciel}

Especialista em Historiografia Brasileira e Metodologia da História pela Universidade Estadual de Feira de Santana.

\section{Marilda Carneiro Santos}

Mestre em Educação Especial pelo Centro de Referência Latinoamericano para a Educação Especial e Professora Adjunto da Universidade Estadual de Feira de Santana.

\section{Marilda Castelar}

Doutora em Psicologia Social pela Pontifícia Universidade Católica de São Paulo, Professora Adjunto da Escola Bahiana de Medicina e Saúde Pública e Professora da Faculdade Social e da Faculdade de Tecnologia e Ciências.

\section{Mary Arapiraca}

Doutora em Educação pela Universidade Federal da Bahia e Professora Associada da Universidade Federal da Bahia.

\section{Miguel Angel Garcia Bordas}

Doutor em Filosofia pelo Universidad Complutense de Madrid, Espanha, Pós-Doutor pelo Universidad Autonoma de Barcelona, Espanha e Professor Associado da Universidade Federal da Bahia.

\section{Miralva Jesus dos Santos}

Mestre em Educação e Professora da Faculdade Regional da Bahia.

\section{Nayara Alves de Sousa}

Mestre em Educação pela Faculdade de Educação da Universidade Federal da Bahia e Professora Assistente da Universidade Estadual do Sudoeste da Bahia - campus Universitário de Jequié.

\section{Nelma de Cássia Silva Sandes Galvão}

Psicóloga, Especialista em Linguagem, Mestre e Doutoranda em Educação pela Universidade Federal da Bahia. Professora Assistente da Faculdade de Educação da Universidade Federal da Bahia.

\section{Nicoleta Mendes}

Mestre em Educação pela Universidade Estadual de Santa Cruz/Universidade Federal da Bahia e Professora Assistente da Universidade do Estado da Bahia. 


\section{Patrícia Carla da Hora Correia}

Mestre em Educação Especial pelo Centro de Referência Latinoamericano de Educação Especial, Colaboradora do Instituto Adventista do Nordeste e Professora Assistente da Universidade do Estado da Bahia.

\section{Renata Barbosa Gonçalves}

Graduada em Ciências da Natureza (Licenciatura em Física) pelo Instituto Federal de Educação, Ciência e Tecnologia Fluminense e Estagiária do Instituto Benjamin Constant.

\section{Renato Izidoro da Silva}

Doutor em Educação pela Universidade Federal da Bahia e Professor da Universidade Regional da Bahia.

\section{Rita de Cácia S. Souza}

Doutora em Educação pela Faculdade de Educação da Universidade Federal da Bahia, Professora da Rede Pública Estadual em Aracaju-Sergipe e Membro da Associação Brasileira de Pesquisadores em Educação Especial.

\section{Roberto Sanches Rabêllo}

Doutor em Educação pela Universidade de São Paulo e Professor Adjunto da Universidade Federal da Bahia.

\section{Sandra Regina Rosa Farias}

Mestre em Saúde Coletiva pela Universidade Estadual de Feira de Santana e Professora da Universidade Estadual de Feira de Santana.

\section{Sheila Correia de Araújo}

Doutoranda em Educação da Faculdade de Educação da Universidade Federal da Bahia, Professora Titular da Escola Bahiana de Medicina e Saúde Pública e Terapeuta Ocupacional do Centro de Intervenção Precoce do Instituto de Cegos da Bahia.

\section{Silvana Correia Silva}

Graduada em Psicologia pela Fundação Bahiana para o desenvolvimento das Ciências (FBDC) e Psicóloga da FBDC.

\section{Sirley Brandão dos Santos}

Mestre em Engenharia e Ciências dos Materiais pela Universidade Estadual do Norte Fluminense Darcy Ribeiro e Professor Efetivo do Instituto Federal de Educação, Ciência e Tecnologia Fluminense.

\section{Sônia Maria Rocha Sampaio}

Doutora em Educação pela Universidade Federal da Bahia, Pós-Doutora pelo Universite de Paris VIII, França e Professora Associada II da Universidade Federal da Bahia.

\section{Susana Couto Pimentel}

Doutora em Educação pela Universidade Federal da Bahia e Professora Adjunto da Universidade Federal do Recôncavo da Bahia. 


\section{Suzana Alves Nogueira}

Especialista em Educação Especial pela Universidade Estadual de Feira de Santana e Coordenadora do Setor de Esporte da Associação de Pais e Amigos dos Excepcionais - Monção.

\section{Tânia de Souza Lima}

Graduada em Licenciatura em Letras com Espanhol pela Universidade Estadual de Feira de Santana e Professora da Universidade Federal da Bahia.

\section{Telma Brito Rocha}

Mestre em Educação pela Universidade Federal da Bahia e Professora da Universidade do Estado da Bahia.

\section{Teófilo Alves Galvão Filho}

Doutor em Educação pela Universidade Federal da Bahia com

atuação em Tecnologia Assistiva e Membro Permanente do Comitê de Ajuda Técnica da Secretaria Especial dos Direitos Humanos da Presidência da República.

\section{Theresinha Guimarães Miranda}

Doutora em Educação pela Universidade de São Paulo, Presidente do Conselho Estadual de Educação da Bahia e Professora Associada da Universidade Federal da Bahia. 



\section{Colofão}

\begin{tabular}{r|l} 
Formato & \multicolumn{1}{c}{$17 \times 24 \mathrm{~cm}$} \\
Tipologia & AmeriGarmnd BT \\
Papel & $\begin{array}{l}75 \mathrm{~g} / \mathrm{m}^{2} \text { (miolo) } \\
\text { Cartão Supremo } 250 \mathrm{~g} / \mathrm{m}^{2} \text { (capa) }\end{array}$ \\
Impressão & Setor de Reprografia da EDUFBA \\
Capa e Acabamento & Gráfica Cian \\
Tiragem & 500 exemplares
\end{tabular}

